

\section{DISCLAIMER}

This report was prepared as an account of work sponsored by an agency of the United States Government. Neither the United States Government nor any agency Thereof, nor any of their employees, makes any warranty, express or implied, or assumes any legal liability or responsibility for the accuracy, completeness, or usefulness of any information, apparatus, product, or process disclosed, or represents that its use would not infringe privately owned rights. Reference herein to any specific commercial product, process, or service by trade name, trademark, manufacturer, or otherwise does not necessarily constitute or imply its endorsement, recommendation, or favoring by the United States Government or any agency thereof. The views and opinions of authors expressed herein do not necessarily state or reflect those of the United States Government or any agency thereof. 


\section{DISCLAIMER}

Portions of this document may be illegible in electronic image products. Images are produced from the best available original document. 
Printed in the United States of America

Available from

National Technical Information Service

U.S. Department of Commerce

5285 Port Royal Road

Springfield, VA 22161

NTIS Price Codes: Printed Copy A08

Microfiche A01

\section{DISCLAIMER}

This book was prepared as an account of work sponsored by an agency of the I Initer States Government. Neither the United States Government nor any agency thereof, nor any of their employees, makes any warranty, express or implied, or assumes any legal liability or responsibility for the accuracy, completeness, or usefulness of any information, apparatus, product or process disclosed, or represents that its use would not infringe privately owned rights. References herein to any specific commercial product, process, or service by trade name, trademark, manufacturer, or otherwise, does not necessarily constitute or imply its endorsemenl, recommendation, or favoring by the United States Government or any agency thereof. The views and opinions of authors expressed herein do not necessarily state or reflect those of the United States Government or any agency thereof. 


\title{
AN ASSESSMENT OF SELECTED CONSERVATION MEASURES FOR HIGH-TEMPERATURE PROCESS INDUSTRIES
}

\author{
Prepared for \\ OFFICE OF INDUSTRIAL PROGRAMS \\ DIVISION OF INDUSTRIAL ENERGY CONSERVATION \\ DEPARTMENT OF ENERGY \\ Washington, D.C. 20585 \\ by \\ Dr. C.L. Kusik (Project Manager) \\ Dr. Krishna Parameswaran \\ Dr. Ravindra Nadkarni \\ J. Kevin O'Neill \\ Subhash Malhotra , \\ Richard Hyde , \\ David Kinneberg , \\ Lee Fox . \\ Michael Rossetti
}

Contract No. EC-77-C-03-1692

Arthur D. Little, Inc.

Cambridge, Massachusetts

C-81181

January 1981

Arthur D. Little, Inc.

This book was prepared as an accounit of wark sponsored by an agency of the United States Government. Neither the United States Government nor any agency thereot, nor any of their employees, makes any warranty, express or implied, or assumes any legal lizbility or responsibility for the accuracy. 


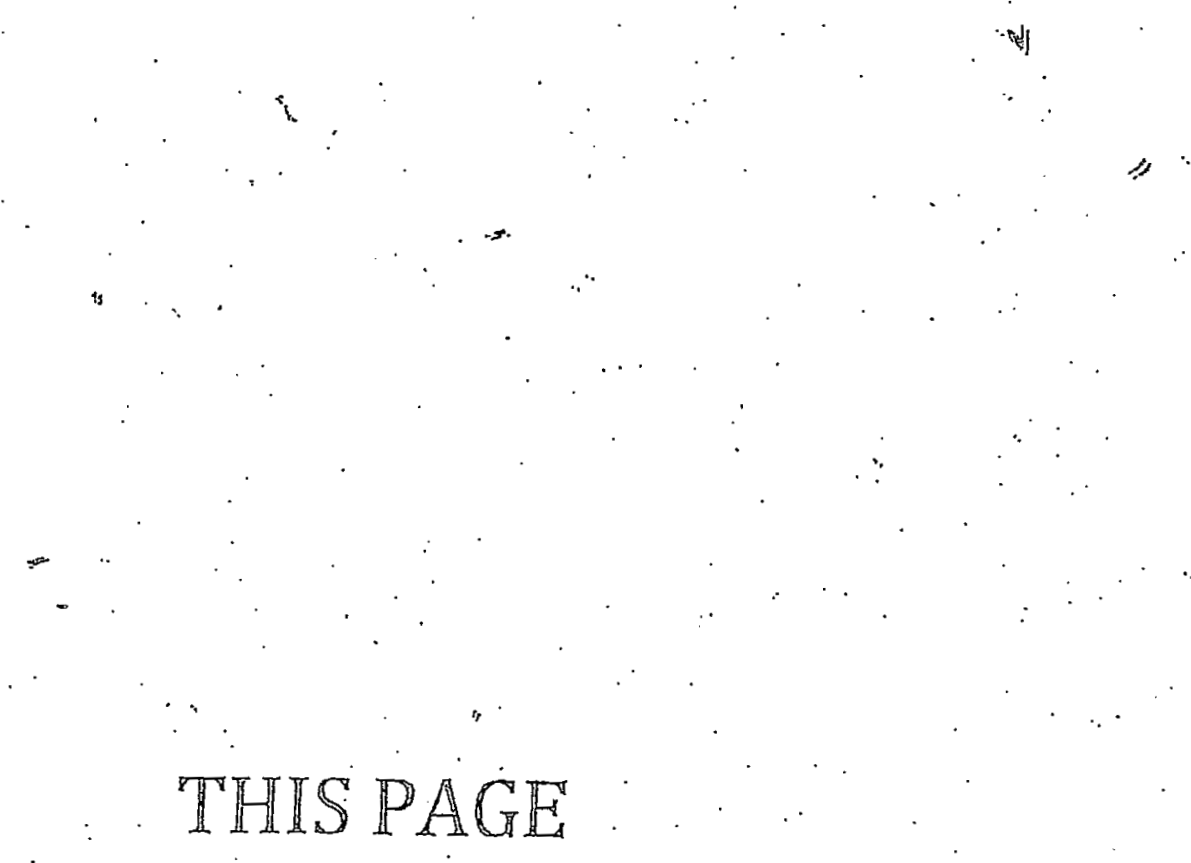

WAS INTENTTONALLY

LEFT BLANK 
List of Figures vii

I. SUMMARY 1

A. OBJECTIVES 1

B. SCOPE 1

C. APPROACH AND FINDINGS 1

II. IRON AND STEEL INDUSTRY 5

A. INDUSTRY CHARACTERIZATION 5

B. COKEMAKING 11

C. IRON AND STEELMAKING 27

D. STEELCASTING, REHEATING AND HEAT TREATING 62

E. OTHER ENERGY CONSERVATION OPPORTUNITIES : 75

III. ALUMINUM INDUSTRY 87

A. INDUSTRY CHARACTERIZATION 87

B. ALUMINA MANUFACTURE AND ALUMINUM 105 REDUCTION

C. ALUMINUM MELTING 120

IV. OTHER HIGH-TEMPERATURE INDUSTRIES

A. COPPER 123

B. MAGNESIUM 138

C. PORTLAND CEMENT

D. GLASS INDUSTRY 151

$\begin{array}{ll}\text { APPENDIX } & 159\end{array}$ 


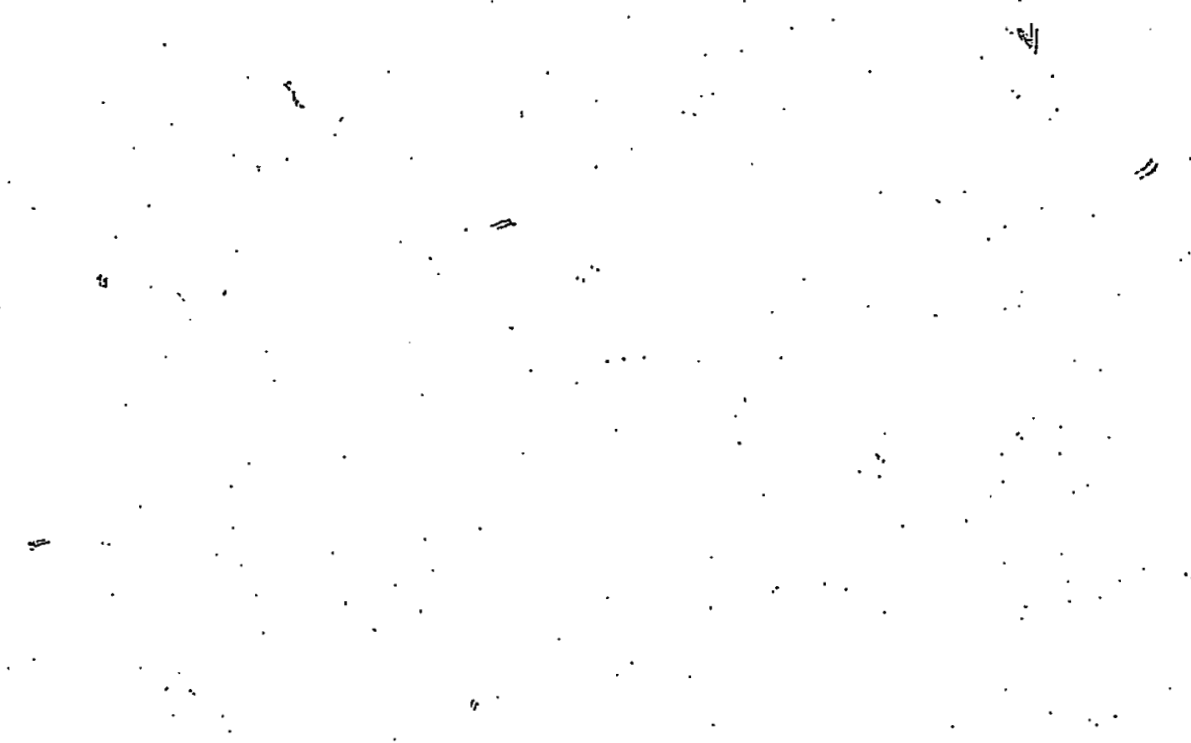

THIS PAGE

WAS INTENTIONALLY

LEFT BLANK 


\section{LIST OF TABLES}

Table No.

Page

I-1 Overview of Energy Savings and Development Costs of

Selected Technologies

II-1 National Energy Consumption in the Steel Industry

by Fuel Type

II-2 Materials Used by Blast Furnaces in the Manufacture

of Iron (Pig and Molten) in 1979

II-3 Energy Consumption in the Blast Furnace 32

II-4 Principal Direct Reduction Processes 41

II-5 Energy Requirements of the Conventional and 43

Direct Reduction Steelmaking Routes

II.6 Hot Metal Desulfurization Processes 45

11.7 Energy Consumption for Two Scrap Preheating Options 56

II-8 Potential Energy Savings Associated with BOF Scrap 57.

Preheating

II-9 Estimated Capacities of U.S. Steel Industry Soaking 63

Pits and Reheating Furnaces

II-10 Energy Saving From Hot Inspection and Conditioning 65

Followed by Direct Rolling

II-11 Energy Saving From Carburizing All Heat-Treatable 70

Alloy Steels

II-12 Origin and Quantity of Recoverable Materials From 76

Flue Dusts and Mill Scale in the U.S. Iron and Steel Industry (1978)

II-13 Processes for Recycling Flue Dusts and In-Plant Fines 78

II.14 Results From Project on Hierarchical Computer Control 84

Systems - Purdue Laboratory for Applied Industries Control

$\begin{array}{lll}\text { III-1 U.S. Alumina Plants/Capacities } & 89\end{array}$

III-2 U.S. Primary Aluminum Plants/Capacities 91

III-3 Bayer Alumina Production - Range of Requirements 102

and Considered Average Requirements

III-4 Hall-Heroult Aluminum Smelting Range of Requirements 104

and Considered Average Requirements

III-5 Energy Use in Scrap Preparation 106

III.6 Aluminum: Reverb Furnace Melting Aluminum Scrap 106 to Alloy $\mathbf{3 8 0}$ Ingots

III-7 Aluminum: Reverb Furnace Melting Aluminum Scrap 107 to Hot Metal (Alloy 380)

III.8 Aluminum: Recycling Aluminum Cans to Hot Metal 108 for Can Sheet Stock 


\section{LIST OF TABLES (Continued)}

Table No.

Page

III-9 Selected Patents - Direct Reduction of Aluminum

116 to Product Aluminum-Silicon Alloys

III-10 Energy Saving from Using Coal in All Primary

122

Aluminum Melting Furnaces

IV-1 . Energy Use in Mining for a Stripping Ratio of $\mathbf{1 . 2 5}$

125

IV-2 Energy Use in Copper Pyrometallurgy Technology

126

for Smelting and Refining

IV-3 Energy Use in Copper Hydrometallurgical Technology

IV.4 Characterization of Research Ideas

136

IV-5 Production of Magnesium Metal From Seawater

140

IV-6 Energy Consumption Profile of Conventional

147

Technologies 


\section{LIST OF FIGURES}

Figure No.

Page

II-1 Geographical Distribution of the Iron and Steel 7

Industry

II-2 Process Unit Interrelationships 9

II-3 Estimated U.S. Level-1 Energy Consumption by 12

Major Process Units in 1979

II.4 Energy Consumption for U.S. Steel Products in 1979

II.5 FMC Formcoke Process 17

II.6 CONSOL-BNR Formed Coke Process 19

11.7 BFL Formed Coke Process 20

I1.8 Dry Coke Quenching Systems 25

II.9 Amanda Coal Injection - Low-Pressure Air Systems 33

Plus Coal Pulverizing/Collecting

11.10 Amanda Pressurized Coal Injection System 34

II-11 Schematic of BOF Off-Gas Recovery System 50

II-12 Schematic Diagram of an OBM-S Furnace 54

II-13 Schematic Diagram of an Internally Fired Fluidized 72

Bed Furnace

II-14 Schematic Diagram of an Externally Fired Fluidized 73

Bed Furnace

II-15 Network of Computing Functions 81

II-16 The OITA Hierarchical Computer System 83

III-1 Location of Alumina Plants and Aluminum Smelters 88 in the United States

III-2 Bayer Process for Producing Alumina 93

III-3 An Electrolytic Furnace with Baked Block Anode 97

III-4 Electrolytic Furnace with Side-Stub Soderberg Anode ， 98

III-5 Electrolytic Furnace with Vertical Stubs 99

III.6 Voltage Losses in Hall-Heroult Cell 110

III.7 Alcoa Chloride Process (Assumed Scheme) 113

IV-1 Energy Flowsheet Production of Magnesium Metal 139

From Seawater

IV-2 Conventional Process for Manufacturing Glass 153

IV-3 Schematic of Pelletizing and Batch Preheating System 154 


\section{SUMMARY}

\section{A. OBJECTIVES}

The Federal Government, through the Department of Energy (DOE), has initiated a program to develop innovative energy-saving technologies. In the specific area of high-temperature processes, DOE's Office of Industrial Programs has focussed on developing energy-saving technologies relating to such industries as iron and steel, aluminum, copper, magnesium, and stone, clay, and glass. If successful, these technologies would significantly reduce the dependence of these industries on all forms of energy, particularly on natural gas and liquid fuels.

At present, the DOE has numerous energy conservation projects involving hightemperature processes in various stages of development. The status of these programs range from a fact-finding stage to those ready for commercialization. The purpose of this assignment was to analyze these projects to:

- Quantify their energy conservation potential;

- Determine their present status of development;

- Identify their research and development (R\&D) needs and estimate the associated costs; and

- Determine the most effective role for the Federal Government in developing these technologies.

In this study, in addition to analyzing specific energy conservation projects in detail, we developed a preliminary list of other potential energy conservation projects in these industries which may be of further interest (see Appendix A).

\section{B. SCOPE}

The scope of this program was limited to analyzing 25 energy conservation projects, selected by DOE, in the following high-temperature industries:

- Iron and steel,

- Aluminum,

- Copper,

- Magnesium,

- Cement, and

- Glassmaking.

\section{APPROACH AND FINDINGS}

Our basic approach to meet the objectives described above was to collect and analyze technical literature describing the energy conservation projects under consideration. Information sources included the DOE, our own in-house data bases, pub. lished articles, and information gained in interviews with selected industry experts. In analyzing this information, we determined both the energy conservation potential of these projects and $R \& D$ needs and then estimated costs incurred in undertaking these projects. 
The methodology for accomplishing this analysis was generally project-specific and, as such, we have included a project description within separate sections. In each of these sections, we have discussed the following topics:

- General description of the energy-conserving project;

- Energy conservation potential (based on 100\% market penetration);

- Present status of development;

- Research and development needs; and

- Role of the Federal Government in aiding or expediting project development.

An overview of these findings is summarized in Table I-1 highlighting:

- National energy conservation potential;

- Developmental costs; and

- Elapsed time for commercial development. 
TABLE 1-1

OVERVIEW OF ENERSYY SAVINGS AND DEVELOPMENT COSTS OF SELECTED TECHNOLOGIES Technology Proposed
to DOE

Form coke

Dry quenching

Improvements in blast

furnace technology

Hot blast cupola

Direct reduction

(coal based;

External desulfurization

$\omega$

BOF off-gas utilization

Scrap preheat

Computer model of

electric furnace

Particle melting

Hot inspection

Improved slot forge

Nitrogen-based

carburizing

Fluid-bed heat treating

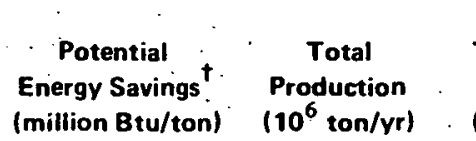

Potential

Total Energy

Saved ${ }^{\top}$

Conventional

Technology

By-product

coke oven

Wet quenching

Blast furnace

Cupola with no

air preheat

Blast furnace

Product

Coke

Desulfurization

in blast furnace

BOF

BOF

steel-making

Electric

furnace

Electric

furnace

Reheat furnaces

Slot forge

Conventional

carburizing

Conventional

heat treating iron

Coke

Pig Iron

\section{2}

$0.08-1.2$

$0.1-1$

(3)

Pig iron

Pig iron .

$0.8-0.9$

87.

53.5

$0-6^{1}$

64

87.

7-110

11.

1-10

87.

(3)

Raw steel

$0.66-1.04$

83.

56-86

$0.6-3.85$

Raw steel

Raw steel

0.25

Raw steel

0.34

Raw steel

2.3

Steel forging

3.-5.

Carburized

steel

Finished

steel

$128 . \quad 294$

2 to $3 \quad \cdots \quad 6-15$

5.6

10

40.

$10-30$

$\begin{array}{cc}\begin{array}{c}\text { Estimated } \\ \text { Development } \\ \text { Time } \\ \text { (yr) }\end{array} & \begin{array}{c}\text { Devel/Demo } \\ \text { Cost }\end{array} \\ \left(10^{6} \$\right) & \text { Present Status }\end{array}$

3-7

$100-500$

Limited BF tests promising. No

large coke plants in existence.

10-20 Demonstrated outside U.S.

5-100 Modifications proposed to demonstrate technology.

0.2-0.5 Under test

10-100 Reliable coal bosed energy efficient process is needed.

0.2-0.5 Commercially developed.

$1-10$

Economic system needs to be demonstrated.

KMS concept demonstrated abroad; under development in U.S.

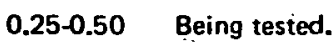

$2-5$
0.5-1 Laboratory scale test.

Initial design phase.

Being commercialized

Being commercialized

0.2-0.5 Under development. 
TABLE I-1 (Continued)

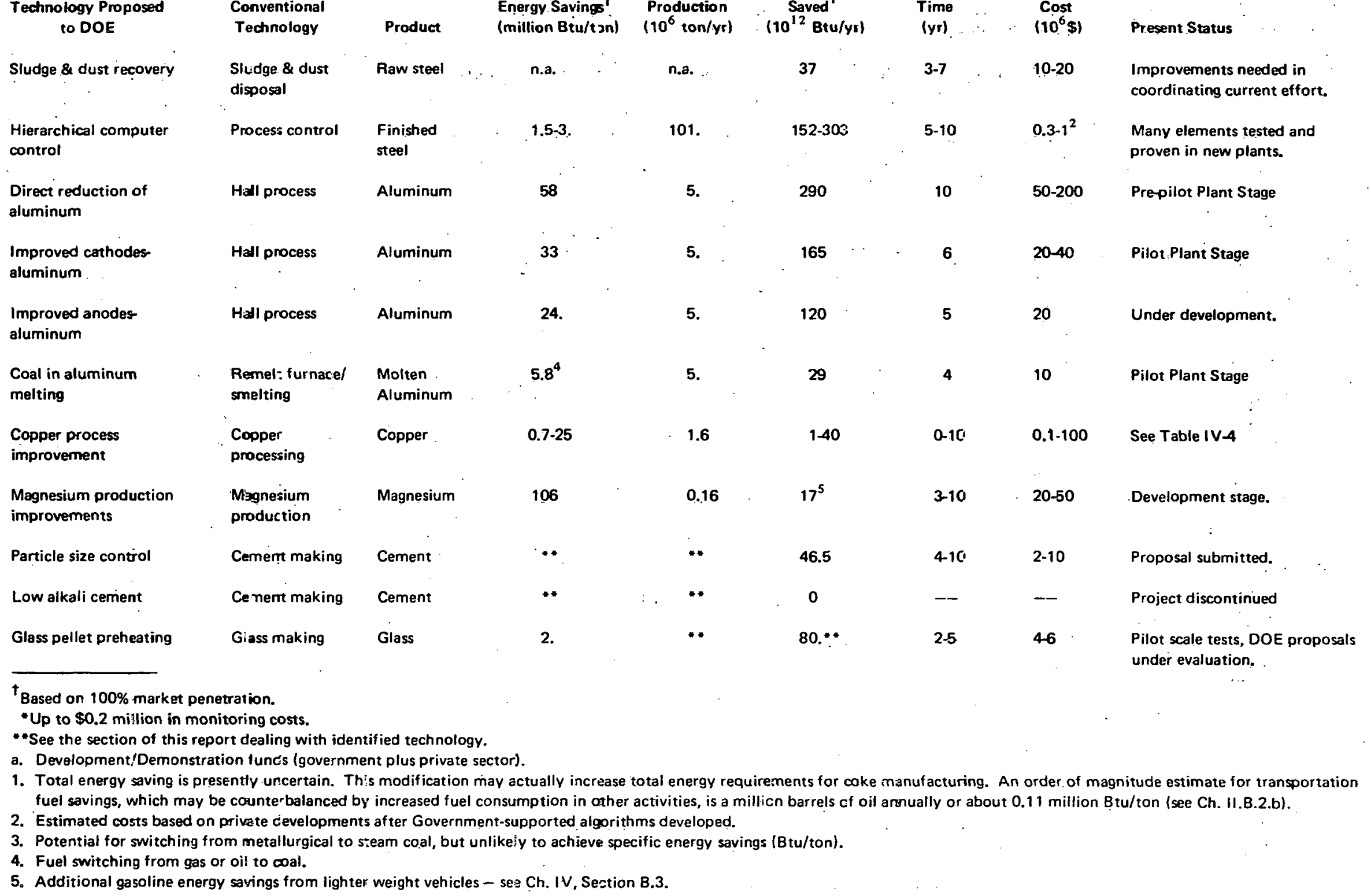




\section{IRON AND STEEL INDUSTRY}

\section{A. INDUSTRY CHARACTERIZATION}

\section{Description of the Industry}

\section{a. Energy Efficiency}

Present-day U.S. steel facilities were built, for the most part, at a time when fuels were plentiful and available at low cost; energy was used as economically as could be justified, given relative capital costs, productivity, and the like. Now, the iron and steel industry must give consideration to energy-efficient production technologies. This is easier to do in newer facilities. The industry has made a significant effort to modernize its aged plants, but there are major hindrances, including difficulties in retrofitting existing facilities, concern relating to capital availability, the high cost of borrowed capital, and necessary expenditures for pollution abatement.

The overall energy efficiency of the steel industry, defined as the ratio of its useful output energy to its total input energy (Battelle, 1975), is only $42 \%$. However, this is relativey good when compared to a $3.5 \%$ efficiency for the copper industry, a $29.6 \%$ efficiency for the aluminum industry, and a $23.9 \%$ efficiency for the glass industry.

\section{b. Plant Categories}

Plants producing raw steel may be categorized into two broad groups: fully integrated and non-integrated. A third category consisting of steel-finishing operations is often identified as well.

Fully integrated plants are engaged in both iron- and steelmaking operations. The integrated plants start with iron ore and coking coal, from which pig iron (or hot metal) is produced in blast furnaces. The resulting hot metal, along with scrap, is charged into steelmaking furnaces to produce molten raw steel, which is subsequently cast and fabricated into finished steel products. More recently, a small number of plants have incorporated technology for the direct reduction of iron ore (thereby bypassing blast furnace operations), which is then made into steel in electric arc fürnaces.

Non-integrated plants (or cold metal shops) use scrap steel, pig iron, or, in some cases, purchased sponge iron made by direct reduction furnaces as raw materials. Charges of these materials are melted and refined in electric arc furnaces. A special group of small cold metal plants are classified as mini-mills; many of these mills have annual capacities of less than 200,000 short tons and limit their production to bar mill products, rebars, and merchant bars.

The third category of plants in the steel industry is involved in steelfinishing nperatinns. These plants purchase semi-finished steel, such as slabs, blooms, or billets, produced by integrated or non-integrated manufacturers, which they use for finish 
rolling and/or additional fabrication to final products. Many such plants are satellite finishing operations for the raw-steel producers.

Steel producers can also be classified by the type of steel produced: carbon, alloy or stainless steel. Carbon steel is the predominant grade of steel shipped, accounting for more than $85 \%$ of the total tonnage of steel produced in the United States.

\section{c. Plant Locations}

The geographical distribution of the major iron and steel facilities is shown in Figure II-1. The six states bordering the Great Lakes; viz., New York, Pennsylvania, Ohio, Indiana, Illinois and Michigan, historically have accounted for more than $75 \%$ of the total U.S. steel output. Within these states are found about $80 \%$ of the integrated plants and approximately $70 \%$ of the non-integrated and finishing steel plants. This industry concentration has resulted primarily from the accessibility of raw material sources, transportation arteries, and major steel-consuming markets.

About $80 \%$ of the industry's requirements for metallurgical-grade coal, an important raw material in pig iron production, is produced in West Virginia, Pennsylvaniu, Kentucky, and Alabama. The heart of the iron ore industry in the United States is the Great Lakes iron mining district in Minnesota and Michigan. Small but significant production also occurs in New York, Pennsylvania, Alabama, Missouri, Texas, Wyoming; Utah, Georgia, Wisconsin, and California.

\section{Description of Established Processes}

The flow of material and the functions of the unit operations in the ironmaking, steelmaking, and steelforming sequences of a typical integrated plant are depicted in Figure 11-2.

Iron ore mined in open pits or, in a few cases, in underground operations may be shipped directly to the ironmalcer or processed at the mine site to produce a high iron concentrate in a number of ways, including both dry and wet magnetic separation, electrostatic separation, and flotation and gravity separation. Since the resulting concentrates are quite fine in particle size, it is usually necessary to agglomerate these materials into larger sizes by pelletizing or sintering to prevent entrainment of iron values in blast furnace offgases.

Other raw materials used in ironmaking operations include limestone and coal. Coal must be converted to coke in large, externally heated coke ovens. In this process, volatile materials contained in the coal are driven off and a solid product (coke) that can withstand the high temperatures and tremendous crushing pressures fonnd in a blast furnace is created:

The blast furnace process continues to be the major techniques for ironmaking. In this process, coke, limestone, and iron-bearing raw materials are fed in at the top of the blast furnace shaft. Preheated air is then forced into the bottom of the shaft, through tuyeres, to react with coke and thereby generate heat (at temperatures higher than $3000^{\circ} \mathrm{F}$ ) and carbon monoxide. Iron oxide is reduced to elemental iron effectively by reaction with the hot carbon and carbon monoxide. Limestone, calcined by the heat 


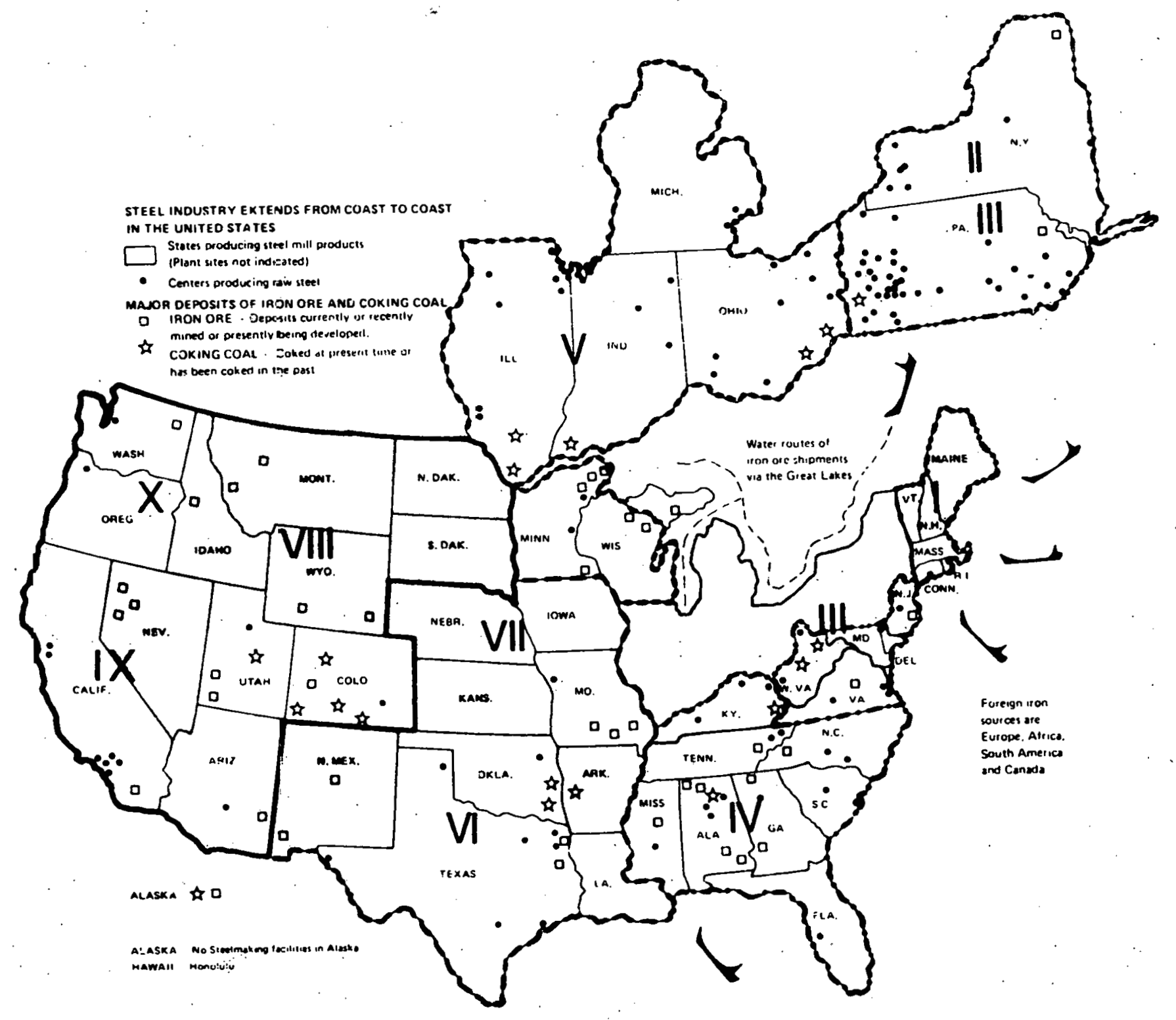

Source: Arthur D. Little, Inc., 1975.

FIGURE II-1 GEDGRAPHICAL DISTRIBUTION OF THE IRON AND STEEL INDUSTRY 
to producej lime, combines with gangue materials in the ore and coke to produce a liquid siag. The molten iron, saturated with carbon (at about $4 \%$ carbon by weight), is tapped from the furnace bottom, along with slag. Part of the blast furnace offgases, after cleaning, are burned in regenerative air heaters to provide the hot air blast, and recovered flue dust is sent to the sinter plant for recycling.

The hot liquid metal is transferred in ladles or refractory-lined cars to one of a number of steelmaking processes, where carbon, silicon and other impurities are oxidized from the metal phase.

The basic oxygen furnace (BOF) has become the predominant method for making raw steel since its introduction in the early 1950's. In this type of furnace, blast furnace hot metal is the major source of iron, usually comprising 70-80\% of the total metallic charge, with the remainder being scrap. In $1979,61 \%$ of the total U.S. raw steel production was effected by the BOF method.

The open hearth furnace, for many years the workhorse of the domestio stecl industry, has yielded to the dominance of the BOF process in the last 15 years. Although. $14 \%$ of the total U.S. raw steel was produced by open-hearth furnaces in 1979 , the process is generally considered to be obsolete due to unfavorable economic and environmental factors surrounding its operation. As the open hearth continues to be phased out, both the BOF and electric furnace will play ever-increasing roles in domestic steelmaking.

The electric furnace process for steelmaking commonly uses scrap as the major source of iron units. Sponge iron, produced by the direct reduction of iron ore, has also been found to be practical for up to $50 \%$ of the charge. Electric arc furnaces may be used to produce the full range of carbon steels, medium-alloy structural steels, specialty steels, stainless steels, tool steels, and super-alloys.

After refining, molten steel is commonly tapped into ladles and then poured into ingot molds. Solidified ingots are stripped from their molds and placed in fuel-heated soaking pits. The soaking pit ensures a uniform ingot temperature for subsequent rolling to produce slabs, billets, or blooms. Alternatively, the energy-conserving, continuous-casting process is used to produce billets, blooms, or slabs directly, thus bypassing the soaking pits.

Slabs, blooms, and billets are normally stored before further processing to finished steel products. This final processing includes such operations as rolling, galvanizing, shearing, cleaning, and annealing. Final products may become structural shapes, rails, bars, wire, pipe, sheet, or strips. Flat products are often galvanized, tinplated, aluminum-coated or painted as an integral part of the steelmaker's operation.

\section{Energy-Use Profile}

Energy requirements for the manufacture of various steel products can be calculated on a variety of bases. Two of the most common are: 


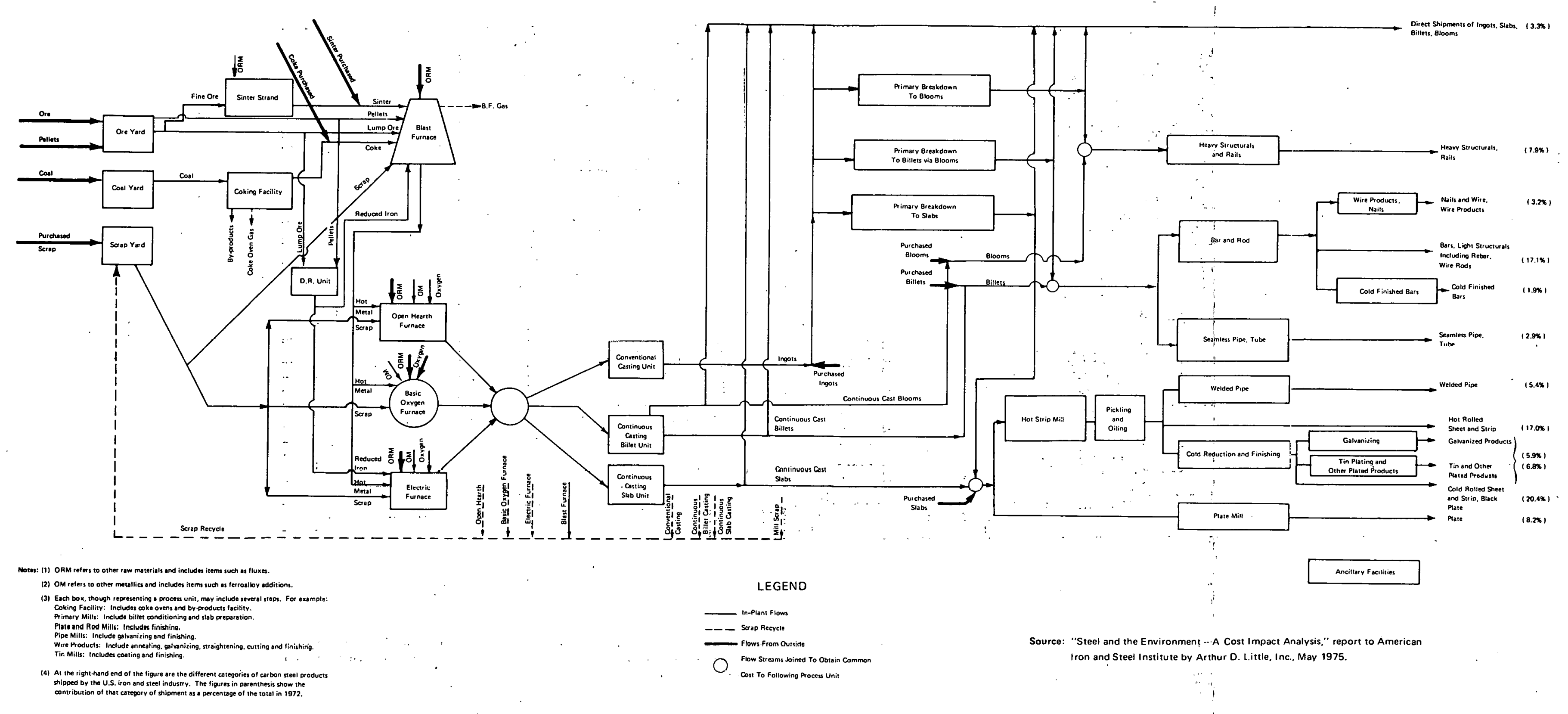

FIGURE II-2. $\quad$ PROCESS UNIT INTERRELATIONSHIPS 


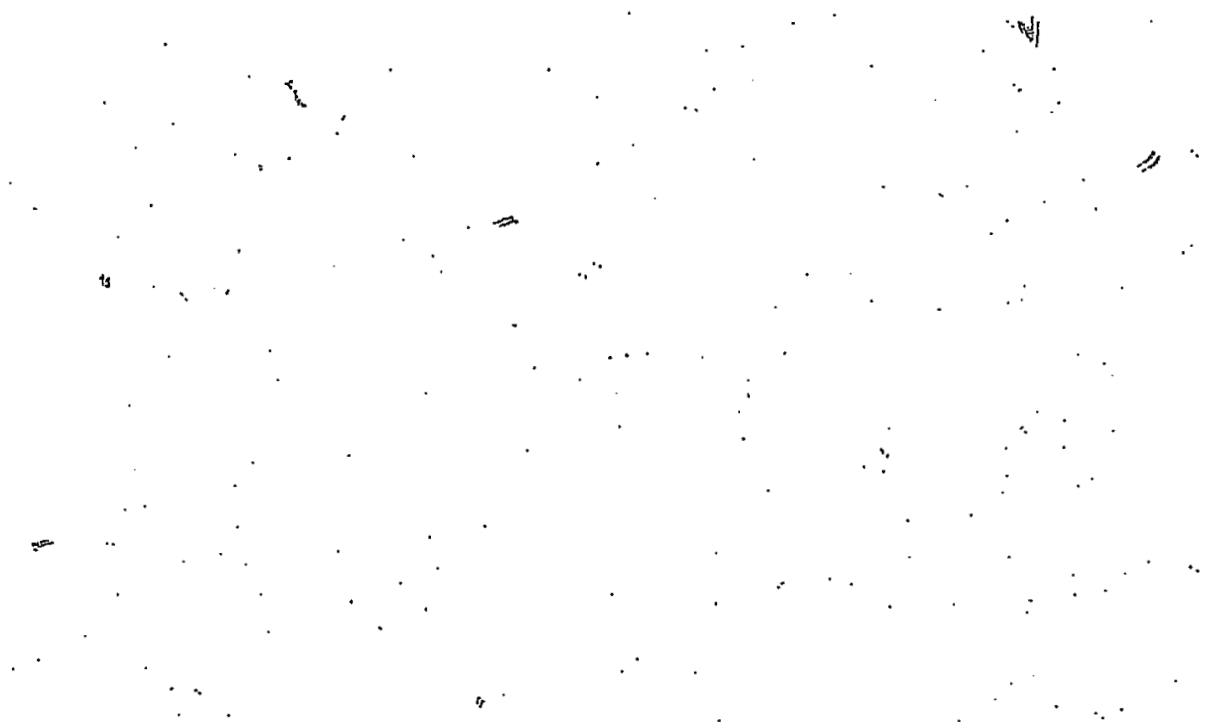

THIS PAGE

WAS INTENTIONALLY

LEFT BLANK 
- Direct use of fuels, electricity, steam, and the like; and

- Direct energy use, as above, plus energy requirements for the manufacture of materials consumed in steelmaking, such as lime or refractories.

In energy accounting terminology, the first method is known as a Level 1 analysis; while the second is labeled a Level 2 analysis. In this study, Level 2 analyses were generally used, except as noted. Quantities of energy used for the iron and steel industry, as a whole, can be examined from three different viewpoints: (1) by major process unit; (2) by finished product; or (3) by type of fuel consumed.

\section{a. Major Process Unit}

Figure II-3 presents an estimate of the 1979 energy consumption in the U.S. iron and steel industry broken down by process unit. Blast furnaces are, by far, the largest energy consumers, accounting for about $45 \%$ of the total energy used in the industry. Heating/annealing furnaces, coke ovens, steelmaking furnaces, and casting/ breakdown operations use roughly $10 \%$ each. The remaining $15 \%$ is used in all other process units.

\section{b. Finished Product}

Processes involved in producing finished steel products require varying and different process steps to achieve desired properties for the end-use. Figure II-4 shows the distribution of energy consumption for major U.S. steel product lines in 1979, as reported by the American Iron and Steel Institute.

\section{c. Type of Fuel Consumed}

Energy consumption in 1979 by fuel type for the domestic steel industry (calculated from AISI statistics) is shown in Table II-1. Fuels directly derived from coal supply about $65 \%$ of the total energy used. Natural gas and petroleum-based fuels supply $30 \%$, and purchased electricity contributes the remaining $5 \%$.

\section{B. COKEMAKING}

\section{Conventional Technology}

Approximately 1.46 tons of metallurgical coal are consumed in the production of each ton of metallurgical coke. This coal is a specially selected blend, having particular characteristics of sulfur content, volatile content, and caking properties. It is usually delivered to steel plants in rail cars. A portion of the coal delivered to the site is put into storage, and the remainder is transferred to a conveyorized coal preparation system, typically by a tracking stacker/reclaimer. Coal reclaimed from or bypassing the piles passes through a bar grizzly station equipped with a tramp metal magnet used to remove any large or ferrous foreign material. The coal is then screened, and the oversized material is crushed to particles less than $1 / 2$ inch in size. The crushed coal is typically metered from storage bins by weigh belt feeders to obtain the desired coking coal blend in the feed to the coke ovens. Oil may be mixed with these blended coals to control bulk density. The resulting coking coal blend is stored in stocking bins above the coke ovens. 


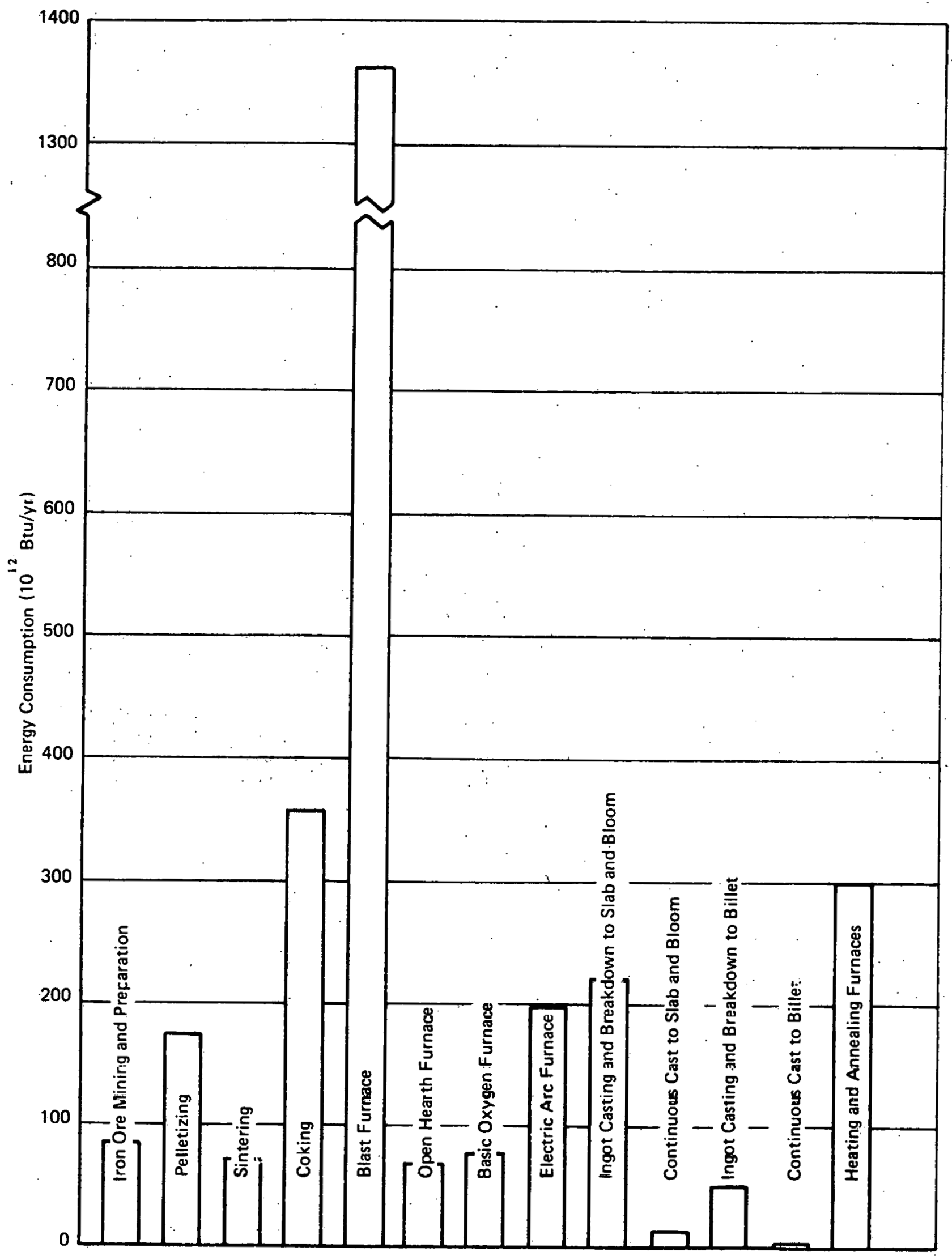

FIGURE II-3 ESTIMATED U.S. LEVEL-1 ENERGY CONSUMPTION BY MAJOR PROCESS UNITS IN 1979 


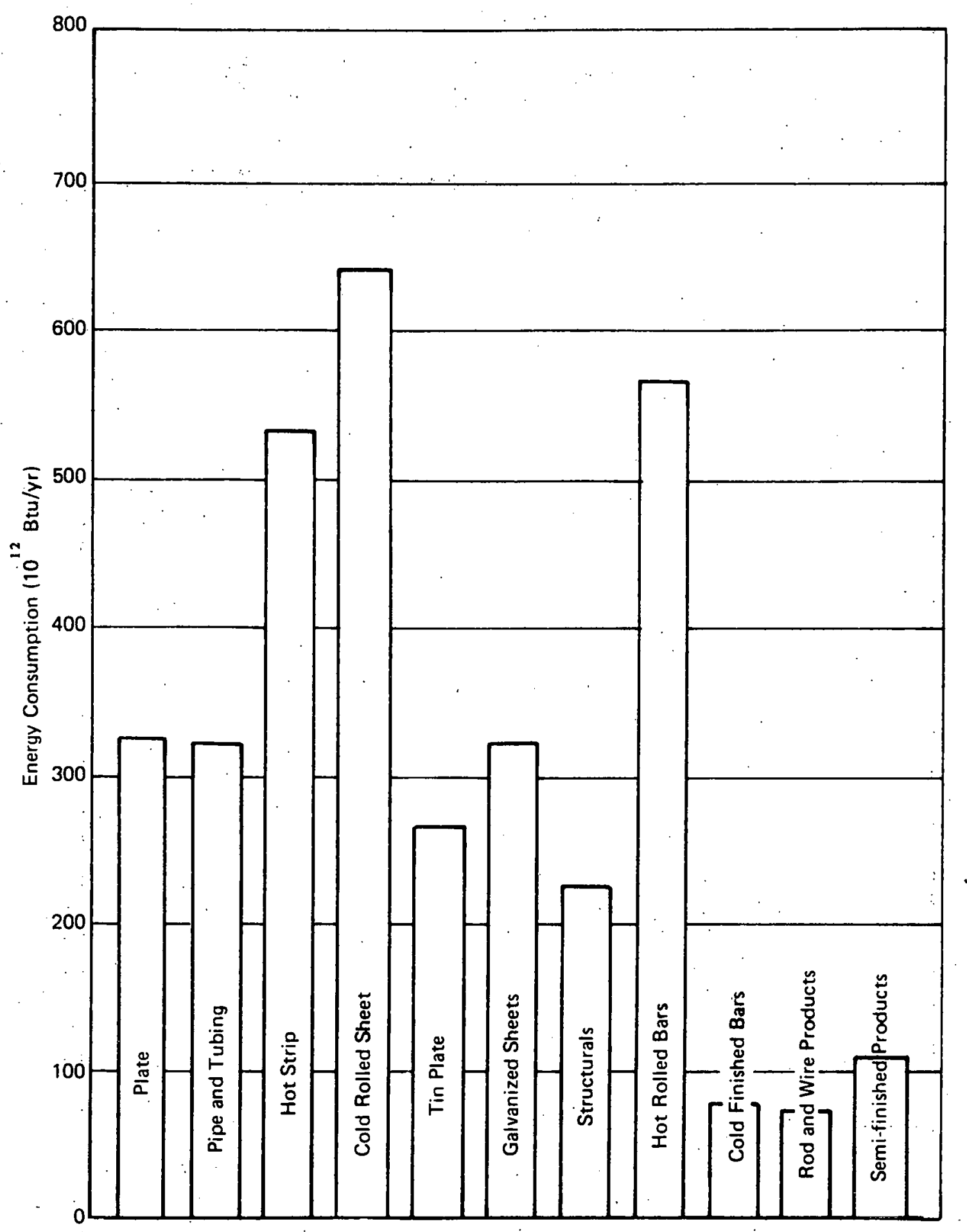

FIGURE II-4 ENERGY CONSUMPTION FOR U.S. STEEL. PRODUCTS IN 1979 


\section{NATIONAL ENERGY CONSUMPTION IN THE STEEL INDUSTRY} BY FUEL TYPE

\begin{tabular}{lc} 
Fuel Type & Consumption \\
\cline { 2 - 2 } & $\left(10^{12}\right.$ Btu/yr $)$ \\
Coal & $1,824.9$ \\
Tar and Pitch & 5.4 \\
Coke & 177.9 \\
Coke Oven Gas & 3.6 \\
Natural Gas & 659.2 \\
Middle Distillate Fuels & 13.5 \\
Residual Fuel Oil & 206.5 \\
Liquid Petroleum Gas & 1.1 \\
Other Petroleum Fuels & 2.8 \\
Purchased Electricity & 165.1 \\
Other Fuels & 5.0 \\
Total Energy Consumption & 3.065 .1 \\
& \\
"Based on 3413 Btu/kWh & \\
Source: AlSI Report to U.S. Department of Energy on Energy Efficient \\
$\quad$ Improvement and Recovered Material Utilization, 1979.
\end{tabular}

\section{Gross Energy Consumption}

59.5

0.2

5.8

0.1

21.5

0.4

6.8

$-$

0.1

5.4

0.2

100.0

The coke oven battery is a refractory structure consisting of many slot ovens, each typically 50 feet long, 20 feet high, but only $16-1 / 2$ inches wide. The gas spaces between the slot ovens form combustion and flue gas chambers in which the coke oven gas, or enriched blast furnace gas, burns to heat (underfire) the ovens. Hot combustion products pass into brick checkerwork regenerators beneath the ovens on a cyclic basis; alternately, combustion air is blown through the hot regenerators to preheat it prior to combustion. The coking coal blend is charged through three or four charging ports in the roof of each slot oven commonly by a special coal-charging vehiole, oallod a larry car, which runs on rails along the roof of the battery.

During coking, the coal is baked in the oven for 16 to 20 hours, reaching temperatures as high as $2012^{\circ} \mathrm{F}$. Since air is excluded from the slot ovens, the coal does not burn, but is transtormed to hard, porous coke. Volatile gases and liquids are driven off from the coal during coking and are evacuated from the oven by steam aspirators. The gases are collected in mains that run the length of the battery and are conveyed to the byproduct plant, where valuable tars and oils are recovered and noxious gases (such as $\mathrm{H}_{2} \mathrm{~S}$ ) are removed. Some of the gas is returned from the byproduct plant to the coke oven battery for underfiring; the remainder is used as fuel in other parts of the steel plant. 
On one side of the battery are special pushing machines which move on rails the length of the battery. These machines serve two purposes:

- They push levelling bars through the ovens, just beneath the roof, to level the charge of coal in each oven, and

- They push the coke out of the ovens.

When the coal in an oven is fully coked, the pusher machine lines up with the door, opens the door, and uses a ram to expel the coke through an open door on the other; or coke, side of the oven. On the opposite side of the battery are coke-side door machines, which open the doors on that side and, to reduce air pollution, may tow portable coke guides which enclose the coke as it exits from the oven.

When the coke is discharged from the oven through the coke guide, it is collected in a hot coke transfer car. This car conveys the hot coke to a quenching station or tower, where it is cooled by overhead water sprays. Once quenched, the coke is discharged onto a coke wharf, where further cooling takes place and where hot spots can be detected and extinguished. The cool coke is then screened into blast furnace coke (particles greater than $3 / 4$ inch) and smaller buckwheat coke and coke breeze.

The raw coke oven gas withdrawn through the slot oven ascension pipes is rich in valuable tars and oils, but contains noxious gases, such as $\mathrm{NH}_{3}, \mathrm{H}_{2} \mathrm{~S}$, and $\mathrm{HCN}$. - Traditionally, this gas is quenched to $100^{\circ}-200^{\circ} \mathrm{C}$ by flushing liquor (primarily water) sprays in the coke oven gas mains. The gas is further cooled by indirect heat exchange in the primary coolers located in the byproduct plant. Tars and naphthalene are recovered by condensation. Much of the ammonia is recovered by absorption in the flushing liquor; the remainder may be recovered by various absorption processes. Light oil (consisting primarily of benzene, toluene, and xylene) is typically recovered by absorption in a petroleum oil. A number of processes are available to desulfurize of the coke gas. The light oil is generally sold to petroleum refiners or chemical companies; the tar and naphthalene recovered may be either sold or burned on site as boiler or blast furnace fuels.

In addition to the common byproduct oven, there are two variations of coking technology which are employed: preheated byproduct ovens, and beehive ovens.

Over the last decade, a number of domestic coke plants have been built or retrofitted with coal preheating systems. A typical coal preheating operation involves further crushing of the coal to particles less than $1 / 8$ inch. Coke oven gas, blast furnace gas, or natural gas is burned to supply a high-velocity, inert gas stream that will entrain, heat, and dry the coal as it is conveyed in a series of risers and cyclones. The preheated coal, at approximately $392-482^{\circ} \mathrm{F}$ and $1 \%$ moisture, is collected from the gas stream by cyclones and electrostatic precipitators and is conveyed to hot coal charging bins. From these bins it travels to the ovens by a stream-fluidized pipeline, enclosed chain conveyor, or modified larry car.

Coal preheaters are more thermally efficient than slot ovens in raising coal to a temperature level of $200-250^{\circ} \mathrm{C}$. The use of preheated coal also reduces the residence 
time required in the slot ovens. Fuel use may thus be reduced, typically by $10 \%$, compared to non-preheated batteries.

Beehive ovens represent a much simpler means of producing coke than byproduct ovens. In beehive, or other non-recovery-type ovens, the hydrocarbons and other gases released during coal pyrolysis are not recovered and refined. Instead, the pyrolysis products are used directly to fire the ovens or other equipment. Beehive ovens account for a very small $(<1 \%)$ fraction of the coke produced, and have limited applicability because of environmental concerns.

In 1977 , approximately 53.5 million tons of coke were produced in the United States, almost all by the conventional byproduct oven technology described above. More than $90 \%$ of this coke was consumed by blast furnaces, at the rate of approximately 0.61 ton of coke for each ton of steel produced. Production of this coke consumed 84.7 million tons of metallurgical coal.

The production of each ton of metallurgical coke yields 13,000-19,000 SCF uf cuke oven gas containing $450-550 \mathrm{Btu} / \mathrm{SCF}$. About $40 \%$ of this gas is returned to underfire

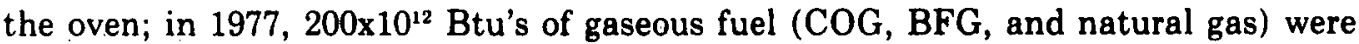
consumed in underfiring coke ovens. Total energy consumption in coke ovens-including steam and electricity consumed by the ovens themselves, by the coal preparation systems, and by the byproduct plants-represented approximately $276 \times 10^{12}$ Btu's in 1977, excluding the fuel value of the metallurgical coal.

\section{Formed Coke}

\section{a. Description}

Formed coke processes represent the most direct approach to reducing the steel industry's consumption of metallurgical coal. Although numerous variations of the process have been developed around the world, all have in common, to varying degrees, the substitution of cheaper, non-coking coals for conventional metallurgical coal. This substitution is accomplished by more sophisticated chemical processing of the coals and mechanical forming of the coke product. In general, formed coke processes may be either continuous or batch continuous, but all are totally enclosed. As such, they hold the potential for more effective pollution control than can be achieved with conventional coke oven batteries.

Two formed coke processes have been developed in the United States to demonstration scale: the FMC Formcoke process and the Formcoke Associates' coke pellet process. The FMC process (Figure II-5) is the most advanced formed coke process in the world. Coal of any type is flash-dried, if necessary, and ground to particles of less than $2.5 \mathrm{~mm}$. It is then heated by partial combustion to successively higher temperatures in three fluidized beds operating at 320,905 , and $1562^{\circ} \mathrm{F}$, respectively. Volatile matcrials are collected by a tar condenser, and a low-Btu (100.200 Btu's per SCF) fuel gas is produced. The calcinate is cooled to about $212^{\circ} \mathrm{F}$ in another fluidized system before being blended with air-blown pitch produced from the tar. The process is selfsufficient in pitch if the feed coal contains more than $35 \%$ volatiles. The mix is 


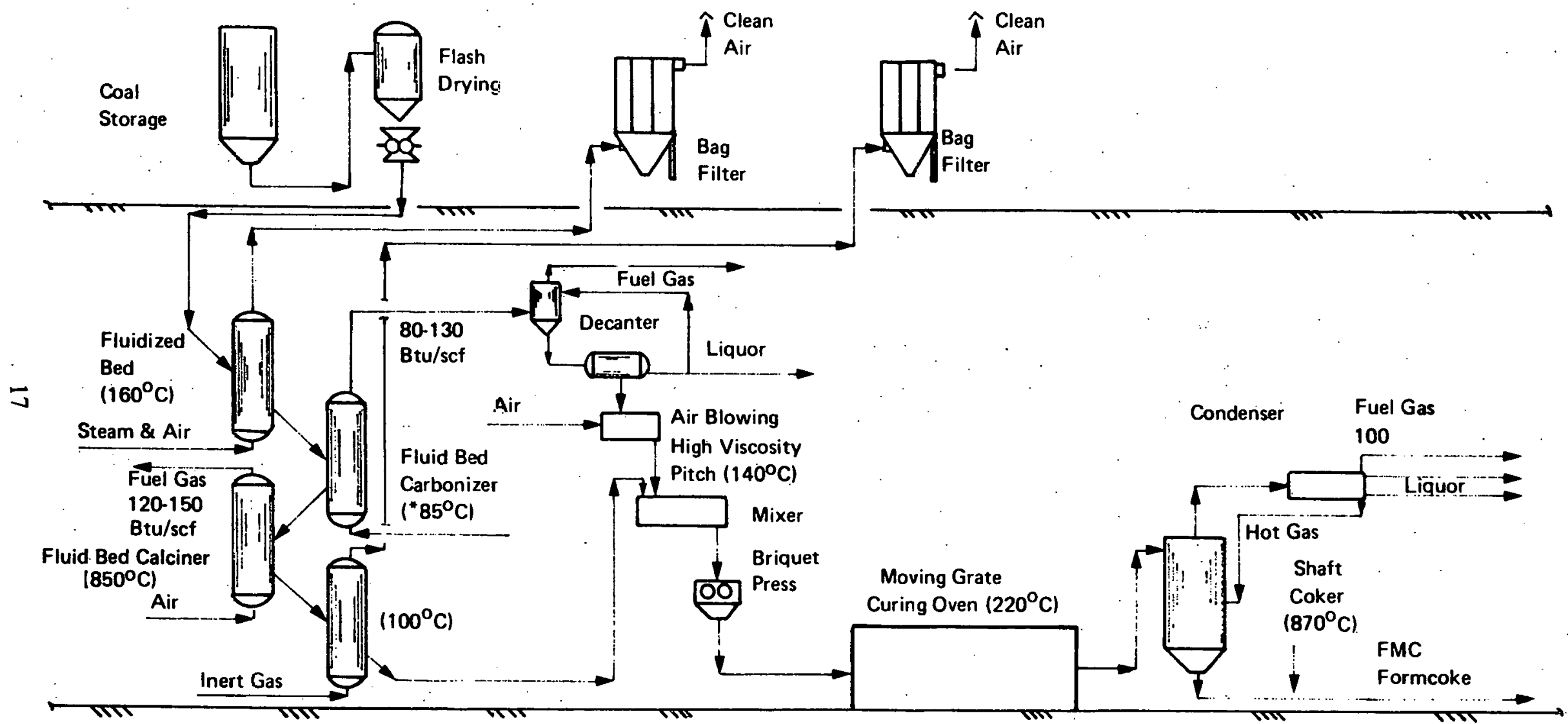

Source: Arthur D. Little, Inc.

FIGURE II-5 FMC FORMCOKE PROCESS 
briquetted in a double-roll press, and the briquettes are cured in oxygen-free air in a moving-grate oven. The cured briquettes are finally coked at elevated temperature in $a$. shaft coker, similar to the Lurgi Spülgas oven.

The Formcoke Associates' coke pellet process was developed by a consortium composed of the Consolidation Coal Company, Bethlehem Steel, National Steel, and Republic Steel. In this process, preheated, crushed coking coal is mixed with recycled coke fines, finely divided char made in a fluidized bed, and perhaps pitch. This blend of products is hot-pelletized in a rotary kiln at $842^{\circ} \mathrm{F}$. The pellets are then coked in a continuous shaft furnace of the Lurgi Spülgas design. The process is outlined schematically in Figure II-6.

Perhaps the must advanced fureign process is the BFL process (Figure II-7) developed by Bergbau Forschung GmbH (BBF) and Lurgi Mineralotechnik GmbH (West Germany). A char-making coal of any rank is ground to pellets of less than 10 $\mathrm{mm}$, flash-dried to less than $2 \%$ moisture, and then fed to a carbonizer of the Lurgi Ruhrgas (LR) type. In the carbonizer, the dry coal is mixed with 5-10 parts of hot $\left(1382^{\circ} \mathrm{F}\right)$ recycled char, passed through a devolatilization chamber, and is finally calcined in a vertical-shaft flash calciner, reaching a maximum temperature of about $1372^{\circ} \mathrm{F}$. (Alternatively, carbonization may occur in a fluidized bed; Lurgi claims higher product density with the LR carbonizer.) Off-gas from the LR carbonizer has a heating value of $500-600 \mathrm{Btu} / \mathrm{SCF}$; some tar and oil are recovered with this gas. A binding coal with more pronounced caking qualities is also ground and dried, and then mixed with the char (and some tar) for briquetting in a double-roll press. Normally, the briquettes are then heat-cured at $1022^{\circ}-1112^{\circ} \mathrm{F}$ for 1 to 3 hours to reduce volatiles to $5 \%$ and to improve strength and abrasion resistance. Briquettes are finally cooled in a water bath and stored with $2-3 \%$ moisture content. Lurgi claims these "green" briquettes can be used directly in a blast fumace. Alternatively, to produce fully coked briquettes, Lurgi suggests the use of a BBF sand-shaft carbonizer.

Other formed coke processes are under development in other countries: the DKS formed coke process in Japan, the HBNPC process in France, the Ancit process in West Germany, and the Sapozhnikov process in the U.S.S.R.

\section{b. Potential for Energy Savings}

Formed coke processes were not developed with the intent of saving thermal energy or oil or gas, but rather of substituting more abundant non-coking coals for the conventional metallurgical coals. Those developed to date do this with varying degrees of success. The FMC process can reportedly use almost any coal without requiring the addition of coking coal to a blend. The BFL and Formcoke Associates' coke pellet processes do require some coking coal, ranging from $5 \%$ to $25 \%$ of the total blend, depending on the other coals used. Generally, formed coke processes require slightly more coal per ton of coke than do conventional byproduct ovens, but the exact ratio of coal to coke varies considerably, depending on process configuration and on coal quality. 


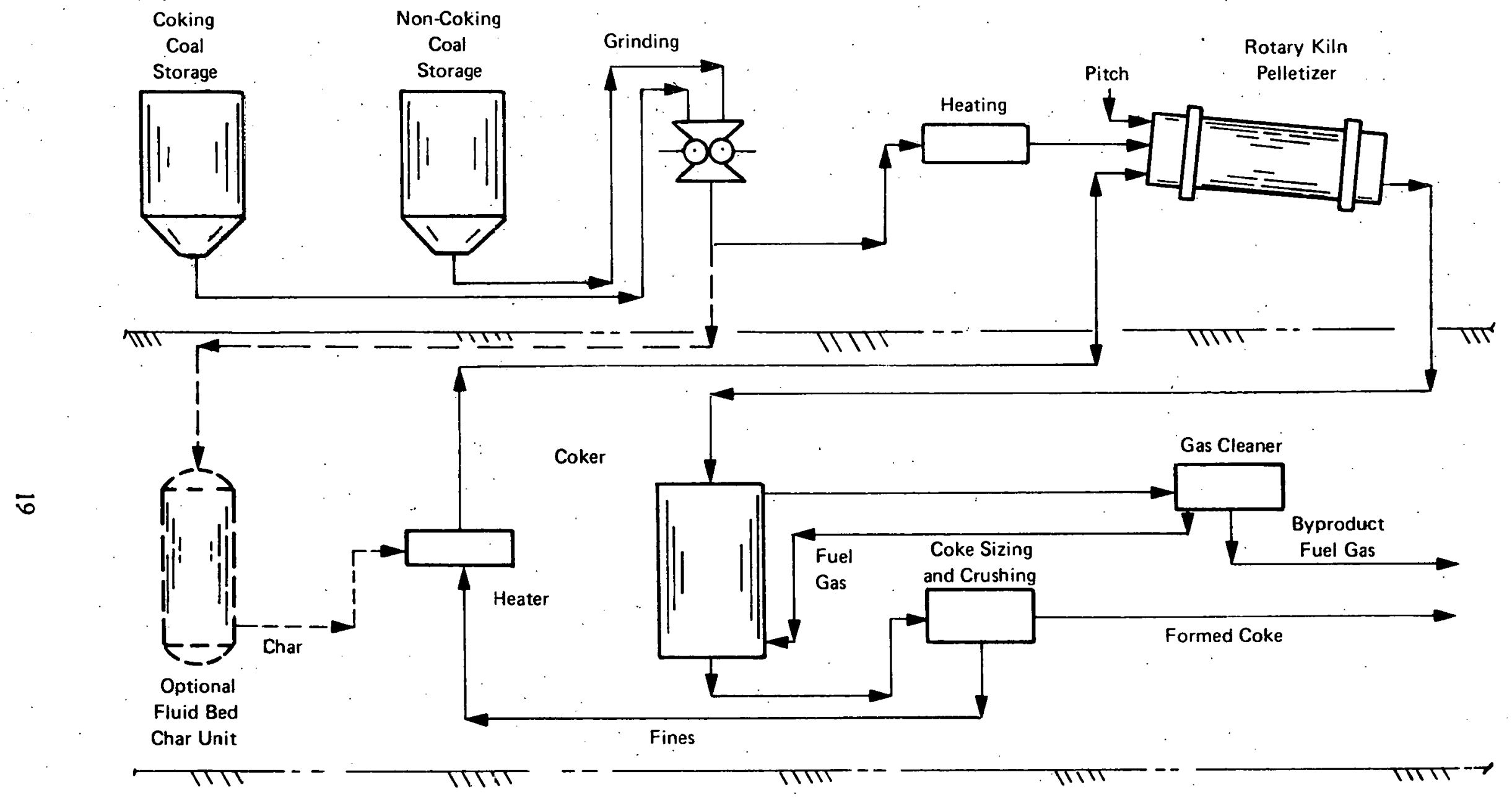

Source: Arthur D. Little, Inc.

FIGURE II-6 CONSOL-BNR FORMED COKE PROCESS 


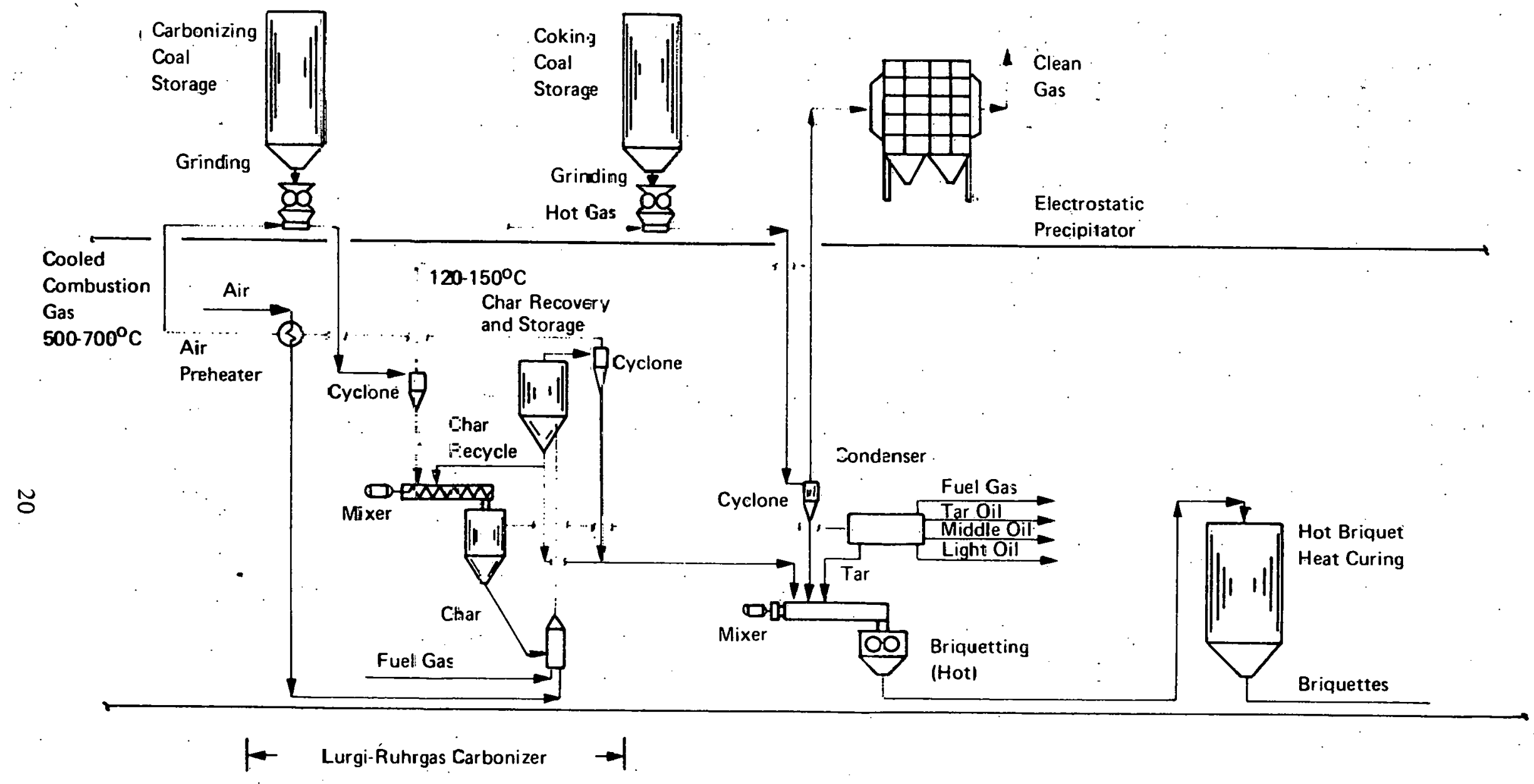

Source: P. Sehmalfeld and R. Remmlexr, "New Results of the Development and Fresent Stage of the BFL Hot Briquetting Process," presented at 13th Biennial Conference of the Institute for Briquetting and Agglomeration, August 1973.

\section{F:GURE II-7 BFL FORM ED COKE PROCESS}


The impact of formed coke technology on the domestic consumption of oil and natural gas is less clear. The limited data available suggest that the net fuel byproducts available from formed coke processes will be comparable to that of byproduct ovens. Since formed coke processes can permit the use of more readily available coals, energy consumption for coal transportation may be reduced. If, for example, the average haul were reduced by 140 miles through the use of different coals, then fuel used in rail transport of coal for coke might be diminished by 1 million barrels of oil per year. However, in terms of Btu's, this swing might be overwhelmed by differences in the net gas make of formed coke and conventional coke technologies. The net gas make of a given technology is strongly influenced by the quality of the coal feed and by the objectives of the plant designers in terms of whether coke yields or gas production are maximized. Thus, accurate estimates of net energy savings with formed coke can only be made on a site-specific basis.

The key question regarding the byproduct energy available from formed coke processes is not so much the quantity available, but rather the heating value of the byproduct gas. It would be very difficult and expensive to retrofit existing steel plants designed to use 500-Btu coke oven gas to a new fuel gas with a much lower Btu content. The off-gas available from the FMC process generally contains an average 150 Btu's per SCF. (Some unpublished pilot plant work suggests that 300-400 Btu's per SCF may be achieved.) The off-gas from the BFL process is of higher heating value, as already mentioned. The average heat content of the net gas from the Formcoke Associates' coke pellet process is believed to be in the 300-400 Btu's per SCF range.

\section{c. Present State of Development}

FMC began to develop its process in 1956. The first blast furnace test of its Formcoke occurred in 1962, and others were conducted by Armco in 1967, by Inland Steel in 1970.71 and 1973, and by British Steel Corporation in 1970-71. The later tests were very successful. Formed coke from FMC's Kemmerer, Wyoming, plant is reportedly available to the steel industry for blast furnace testing at a cost of approximately $\$ 120$ per ton.

We understand that Inland Steel Corporation recently prepared a proposal for the demonstration of blast furnace coke production using the FMC process. Preliminary engineering of this project was undertaken in the preparation of the proposal. Currently, agencies of the Federal Government are considering what roles they might play in such a demonstration.

Davy-McKee, licensor of the FMC process, is simultaneously attempting to sell commercial plants to other steel companies and other interested parties both in the United States and abroad. As yet, no commitments have been made for the construction of a new formed coke plant.

The Formcoke Associates' coke pellet process represents an improvement over Consolidation Coal's disco process, which was originally developed in the early 1930's. In 1964, 40 tons of coke pellet were produced for testing by the U.S. Bureau of Mines in 
the experimental blast furnace at Bruceton, Pennsylvania. A large demonstration plant was built in the early 1970's at Bethlehem Steel's Sparrows Point facility, but it was shut down in July 1977 without ever achieving design production rates or extended operating runs. The plant has been mothballed by its sponsors for lack of funds. A proposal for resuming the development of this technology has been prepared by Formcoke Associates.

Bergbau Forschung began studies on a continuous formed coke process in 1962. A 5-ton-per hour pilot plant began operation at Essen in 1965. Since then, BF and Lurgi have jointly developed the process and produced more than 25,000 tons of both green and coked briquettes. Blast furnace tests have been conducted fairly successfully by AIRBO, ${ }^{*}$ Hoesch, Rheinstahl and the British Steel Corporation (BSC). Two large plants were built for BSC and Ruhrcoal, but the latter was shut down in 1973 and has not been successfully restarted. At last report, the BSC-operated facility was still not in operation.

\section{d. $R \& \dot{D}$ Needs and Development Costs}

The economics of formed coke are uncertain, since few successful plants have been built. However, we estimate that formed-coke processes will cost as much as conventional byproduct ovens with associated pollution control technology. The cost of the first unit of a modified FMC Formcoke demonstration plant of a 1000-tpd capacity has been estimated to be $\$ 100$ million or more. The construction of such a "plant is the logical next step in developing the technology; it would demonstrate the operational reliability of the process and allow long-term blast furnace tests under controlled production conditions to confirm the suitability of the product for this use. When long-term blast furnaces are included, total development and demonstration costs may approach $\$ 500$ million (total private sector plus any Government funding):

The environmental impact of a formed-coke process and the quality of byproducte could also be dotermined from this domonstration plant; byproduct quality and operational reliability will directly affect the overall economics of the demonstration plant. Any formed coke produced by a new or updated process would need extensive blast furnace tests before being accepted by the steel industry.

The developers of formed-coke processes have long claimed that their product can be produced more cheaply than conventional metallurgical coke. If this is proved by a large-scale demonstration project, then steel producers should have a strong economic incentive to consider formed-coke plants.

\section{c. Role of the Federal Government}

The DOE has sponsored a number of evaluations of the formed coke proposals it has recently received. All of these studies reached conclusions that were generally favorable to the developers of the technology. Although there was some disagreement on specific approaches to the demonstrations, all found that formed coke might truly

\footnotetext{
•Association Internatlonale pour Les Recherches au Bas Fourneau d'Ougrëe
} 
improve blast furnace efficiency, reduce coking emissions relative to conventional byproduct ovens, permit the use' of a wider range of coals in coke production, and be demonstrated at a cost comparable to that proposed. None of the studies specifically addressed the potential impact of formed-coke production on the domestic use of premium fuels (i.e., oil and gas), although it is difficult to do so, given the lack of largescale operating data.

The limited data now available indicate that commercialization of formed-coke technology would have a small impact on the U.S. consumption of oil and gas, compared to several of the other technologies reviewed in this report. Thus, an appropriate federal role should be carefully evaluated. Although the formed-coke process would permit the use of a wider range of coals, some studies have suggested that the domestic supply of conventional metallurgical coals appears to be adequate.

Other federal agencies may be more appropriate sponsors of formed coke. The Environmental Protection Agency has a clear interest in the promise of reduced coking emissions. Conventional coke plants are major sources of criteria pollutants $\left(\mathrm{SO}_{\mathbf{x}}\right.$ and particulates), and are of real concern as hazardous air pollutants come under scrutiny (e.g., benzene, polynuclear aromatics). Thus, the EPA might be an appropriate source of demonstration funding; it might also provide other, non-monetary forms of encouragement. For example, one of the concerns steel companies have about formed-coke technology is the reliability of the plants as they might be operated; another is the uncertainty that a new design would actually reach its design capacity. The EPA might find it useful to permit extended operation of dirtier, but more reliable, conventional batteries to protect the operating company from such uncertainties as a prolonged outage of the formed coke plant for repair, for example.

The Department of Commerce has an interest in the viability of the domestic steel industry, and in the impact of material shortages on foreign trade. For the last decade, steelmakers have been forced to spend enormous sums on pollution control and have been strongly pressured by foreign competition. The ability of the industry to finance much needed capital improvements, not to mention R\&D of new technology, has been impaired. Refurbishment and replacement of coke batteries has been particularly hard hit, and coke may once again be in short supply if the industry returns to a high level of activity. A significant amount of coke has been imported in response to past or anticipated shortages, with a negative impact on the U.S. balance of trade.

Certain states would also benefit from the commercialization of formed coke, through increased use of local coals. They might be an appropriate source of financial incentives for a formed-coke demonstration project.

\section{Dry-Coke Quenching}

\section{a. Description}

In conventional cokemaking, the sensible heat of the incandescent coke leaving the oven is wasted as the coke is quenched by water sprays in a wet-quench tower. The objective of dry-coke quenching is to recover this considerable amount of sensible heat by transferring it to a hot inert gas, which could then, in turn, be used to heat steam, 
compressed air, or some other working medium for power recovery, steam generation, coal preheating, or other applications.

Two dry-coke quenching systems are now available:

- The Soviet system, now being promoted in this country by the Patent Management Company; and

- The Sulzer process, now exclusively licensed in North America by the Pennsylvania Engineering Company from American Waagner-Biro Company, Inc.

The two systems are quite similar, as illustrated in Figure II-8; the most significant difference is the addition of a "pre-chamber" (holding bin) in the Suviet system which allows an equalization of coke temperature and stabilization flow rate in the cokecooling chamber. The resulting equalization in heat extraction is accomplished differently in the Sulzer process by incorporation of a recirculating gas bypass, which allows a portion of the cooled gas from the heat exchanger to bypass the coke cooling chamber and $\mathrm{mix}$ with the hot gas returning to the heat exchanger.

Referring to Figure II-8, one can see that dry cooling is accomplished by collecting the hot coke from the ovens in hot coke hoppers. These hoppers are conveyed by rail to the dry-coke quenching facility and lifted to the top of the hot coke bunker, where they are discharged. Pollutant emissions at this transfer point are minimized by careful control of the local pressure during hot coke loading. The coke drops into the cooling bunker at $1832^{\circ}-2012^{\circ} \mathrm{F}$. As cool $\left(392^{\circ} \mathrm{F}\right)$ inert gas flows upward through the hot coke, it picks up heat and leaves the cooling bunker at $1200^{\circ}-1470^{\circ} \mathrm{F}$. An impacttype, coarse-particle separator removes large coke particles from the hot inert gas in the Sulzer system; a dropout chamber performs a similar function in the Soviet system. From the coarse-particle separator, the hot gas passes through a heat exchanger system, where its heat is usually transferred to water, generating highpressure steam. When it leaves the heat exchange section, the inert gas has cooled to $300^{\circ}-390^{\circ} \mathrm{F}$. Fine coke particles are removed in a cyclone before the gas is returned by a blower to the cooling bunker.

\section{b. Energy Conservation Potential}

Estimates of the thermal energy recoverable in dry-coke quenching systems vary from 1.1 to 1.3 million Btu per ton of coke, depending on the coke temperature and the design temperature of the gas leaving the heat exchanger section. If we use a reasonable average of 1.2 million Btu per ton and assume that dry coke quenching is applied to all coking facilities in the United States, we find that $64 \times 10^{12}$ Btu per year would potentially be recovered. This thermal energy recovery will require some additional consumption of electric power, but the latter would be small in comparison with the thermal energy retrieved. 

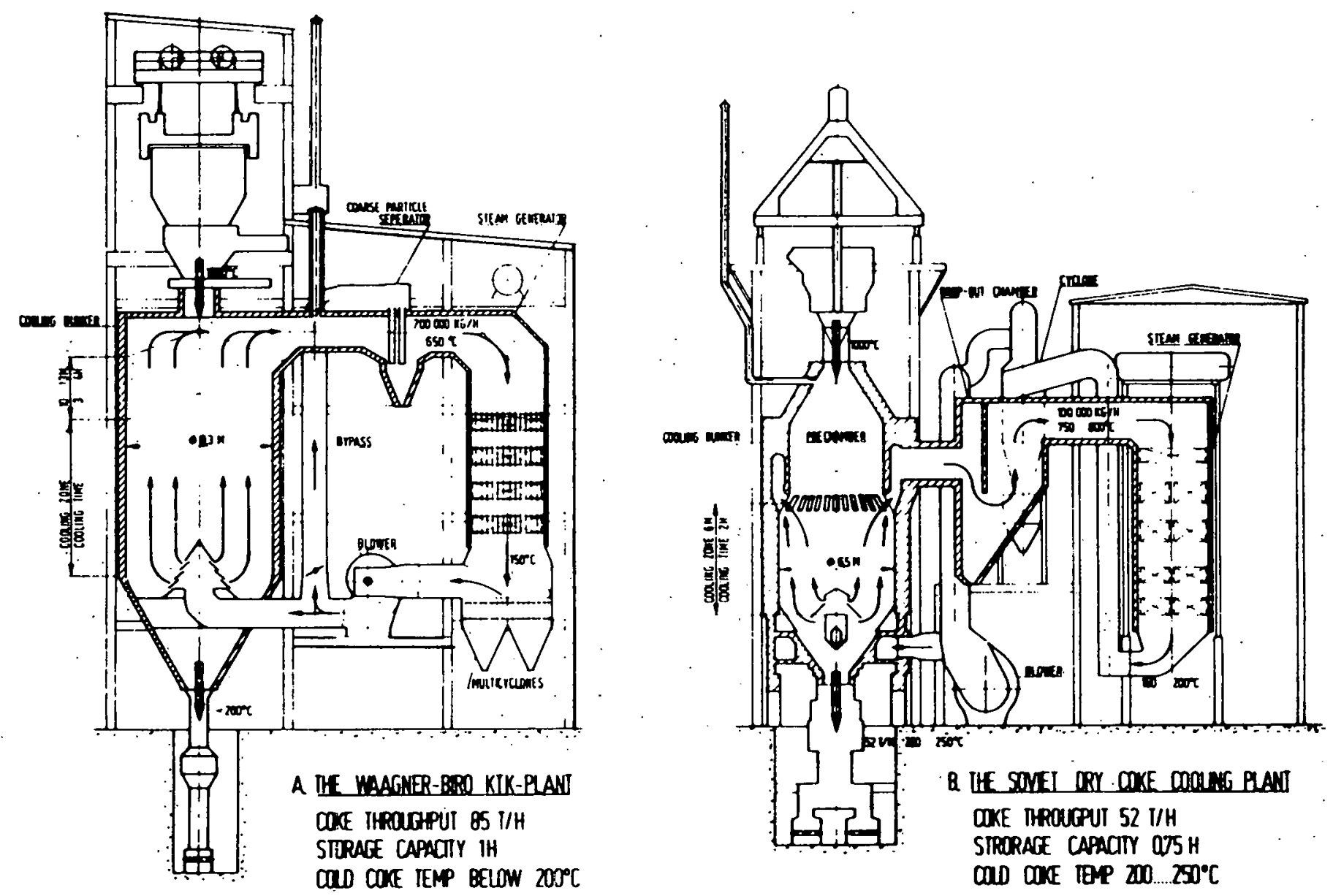

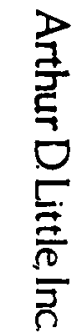

Source: R. Kemmetmueller, "Economics of Dry Coke Cooling," American Waagner-Biro Co., Inc., 1976.

FIGURE II-8 DRY COKE QUENCHING SYSTEMS 


\section{c. Present Status of Development}

Hundreds of dry-coke quenching facilities were installed earlier in this century, but almost all were abandoned when cheap supplies of energy made their operation uneconomical. One of these early facilities has been operated at Ford Motor Company's Dagenheim, England, plant since the 1930's, and a similar operation is still in use in Homecourt, France. The Soviet Union has been actively developing dry-coke quenching systems since the 1960's and now has more than 50 installations in operation; such facilities are now mandatory in the U.S.S.R. for all new coke oven batteries, as well as for rebuilt batteries, if space permits. Variations of the Soviet designs have been licensed and constructed by the Japanese, but no dry-coke quenching systems have yet been built in North America.

Un the basis of the above experience, the energy recovery potential of dry-coke quenching can be accepted as proven. 'I'he major questions that remain concern the influence of dry-coke quenching on coke yield and blast furnace operations, potential environmental benefits, and reliability.

The capital cost of a new 2 million ton per year dry-coke quenching facility is approximately $\$ 20$ million. This is much more than the cost of a conventional wet quenching facility of equal capacity. However, if constructed as a part of a new cokemaking operation including coal preparation, coke ovens, and coke handling equipment, the cost would represent less than $10 \%$ of the total capital investment. In a recent economic analysis, by American Waagner-Biro Company, Inc., projected a 3- to 5-year payback rate for the capital investment in a dry-coke quenching facility. This analysis was based on firm cost estimates made for 10 prospective customers, and on a steam energy value of $\$ 3.75$ per million Btu.

In contrast, a study by AISI* showed a pretax payback period of about 18 years. The major differences between the two studies were that:

(1) AISI's estimated investment per annual ton was $\$ 20.54$, while WaagnerBiro estimated $\$ 10.00$, and

(2) the AISI study valued steam at about half the cost used by WaagnerBiro.

Recently, the DOE funded a study of a method of dry-coke quenching by the U.S. Steel (USS) Corporation. The most significant difference between the USS concept and the designs already described was the relocation and reconfiguration of the battery/quench coke transfer system. In the USS concept, coke falls into a cooler adjacent to the battery, and is isolated from the atmosphere during the transfer by a movable coke guide. This eliminates the potential for emissions present in the hot coke transfer system of the Soviet and Sulzer designs. The USS effort is just beginning, and will involve construction and testing of a pilot plant.

\footnotetext{
- "Energy Conservation in the Steel Industry," 84th General Meeting of American Iron and Steel Institute, May 1976.
} 


\section{d. $R \& D$ Needs and Development Costs}

In recent years, the U.S. steel industry has been short of capital and has maintained that dry-coke quenching facilities could not be justified on the basis of the potential return on investment. In addition, it has shown no confidence in the limited information available concerning the operational reliability and benefits of the process. This attitude will probably obtain until dry-coke quenching is demonstrated in this country.

The potential environmental benefits seem almost certain. However, the EPA has had difficulty mandating this technology in new installations, because it has not been adequately demonstrated; the major operational experience has been in the U.S.S.R., and the information available from that country has not been adequate to convince U.S. producers.

The energy conservation potential of dry-coke quenching is a certainty. Both theoretical analyses and actual operating experience have indicated recovery potentials in the same range. Actual capability to use the recovery energy will depend on individual steel mill layouts. The first step in demonstrating this conservation potential would be a new engineering study of a dry-coke quenching facility adapted to a particular site. The next step would be the construction of an actual facility to quench 1.2 million tons per year. The required capital investment for such a facility would fall in the range of $\$ 10-20$ million. Once this plant was constructed and operational, blast furnace testing of the resulting coke and environmental monitoring of the process operations would determine the validity of other claimed benefits.

This demonstration phase of dry-coke quenching technology could be accomplished within five years. Since a large number of domestic coke ovens will have to be replaced in the coming decade, the potential exists for significant penetration of the industry by this new technology within 10 to 15 years.

\section{e. Role of the Federal Government}

Both the DOE and the EPA have reason to be interested in dry-coke quenching; the technology can both save energy that might conserve oil or gas, and can also reduce particulate emissions. Certainly funding of a dry-coke quenching process may enhance adoption of this technology. If the prices of fuels were higher than they are now, then the steel industry would find it easier to justify dry-coke quenching on economic grounds. However, the industry is concerned with the reliability of dry coke quenching systems.

\section{IRON AND STEELMAKING}

\section{Conventional Technology}

Conventional technology in iron and steelmaking consists of the production of hot metal (pig iron) in a blast furnace, after which it is refined into raw steel in an open-hearth, electric arc or basic oxygen furnace. Because the open-hearth process is considered to be an obsolescent technology, a description of the process will not be described. 


\section{a. Blast Furnace}

In 1979, domestic blast furnaces produced about 87 million net tons of pig iron and consumed about 134 million net tons of iron-containing raw materials (ore, pellets and sinter), 17.2 million net tons of flux and about 50 million net tons of metallurgical coke. AISI statistics on blast furnace charge materials per ton of pig iron produced are presented in Table II-2.

TABLE $\| \mathbf{H}-2$

\section{MATERIALS USED BY BLAST FURNACES IN THE MANUFACTURE OF IRON (PIG AND MOLTEN) IN 1979}

\begin{tabular}{lc} 
Material & $\begin{array}{c}\text { Net Ton Used } \\
\text { per Ton of } \\
\text { Iron Produced }\end{array}$ \\
Ore: & \\
Iron ore (including manganiferous and block) & 0.110 \\
Manganese ore (including ferruginous manganese) & 0.004 \\
Agglomerated products (sinter, pellets, etc.) & 1.455 \\
Total ores and agglomerated products & 1.569 \\
Less flue dust and sludge produced & 0.029 \\
Net - ores and agglomerated products & 1.540 \\
Scrap: & \\
Total scrap & \\
Less produced at blast furnaces and auxiliary units & 0.052 \\
Net - Scrap & 0.017 \\
\hline Mill cinder, roll scale, etc. & 0.035 \\
Limestone, dolomite, other flux materials & 0.054 \\
Coke: & \\
Total coke & \\
Less coke breeze recovered & 0.198 \\
Net coke & \\
\hline
\end{tabular}

Suurce: Arnlual Stalistical Repurl, AlSI, 1979.

The blast furnace is basically a vertical-shaft unit that burns solid carbon fuel in the presence of iron-bearing raw materials and flux (charged to the top of the shafts) and reduces the iron oxides to elemental iron as the charge descends. Hot air, injected under pressure through tuyeres in the base of the furnace, causes partial fuel combustion, producing carbon monoxide and hydrogen, the principal reducing agents for iron oxides. Furnace offgases are cleaned and recovered to supply some of the other plant fuel needs and the collected flue dust is sent to the sinter plant for recycling. 
While the basic principles of the blast furnace process have been known for a long time, many significant improvements have been made in recent years. Among the several technological innovations which have resulted in major gains in blast furnace productivity during the last three decades are:

- Increased furnace size,

- Improved burden preparation,

- Higher blast temperatures,

- Higher top pressures,

- Injection of supplemental fuel, and

- Oxygen enrichment of blast air.

The blast furnace is currently one of the industry's largest production units. The largest blast furnaces in the late 1930's had hearth diameters of approximately 26 feet. This size remained fairly constant until the 1960's when a radical change occurred; furnaces with hearth diameters of 38-45 feet and working volumes in excess of 100,000 cubic feet, were built and are in operation.

Burden preparation also has been improved, both physically and chemically. Physical improvements were derived primarily from more rigorous sizing, while chemical improvements included high iron contents with less gangue, more uniform chemical composition, and the elimination of volatiles.

Since 1950, better hot-blast stove practices have been developed. Presently, hotblast temperatures of $1400^{\circ}-2000^{\circ} \mathrm{F}$ are typical, with most operations automatically controlling blast moisture content via steam additions. Increasing the pressure in the top of a blast furnace significantly increases the rate at which air can be injected into the tuyeres and, hence, the furnace production rate. In the United States, top pressures of 30 to 45 psig are common, but even higher pressures are used in some other countries.

Techniques have also been developed to inject cold hydrocarbon fuels into blast furnace tuyeres to control flame temperature and to substitute for some coke. Until fairly recently, fuel injection was used in the production of more than $80 \%$ of the world's iron, but oil and gas shortages and price increases are discouraging this practice. Natural gas, coke oven gas, fuel oil, pulverized coal, tar and coal-oil.slurries have also been used. Generally, when tuyere-injected fuels are utilized, the moisture content of the blast furnace must be decreased.

According to AISI statistics, in 1979 domestic blast furnaces consumed $1.37 \times 10^{18}$ Btu's of Level 1 energy, or about $45.3 \%$ of the total fuel-derived energy of the domestic iron and steel industry. In terms of a Level 2 energy analysis (fuels and raw materials), blast furnaces consumed $1.38 \times 10^{15}$ Btu's in 1979 .

\section{b. Basic Oxygen Furnace (BOF)}

Since the BOF process was first introduced in the United States in 1954, raw steel production by this methud luas climbed to about 83 million net tone in 1878 , or about 
$60 \%$ of the total U.S. production of raw steel. This growth has come largely at the expense of open-hearth shops, which could not compete economically or environmentally with the BOF.

Oxygen steelmaking processes of commercial significance include the BOF, Stora-Kaldo rotor, and the more recent $Q \cdot B O P, O B M$ and KMS variations. The BOF process is the predominant system in use around the world. In this version, the furnace consists of a cylindrical steel shell closed at one end and lined with basic refractory material. The furnace vessel rotates about a lateral axis for charging and tapping.

Hot metal from the blast furnace is the largest and most important source of iron in the BOF and usually comprises 70 to $80 \%$ of the ferrous charge. The composition of the hot metal and temperature both directly affect the chernistry and thermal balance of the process. Because of the thermal constraints, the upper limit for scrap utilization is generally considered to be $30 \%$ of the metallic charge.

In a typical opcration to produce low-carbun sleel, the furnace is tllted for charging with scrap and hot metal and is then returned to a vertical position. With the injection of oxygen through a lance lowered into the furnace, a visible reaction flame begins to leave the furnace mouth. Lime and fluorspar fluxes are added to the furnacc through an overhead chute. When the carbon content has reached the desired level, temperature readings, slag samples; and refined metal samples are extracted for analysis. Finally, the furnace is tilted to tap the raw steel into a ladle. Carbon, ferromanganese, ferro-silicon, aluminum, and other alloying or modifying agents may be added to the ladle as the tapping proceeds. Occasionally, alloying agents are added to the furnace immediately before tapping, but these are largely confined to such alloys as nickel, copper, and molybdenum, that do not readily oxidize.

An extension of the basic oxygen furnace is the OBM process developed by Eisenwerk Gesellschaft Maxhuette of West Germany. This development has spawned a number of recent innovations or improvements to the BOF, including the Q-BOP, $O B M-S$, and KMS processes. These variations will be discussed in some detail in Section II-7.

\section{c. Electric Arc Furnace}

The general configuration of the electric arc furnace for steelmaking is a shallow. depth, large-diameter cylindrical shell with a dished bottom. The shell is covered with a removable roof through which three graphic electrodes are inserted. The entire shell and roof are lined with high-performance refractories.

Steel scrap is the principal raw material for electric furnace steelmaking. Sponge iron from direct reduction has also been found to be practical for up to $50 \%$ of the metallic charges; if this raw material is available, it is expected to have increased importance in the future.

The capacity of electric arc furnaces has increased from 4 tons per heat in the first U.S. installation (1906) to more than 200 tons per heat in modern electric arc 
furnnces. Operating practice has been improved with the installation of high-powercapacity transformers. With the higher power, melting is more rapid and furnace heat schedules have been decreased to periods of 3 to 4 hours for a complete carbon steel cycle.

A furnace heat cycle begins with the loading of a partial charge to the top of the furnace. The roof is then closed and the electrodes are lowered so that an arc is formed between the electrodes and the charge. After the initial charge is melted, the balance of the charge is put into the furnace and melting and refining proceed to completion of the heat. When target chemistry is attained, the heat is tapped into a transfer or teeming ladle and the remaining slag is dumped from the furnace into a slag pit. The refractory lining is then patched to make the furnace ready for the next heat.

The process is characterized by flexibility of operation and close control of heat chemistry. Therefore, it may be used to produce the full range of carbon and mediumalloy structural steels, as well as specialty alloys, stainless steels, tool steels, and superalloys. In 1979, about 34 million net tons of raw steel, equivalent to $24.88 \%$ of the total U.S. production, were produced in electric arc furnaces.

\section{Blast Furnace Energy Conservation Technology}

\section{a. Description}

Table II-3 presents a profile of energy use in the blast furnace. Coke, which is used to reduce iron oxide and provide heat, is the most expensive form of energy consumed in the blast furnace. The average U.S. practice called for 1,192 pounds of coke per ton of hot metal in 1979 , which represents 1.27 quads for a production of 87 million tons of hot metal. Iron and steelmakers have long devoted considerable time and effort toward reducing the "coke rate" or weight of coke necessary to produce 1 ton of hot metal.

\section{b. Coal Injection in the Blast Furnace}

The injection of auxiliary fuels through the tuyeres is one method of reducing the coke rate effectively. The first fuel to be widely accepted for this purpose was natural gas, which was followed by oil when natural gas shortages began to occur. Depending on present specific blast furnace practice, coal injection can represent either of two possibilities:

- A coke substitute, if no other fuel is presently being injected; or

- An oil or natural gas substitute, if either fuel is presently being injected.

Several plants inject tar, but usually on a very limited scale for technical and economic reasons. Coal would displace tar as well.

Figures II-9 and II-10 depict the coal-injection process, based on systems used by Armco Steel. All the components shown are standard, from the pulverizers to the compressors. The innovation lies in the way the components are used. 
TABLE \|I-3

ENERGY CONSUMPTION IN THE BLAST FURNACE

Item

Iron Ore, Pellets, Sinter

Limestone

Refractories

Coke

Fuel Oil

Tar and Pitch

Natural Gas

Coke Oven Gas

Blast Furnace Gas

OxyyelI

Electrical Energy

Stcam

Byproduct Credit

Blast Furnace Gas
Energy Consumption

(Million Btu per Net Ton Hot Metal)
3.41
0.06
0.06
18.81
0.58
0.16
0.33
0.06
2.71
0.04
0.26
1.20
27.68
$-4.56$

23.12

The coal is first dried with preheated air. It is then pulverized to the same extent required for pulverized coal combustion in steam boilers. It is stored under inert atmosphere $\left(\mathrm{CO}_{2}+\mathrm{N}_{2}\right)$ in a buffer tank slightly above atmospheric pressure. The injection system operates under pressure. A series of standard compressors provides the necessary energy to move the coul through the circuit.

The problem of distributing the pulverized coal uniformly to each of the tuyeres is overcome by proper fluid flow and piping geometry.

The following limitations restrict the flexibility of coal injection:

- Like any other material charged to the furnace, the coal being injected must be of constant quality, in order to facilitate the control of the process. In particular, the amount and composition of the ash influences the hot metal chemistry.

- Up to $28 \%$ of the coke has been replaced by injected coal at Armco. Other experimental furnaces have been operated with even higher rates of substitution. However, incomplete coal combustion becomes a serious problem at such levels; $20 \%$ is considered a practical maximum. This clearly is an area for research. 


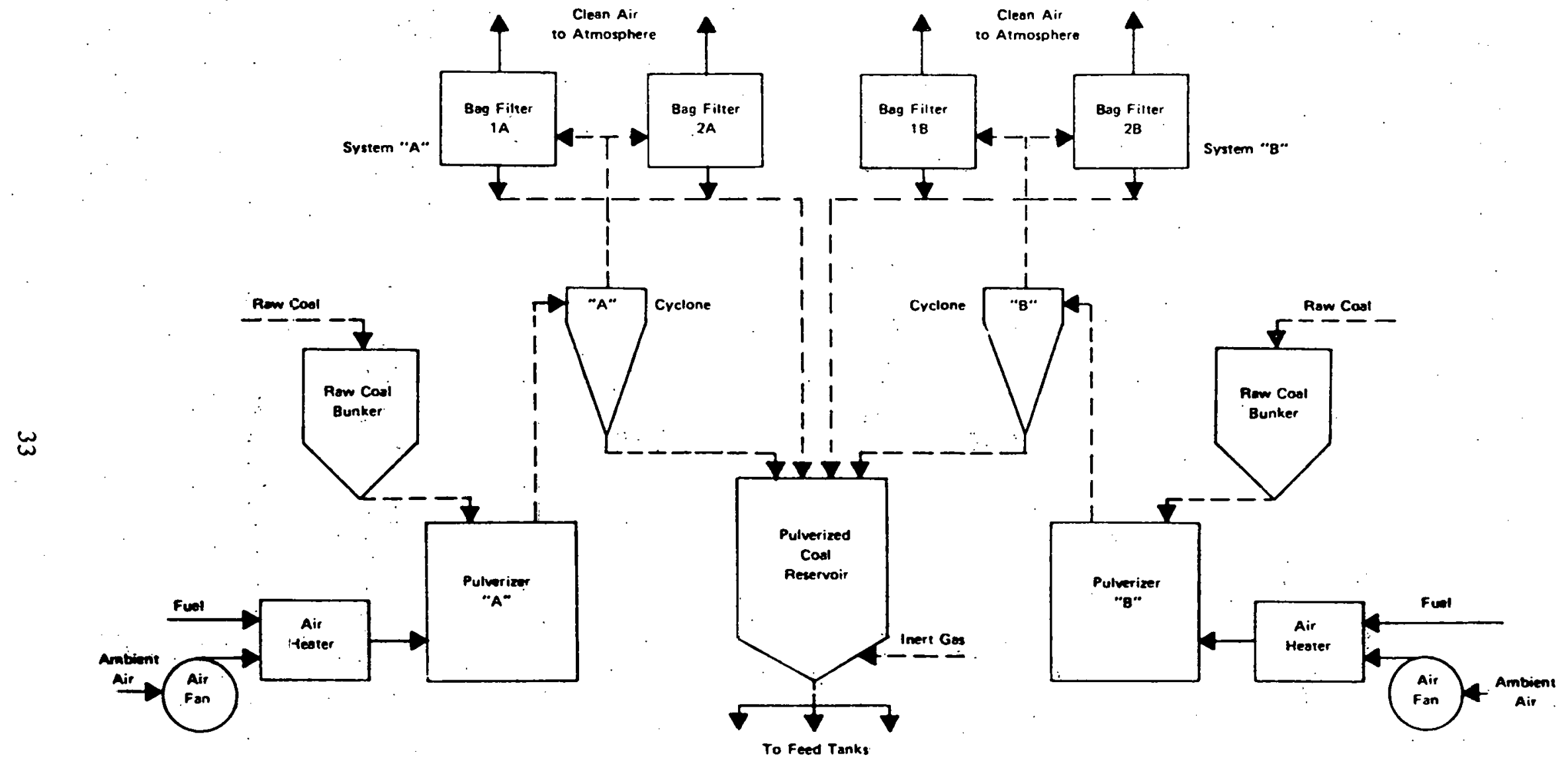

Source: Bull, S.A., J.L. Pugh, J.R. Sexton, "A.rmco Coal Injection," for Presentation and Publication AIME Ironmaking Conference and Proceedings, private communication, 1976.

\section{FIGURE II-9 AMANDA COAL INJECTION - LOW-PRESSURE AIR SYSTEMS PLUS COAL PULVERIZING/COLLECTING}




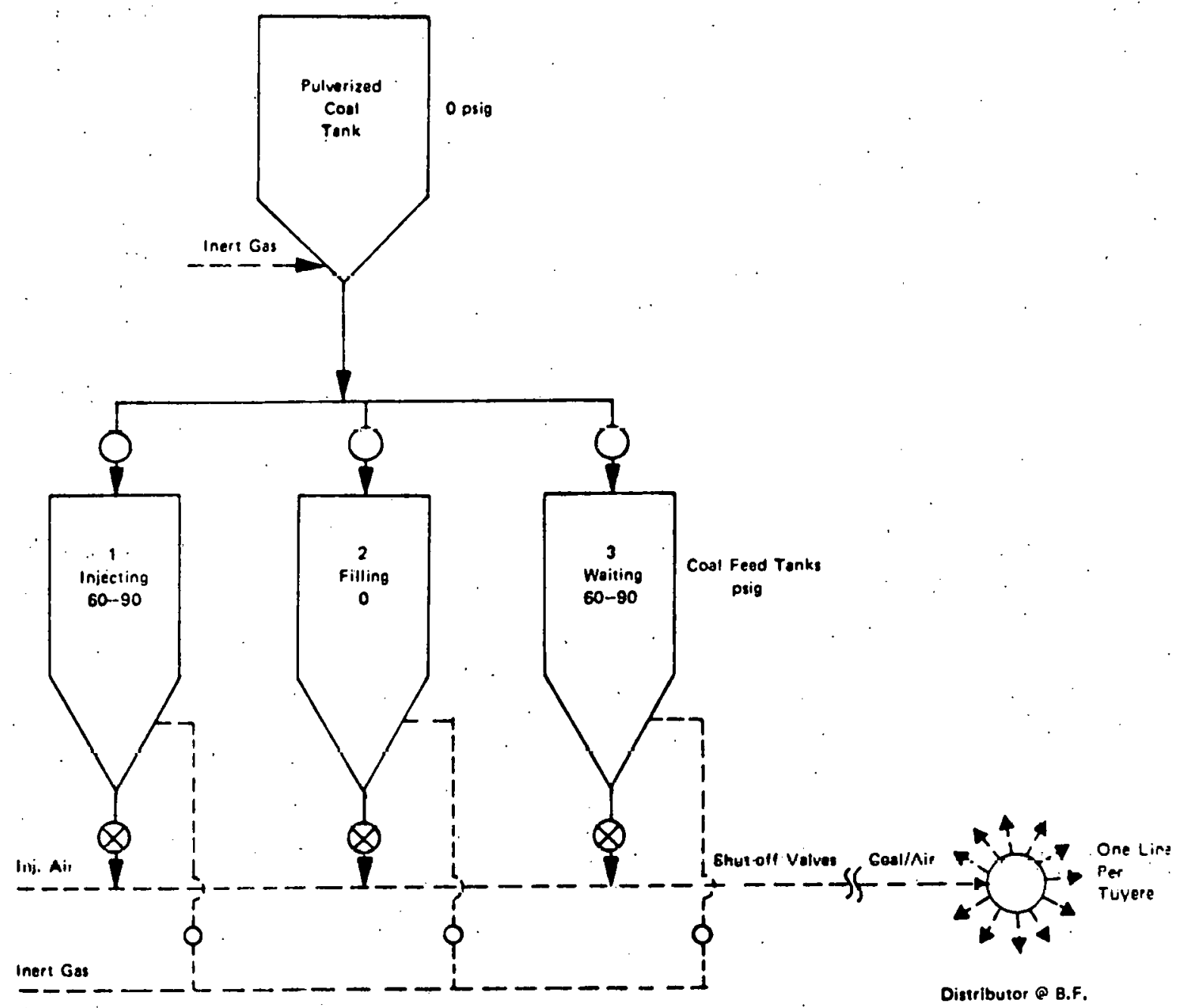

Source: Bull, S.A., J.L. Pugh, J.R. Sexton, "Armco Coal Injection," for Presentation and Publication AIME Ironmaking Conference and Proceedings, private communication, 1976.

FIGURE II-10 AMANDA PRESSURIZED COAL INJECTION SYSTEM 
- The thermal energy obtainable from injected coal varies with its ash content. For a given heat input to the furnace, the replacement of a ton of coke might require 0.91 ton of metallurgical coal but 1.28 tons of higher ash, non-metallurgical coal. The following equation, which was developed by Armco engineers, quantifies this relationship:

Coke/coal replacement ratio $=1.48-(0.666)(\%$ coal ash $/ \%$ coke ash $)$

\section{c. Potential Energy Savings}

The following discussion assesses the potential energy impact of coal injection on the U.S. iron and steel industry. First; the following assumptions are made:

- Blast furnaces operate at the 1979 level of 87 million tons of hot metal production.

- 262 pounds of coal replace 233 pounds of coke per ton of hot metal. This assumes no improvement of present technology.

- All blast furnaces switch to coal injection.

Under these assumptions, 11 million tons of steam coal would replace 10 million tons of coke per year. On one hand, this would lower the national consumption of metallurgical coal by nearly 15 million tons. On the other hand, it would deprive the steel plants of 0.082 quad of coke oven gas, which would have to be replaced by another fuel. Oil is the most likely candidate, which nullifies the energy saving from the process.

Alternatively, one might take the following more realistic approach. That is, less than half the U.S. blast furnaces are presently operated with auxiliary fuel injection. It would probably be realistic to expect that this same fraction of the hot-metal producing capacity would be amenable to coal injection. The total energy saving would then be of the order of 0.11 quad. We have used this figure for the purpose of this study.

\section{d. Present Status of Development}

Coal injection is practiced in the United States by Armco Steel. The first system was installed on the Bellefonte blast furnace of Ashland Works in 1966. and a second system was installed on the Amanda blast furnace in 1973.

Coal injection is more costly than oil injection in terms of capital costs. The operating cost in a blast furnace has been estimated at $\$ 6$ per ton of injected coal, exclusive of coal cost. However, for a new facility having the choice of installing or not installing an injection system, an AISI study indicated that the payback period on a coal injection system would he 3.5 years.

From a technological standpoint, coal injection has been demonstrated only for a narrow range of conditions. In the steel industry's view, a systematic comparison between various grades of coal and with other auxiliary fuels is needed. Unfortunately, production blast furnaces are generally not available for test purposes. 


\section{e. R\&D Needs and Development Costs}

The consensus among the steel companies is that a demonstration program is needed to ascertain the advantages and disadvantages of coal injection. More specifically, a wider range of coal than in the past should be investigated, so that interested companies could gather data on coals available to them. Although two furnaces are now operating with coal injection, these furnaces are not available for research and development purposes.

\section{f. Role of the Federal Government}

A role for the Federal Government may be the sponsorship of a program to demonstrate the feasibility of coal injection with a wide range of coals. Should coal injection be found desirable, further research could be done in the field of coal combustion, in order to lift the present ceiling of $20 \%$ maximum coke replacement.

\section{g. Other Energy-conserving Blast Furnace Concepts}

(1) Injection of Hot Reducing Gases in the Stack - The endothermic reduction of higher iron oxides to $\mathrm{FeO}$ ocoure in the stack of the blast furnace. Partial metallization to iron also takes place and continues toward completion as the charge descends. The ascending gases generated by the combustion of coke in the tuyere zone are therefore cooled and oxidized in the stack. As a result, both their heating potential and reducing potential are depleted.

Injecting hot reducing gases $\left(1832^{\circ} \mathrm{F}\right.$ or higher) in the stack is a way to reduce the coke rate while providing sufficient heating and reducing potential to the gases working in the furnace. These injected gases can be generated externally from fuels other than coke. Gasified coal is a prime candidate; one of the proposals evaluated in this study includes a coal burner with a wide range of potential applications.

A number of preliminary experiments on gas injection have been run over the years. All used oil or natural gas as primary fuels from which hot reduoing gases werc derived.

Among the little published data are those disclosed by Professor Pierre Coheur of the Belgian CRM in 1971 (Arthur D. Little, 1978). Injection of hot reformed natural gas was found to decrease the coke rate of the experimental blast furnace at Ougree. It was also found to be compatible with ordinary fuel injection through the main tuyeres.

The problem has always been to find an economical source of reducing gas at sufficient temperature. The hot reducing gas could be generated from coal, as noted above. The probable net effects would be:

- A shift from coke (metallurgical coal) to steam coal; and

- A slight increase in the total energy consumption on a straight Btu basis.

The impact of such a technology could be of the same order of magnitude as that of ordinary coal injection. Good proposals showing the technical and economic feasibility of this concept should be considered for potential funding. 
(2) Evaporative Steam Cooling - Thic concept involves using evaporative cooling systems generating low-pressure steam to replace once-through or recirculating water systems on blast furnaces. If every U.S. blast furnace were fitted with an evaporative steam cooling system, the total energy generated in the form of low. pressure steam would be less than $80,000 \mathrm{Btu} /$ ton or 0.007 quad per year (based on hot metal production of 87 million tons). The steam is saturated and low in pressure, so it is difficult to use in the blast furnace area. A suitable use is for steam heating. $\dot{A}$. smaller energy saving is that no pumps are required to circulate the coolant through the system.

(3) Conversion of Top Pressure to Electricity - Modern blast furnaces operate under 30 to 45 psi pressure. The gases leaving the top of the furnace must be cleaned, cooled, and reduced to the pressure of the blast furnace gas distribution system. This pressure drop can be used to drive an expansion turbine which can, in turn, drive an electric generator. In this fashion, part of the energy expended by the turbo-blowers in compressing the gas could be recuperated.

Blast furnace gas is collected in the uptake, a manifold located at the top of the furnace. It then flows down a large pipe called the downcomer. The coarser portion of the dust is collected in a dust catcher, where the velocity of the gas is reduced and its direction is changed. A wet scrubber is then used for secondary cleaning. Because of the very abrasive nature of blast furnace dust, expansion turbines have to be located downstream of the wet scrubber.

Both axial and radial turbines have been used for energy recovery systems in Europe and Japan. In axial turbines, the gas flow is parallel to the axis of the machine. To avoid damaging the turbine, the dust content of the gas must be less than 0.004 gram per SCF: The temperature must also be high enough to prevent condensation during expansion in the turbine. In some cases, this necessitates reheating the incoming gases, as they have been cooled in the scrubber. The overall efficiency of the energy recovery drops as a result of this reheating.

In radial turbines, the gas is admitted at the outer edge of the rotor and is directed toward the center. This design alleviates the problems of dust content and water condensation.

All new blast furnaces will operate under high top pressure. However; it will be some time before all the atmospheric pressure furnaces are replaced. Assuming that about $20 \%$ of the U.S. blast furnaces will utilize high top pressure in the coming 5 to 10 years, expansion turbines would save the nation about 0.01 quad per year.

Locating the turbine upstream from the wet scrubber would increase its efficiency. The problem is to select a material and turbine design that will minimize erosion of the blades. This problem may not warrant a special study by DOE, but if there were an opportunity to gain further insight into the problem as part of a more comprehensive program of blast furnace experimentation, its inclusion in the total scope of effort would be wnrthwhile. 
(4) Burden Composition and Distributional Control - In order to provide the blast furnace with an optimal burden, the burden composition and distribution at the top of the furnace are automatically controlled. The computer keeps track of available raw material characteristics, including estimates of water content of coke which are measured on line. Minicomputers have been found to be especially valuable in the sequencing of bell-less (Wurth) tops. While Wurth tops are being placed on new blast furnaces, there may be potential for demonstration of retrofit under U.S. conditions.

\section{Cupola}

\section{a. Description}

The cupola is the most widely used furnace in the iron foundry industry. According to our estimates, there are about 1,000 foundries in the United States which have cupolas. The distribution of the cupolas by melting capacity is as follows:

$\begin{array}{cr}\begin{array}{c}\text { Melting Capacity } \\ \text { (tph) }\end{array} & \text { Percent Dist } \\ <5 & 42 \\ 5-10 & 33 \\ 10-20 & 18 \\ 20-50 & 7 \\ >50 & <1\end{array}$

It is estimated that there are 1400 to 1500 cupolas in the U.S. foundry industry.

In the conventiunal cupula, the off-guses contaln 12 to $25 \%$ carbon monoxide: (CO) with a typical concentration of $16 \%$. The amount of $\mathrm{CO}$ in the off-gases depends. on many factors, including the amount of coke charged and the temperature of the melting zone. To meet EPA regulations, it is necessary to burn the $\mathrm{CO}$ before dis charging the cupola off-gases to the atmusphere. The "afterburner" is the most common method of burning the $\mathrm{CO}$ to meet these regulations. Many of the hot blast cupolas use special burner/recuperator combinations (e.g., the Escher system) to perform this function. These systems also recover the latent and sensible heat of the cupola off-gases and, at the same time, reduce the $\mathrm{CO}$ levels in the stack gases. A large proportion of the U.S. cupolas melting more than 50 to 16 tons per day now use hot blast in order to decrease coke consumption and reduce costs. The cost savings are usually significant on smaller cupolas as well, but the unit capital cost of the preheat system is high. For this reason, smaller companies find it difficult to justify a hot-blast cupola.

The afterburner, which is used to burn the $\mathrm{CO}$ in the cupola off-gases, consumes about 0.10 to 1.0 million Btu's of oil or natural gas in the afterburner per ton of hot metal produced. The wide variation is the result of the type of afterburner, its location, high-or low-stack cupola, operating practice, etc. It is one of the more energy-intensive process steps in a cupola-based iron foundry. 
To eliminate the use of an afterburner and thereby reduce energy consumption in a cupola, Professor A. Draper of Penn State University has proposed the addition of secondary air a few feet below the charge door, at a spot where the temperature is about $1400^{\circ} \mathrm{F}$. The proposed process is expected to permit the carbon-monoxide content of the effluent to be reduced sufficiently to eliminate the need of the afterburner and thereby reduce energy consumption.

\section{b. Potential for Energy Savings}

The amount of energy (natural gas or oil). consumed by the afterburner depends on the type of cupola operation (e.g., low coke or high coke), the capacity of the cupola, as well as other factors. However, as indicated above, a cupola uses 0.10 to 1.0 million Btu's in the afterburner per ton of hot metal produced.

If we assume that all the cupolas, including the ones employing the hot blast concept, implemented Penn State's stack burner concept, and that this concept would eliminate the requirement of the afterburner (this is required to meet EPA's regulations for $\mathrm{CO}$ ), then the adoption of the Penn State stack burner could potentially save, on the average, about 0.5 million Btu's for each ton of hot metal produced.

If we translate these figures into the total energy that could be saved in the United States if this concept were implemented on all cupolas, we estimate that up to 0.01 quad of energy could be saved - all in the form of natural gas or oil.

It is important to note that a large proportion of the larger cupolas in the United States use the hot-blast system. The use of the Penn State concept on these cupolas is limited. Further, the Escher recuperative system, which is a sort of a competitor to the Penn State stack burner, has already been installed on about $5 \%$ of the U.S. cupola capacity with good success. The Penn State concept is also unlikely to be used on the cupolas which have already adopted this technology.

\section{c. Present Status of Development}

The Penn State stack burner is still in the development and testing stage; as of this date, no equipment has been built on a commercial acale. According to Penn State, it has conducted preliminary test wrok on its 24-inch experimental cupola, as well as done some test work on a 34-inch ID cupola in Tioga's foundry in Owego, New York, and on Abex foundry's 60-inch ID cupola. We understand that the Modern Equipment Company has designed a Penn State stack burner for commercial testing at the Tioga foundry.

According to Professor A. Draper of Penn State, there are plans to test the system on cupolas larger than the one at Tioga, i.e., on the 60-inch cupola at Abex's foundry in Pennsylvania and the greater than 100-inch cupola at Griffin Pipe's New Jersey plant. However, these tests will follow only after the test work at Tioga.

\section{d. R\&D Needs and Development Costs}

One of the key questions to be answered in evaluating this technology is: will the Fenn State stack burner lowcr the CO content in the stack geses to a sufficiently low 
level to eliminate the use of an afterburner? This has yet to be proven on a commercial scale. Based on our discussions with both Penn State and Modern Equipment, the test work done to date resulted in the $\mathrm{CO}$ content being lowered to only about 2 to $5 \%$. Therefore, more test work is necessary before this concept can be proven capable of eliminating the afterburner on a commercial-scale cupola.

The concept will also have to be tested and proven on cupolas of various sizes and types (short stack, tall stack, hot blast, cold blast, etc.) to develop sufficient data on the basis of which industry would be willing to accept it without skepticism.

We believe that at least $\$ 200,000$ to $\$ 500,000$ more in development costs will be necessary to prove this concept.

\section{e. Role of the Federal Government}

Before the Penn State stack burner is proven, it will have to be tested and proven on a commercial scale to ascertain its potential for eliminating the afterburner, as well As its energy-conservation capability. It is extremely important that the monitoring and reporting of the performance of the test work be done by somebody independent of Penn State, so that the results and performance of the unit under test in relation to competing systems represents objective conclusions.

The Department of Energy must also carefully review the other alternate approaches to eliminating the afterburner (e.g., Escher System, Modern Equipment's CO by-pass burner, etc.). It is unlikely that the Penn State stack burner is ideally suited (technically or economically) for all types of cupola operations and, in many situations, the other methods might prove to be more suitable in achieving the energyconscrvation objective.

\section{Direct Reduction}

\section{a. Description}

Direct reduction is defined as any process in which metallic iron is produced by the reduction of iron ore, or any other iron oxide, below the melting temperature of any malerials involved. The product of a direct reduction process (DR process) is called direct reduced iron (DRI). Direct reduction processes can be grouped into three major categories:

(1) Those using solid reductants in granular beds;

(2) Those using gaseous reductants In granular beds; and

(3) Those using gaseous reductants in fluidized beds.

Table II-4 lists well known direct reduction processes. 
TABLE \|-4

\section{PRINCIPAL DIRECT REDUCTION PROCESSES}

\section{Solid Reductants in Granular Beds}

(Continuous)

Krupp-Renn

Basset

Orcarb

Strategic Udy

$R-N$

SL/RN

Krupp

Kawasaki

S D R

$S P M$

D R C

Dwight-Lloyd-

McWane

Heat Fast

Echeverria

Kinglor-Metor

(Batch)

Hoganas
Gas Reductants

in Granular Beds

(Continuous)

Wiberg

Republic

Finsider

Armco

Purofer

Midrex

ACCAR

Nippon Steel
Gas Reductants

in Fluidized Beds

(Continuous)

Stelling

Novalfer

Fior

H.I.B.
(Batch)

Madaras

HyL
(Batch)

H-Iron

Source: Sabakin, 1980.

Direct reduced iron has successfully provided a substitute for scrap in the electric arc furnace. In addition, the DRI product is free from tramp elements such as copper, zinc, tin, chromium, molybdenum, tungsten, and others that are usually present in scrap. DRI can also be used in basic oxygen furnaces and open-hearth furnaces, or as a partial substitute for ore in blast furnaces.

The three commercially demonstrated direct reduction processes in the United Stules use liydiuciarbon fuclo (c.g:, natural gas or naphtha) in vertical-shaft furmaces. The total capacity of these plants is estimated at 1.1 million short tons of product per year. The exhaust gas from the furnaces has a maximum fuel value of $70 \mathrm{Btu}$ 's per SCF and is presently flared. (Typical gas volumes are 57,000 SCF per minute at a temperature of $1200^{\circ} \mathrm{F}$ for a furnace with a capacity of 400,000 tons per year production.) 


\section{b. Energy Conservation Potential}

The existing direct reduction plants could be operated on gasified coal fuels instead of the critical hydrocarbon fuels now used. An estimated $12 \times 10^{12}$ Btu per year of critical fuels could be saved by this fuel change. However, since this process is very sensitive to fuel costs, the direct reduction plants now operating in the United States may be shut down as uneconomical within five years. We believe that the present relatively high cost of gasified coal fuel would not change the economic picture for gasified fuel direct reduction processes.

The steam/coal-fired direct reduction processes would save metallurgical coke normally used in the blast furnace process but would consume more total energy. Table II-5 shows that the likely direct reduction-electric arc furnace route to steel consumes $56 \%$ more energy than the coke oven-blast furnace-BOF' route. 'The only advantage of the direct reduction route is in replacing a given number of Btu's from metallurgical coke with a larger number of Btu's from steam rnke and electricity.

\section{c. Present Status of Development}

The gas-based processes such as the Midrex, HyL, and Armco are commercially developed. We expect this technology to be adopted where natural gas is available. Steam/coal-based processes such as the SL/RN process (Stclco Lurgi, Republic Steel and National Lead), the Kawasaki process, and the Krupp-Renn processes have had technical demonstrations. However, coal-based direct reduction processes need more commercial demonstration and testing before they will be accepted for use by the steel industry.

Another approach is to tie in coal gasification to a proven gas-hased direst. reduction process. We understand that such processes are being planned.

\section{d. $R \& D$ Needs and Development Costs}

Wo undorotand that the U.S. Stccl Corporation is undertaking an evaluation of direct reduction technology and economics for the Department of Energy. This evaluation will cover existing and new technology. The study should provide a data base for comparison of energy requirements of various processes.

\section{e. Role of Federal Government}

Funding of a direct reduction demonstration should be done only afler careful consideration, because there are processes that have been commercially demonstrated. From an energy standpoint, the main advantage of direct reduction technology is the possibility of using coal either directly or by a lit-in will cuul gasificution. Fuel costs and availability are likely to be the constraints to adoption of direct reduction technology. 


\section{ENERGY REQUIREMENTS OF THE CONVENTIONAL AND DIRECT REDUCTION STEELMAKING ROUTES (million Btu per ton of steel)}

A. Direct Reduction

Kiln

Coal

10.96

Electric Power ${ }^{\mathrm{a}}$

0.41

Electric Arc Furnace

Electric Power ${ }^{\mathrm{a}}$

6.30

Total Production

17.67

Pollution Controls

Air: Kiln (electric power)

0.036

EAF (electric power)

0.487

Water: Kiln (electric power)

Total Pollution

Total:

B. Base Line

Coke Oven

Blast Furnace

Basic Oxygen Process ${ }^{b}$

(0.13)

Total Production

Pollution Controls

\begin{tabular}{|c|c|}
\hline Air (electric power) ${ }^{a}$ & 0.34 \\
\hline Water (electric power) $^{a}$ & 0.08 \\
\hline Water (fuel) & 0.25 \\
\hline
\end{tabular}

Total Pollution

Total:

a. $1 \mathrm{kWh}=10,500 \mathrm{Btu}$ fuel equivalent at power source.

b. Includes $0.44 \times 10^{6}$ Btu credit for $\mathrm{CO}$ recovery.

Source: Arthur D. Little, Inc., 1976. 


\section{External Desulfurization}

\section{a. Description}

The trend in blast furnace operation in the United States during the last 20 years has been to increase the degree of burden preparation in order to decrease coke consumption. As the use of highly beneficiated iron ore pellets has grown, blast furnace slag volumes have declined. At the same time, the sulfur in coke has gradually increased and the blast furnace hot metal has also tended to increase. Control of alkali in the blast furnace has required the use of leaner slags and has also resulted in increased sulfur in hot metal. The requirement to control sulfur at the blast furnace (i.e., in hot metal) has increased, because the basic oxygen process, the predominant steelmaking route utilizing hot mteal, has a limited ability to remove sulfur.

Consistent predictable attainment in the BOF of low sulfur levels, particularly 0.15 and $0.01 \%$ sulfur maximum, represents a formidahle task and requires strict control and preparation of the charge. All charge materials-hot metal, blast furnace slag brought by hot metal, scrap and fluxes-are all sources of sulfur. External desulfurization of blast furnace hot metal is practiced for attainment of 0.01 to $0.015 \%$ sulfur BOF tap level. If a $0.005 \%$ sulfur BOF steel (rather than steel) is consistently required, external desulfurization of steel is necessary.

The energy savings associated with external desulfurization of hot metal, enhanced desulfurization during BOF steelmaking, and external desulfurization of steel relate to the fact that high-sulfur hot metal can be made in a more energy-efficient manner in the blast furnace. Consequently, we have examined desulfurization of hot metal in greater detail.

External desulfurization of hot metal is practiced in order to salvage otherwise unusable hot metal ( 0.04 to about 0.02 sulfur) and for the preparation of low-sulfur hot metal for the BOF. Desulfurization of hot metal is done when required; it is not done on every torpedo car or ladle of hot metal charged to the basic oxygen furnace. For example, at Jones and Laughlin, Cleveland Works, approximately 20-30\% of the hot metal is desulfurized and is typically used in $40-60 \%$ of the BOF heats (Orton, et al., 1977). The practice is to desulfurize when necessitated by the sulfur content of hot metal and the sulfur requirements of steel to be produced from it.

The location for treatment, method for contacting reagent and iron, reagent selection and means of slag control are factors very dependent on:

(1) Plant conditions and the preparatory planning in the layout of the blast furnace-steelworks combination;

(2) Capacity objectives - high throughput, lower cost systems generally involve major capital outlays; and

(3) Low-sulfur attainment targets.

Table II-6 lists major hot metal desulfurization processes in use. 
TABLE \|-6

HOT METAL DESULFURIZATION PROCESSES.

\begin{tabular}{|c|c|c|c|c|c|}
\hline Type and Treatment Mode & Basic Equipment & Reagent & Advantages & Disadvantages & Country of Use \\
\hline $\begin{array}{l}\text { Blast Furnace Runner } \\
\text { - Continuous stirrers }\end{array}$ & $\begin{array}{l}\text { Paddle stirrers in } \\
\text { troughs }\end{array}$ & Carbide, soda & Simple, cheap & Poor control, smoke & Japan, Germany, UK \\
\hline Sub-Batch Dunking (mag-coke) & Stems, counterweights & $\begin{array}{l}\text { Mag-coke, } \\
\text { Mag-dolomite }\end{array}$ & $\begin{array}{l}\text { Low capital cost, } \\
\text { simple, reproducible }\end{array}$ & $\begin{array}{c}\text { Slow, high cost } \\
;\end{array}$ & World-wide \\
\hline - Injection & Lances, dispensers & $\begin{array}{l}\text { Powders-mag, lime, } \\
\text { carbide, } \mathrm{Mg} \cdot \mathrm{Al} \\
\text { alloys }\end{array}$ & $\begin{array}{l}\text { Fast, controllable, } \\
\text { lowest cost }\end{array}$ & $\begin{array}{l}\text { High capital cost, } \\
\text { operator training }\end{array}$ & $\begin{array}{l}\text { World-wide, most } \\
\text { prevalent technique }\end{array}$ \\
\hline $\begin{array}{l}\text { Transfer ladle } \\
\text { - Pouring and/or mixing }\end{array}$ & None & Soda ash & Cheap, simple & $\begin{array}{l}\text { Unable to reach low } S \\
\text { variable results, smoke }\end{array}$ & $\begin{array}{l}\text { World-wide for } \\
\text { salvage }\end{array}$ \\
\hline - Dunking (mag-coke) & Stems, counterweights & Mag-coke & Low capital cost & $\begin{array}{l}\text { Charging interference, } \\
\text { fume }\end{array}$ & Few shops - Japan, U.S. \\
\hline $\begin{array}{l}\text { - Stirrers (K-R, } \\
\text { Reinstahl, Stora) }\end{array}$ & $\begin{array}{l}\text { Mechanical paddles, etc. } \\
\text { etc. to create thcrough } \\
\text { mixing }\end{array}$ & $\begin{array}{l}\text { Carbide, lime, } \\
\text { soda ash }\end{array}$ & $\begin{array}{l}\text { Best for ultra low } \\
\text { sulfur }\end{array}$ & $\begin{array}{l}\text { Interference, high cost, } \\
\text { slag-off before and after }\end{array}$ & Japan, Germany \\
\hline - Injection & Lances, dispensers & $\begin{array}{l}\text { Powders-carbide, } \\
\text { lime, soda }\end{array}$ & $\begin{array}{l}\text { Lower cost than } \\
\text { stirrers }\end{array}$ & $\begin{array}{l}\text { Interference, cannot blend } \\
\text { costs, slag-off before and } \\
\text { after }\end{array}$ & Germany \\
\hline
\end{tabular}

"Basic reference is the Proceedings of the McMaster University Symposium on External Desulfurization of Hot Metal, W.K. Lu, Editor, 1975.

Source: (Orton, et. al., 1977). 
For low-sulfur operations, the hot metal treatment methods selected by most plants have been designed either for use at a site between the blast furnace and the steel plant in subs (submarines, torpedo car) or open ladles, or in a transfer ladle between the subs or mixers and the BOF vessels. The latter alternative, although in large-scale use in Europe and Japan, is ruled out in most U.S. shops, except for very intermittent use, because the charging bays in BOF shops, unless designed for this specific purpose, cannot support the added activity.

The transfer ladle treatment systems are generally limited by cost and throughput considerations to the "low-sulfur" work, whereas the objectives often include extensive salvage treatment of high-sulfur iron. Hence, in most cases, where external desulfurization has been added to an existing blast furnace-BOF complex, sub: desulfurization techology has been selected.

The advantagee of treatment prior to delivery of iron to a BOF ehop include:

- Soparation of funotione, leading to lobe oluttor in the charging bay;

- Flexibility in extending desulfurization capacity by "blending down" off analysis hot metal with intentionally overdesulfurized hot metal batches; and

- Ease in preparing the full charge for extra low-sulfur heats.

All hot metal desulfurization processes require intimate contact between the iron and the reagent and, to a certain extent, the separation of sulfur-rich blast furnace slag that accompanies the hot metal.

The reagent and introduction method selection depends on the plant objec. tives - batch processes such as mag-coke offer minimal capital cost, but are relatively slow and costly per treatment. The injection technique is accepted as fast, reliable, and less costly per treatment, although injection stations are expensive to install. At the present, most steel plants rely either on magnesium- or calcium carbidebased reagents for low-sulfur work ( 0.015 or less in hot metal). With exceptionally clean hot metals, in a few instances lime alone is used.

\section{b. Energy Conservation Potential}

External desulfurization has been viewed as a means of correcting for the increasing sulfur content of fuels used in the blast furnace. The objective is to prevent the reduction in capacity and increase in energy use that would be required if desulfurization were done in the blast furnace by introducing more lime. The latter would increase slag volume and basicity, but would also increase coke and injected fuel consumption. 
In 1978, Arthur D. Little, Inc., estimated the potential energy saving attributable to external desulfurization from $0.04 \%$ sulfur in hot metal to $0.02 \%$ sulfur at 0.9 million Btu per ton of hot metal, using either calcium carbide or mag-coke. However, others have estimated 0.82 million Btu per ton of hot metal for the same starting sulfur content and percentage removed using mag-coke.

In addition to the energy balance between fuel savings and desulfurizing reagent, there is approximately a $50^{\circ} \mathrm{F}$ temperature drop in the hot metal during desulfurization. This energy loss is small ( 1670 Btu/ton of hot metal), but it must be accommodated in subsequent steelmaking operations. Some of the data on external desulfurization tend to confuse the picture, because when sulfur levels are higher, more reagents are required for the same blast furnace operating practice; thus, there is no comparison between the above and what the blast furnace energy consumption would have been at these higher sulfur levels if sulfur removal were effected in the blast furnace. The indications are that the energy savings are about 0.86 million Btu per ton of hot metal.

The major long-range purposes of external desulfurization are to:

(1) Extend the domestic resources of coking coal (which would mean highsulfur coke and more sulfur in the blast furnaces); and

(2) Prevent the increase in energy consumption that would occur if desulfurization were to be done in the blast furnace.

As a rough indication of the annual energy saving, the amount of hot metal produced in 1979 multiplied by 0.86 million Btu per ton gives 0.075 quad.

\section{c. Present Status of Development}

A number of hot metal desulfurization processes are in use. Thus, the technology for hot metal desulfurization has been demonstrated.

\section{d. $R \& D$ Needs and Developmental Costs}

It would be advisable to develop and demonstrate fully external desulfurization as a regular procedure for every ladle of hot metal produced, for the following reasons:

- To establish the extent of permissible sulfur content of metallurgical coke. Many high-sulfur coals have good coking qualities. With external desulfurization, some of these coals could be used to make metallurgical coke. If the sulfur specifications on good coking quality coals could be relaxed, the U.S. reserves of coking coal could be greatly extended.

- To determine the best desulfurization practice and the preferred reagent for higher sulfur levels in the hot metal to be treated.

- To establish capital requirements, operating costs, and the effect on energy consumption for production of low-sulfur hot metal. 
Of the remaining two approaches, enhancing the kinetics of desulfurization is economic as well as conducive to energy conservation. An understanding of the desulfurization reaction will require knowledge of the mechanism of the reaction and understanding of factors that determine the reaction rate. In addition, $\mathrm{CaF}_{2}$ has been used as a slag conditioner that enhances desulfurization. Economic and environmental considerations are forcing steelmakers to find substitute materials.

Such research will lay the foundation for enhancing the desulfurization of steel. If acceleration of the desulfurizing reaction is achieved, savings in operating and capital costs are possible as future benefits. The research projects identified are estimated to cost about $\$ 100,000$ to $\$ 200,000$ per year over a time frame of 2 to 3 years.

\section{e. Role of the Federal Government}

External desulfurization of hot metal is a demonstrated technology and is practiced in various parts of the world. Because of the quality of raw materials and more stringent specifications on sulfur in steel, it is likely that external desulfurization will be increasingly required. Most desulfurizing agents are very energy-intensive. The national energy impact of various desulfurization technologies should be assessed, with a view to identifying lower energy use systems. Fundamental research in desulfurization processes in BOF, Q-BOP steelmaking aimed at understanding and enhancing the desulfurization process is very desirable.

\section{BOF Off-gas Utilization}

\section{a. Description}

In basic oxygen furnace steelmaking, oxygen is blown into the vessel containing hot metal and scrap. The reactions of the oxygen with silicon, manganese, carbon, and iron in the hot metal produce the heat required to melt the scrap. While reactions with the other elements produce solids that eventually enter the slag phase, the reaction with carbon produces carbon monoxide; about $10 \%$ of this gas is oxidized to carbon diuxide as il evulves frum lle BOF vessel and reaches a lemperalue of aliuul $2700^{\circ} \mathrm{P}$. The off-gas possesses both fuel value and sensible heat.

In most BOF installations in the United States, the exhaust gases are collected in open hoods over the vessels. Considerable air infiltration occurs, and the off-gas burns in the hoods. Flame temperature of about $3000^{\circ} \mathrm{F}$ are obtained. The hoods are either steam-cooled or water-cooled, causing the gas temperature to drop to about $1850^{\circ} \mathrm{F}$. In some plants a part of the heat from the burning off-gas is recovered as steam by heat transfer to the water-cooled hood or by radiant-heat transfer. After the gases have been further cooled and cleaned, they are released to the atmosphere.

Two major types of gas cleaning systems are used for dust removal from BOF offgas: (1) electrostatic precipitators and (2) venturi scrubbers. In each case, water is used to cool the gas to temperatures that can be handled by the gas-cleaning system.

Most of the sensible heat is removed from the combusted gases by injecting a water spray, which is rapidly vaporized by the hot gases. The heat removed by. 
vaporization of the water spray is wasted. Typically, when steam is generated and utilized, the energy recovered from the off-gas is estimated at 150,000 to $250,000 \mathrm{Btu}$ per ton of steel.

Energy contained in BOF off-gases can be utilized in two ways:

- BOF gas recovery (suppressed combustion system) in gas holders for use within the steel mill, e.g., enrichment of blast furnace gas, boiler fuel, fuel for lime kilns, soaking pits or reheat furnaces, blending with coke oven gas, fuel for scrap preheat; or

- Installation of waste heat boilers with complete combustion systems.

In the United States, there is currently little economic incentive to improve steam-generation efficiency from BOF off-gas over that already attainable with watercooled or steam-cooled hoods. Some steel plants simply have no need for additional steam, particularly steam that is generated only intermittently. Even in plants where steam is needed, the capital and operating costs of installing large boilers over the BOF vessel would likely exceed the cost of operating conventional steam boilers. Only drastic increases in fuel prices above even the present high levels would make BOF boilers economically attractive in the United States.

Of the approximately 38 U.S. plants that have BOF's, 9 have boilers, and the steam is utilized in 7 of these. The 9 plants with boilers represent a capacity of about 29 million tons; those with boilers and utilizing the steam represent a capacity of about 22 million tons (EPA, 1976). Information was not readily available on the size of the boilers and the amount of heat recovered.

In Europe and Japan, large boilers have been installed over some BOF furnaces to produce steam more efficiently. Assuming boiler efficiencies of $80 \%$, it should be possible to recover 0.5 million Btu per ton of steel. The installation of such boilers is favored in locations where fuel prices are high and the steel plant needs additional steam-raising capacity; the cyclic output of the waste heat boilers can be integrated into a larger steam system.

In this section we have examined the recovery of carbon monoxide (CO) in BOF off-gas using suppressed combustion systems. The schemes for the collection of basic oxygen furnace off-gas utilize a closed-hood system over the BOF vessel so that the combustion of $\mathrm{CO}$ is suppressed. The gas volume handled in suppressed combustion systems is one-third to one-seventh that handled in complete combustion systems. As a result, the gas cleaning system is more compact. Figure II- 11 is a schematic of a BOF off-gas recovery system.

The collected gas is potentially valuable as a low-sulfur fuel which can be used to augment the gaseous fuel supply within the plant. At both the beginning and the end of a blow in a partial-combustion system, the $\mathrm{CO}$ emitted from the vessel is burned; this is done to form a plug of inert combusted gas for flushing out the ductwork and preventing the formation of an explosive mixture of $\mathrm{CO}$ and air. For this reason, it is 


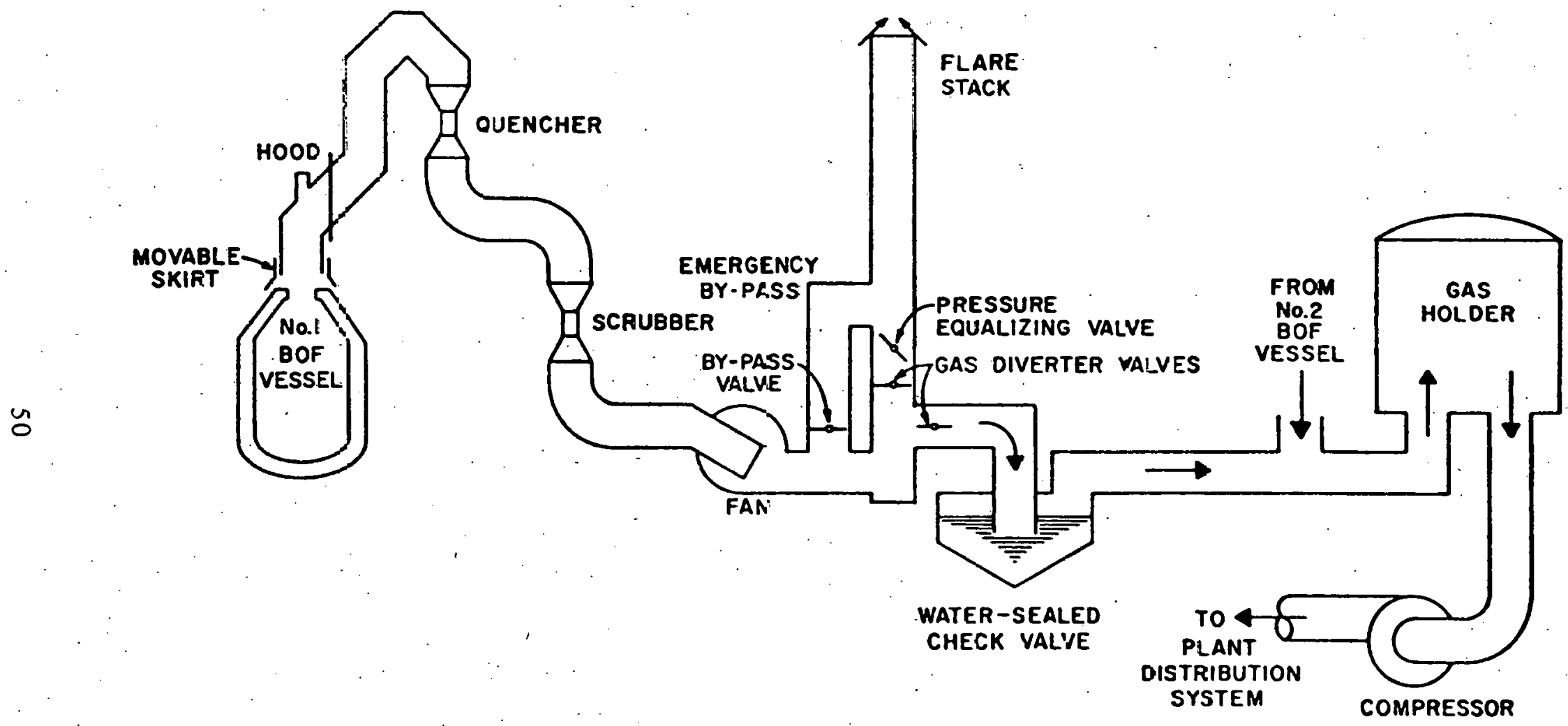

Source: A.ISI, 1976. 
practical to collect the off-gas for only a limited portion (usually half) of the blow. During the collection period, the $\mathrm{CO}$ content of the gas is relatively constant. About $60-90 \%$ of the gas volume is collected.

Other advantages claimed for the closed-hood system include:

(1) Increase in steel yield of about 1 percent, due to lower slopping losses, and

(2) Easier dust collection, as dust particles in the non-combusted off-gas are generally coarser and less oxidized.

The major suppressed combustion systems are the $O G$ system and the IRSIDCAFL system. In the United States, these systems are licensed and sold by Chemico (OG) and Baumco and American Filter (IRSID-CAFL).

\section{b. Potential for Energy Savings}

The oxygen consumption in BOF steelmaking ranges from 1500 to 2400 SCF per ton of steel. On the basis of a material balance (Healy, 1966), about $60 \%$ of the usage, or 900 to $1440 \mathrm{SCF}$, is for the oxidation of carbon in the hot metal to carbon monoxide. Hence, the carbon monoxide generated ranges from 1800 to $2880 \mathrm{SCF}$. In practice, about $10 \%$ of the carbon monoxide burns in the vessel. The carbon monoxide that could potentially be collected falls in the range of 1620 to 2590 SCF having a fuel value of 0.52 to 0.83 million Btu per ton of steel, based on 321 Btu per SCF for the combustion of $\mathrm{CO}$ to $\mathrm{CO}_{2}$. In addition, the temperature of the off-gas is $2700^{\circ} \mathrm{F}$; therefore, the total energy content including the sensible heat ranges from 0.61 to 0.98 million Btu per ton steel. The gas volumes handled in suppressed-combustion systems are one-third to one-seventh of those handled in complete-combustion systems, resulting in an electrical energy saving of the order of $6 \mathrm{kWh}(0.06$ million Btu) per ton of steel.

The potential for energy savings in BOF off-gas recovery is:

(1) Production of byproduct $\mathrm{CO}$-rich fuel that could replace natural gas or oil on the order of 0.61 to 0.98 million Btu per ton steel; and

(2) Electrical energy savings of the order of 0.06 million Btu per ton steel.

If all plants were to adopt BOF off-gas recovery, a potential saving of $0.56-0.87$ quad is possible (based on BOF production of 83 million tons).

If the off-gas recovery system is designed for collection around peak carbon monoxide generation, approximately 2500 SCF per ton of steel is collected, and the gas has a heating value of 220 Btu per SCF. This represents a fuel value of 0.55 million Btu per ton steel. Developments in suppressed-combustion systems have made it possible to collect off-gases for almost the entire blow. Per ton of steel, this results in the collection of approximately 3600 SCF of gas with a heating value of $185 \mathrm{Btu}$ per SCF, and represents a fuel. value of 0.67 million Btu per ton of steel. Further savings of energy can be realized if the sensible heat in the off-gas is recovered. 


\section{c. Present Status of Development}

The technology for gas collection is fairly well established. About 175.200 suppressed-combustion units are either in operation or being built in Japan, France, the United States, the United Kingdom, Belgium, and U.S.S.R. A number of Japanese and European plants have installed gas holders, controls, and compression equipment to recover gas from suppressed-combustion hood systems. By contrast, the United States has five BOF shops with suppressed-combustion hood systems, all of which flare the recovered carbon monoxide. Shops having suppressed-combustion hood systems represent an annual capacity of $\mathbf{1 8 . 2}$ million tons of steel.

\section{d. R\&D Needs and Development Costs}

The technology for BOF off-gas collection and storage has been demonstrated. An area of research would involve development of ways of better utilizing the sensible heat in the off-gas. This research could be done by equipment manufacturers, supported by steel companies, and could be encouraged by DOE support. Benefits from such research would be realized in the longer term (i.e., up to 10 years).

\section{e. Role of the Federal Government}

The constraints to adoption of BOF off-gas collection, storage, and utilization are mainly economic, and an appropriate role of the Federal Government may be to provide financial incentives.

\section{Scrap Preheating in Oxygen Steelmaking}

In a typical BOF operation, the only source of energy required for steelmaking is hot metal produced in the blast furnace; the sensible heat of the hot metal provides about $50 \%$ of the input energy, while the combustion of carbon contained in the hot metal (normally about $4 \%$ by weight) provides approximately $20 \%$; the remaining $30 \%$ of the input energy is supplied by the combustion of silicon, iron, manganese, and phosphorus.

Booauso tho rofining of hot motal in a BOF io highly oxothormio, forrous oorap (or a substitute, such as direct reduced iron pellets or ore) must be added as a coolant. However, since external sources of energy are not provided on a typical BOF, the scrap fraction of the charge is set by the thermal balance in the furnace. Sufficient scrap must be added to prevent meltdown of furnace linings, but not so much as to freeze the bath. In general practice, about $28 \%$ of the metallic charge is scrap. To increase this fraction of scrap in the charge and thereby conserve energy expended in blast furnaces to produce hot metal, it has been suggested for many years that the BOF scrap be preheated.

\section{a. Description}

Scrap usage in a BOF can be increased by (1) reducing the heat losses of the process; (2) adding additional fuels, raising the temperature of any or all of the reactants; or (3) recovering heat from the end products in such a way that it can be used. Of these possibilities, only scrap preheating has been used to any significant extent, most notably by the Alan Wood BOF shop (now closed). On a limited scale, the Alan Wood shop demonstrated that scrap charge ratios up to $45 \%$ could be achieved with scrap preheating. 
However, significant disadvantages are associated with scrap preheating in BOF vessels, which is usually accomplished with an oxy/fuel top lance. The economics of this technique are questionable because of severe refractory lining wear (with resulting high refractory costs), and because of significantly decreased furnace availability. Furthermore, the relatively low-heat transfer efficiency resulting from the top burner arrangement (less than $50 \%$ ) adds significant fuel costs.

To overcome the difficulties associated with BOF scrap restrictions and to improve overall meltshop efficiency, a number of modifications to the basic BOF have been proposed and recently installed on large-scale units. The first of these, developed and tested during the early 1970's, was the OBM process (Oxygen Bottom Maxhuette), named the Q-BOP process by U.S. Steel. In this process, oxygen is injected into the bottom of the converter through an annulus of gaseous hydrocarbon to protect the tuyere; the OBM process has proved successful in many respects, probably the most significant of which is the close approach to equilibrium that can be obtained compared to top blowing. However, this closer approach results in less iron oxidation (and therefore higher yields) which, in turn, decreases the energy available for scrap melting, since the combustion of iron is exothermic. On the average, the scrap melting capability of the OBM/Q-BOP is lower than a typical BOF by about 2 to $4 \%$.

Two principal methods have been used to increase the scrap capacity of the OBM. The first of these involves the use of the bottom tuyeres as oxy/fuel burners. However, these tuyeres, with their annular gaps designed for a propane flow equal to about $3 \%$ or less of the oxygen flow rate, cannot be used at practical pressures for the much higher flow rates required to achieve a sufficiently large heat input rate. Hence, long time periods are required for scrap preheating and furnace productivity is lowered. (Preheat efficiencies of about $60 \%$ can be obtained.) The second method involves charging scrap together with coke. An oxygen blow through the bottom tuyeres is used prior to charging hot metal to combust the coke rapidly and provide heat throughout the charge. Although relatively small-scale tests indicated an improvement of about $8 \%$ in the scrap change weight (from 25 to $33 \%$ ) with a preheating efficiency of $70 \%$, tests in 200 -ton vessels have not been entirely successful, probably because of uneven coke distributions.

To avoid these problems, Maxhuette developed the OBM-S process (the "S" stands for increased scrap melting capacity). In this system; the annular gap for hydrocarbon flow will permit a sufficiently large flow of liquid fuel for short preheating times. Alternatively, gaseous hydrocarbon is injected during the regular oxygen blow. Combined with the bottom tuyeres are two or more side tuyeres for oxygen injection to promote complete carbon combustion. A schematic of an OBM-S converter is given in Figure II-12. Demonstration tests have shown that the fuel efficiency of scrap preheating is belween 65 and $75 \%$ and that scrap charges of $48 \%$ are feasible, Scrap charges can be further increased by the injection of carbon through the bottom tuyeres (Schempp, 1979). 


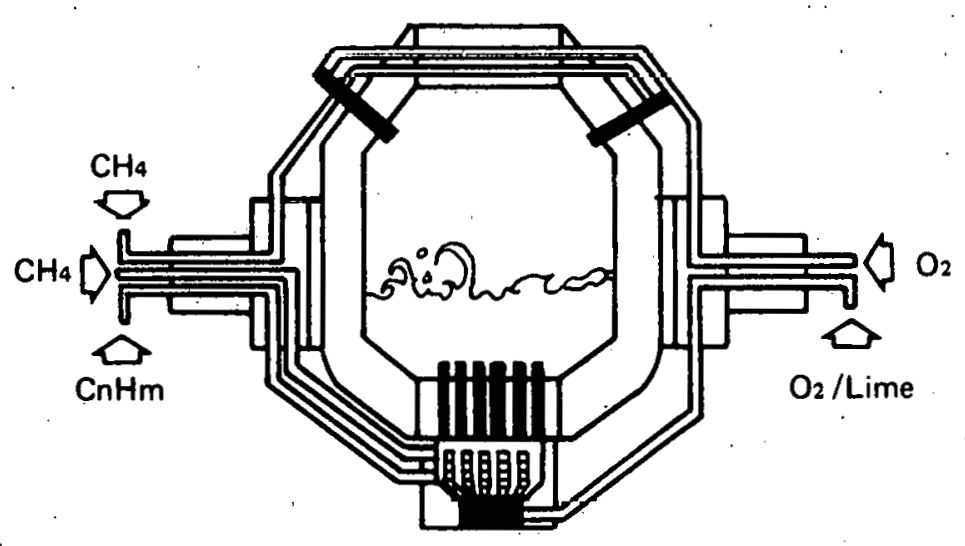

8unco: Scherriop, 1978.

FIGURE II-12 SCHEMATIC DIAGRAM OF AN OBMS FURNACE 


\section{b. Potential for Energy Savings}

Energy savings result from scrap preheating in BOF steelmaking furnaces because less hot metal is required per ton of raw steel produced as the fraction of scrap in the charge is increased. Hence, less energy must be expended in blast furnaces per ton of raw steel.

The approach taken here to estimate the energy conservation potential was to consider two cases:

1. BOF scrap preheating with top-lance injection of natural gas; and

2. OBM-S scrap preheating with bottom-blown fuel oil.

For both cases, we assumed that the consumption of oxygen, flux material, refractories, and alloying agents would be identical to that of a typical BOF operation. For top-lance injection, we assumed a preheat efficiency of $50 \%$ and a scrap charge of $40 \%$, while for the OBM-S case, we assume a preheat efficiency of $70 \%$ and a scrap charge of $.45 \%$ (Schempp, 1979). We also assumed that the OBM-S process would result in a $1 \%$ improvement in iron yield.

The energy consumption for these two situations is given in Table II-7, along with the energy consumption in a typical BOF shop without preheating. It should be noted that the energy consumptions shown in. Table II-7 do not contain allowances for oxygen, flux materials, refractories, or allowing agents, since we assumed the consumption of these items would to be identical for these three cases.

Table II- 8 presents the energy savings associated with scrap preheating, taken from Table II-7. Energy savings are presented in terms of Btu's per ton of raw steel; Btu's per incremental ton of scrap; quads per year, based on BOF production; and quads per year based on available scrap. In the latter two cases, we assumed, respectively that:

(1) All BOF operations currently in production in the United States would adopt scrap preheating and that total BOF raw steel production would be 83 million tons (AIME, 1979); and

(2) Only 10 million tons of scrap, the current level of U.S. scrap exports, would be available for use in BOF furnaces utilizing scrap preheating. As indicated, total energy savings range from 0.21 to 0.32 quads per year.

While these potential energy savings for scrap preheating are reasonable within the context of the assumptions made, it must be realized that the domestic integrated steel industry, as a whole, tends to limit its involvement with domestic scrap processes because of the volatility of the purchased scrap market. The steel industry has effectively utilized purchased scrap when supplies are available and the price low, but has only done this on a site-specific and time-dependent basis. To expect all BOF shops to convert to top-lance scrap preheating or to OBM-S systems, and to operate these furnaces at maximum scrap capacity on a full-time basis would be unrealistic. 
TABLE $\| 1.7$

ENERGY CONSUMPTION FOR TWO SCRAP PREHEATING OPTIONS ${ }^{\mathrm{a}}$

\begin{tabular}{|c|c|c|c|c|c|}
\hline Case & Charge & Units & $\begin{array}{l}\text { Units/Ton } \\
\text { Raw Steell }\end{array}$ & $10^{6}$ Btu/Unit & $\begin{array}{l}10^{6} \text { Btul. } \\
\text { Raw Steel }\end{array}$ \\
\hline $\begin{array}{l}\text { Base-BOF wi-hout } \\
\text { preheating }\end{array}$ & $\begin{array}{l}\text { Hot metal } \\
\text { Scrap }\end{array}$ & $\begin{array}{l}\text { tons } \\
\text { tons }\end{array}$ & $\begin{array}{l}.778^{d} \\
.314^{d}\end{array}$ & $\begin{array}{l}23.12^{\mathrm{d}} \\
0.5^{\mathrm{e}}\end{array}$ & $\begin{array}{r}17.99 \\
0.16 \\
\end{array}$ \\
\hline Total Energy Consumption & . & & & & 18.15 \\
\hline $\begin{array}{l}\text { BOF with top-lance } \\
\text { preheatirg }\end{array}$ & $\begin{array}{l}\text { Hot metal } \\
\text { Scrap } \\
\text { Natural gas. }\end{array}$ & $\begin{array}{l}\text { tons } \\
\text { tons } \\
10^{3} \text { cuft }\end{array}$ & $\begin{array}{l}.650 \\
.434 \\
.41\end{array}$ & $\begin{array}{c}23.12^{\mathrm{d}} \\
0.5^{\mathrm{e}} \\
1.0^{\mathrm{d}}\end{array}$ & $\begin{array}{r}15.03 \\
.22 \\
.41 \\
\end{array}$ \\
\hline Total Energy Consumption & & & & & 15.66 \\
\hline OBM-S ${ }^{c}$ & $\begin{array}{l}\text { Hot metal } \\
\text { Scrap } \\
\text { Oil }\end{array}$ & $\begin{array}{l}\text { tons } \\
\text { tons } \\
\text { gal }\end{array}$ & $\begin{array}{l}.588 \\
.481 \\
3.28\end{array}$ & $\begin{array}{l}23.12^{d} \\
0.5^{\mathrm{e}} \\
0.15^{\mathrm{d}}\end{array}$ & $\begin{array}{r}13.59 \\
.24 \\
.49\end{array}$ \\
\hline
\end{tabular}

FOOTNOTES:

a. Consumption of fluxes, oxygen, refractories, and alloying agents assumed constant for all cases.

b. Assumes $40 \%$ scrap charge and $50 \%$ preheating efliciency.

c. Assumes $45 \%$ scrap charge, $70 \%$ preheating efficiency, and $1 \%$ improvement in ircn recovery.

d. Battelle Columbus Laboratories, "Potential for Eriergy Conservation in the Steel Industry," Contract No. CO-04-51874-00, May 30, 1975.

e. Kusik, C.L., and C.B. Kenahan, "Energv Use Patterns for Metal Recyding," U.S. Burezu of Mines Information Circular, IC8781, 1978. 
TABLE II-8

POTENTIAL ENERGY SAVINGS ASSOCIATED WITH BOF SCRAP PREHEATING

\begin{tabular}{|c|c|c|}
\hline Energy Savings & $\begin{array}{l}\text { BOF with Top } \\
\text { Lance Preheating }\end{array}$ & OBM:S \\
\hline $10^{6} \mathrm{Btu} /$ ton raw steel & 2.48 & 3.81 \\
\hline $10^{6}$ Btu/incremental ton scrap & 20.67 & 22.81 \\
\hline $\begin{array}{l}\text { Quads/year based on production } \\
\text { of BOF raw steel }\left.\right|^{\mathrm{a}}\end{array}$ & 0.21 & 0.32 \\
\hline $\begin{array}{l}\text { Quads/year based on "available" } \\
\text { scrapb }\end{array}$ & 0.21 & 0.23 \\
\hline
\end{tabular}

a. Assumes all BOF operations adopt scrap preheating and that total BOF production is 83 million tons of raw steel.

b. Assumes that only 10 million tons of scrap (the current level of U.S. scrap exports) are available for use in BOF scrap preheating operations.

Therefore, the actual energy savings that could realistically be obtained with scrap preheating would range from 0.05 to 0.15 quad per year, or $0.60 \times 10^{6}$ to $1.81 \times 10^{6} \mathrm{Btu}$ 's per ton of raw steel, based on the production of BOF raw steel in 1979 (83 million tons).

\section{c. Present Status of Development}

BOF scrap preheating using top lances as oxy-fuel burners has been utilized for many years by the domestic steel industry when supplies of scrap are high and scrap prices low. Installations, such as the Alan Wood BOF shop, have used this technology on a day-to-day basis. While tests in other plants have tended to be short term, or small scale, the technology must be considered fully developed and well known throughout the steelmaking industry.

On the other hand, the OBM-S process has only recently been introduced to American steelmakers. This process, however, has been demonstrated in 235- and 250 ton vessels in West Germany, where it was developed. At present, there is only one plant that has implemented this process, viz., National Steel's Granite City operation. National is proceeding with the modification of the plant's two 235-ton top-blown basic oxygen furnaces to make them jointly top and bottom blown. This process, known as the KMS (Klochner Maxhuette Scrap) system, is similar to the OBM-S process, except that bottom-blown oxyacetylene is used for scrap preheating. Because of its proprietary nature, National Steel will not divulge more specific information. However, conversations with National Steel's research managers revealed that the KMS will allow scrap charges of $45 \%$ to be used, increase iron recovery by $1-1.5 \%$, and produce a cleaner off-gas. Scrap utilization can be further increased by injecting carbon through the bottom tuyeres. 
The completion of Granite City's furnace conversion. project is scheduled for the end of 1980. National Steel had also planned to install the KMS system in its Great Lakes division, but is presently holding up on the project because of a lack of capital.

\section{d. $R \& D$ Needs and Development Cost}

Top-lance preheating in a BOF converter can be considered a fully developed and demonstrated process technology. Potential improvements to this process would be operational in nature and include such items as decreasing preheat times and refractory.wear. The OBM-S process has been demonstrated in European steelmaking plants (Boudin et al., 1979; Schempp, 1979) and is presently being installed in one U.S. operation. We understand that coke injection through bottom tuyeres to increase scrap capacity beyond $45 \%$ will also be tested. However, within the context of this study, these proccsscs arc being, or have been, demonstrated on a reasonable scale and with industry support; therefore, the rationale for Federal Government support should be carefully evaluated.

\section{e. Role of the Federal Government}

The domestic steel industry sees several advantages associated with the OBM-S process, from improved metallurgy to scrap flexibility, and is carefully monitoring National Steel's progress in installing the KMS system. Should National Steel be successful, other companies will undoubtedly begin evaluating the possibility of installing OBM-S systems in their own plants.

\section{Computer Model of Electric Arc Furnace}

\section{a. Description}

Electric arc furnace production in the United States currently runs to about 34 million tons of raw steel per year. An examination of announced capacity increases in steelmaking indicates that electric furnace capacity will increase by about 5 million tons. In addition, the rate of BOF to electric arc furnace production is about 1:1 for planned capacity additions. Since the BOF does not have the scrap-melting capacity of the open hearth, electric arc furnaces will take over part of the scrap melting function of the open hearths that presently remain and are expected to close over the next decade.

Electric furnaces consume a reported average of $480 \mathrm{kWh}$ per ton of raw steel; this translates into 0.17 quad for the 34 million tons produced in 1979.

The principal heat losses arise from the following:

- Air drafts into the furnace and, from there, into the pollution control system;

- Losses from the furnace shell to the environment;

- Cooling during charging; and

- Resistance losses in the electrical system. 
An optional design should therefore include:

- Fast and efficient melting, which would require a modern ultra highpower supply and possibly preheated scrap;

- Efficient heat transfer for fast melting and minimum shock to the refractories; and

- Fast charging procedures.

\section{b. Potential for Energy Savings}

The thermal efficiency of electric furnaces is of the order of $75 \%$ at present. A $5 \%$ improvement would represent $24 \mathrm{kWh}$ per ton $(0.25$ million Btu/ton), or 0.0085 quad in 1979. Such savings would be reflected in the amount of fuel used by power generating stations.

\section{c. Present Status of Development}

The Massachusetts Institute of Technology, supported by the Department of Energy, is directing a project involving the development of a mathematical model of electric arc furnace operations. The purpose of the investigation is to develop a quantitative understanding of both the fundamental principles underlying the operation of electric arc furnaces and the operational dynamics of melt shops. This project was started in 1977 . Work has been done in the following areas:

- Mathematical Modelling of the Plasma Arc - A mathematical model has been developed to calculate velocity fields and temperature profiles in single-phase DC arcs. A heat balance has been established and the rate of heat transfer to the anode has been related to various operating parameters.

- Systems Modelling of Electric Arc Furnace Shops

\section{d. $R \& D$ Needs and Developmental Costs}

In spite of numerous past investigations, no satisfactory theoretical account of heat transfer, fluid flow, and melting phenomena in the electric arc furnace has been produced. A better understanding of such phenomena could lead to improvements in thermal efficiency; perhaps $5 \%$ would be a reasonable goal over the coming decade. The steel industry would certainly be receptive to better operating ideas; implementation would then be a question of overall economics.

Further work with respect to electric arc furnace modelling would involve an examination of the interaction of the plasma jet (electric arc) on the molten metal on which it impinges. The goal of such modelling would be to extend the three-phase electric furnace plasma jet. The results of such modelling might be useful in understanding the plasma steelmaking process that has been proposed (ASEA-SKF).

\section{e. Role of the Federal Government}

This work is of a theoretical nature and, since it is unlikely that steel companies would mount significant reseurch effurt of a basic nature, continuation of this project 
should be supported by the DOE. Potentially, it could result in a more energy-efficient practice for all electric arc furnace operators, including those who could never afford that type of research. Thus, modest funding by the DOE may play a meaningful role in this potential energy-conserving project.

\section{Particle Melting}

Fragmented scrap and direct reduced iron (DRI) pellets could become increasingly important to the steel industry in future years. Both of these sources of ferrous values conserve metallurgical coke, since blast furnace operations are not necessary in their production. Both will serve primarily as electric furnace feedstock, although the possibility of limited use in BOF and open-hearth operations also exists. Because of the size and shape of these materials, it is feasible to continuously feed them into electric steelmaking furnaces and thereby improve productivity. In fact, the continuous feeding of D-R pellets has been practiced for several years in a number of installations.

However, Elliott (1978) suggested that the mechanisms involved in the melting of fragmented scrap and D-R particles are not well understood; hence, the data necessary for the design and operation of an optimal melting system for energy conservation (or for other purposes as well) are not available. Therefore, Elliott has proposed that an investigation be directed into the factors that determine the rates at which particles of D. $R$ materials and scrap are melted in steelmaking operations, and how it might be possible to accomplish melting with greater efficiency in the use of energy, both by improved melting operations and by the use of energy-conserving raw materials.

\section{a. Description}

The melting of D-R materials and scrap particles is a complicated process. Particles must be transported through an agitated slag layer to the slag-metal interface. During this time, the particles are heated by radiation from furnace walls and from the slag, and the heat conducted from slag and metal interfaces. The extent to which a frothy slag affects the heat transfer process is unknown, but it is generally accepted that good bubbling action decreases furnace wear, and so a frothy slag is usually encountered. The melting process for both $D \cdot R$ materials and scrap fragments should be similar, except that D-R materials engender gases which may or may not improve heat transfer. The effects of varying the degree of metallization of D-R particles (and thereby influencing the volumes and rates of gas evolution) on electrical energy consumption is not known. Although a particular D-R product may be "optimal" with respect to the reduction process from which it was produced, it may not be "optimal" with respect to the melting process.

The investigation proposed by Professor Elliott involves experimental measurements of various types of D-R materials and laboratory and computer modelling of the heating and melting particles in an electric arc melting system.

\section{b. Potential for Energy Savings}

Unlike most other energy-saving projects evaluated in this report, this particular project does not involve a new technology, but rather improved operating conditions. 
Furthermore, it is a theoretical investigation based on laboratory studies. While this project deals primarily with the use of DRI materials, the results may be applicable to the melting of scrap agglomerates and particles. This would include fragmented scrap, turnings and borings, and slag scrap fines. Although this study's potential for energy conservation is broad in scope, the data necessary for calculating energy savings cannot be well defined. Therefore, the approach taken here was to consider this project to be essentially an effort to improve operating procedures for electric furnace steelmaking. Based on experience with other investigations involving improved operating practices, such as the implementation of computer control, a potential energy savings of $5 \%$ of total energy input is reasonable to expect. This energy savings should include both a reduction of electrical energy and a savings in electrode use. If one assumes that $550 \mathrm{kWh}$ of electrical energy is required per ton of steel produced, and about $0.96 \times 10^{\circ}$ Btu per ton of energy is lost in electrode wear (Battelle, 1975), an improvement of 5\% would result in a savings of

$$
\begin{gathered}
0.05\left[550 \mathrm{kWh} / \text { ton } \times 10,500 \mathrm{Btu} / \mathrm{kWh}+0.96 \times 10^{\circ} \mathrm{Btu} / \text { ton }\right] \\
=0.34 \times 10^{\circ} \mathrm{Btu} / \text { ton. }
\end{gathered}
$$

Since about 34 million tons of raw steel were produced by electric furnace in 1979 (AISI, 1979), total energy savings per year would be about $1.14 \times 10^{19} \mathrm{Btu}$ 's per year. Importantly, since electric furnaces are expected to increase their share of raw steel production, this potential for energy savings should increase in the future. It should be noted that this calculated energy savings does not include credits for increased scrap utilization or for the use of direct reduced iron pellets.

\section{c. Present Status of Development}

The investigation of the factors involved in the melting of D-R materials and scrap particles is currently being conducted under the direction of Professor Elliott at the Massachusetts Institute of Technology. The status of the three-phase investigation (described in subsection (a) above) is as follows:

- Task 1 - MIT has conducted previous studies to determine the volume and composition of the gases evolved from commercially available D-R materials as they are heated (Elliott, Nauman, Sadmezhaad, 1978; Sadrnezhaad, 1979). Included are tests done on Midrex pellets, coarse ore, and HyL pellets. This work is presently being expanded to include FIOR and HIB briquettes and SL-RN product. Work is also proceeding on the important question of developing $D-R$ samples of consistent properties.

- Tusk 2 - Wuik on the physical modelling of heat transfer in a boiling slag using pellets made of pivalic acid in air agitated water (or glycerolwater) has been completed. These tests showed that heat transfer can be described by the following dimensionless relationship:

$$
\mathrm{Nu}=0.167(\mathrm{Ko})^{1 / 8}(\mathrm{Sc})^{1 / 8} \text {, }
$$

where $\mathrm{Nu}$ is the Nusselt number, Ko the Kolmogoroff number, and Sc the Schmidt number. It was also determined that; for clumps of particles, the heat transfer area of concern is the exposed area and not the 
sum of individual particle areas. No further work along these lines is planned.

- Task 3 - Work on developing a computer model of continuously feeding DRI and fragmented scrap to an electric furnace has not yet been started. It will be initiated toward the completion of Task 1 .

\section{d. R\&D Needs and Development Costs}

Based on conversations with Professor Elliott, we estimated that the additional budget required to complete the project would range from $\$ 50,000-\$ 100,000$. Within the next two years, full-scale testing would be necessary to demonstrate concept feasibility. We estimated that $\$ 200,000-400,000$ would be necessary for this work. Hence, we estimate the total additional development costs necessary to demonstrate improved particle melting techniques will range from $\$ 500,000-\$ 1,000,000$. This work would involve only the melting of D-R materials and scrap in electric furnaces. The application of improved melting techniques to other steelmaking furnaces would require additional expenses which cannot be estimated at this time.

\section{e. Role of the Federal Government}

In view of the theoretical nature of this work and of its broad consequences, it may be appropriate for the Federal Government to fund the initial studies, that is, the present work and any follow-on work that might be necessary to complete the computer modelling task. Additional Federal funds should be used to provide the incentives for the various steel companies to initiate full-scale testing. This might include publicizing laboratory findings and providing for measurement equipment and trained man-power for initial full-scale tests followed by disseminating results.

\section{STEELCASTING, REHEATING AND HEAT TREATING}

\section{Conventiürial Technology}

\section{a. Steelcasting}

The conventional-and original-method of casting steel, not only in the United States, but largely throughout the world, involves pouring molten steel (from the various steelmaking processes) into cast iron molds of various designs and dimensions: In this process, molten steel is poured into receiving ladles, which are transferred by crane to a line of ingot molds standing on small rail cars. The molten steel is discharged (teemed) from the bottom of the ladle through a control valve into the molds. After solidification, the filled ingot molds are usually transferred by rail to a stripping building where the molds are removed from the ingots. Ingots are then reheated in soaking pits to $2200^{\circ}-2400^{\circ} \mathrm{F}$ and rolled into slabs, blooms, and billets on primary breakdown mills.

In continuous casting, a newer technology, multen steel is directly converted to semi-finished forms, e.g., (slabs, blooms, and billets), thus eliminating the need for soaking pits and primary breakdown mills. The basic concept is to use an open-ended mold for casting product to the approximate dimensions of the final or intermediate 
product. Besides saving the energy associated with soaking pits and primary breakdown mills, continuous casting also results in a higher yield and improved labor productivity.

\section{b. Reheating}

Steel is reheated to make it plastic enough for economic reduction in size to the desired shape by rolling or forging. Ingots are reheated in soaking pits prior to being formed into slabs, billets, and blooms, and these shapes, in turn, are reheated prior to various hot rolling and working operations.

The heating furnaces used in the steel industry are of three principal types:

- Soaking pits for primary heating,

- Slab/bloom reheaters for intermediate heating, or reheating, and

- Billet reheaters for intermediate heating, or reheating.

Estimated capacities of U.S. steel industry soaking pits and reheating furnaces are given in Table II-9.

\section{TABLE $\| 1.9$}

\section{ESTIMATED CAPACITIES OF U.S. STEEL INDUSTRY SOAKING PITS AND REHEATING FURNACES (millions of tons)}

Type of Furnace

Ingot Soaking Pit

Cast Bloom and Billet Heating Furnaces

Siab Reheaters - Plate

Slab Reheaters - Strip

Bloom Reheaters

Billet Reheaters

Pipe Mill Reheaters

Tube Mill Reheaters

Forging Reheaters

Heavy Structural Mill Reheaters

Rail Mill Reheaters
Capacity

185

10.15

15

95

50

45

5

5

5

10

3

Source: Arthur D. Little, Inc.

A soaking pit is a heating furnace in which "as-cast" ingots are preheated to $2150^{\circ}-2450^{\circ} \mathrm{F}$ prior to hot rolling. The temperature of the soaking pit varies with the grade of steel, size of ingot, and rolling mill characteristics. Various designs of soaking pits are used, depending on the requirements of ingot shape, reheat temperature, furnace atmosphere, and the like. The United States has more than 2,500 soaking pits with an estimated totul reheat capacity of approximately 185 million tons. The capacity utilization factor for these units is about $60-70 \%$. 
Slab/bloom reheat furnaces are used to reheat slabs and blooms for further conversion into hot-rolled mill products. Their temperature is generally in the 2200 $2400^{\circ} \mathrm{F}$ range. Two principal types of slab/bloom reheating furnaces are used in the U.S. steel industry: the pusher type and the walking-beam type.

About $90 \%$ of all slab/bloom reheating furnaces are of the pusher type. In these furnaces, the inspected slab (which is usually at ambient temperature) is moved by a mechanical pusher through the furnace on longitudinal pipes or "skids" at a controlled rate. Normally this furnace has several combustion zones, each with separate temperature controllers and burners.

Walking-beam furnaces, a newer technology, were introduced to overcome some of the limitations and drawbacks of the pusher type. These furnaces have a set of stationary water-cooled skids as well as a set of movable skids. Slabs arc lifted by the movable skids, advanced a few feet toward the discharge end, and lowered back on the stationary skids. The movable skids then return to their starting point and a new cycle begins. Walking-beam furnaces provide a higher reheating capacity per unit hearth area and a more uniformly reheated slab than do pusher-type furnaces, but capital costs are higher and energy efficiencies are lower.

The billet reheating furnace is used to reheat steel billets to $2100-2300^{\circ} \mathrm{F}$ for rolling in a rod or bar mill. Practically all of these furnaces are of the pusher type.

\section{c. Heat Treating}

Heat treatment is a process of controlled heating and cooling of steel workpieces . such that desirable physical and/or mechanical properties are attained through changes in the steel's microstructure. Various heat-treatment methods are used in the steel industry, including annealing, normalizing, carburizing, and tempering. Of these, annealing uses the largest amount of energy in the U.S. steel industry because of the tonnages treated.

The principul purposes of annealing are to relieve stresses induced by cold or hot working and to soften the steel so as to improve its machinability or formability. It may involve only a subcritical heating to relieve stresses, or heating above the critical temperature (that temperature above which phase changes occur) with subsequent transformation to pearlite on cooling.

The simplcst annealing furnaces are the direct-fired batch type with manual control. The more elaborate installations, used for large production lines, are continuous-strip furnaces with automatic program control. Approximately $60 \%$ of all annealing furnaces are dircct-fired, hut in situations where furnace atmosphcre control is critical, muffle furnaces and radiant tube-fired furnaces are among the available choices. The most common types of annealing furnaces are: box, car-bottom, bell, and pit.

Normalizing involves reheating the steel above its critical temperature and air cooling. It has two primary purposes: (1) to refine the grain, and (2) to obtain a carbide-size distribution which will be more favorable for carbide solution on subsequent heat treatment than the "as-rolled" structure. 
In carburizing, a high-carbon surface layer is produced on low-carbon steel by a surface reaction with carbonaceous materials. On quenching, the high-carbon "case" becomes very hard, while the low-carbon cone remains comparatively soft. The result is a wear-resistant exterior combined with a tough interior.

Carburizing is most commonly carried out by packing steel in boxes with carbonaceous materials, sealing to exclude the atmosphere, and heating to about $1700^{\circ} \mathrm{F}$. This process is known as pack carburizing. Carburizing may also be performed by heating steel in direct contact with carburizing gases, in which case it is known as gas carburizing. Less commonly, liquid baths of carburizing salts are used.

\section{Hot Inspection of Steel}

\section{a. Description}

Steelmakers have to inspect and remove many surface defects from all intermediate shapes. The process to remove the surface defects, called conditioning, is especially important to slabs, since mills process slabs into sheet and plate steel where high surface quality is essential. Hot inspection permits both the identification and the spot removal of the defects and permits further processing of hot intermediate shapes, such as slabs, blooms, or billets, without cooling for inspection. This procedure precludes the conventional requirement for reheating the intermediate shape to hotrolling temperatures, thereby conserving the reheating energy.

\section{b. Potential for Energy Savings}

The potential energy saving that might accrue for hot inspection and spot scarfing arises from the elimination of the reheating step for rolling. Comparisons with conventional rolling indicate energy savings of 2.2 million Btu per ton of hot strip mill product. An additional 0.1 million Btu per ton is conserved at the soaking pits by careful management of charging and holding practices. The combined energy savings amount to 2.3 million Btu per ton of steel mill product over conventional (cold) inspection of slabs and subsequent reheating.

On the basis of the above estimates, the potential energy saving hot inspection in 1979 would have amounted to $294 \times 10^{12} \mathrm{Btu}$, or approximately 0.29 quad. Table II- 10 . shows the methodology used in deriving the energy saving that would accrue from the total adoption of the technology based on 1979 production figures.

TABLE \|-10

ENERGY SAVING FROM HOT INSPECTION AND CONDITIONING FOLLOWED BY DIRECT ROLLING

Hot Inspection

$\frac{\begin{array}{c}\text { Energy Saving } \\ \text { (Btu/ton) }\end{array}}{2.3 \times 10^{6}}$

$\frac{\begin{array}{c}\text { Total Raw Steel Production } \\ \text { (ton/year) }\end{array}}{128 \times 10^{6}}$

Total Energy Saved (Btu/year)

$294 \times 10^{12}$ 


\section{c. Present Status of Development}

In a joint program partially funded by the DOE's Office of Industrial Programs, the Honeywell Corporation and the U.S. Steel Corporation are in the initial stages of developing and testing a prototype system for hot inspection. In this program, the sensors and computer logic that will permit the detection of surface flaws on the hot steel shapes are being developed. If all the project goals are realized, the hot inspection prototype should be built and tested within the next three years. Until the prototype system is built and tested, however, we will not know whether the system has reached a point of development that will foster a wide adoption by the steel industry.

\section{d. $R \& D$ Needs and Costs}

We could not conduct an independent asscssment of the lechnology, since the detailed reports on the technology were not available to us. The critical tests of the adequacy of a hot-inspection system will occur during a forthcoming testing phase. The cutal cost of developing hot-inspection to the demonstration stage is estimated at about $\$ 7$ million with this program calling for funding support of $\$ 3.5$ million hy the the U.S. Department of Energy.

\section{e. Role of the Federal Government}

The Federal Government should consider continuing its support of the project if it fits within its prevailing energy and budgetary guidelines. The program is in the high-risk development phase where it might be discontinued without the incentives of Federal cost-sharing.

\section{Slot Forge Furnace}

\section{a. Description}

The forging industry uoco olot furnaces to lieal welul "sluck" (rods, bars, billets, and the like) of various sizes in preparation for forging into various shapes, such as automotive parts, hand tools, and the like. Basically, the slot forge furnace is a 10-foot wide insulated box fired by one or more oil or gas burners. Along the hnttom of one side is a slot (4-6 inches high) through which the material to be heated is handled. This opening usually has no door or enclosures. These furnaces typically operate at a very low efficiency, largely because the hot gas from the furnace interior exists at a high temperature. Other large sources of heat loss include radiation from the slot and, as in other furnaces, conduction through the walls, roof, and bottom. The schedule of the furnace operation (starts, slowdiowns, and shutdowns) also affecto furnace efficiency. In a typical slot forge furnace, only 5 to $15 \%$ of the heat content of the fuel is consumed in heating the stock. Energy efficiencies of 5 to $10 \%$ are common.

Under contract with ODE, Hague International, Inc., of South Portland, Maine, develuped and demonstrated a new high-efficiency slot forge furnace. The principal features of this furnace include:

- A high-temperature ceramic recuperator; 
- A recirculating burner; and

- An improved furnace design (slot closure doors, insulation, sensors, and a cold frame).

The greatest improvement results from reducing the stack gas temperatures by using a high-temperature ceramic recuperator which consists of multiple ceramic (SiC) tubes, ball and socket-jointed and spring-loaded. All components are manufactured by Hague International.

The recuperator is a simple cross-flow type, with design effectiveness of about $55 \%$. A new design version with two-stage cross-counter flows is being developed, and its effectiveness has been measured as high as $67 \%$. The recuperator is designed to be able to preheat combustion air to $1500-1800^{\circ} \mathrm{F}$; to date, however, a maximum preheat temperature of $1350^{\circ} \mathrm{F}$ has been achieved, and in a more typical field operation, air is preheated to the $1000-1200^{\circ} \mathrm{F}$ range.

The recirculating burner is of the transjet type, designed to recirculate a unit mass ratio of furnace gases to combustion air. Improved furnace design included a roof-fired furnace designed for $250^{\circ} \mathrm{F}$ external wall temperatures with $2500^{\circ} \mathrm{F}$ furnace temperature. The Hague furnace also incorporates an 8-inch high slot with an enclosure or door. Use of a coal/oil slurry was also tested.

\section{b. Potential for Energy Savings}

According to Hague International, the mean specific heating rates of steel processed in its slot forge furnaces could be as low as 750 Btu's per pound. This is significantly lower than the industry practice of 2500 to 3500 Btu's per pound of steel processed ( 5 to 7 million Btu's per ton). However, since most original test work on the Hague furnace was done under controlled and optimum operating conditions with a relatively well trained staff, the results are probably optimistic for actual plant operating conditions. We expect that, under plant operating conditions, the slot forge furnace might achieve 800 to 1200 Btu's per pound of steel processed (1.6-2.4 million Rtu's per ton), depending on the throughput, operator training, maintenance, and other factors.

If all of the slot forge furnaces in the United States were to be replaced by Hague International's fuel-efficient furnaces, a projected sum of about $0.01 \mathrm{quad} / \mathrm{yr}$ of oil or natural gas energy might be saved. Most of the fuel $(\sim 80 \%)$ used - and thus to be saved - in the existing slot forge furnaces is natural gas.

\section{c. Present Status of Development}

The Hague International fuel-efficient slot forge furnace is fully developed and is presently being commercialized. According to Hague International, 12 systems, including 6 retrofit systems, have already been installed. However, as is the case with any new equipment development, design modifications can be expected to improve furnace performance. 


\section{d. $R \& D$ Needs and Development Costs}

There are only minor, if any, R\&D needs and development costs that remain, except for the commercialization and monitoring phase of this project. The monitoring phase is extremely important and should preferably be done independently by individuals not within Hague International. A well organized monitoring phase could cost as much as $\$ 200,000$ and is an important phase of the total commercialization program. In the monitoring phase, the performance of the equipment and drawbacks, if any, should be reported and commercialization strategies recommended.

\section{e. Role of the Federal Government}

Hague International's slot forge furnace has proved to be energy-efficient and already a number of units have been sold. The substantial saving justifies consideration of a number of actions or roles the Federal Government could play tu promote commercialization of this system. These should include:

- Implementation of an education program (through seminars, literature, etc.) for suppliers and potential users to learn from each other the pro's and con's of the system. Various components of energy-efficient furnaces (e.g., the ceramic recuperator recirculating burner, etc.), are also made by suppliers other than Hague International. They should also be a purt of the total program.

- Provision of financial incentives, such as federal tax credits, loan guarantees, and the like, to promote faster commercialization.

\section{Nitrogen-Based Carburizing}

\section{a. Descripliun}

Carburizing is a high-temperature process in which a carbonaceous material imparts a high-carbon surface layer or "case". to low-carbon steel. In pack carburizing. one packs the steel in a bed of solid carboneous material, such as coke, and heats the materials in the absence of air to $1700 \mathrm{~F}$. In gas carburizing, which includes nitrogenbased carburizing one heats the steel in direct contact with a reducing atmosphere of carburizing gas containing active gases, such as methane or carbon monoxide. One may represent the reactions as follows:

$$
\begin{aligned}
\mathrm{CH}_{4}+3 \mathrm{Fe} & \rightarrow \mathrm{Fe}_{3} \mathrm{C}+2 \mathrm{H}_{2} \uparrow \\
2 \mathrm{CO}+3 \mathrm{Fe} & \rightarrow \mathrm{Fe}_{3} \mathrm{C}+\mathrm{CO}_{2} \uparrow
\end{aligned}
$$

The principal advantages of gas carburizing over pack carburizing center on quicker processing of the sleel and closer tolerances on the case depth. The principal disadvantage of gas carburizing is the typical practice of using either natural gas or oil as feed material to generate the atmosphere. The steel manufacturers presently process most of their case-hardened steel by some form of gas carburizing.

The object of the development is to reduce the amount of natural gas or oil needed to generate the carburizing atmosphere. The development involves the use of nitrogen produced from an air-separation plant with the additions of other gases active 
in the carburizing process such as methane, methanol (it decomposes on contact with the steel to produce carbon monoxide and hydrogen), and carbon dioxide. The idea is that less natural gas or oil would be consumed generating the atmosphere in this fashion. An alternate method of reducing the gas and oil needed would be to use a coalfired burner to generate the feedstock for an endothermic gas.

\section{b. Potential for Energy Savings}

The Air Products Corporation has made several measurements of potential energy saving, based on both the energy needed to produce the atmosphere and changes in the feed needed to keep the furnace at temperature. The highest energy saving measured for a carburizing atmosphere was $17 \%$, reported in the firm's Sixth Quarterly Report. It was effected if the processor took advantage of a process offering a shorter treating time. A preliminary estimate of the effect of a $17 \%$ saving would be 10.2 trillion Btu's per year from conversion of endothermic atmospheres to nitrogenbased carburizing atmospheres. Table II-11 lists the assumptions used in deriving the savings.

\section{c. Present Status of Development}

As of April 1980, about 20 plants employed a nitrogen-methanol system to gascarburize steel products. Systems have been developed by the Linde Division of Union Carbide and Air Products Corp. In earlier visits, INEL/EG\&G personnel who inspected several of the heat treaters using the nitrogen-methanol system found that the users were highly pleased with their systems. The commercial viability of the process seems well advanced.

\section{d. $R \& D$ Needs and Development Costs}

Since the process has been commercially applied by the Linde Division, the project has passed the commercial demonstration stage. The estimated costs for all companies to test and prove this process for commercialization has been set at $\$ 1$ million.

\section{e. Role of the Federal Government}

The Federal Government should review its involvement in the program because of the present high commercial viability of this process.

\section{Fluid Bed Heat Treating}

\section{a. Description}

If a reservoir containing finely divided, inert particles is constructed so that a gas (or liquid) can be distributed and passed up through the bed of particles, a fluidized state in which the individual particles become microscopically separated from each other by the rising gas stream can be achieved. The fluidized bed behaves remarkably like a low-viscosity fluid, exhibiting characteristics which are generally attributed to a liquid state. 
TABLE $\mid 1-11$

\section{ENERGY SAVING FROM CARBURIZING ALL HEAT-TREATABLE ALLOY STEELS}

For 1978

All Alloy Steel Produced

Non Treatable Alloy Steels ${ }^{\dagger}$

- High-silicon Steels

- High-strength Steels

- Miscellaneous Steels

Total Non-Heatable

Heat-treatable Alloy Steel by Difference
Short Tons

Short Tons

$18,070,315^{*}$

$1,171,803^{*}$

$6,446,889^{*}$

$910,702^{*}$

Therefore, $\mathbf{5 2 . 8 \%}$ of all alloy steels are heat-lieatable

Total Alloy Steel Shipments

Total Heat-treatable Alloy Steel

(52.8\% of the Total)
$10,556,740$ * *

$5,574,000$

At an energy consumption of 10.8 million Btu's per Ton of Steel ${ }^{* * *}$ for the atmosphere and heating of the furnace, the maximum potential saving would be:

Saving $=(5,574,000$ tons $)\left(10.8 \times 10^{6}\right.$ Btu/ton $)(0.17)=10.2$ Trillion Btu's

"Metal Statistics 1979, Fairchild Publications, A Division of Capital Cities Media Inc., New York, N.Y., 1979, page 196.

* *Ibid., page 208.

* * Air Products Corporation data for a continuous-belt furnace, reported in Sixth Quarterly Report.

${ }^{\dagger}$ As designated by Air Products

Because of the excellent contacting characteristics between the solid particles and the liquid or gaseous phase, the fluidized bed has found numerous industrial applications in areas involving heterogeneous heat transfer, mass transfer, and chem ical reactions. One of the main users of this technique is the oil industry, where fluidized beds serve as reactors for production of high octane gasoline, thermal cracking of petroleum feedstocks, catalytic cracking of heavy hydrocarbons to lower molecular weight compounds, and carbonization and gasification of oil shale, coal, and coke. Physical operations performed in fluidized beds include drying of granular materials and powders, mixing of powders, quenching hot gases, and coating plastic materials on metal surfaces. 
Heat treatment in fluidized beds was originally patented in 1950: However, in the earlier furnaces, it was only possible to heat the beds electrically, making their use for metal processing at temperatures above $1300^{\circ} \mathrm{F}$. difficult and inefficient. The technique was therefore not widely adopted in industry. Recently though, with the advent of fuel-fired fluidized beds (in which a gas/air mixture is used both as a heating and fluidization medium), temperatures up to $2200^{\circ} \mathrm{F}$ are attainable in an effective and efficient manner. As a result, fluidized bed furnaces are available to perform standard heat treating operations, such as:

- Tempering,

- Annealing,

- Case hardening (carburizing),

- Carbonitriding,

- Patenting, and

- Recrystallization.

There are currently two types of fuel-fired fluidized beds: (1) internally fired beds that operate at high temperatures $\left(1400-2200^{\circ} \mathrm{F}\right)$ and $(2)$ externally fired beds that function at lower temperatures.

An example of an internally fired bed is shown in Figure II-13. Gas and air are mixed together in near stoichiometric proportions and passed through a porous ceramic distribution plate over which the particles are fluidized in the gas stream. The bed is held in a metallic or refractory container and is ignited by initially lighting the combustion mixture at the top. The flame-front gradually moves down the depth of the bed until it stabilizes above the ceramic plate. The combustion then takes place spontaneously within about 1 :inch of the plate surface. Metal components to be heated are immersed into the fluidized bath of particles as if it were a liquid.

Typical operating fluid velocities lie in the range of 0.5 to 3.0 feet per second with particles ranging from 300 to 800 microns in diameter. These parameters are usually chosen more to achieve stable fluidizing conditions than maximum heat-transfer conditions. At higher temperatures, however, a radiation effect minimizes the effects of particle diameter and fluid velocity on the heat transfer coefficient. Normal operating temperatures for internally fired fluidized beds lie in the range of 1400 to $2200^{\circ} \mathrm{F}$.

Because it is difficult to stabilize internally fired beds at temperatures below $1400^{\circ} \mathrm{F}$, externally fired beds must be used. In one type of externally fired fluidized bed (shown in Figure II-14) an excess air burner fires into a plenum chamber over which a fluidized bed is supported on a porous metallic distributor plate. The temperature of the bed is controlled by varying the gas supply to the burner at a constant air input. The bed is fluidized by the products of combustion from the plenum chamber. At the lower temperatures employed in externally fired beds, typically $450^{\circ}$ to $1400^{\circ} \mathrm{F}$, stable combustion conditions and radiation are not considerations. Particles within the bed are sized to achieve the maximum heat transfer coefficient consistent with good fluidization characteristics. 


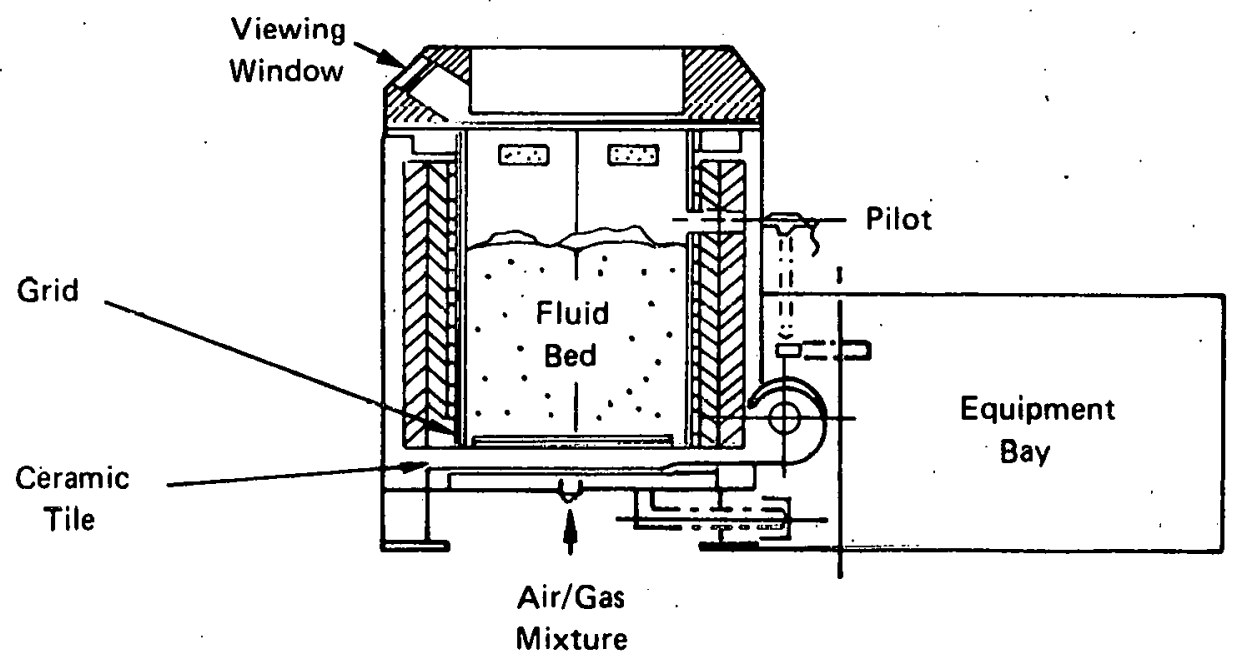

Source: Fennell, A.G., and Virr, M.J., 1978.

FIGURE II-13 SCHEMATIC DIAGRAM OF AN INTERNALLY FIRED FLUIDIZED BED FURNACE 


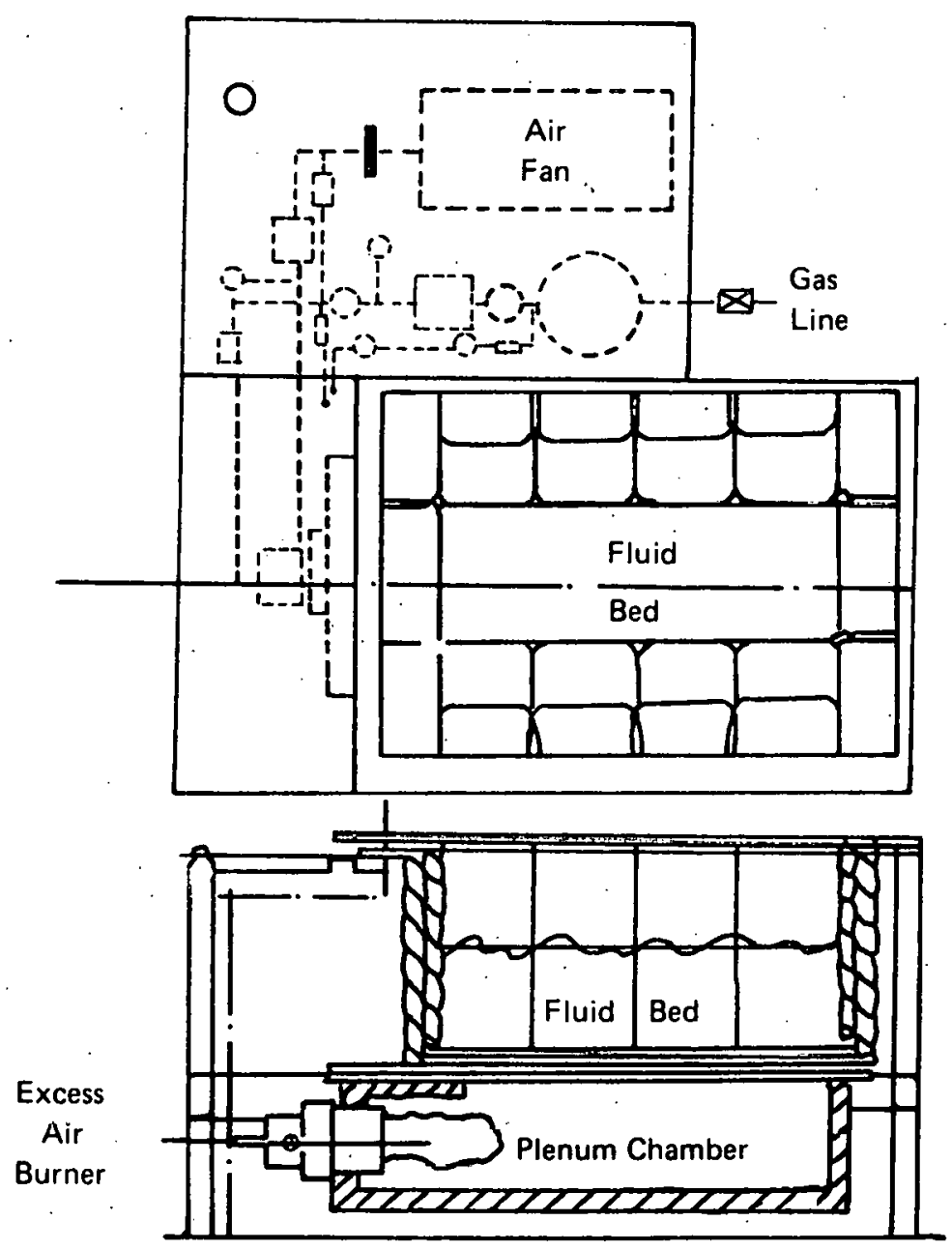

Source: Fennell, A.G. and M.J. Virr, 1978.

FIGURE II-14 SCHEMATIC DIAGRAM OF AN EXTERNALLY FIRED FLUIDIZED BED FURNACE 
Fluidized beds can also be heated electrically by suitably sheathed internal resistance elements which radiate heat to a metal container and thereby preheat incoming gas. The major disadvantages of electrically heated beds are their slow heating rate from cold conditions (typically $4-5$ hours to $1500^{\circ} \mathrm{F}$ ) and a slow recovery rate. Since the heat source is remote from the particles, a drop in heat-transfer efficiency results from heat having to pass through the interphases.

\section{b. Potential for Energy Savings}

Several investigators have reported that fluid bed heat treating can result in energy savings of more than $50 \%$ when compared with conventional heat treatment furnaces (Reynoldson, 1978; Fennell et al., 1978). These savings are generally the result of:

(1) Shorter processing times (which decrease furnace heat losses per ton of product), and

(2) The ability to shut off a fluid bed furnace when it is not in use due to its rapid heat-up characteristics.

Both of these benefits derive from the 5-to 10-fold increase in heat-transfer coefficients for fluid beds over conventional forced-air circulation furnaces.

Although the above energy saving per ton of product is fairly well documented, because of the amorphous nature of the heat treating industry, it is difficult to assess the impact of such savings on a national basis. Based on AISI statistics for finished steel, it has been estimated here that about 40 million tons of steel were heat-treated in 1979. Since the bulk of this steel was heat-treated in a neutral atmosphere (annealed, tempered, etc.), it is conservatively estimated that 1.3 million Btu's per ton of product are required for heat treating (Arthur D. Little, Inc., 1978). Hence, total energy requirements for heat treating are estimated at $4 \times 10^{13}$ to $1.2 \times 10^{14} \mathrm{Btu}$ 's for 1979 . On the assumption that fluid bed technology could be applied in $50 \%$ of all heat-treating farilities, and that a $50 \%$ reduction in onorgy conoumption would result, the total energy saving potential of fluid bed heat treating is estimated at $1 \times 10^{18}$ to $3 \times 10^{13} \mathrm{Btu}$ 's per year. This estimated energy saving does not include the application of fluidized beds to other heating practices, such as scrap preheating or steel reheating.

\section{c. Present Status of Development}

Fluidized bed technology for heat-treating ferrous products is fully developed and commercially available. What remains to be done is to convince practicing heat treaters that the tcchnology can result in a significant energy saving, while at the same time competing eoonomically with conventional furnaces.

At present, the main drawback to fluidized bed technology appears to be capital costs. Although these costs are somewhat lower than comparable salt baths (when required pollution control equipment is considered), they are higher than forced-air circulation furnaces. Furthermore, the impact on the heat-treating industry of rapidly replacing present operating furnaces with fluidized beds would be tremendous. Therefore, it appears that this technology will have to be phased in during the normal, albeit slow, course of capital replacement and improvement programs. 
To reduce the capital costs associated with fluid bed furnaces, DOE is currently investigating the feasibility of converting a typical conventional heat-treating furnace into a fluidized bed. This study, undertaken by Procedyne Corp., can potentially result in a conversion kit which could be made available to heat-treating shops and allow them to adopt fluid bed technology at reduced capital costs. Conversations with Procedyne indicate that an integral quench furnace has been successfully converted, and that field studies to document furnace performance will be performed in the near future.

\section{d. $R \& D$ Costs and Development Needs}

Since fluidized bed technology is commercially developed, R\&D needs are min. imal and, in general, tend to be associated with peripheral operations, such as materials handling. The application of fluidized bed technology to such heating operations as scrap preheating or steel preheating deserves further investigation. It is estimated that $\$ 200,000$ to $\$ 500,000$ may be required to investigate new applications for fluid beds and in determining optimum operating practices.

\section{e. Role of Federal Government}

Within the context of fluid bed technology, the role of the Federal Government is seen as one of monitoring and documenting the energy saving in operating plants and in publishing its findings. It may also be appropriate for the Federal Government to undertake basic studies into the applicability of fluidized beds into such areas as scrap preheating.

\section{E. OTHER ENERGY CONSERVATION OPPORTUNITIES}

\section{Iron and Steelmaking Dusts and Sludges}

\section{a. Description}

Flue dusts, mill scale, and other in-plant fines are generated in significant quantities at various stages of the iron and steelmaking sequence. In addition to iron, these materials contain such valuable constituents as carbon, zinc, and lead. Table II12 summarizes our estimates of the quantities and origins of emission of these materials in the United States, based on 1978 figures.

Examination of Table II-12 shows that about 19 million tons of flue dusts and mill scale are generated by the iron and steelmaking industry. Traditionally, the ironmaking flue dusts have been recycled to sinter strands, with both the iron and coke breeze values contained in the flue dust thereby being utilized. Mill scale has been recycled both to the sinter strand as well as the blast furnaces. As indicated in Table II-12, mill scale typically contains about $66-67 \%$ iron and predominantly consists of iron oxide.

Steelmaking flue dusts traditionally have not been recycled in the steel industry because of the large amount of zinc they contain. In the past few years, changes have started to occur in the iron and steel industry, with the resulting implication reflecting 


\section{TABLE $\|-12$}

\section{ORIGIN AND QUANTITY OF RECOVERABLE MATERIALS}

FROM FLUE DUSTS AND MILL SCALE IN THE

U.S. IRON AND STEEL INDUSTRY (1978)

Process Unit

\section{Iron Making}

Blast Furnace

\section{Strel Making}

Open Hearth

Basic Oxygen Furnace

Electric Arc Furnace

2

\section{Subtotal}

\section{Steel Fabrication, Finishing} Ingot Preparat:on,

Rolling Mills

TOTAL

\section{Nature and Comfosition}

of Effluen:

Flue Dust: $\mathrm{Fe} 41 \%, \mathrm{C} 33 \%$

Flue Dust: $\mathrm{Fe} 39 \%$, Zn 5-9\%

Flue Dust: Fe 46.6\%, C 1.85\%,

$$
\text { Zn 3-6.3\% }
$$

Flue Dust: $\mathrm{Fe} \mathrm{32 \% ,C} 1.85 \%$,

$$
\text { Zn 16.24.8\%, }
$$

$\mathrm{Pb} 2.5 \%$

Scarting, Mill Scale: Fe 66:4\%

$213.4 \mathrm{lb} / \mathrm{ton}$

raw steel
Quantity of Recoverable Materials (Million tons)
Amount of

Effluent

$44 \mathrm{lb} /$ ton

$22.5 \mathrm{lb} /$ ton

$47.5 \mathrm{lb} /$ tor

$24 \mathrm{lb} /$ ton
0.387

0.240

1.983

2.610

14.621

19.160 
upon the ability of steelmakers to recycle these materials. Because a larger and larger proportion of the iron making units fed to a blast furnace consist of pellets rather than sinter, there has been a decrease in the use of sinter strands in the United States. In addition, a large number of sintering facilities are relatively old and have large pollution control problems, with the result that many sinter strands are being forced to close because of pressures from air quality proponents. As a result, it is becoming more difficult to recycle blast furnace flue dusts and mill scale to on-site sinter strands at steel facilities.

Finally, many of the steel mills are relatively old and, as cities have expanded around the mills, available space around the mills has often become limited. As a result, many such mills are beginning to encounter difficulties in disposing of steel mill waste materials by land filling. This is especially true of the blast furnace flue dust and the steelmaking flue dust which account for more than 4.5 million tons of material annually. To a large extent, mill scale can still be recycled since some of it can be introduced into blast furnaces.

If a waste product is recycled to the blast furnaces or steelmaking furnaces, it would have to meet certain chemical and physical requirements. For example, in the blast furnace, the zinc and lead content of the flue dust must be low. Furthermore, the product must have physical strength, while having adequate reducibility and softening characteristics. If the recycled product is introduced into the blast furnace, iron can be in the form of an oxide. However, if such a product is introduced into the steelmaking .furnaces, such as the electrical arc furnace or the basic oxygen furnace, the iron oxide would have to be reduced because such steelmaking furnaces have little capability for econonically carrying out the reduction reactions.

Several processes have been developed for recycling of flue dust outside the United States, depending upon whether there is a need to de-zinc the material or not. All of the commercialized processes are pyrometallurgical in nature. The hydrometallurgical processes have not been developed to the point where they have been commercialized, although several patents do exist. Table II-13 summarizes the main processes that have been developed for recycling. The predominant processes which have the capability to remove zinc have been developed abroad. These include the German Lurgi process and the Japanese developments by Kawasaki, Sumitomo, Ryoho, and Sotetsu.

The predominant non-dezincing processes (i.e., those that do not have the ability to remove zinc) include the Grancold, asphalt bonding development by Heurtey and Shell in France, the Ferrocarb process, the Aglomet process and the MTU process (also known as the Pelletech process). Typically, these non-dezincing processes; are not carried out in a reducing atmosphere and thus the final product is an oxide which is only suitable for addition to blast furnace.

\section{b. Potential Energy Savings}

Most recycling processes provide an outlet for coke breeze. They also make use of the large amounts of carbon contained in blast furnace flue dusts. In this fashion, they combine natural resource recovery and fuel saving. 
TABLE II-13

\section{PROCESSES FOR RECYCLING FLUE DUSTS AND IN-PLANT FINES}

Process

Dezincing Processes

Kawasaki

Sumitomo

Sumitomo Dust Reduction (SDR)

Sumitomo Pre-reduction Method (SPM)

Ryülio Récycle

Sotetsu Metals (Waelz) Kiln Process

Lurgi Process (SL/RN)

Non-dezincing Processes

Grancold Process

Asphalt Bonding.

Ferrocarb Process

Aglomet Process

MTU Cold Bond Process (Michigan

Technical University)

Green Pelletizing Process

\section{Developer}

\author{
Kawasaki Steel Corporation, Kawasaki Heavy \\ Industries Ltd.; Japan \\ Sumitomo Metals, Sumitomo Heavy Industries, Jạpan \\ Sumitomo Metals and Kuboto Iron Works Company, \\ Japan
}

Mitșuḅișh! ạd Tôhó Zínc AEN, Japan

Sotetsu Metals, Japan

Lurgi GMBH, Germany

Granges A-B, Sweden

S.A. Heurtey/Shell Francaise, France

Reclasource, Subsidy, Berwind Corporation, U.S.A.

Aglomet Corporation

Pelletech Corporation, U.S.A.

Bethlehem Steel Corporation, U.S.A.

Pre-reduced pellets made from steel mill dusts, sludges, and the like, require about half the coke needed by oxide pellets in blast furnace smelting. These processes spare metallurgical coal, conserve natural resources, and save the energy used in mining, beneflciation, agglomeration, and transportation. Additional savings are associated with the zinc concentrate. A net energy balance for these recycling processes has to be developed.

It is not unreasonable to cxpcct the amount of waste materiuls recycled to the blast furnace to average $6 \%$ of the iron units contained in the burden. Such practice applied to pelletized prereduced materials would save about 0.037 quad in the form of coke (Arthur D. Little, 1978). 
Asphalt bonding in essence substitutes asphalt for metallurgical coke. The overall energy balance on a straight Btu basis is about even; the energy expended in briquette preparation is practically offset by the energy saved in recycling carbonbearing dusts.

Other cold bonding processes save energy in that they represent an on-site source of raw materials and thus eliminate energy use in mining, milling, and transportation.

\section{c. Present Status of Development}

All of the de-zincing processes have been demonstrated outside the United States. The Ferrocarb, Aglomet, and Pelletech processes were developed in the United States.

Steel mills have been reluctant to invest in such dust recycling facilities for a variety of reasons:

- It is unusual for a single plant to generate enough flue dust to supply a minimum, economic size flue-dust-recycling facility.

- Concerns have been voiced about a facility that would be jointly held by several steel companies, largely because it might trigger antitrust action.

- Because of limitations in internally generated capital funds and limitations in the ability to raise capital from outside sources, the steel industry would rather invest in steelmaking facilities which can increase the productivity, or otherwise might make them more competitive. As a result, there is a reluctance to invest in a flue-dust-recycling facility that is only a peripheral function to steelmaking activities. A 300,000 ton per year plant (the typical size of industrial kilns) would cost upwards of $\$ 20$ million.

The most advanced processes are the high-temperature de-zincing processes. They have been proven under Japanese conditions, but not under U.S. conditions. Economic calculations show them to be increasingly attractive, because of higher costs for disposal of flue dusts.

There is some technological risk, because flue dust processes are very difficult to operate properly, and because site-specific conditions may require major specific adaptations.

Because of present concerns relating to capital availability, the steel industry is not likely to make such an effort on its own. The lower temperature, cheaper processes have aroused enough interest to lead to industrial tests, but these tests have not been definitive to date.

\section{d. $R \& D$ Needs and Developmental Costs}

A Level 2 energy accounting study (including the energy of materials consumed) should be made to determine whether energy can be conserved by such recycling. Most 
of the available processes have been developed in response to environmental pressures and are not optimized with respect to energy use. There is a need to determine if existing processes can be optimized with respect to energy use.

Most of the de-zincing processes produce a zinc concentrate. Adequate technology has to be developed to handle such concentrates; i.e., to produce zinc metal or zinc oxide. Various hydrometallurgical and pyrometallurgical approaches have been suggested. One novel approach is the use of hydrocycloning of flue dusts-as zinc content of fines is richer with respect to zinc. Because of the variety of technologies involved, it is difficult to estimate developmental costs.

\section{e. Role of Federal Government}

As recycling might be a better way of addressing concerns about hazardous waste disposal, a Government-industry program aimed at develnning nptimum resyciline technology is desirable. Government agencies, such as the EPA and DOE, would probably be involved in such an effort.

\section{Hierarchical Computer Control}

\section{a. Description}

An all-encompassing hierarchical electronic data processing (EDP) system is shown in Figure II-15. Theoretically, it starts with subsystems under unit digital or analog control (Level 1) and winds up with a management information system (MIS) at the top (Level 4). The four-level distinction is not unique to the steel industry. With minor variations, it represents the general configuration adopted for complex industrial integrated EDP systems. A brief description of the four levels follows.

- Level 1 is the base of the pyramid. It consists of numerous autonomous regulators that control individual plant equipment (e.g., individual furnaces, casting machines, roll trains).

- Level 2 is the process control level which supplies optional set points to autonomous regulators.

- Level 3 coordinates the production level for each major plant subdivision (coking, blast furnace, steelmaking, rolling), executing the corresponding short-term preliminary production plant defined by Level 1.

- Level 4 is concerned with control planning in view of the order backlog and production data; it performs a number of administrative tasks that include short-term preliminary production plans for the operation as a whole.

The result is a fairly complex network of computers communicating with each other via a high-speed data highway or phone link. Each level controls the level immediately below it, and interferes as little as possible with any level above it except for feedback information. 
,

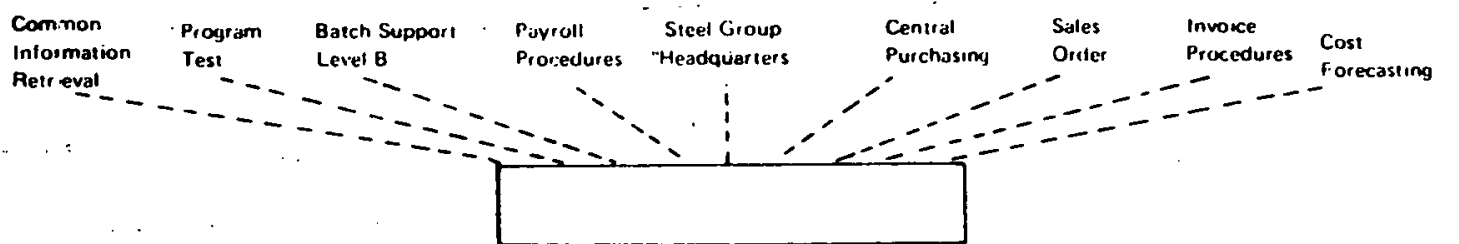

Level 1

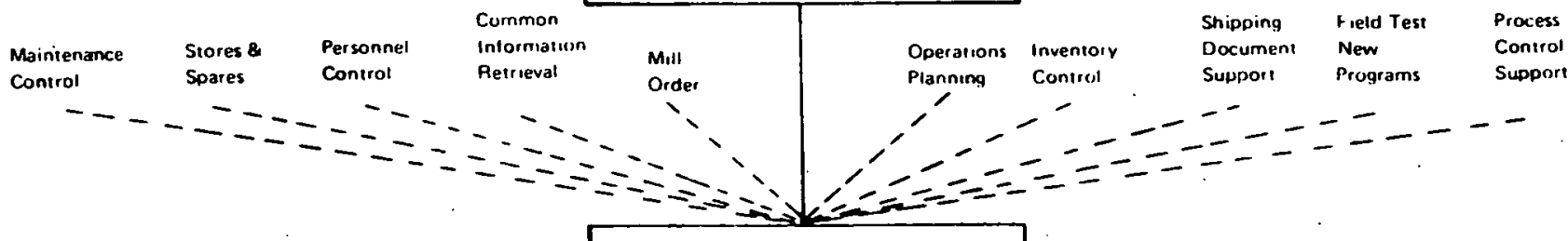

$\stackrel{\infty}{\infty}$

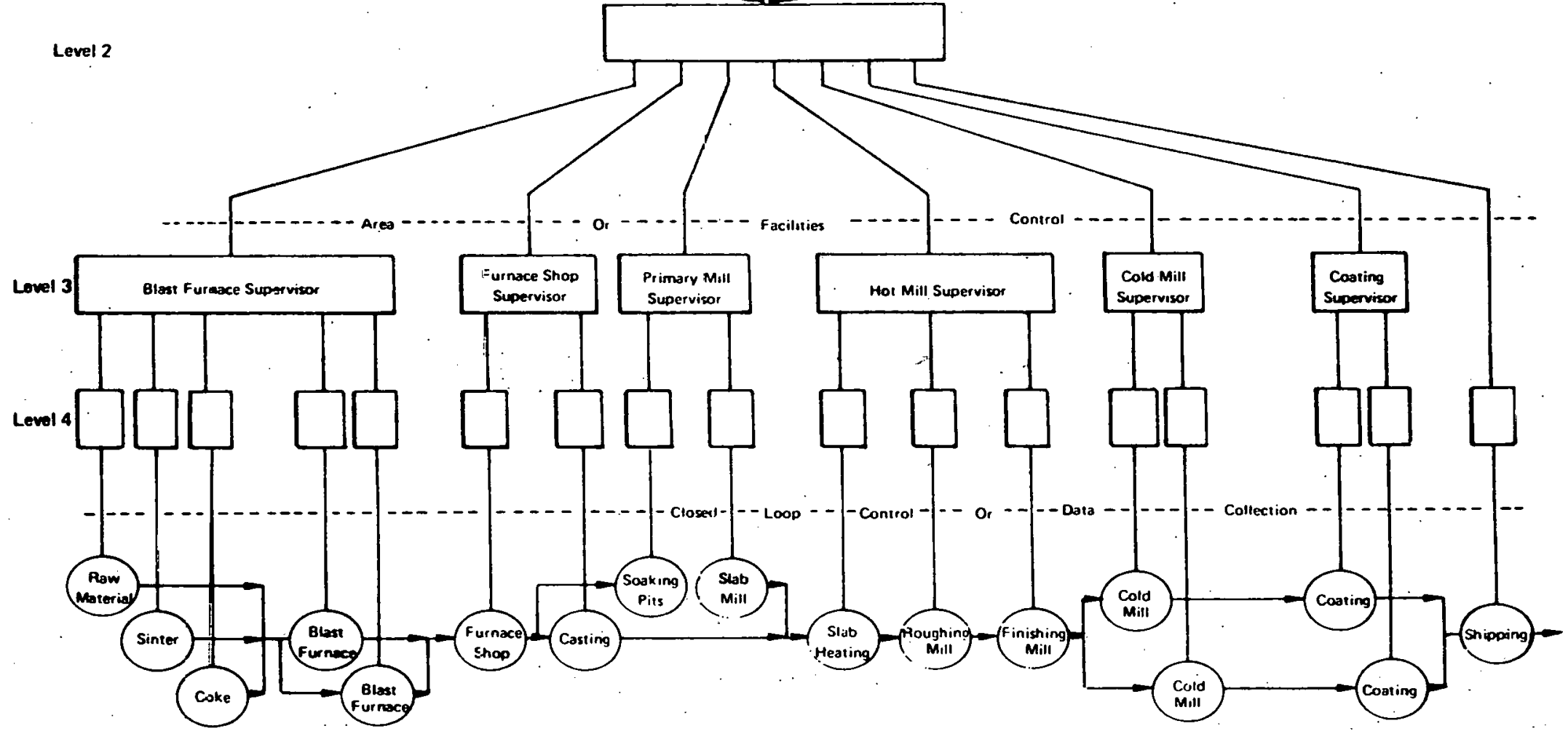

Source: Long, 1978. 


\section{b. Potential for Energy Saving}

Hierarchical EDP control would provide information to schedule materials and equipment throughout the steel plant. In addition, such a system would provide additional benefits in terms of improved yields and product quality and increased productivity of equipment and labor, with further energy conservation implied in improved productivity. Professor Theodore Williams of Purdue estimates a 5\% energy reduction from "control enforcement" and an additional 3-5\% from improved scheduling efficiency, or a saving of about 1.5-3.0 million Btu per ton of steel. It is possible that these savings are optimistic; however, no hard data are available. Major savings are likely to be realized primarily at the process level by better instrumentation, software development, and computer hardware.

\section{c. Present Status of Development}

The state of the art in integrated EDP systems is to be found in Japan, The large modern plants of Oita (Nippon Steel) and Kimitsu (Nippon Steel) are described as the most advanced achievement in the field. 'T'he Oita system (Figure II-16) is close to a complete "hierarchical" system. What is missing is essentially an optimizing algorithm that would use the data acquired by the system to supervise the entire operation. A number of links are still missing.

While no U.S. companies have systems integrated to the scale developed by the Japanese; the start of such systems is operational in the form of working linkages and data transfer between levels in six plants for four major U.S. companies (Long, 1978).

In 1973 the Purdue Laboratory for Applied Industrial Control established a project to develop the specification for an overall hierarchical computer control system for a large industrial manufacturing complex - a steel mill, for example. These specifications have been developed (Williams, 1980). In addition, major additional results were developed, as listed in Table II-14. The project was sponsored by the National Science Foundation and several U.S. and Canadian steel companies.

\section{d. $R \& D$ Needs and Developmental Costs}

The Purdue Laboratory for Applied Industrial Control has proposed a project to the Department of Energy to determine the potential energy benefits and costs of hierarchical computer control systems in an integrated steel plant. Such a project would quantify the energy saving to be derived from hierarchical computer control.

Substantial progress has been made in the needed technologies: sensnrs, thenretical models, computer hardware, and data processing. However. the environment (heat, dirt, corrosives, etc.) in this industry precludes the use of many commercially available sensors and analyzers. The need is then for development of suitable on-line sensors and anlyzers which can be profitably produced and are cost effective to purchase.

Levels 3 and 4 are still plagued by the following problems: 


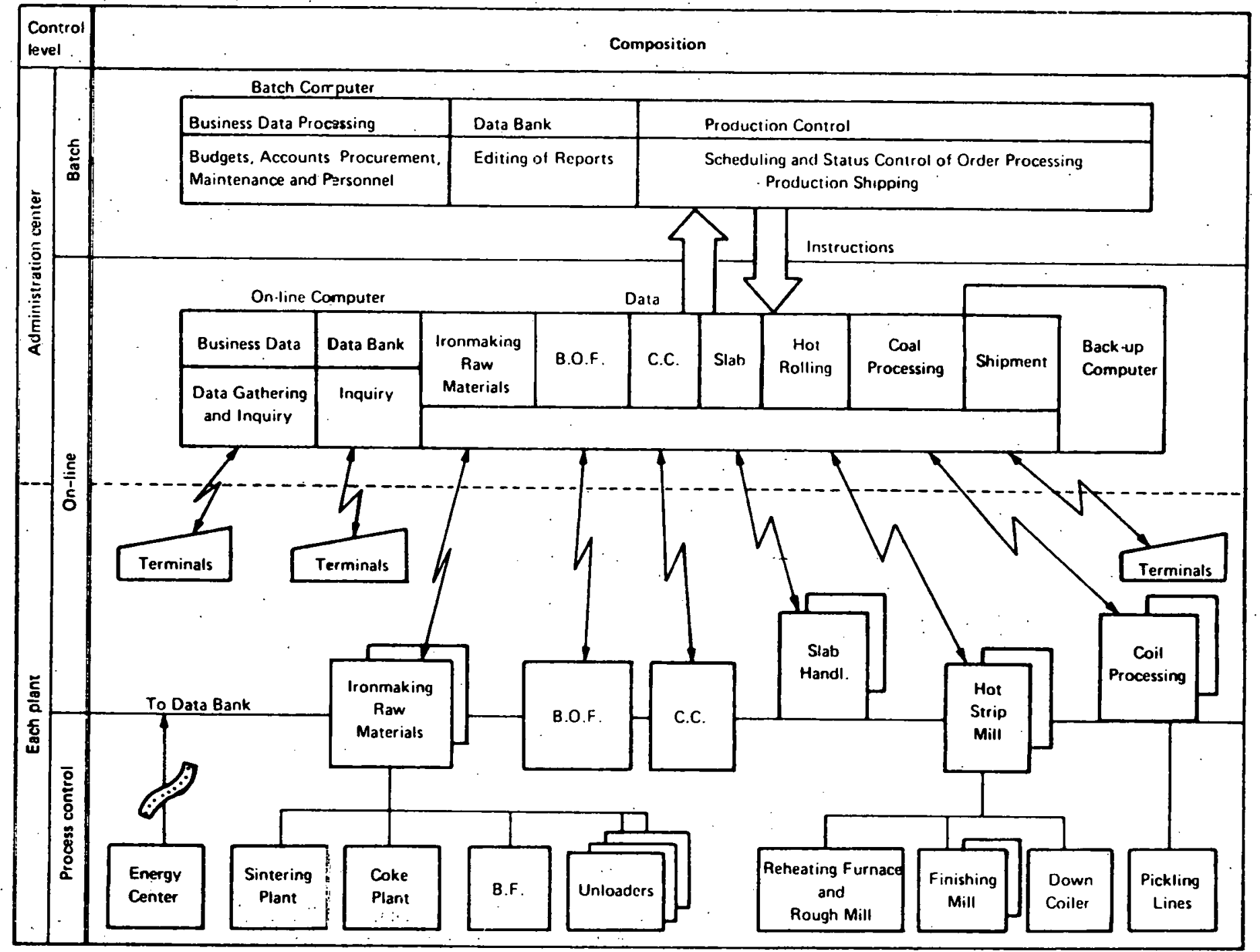

Source: Transactions, ISIJ, 1976.

FIGURE II-16 THE OITA HIERARCHICAL COMPUTER SYSTEM 
TABLE $\|-14$

\section{RESULTS FROM PROJECT ON HIERARCHICAL COMPUTER CONTROL SYSTEMS - PURDUE LABORATORY FOR APPLIED INDUSTRIES CONTROL}

- Comprehensive steady-state model of the blast furnace.

- Simplified geometric analog model of ingot heating and cooling which allows on-line optimization of the task.

- Optimization models of soaking pit, slabbing mill, and associated units; these techniques are adaptable to other parallel and sequential steel mill processing units.

- Overall steel mill simulation model.

- New technique for carrying out the adaptive control in establishino rolling mills.

- Roliability study simulation scheme.

- A.new heuristic computer-based algorithm for optimization of the scheduling of steel plant production.

- Simulation of a rail transportation system within the plant.

- Study of intercomputer communication techniques to select the best for incorporation into a proposed hierarchical computer control system.

- Technical feasibility and specifications of computer capabilities necessary for an on-line defect detection system for strip steel products from hot and cold rolling mills, pickling lines, temper mills, coating lines.

- Serics of simulation techniques for the study of manpower requirements and man/machine interface needs for all steel mill operations as well as those for other industries.

Source: Williams, 1980.

- Some of the lowor level arca or processes are iul under dynamic control. The blast furnace is perhaps the hest example of a pracess unit in which closed-loop control technology is not state of the art, and this precludes higher level supervisory control.

- Present-day computere and control inatruments manufacturud by different companies have poor compatibility, which makes it difficult to interconnect them.

- The mass of data to be analyzed is staggering. Inland Steel's Indiana Harbor plant, for instance, requires that track be kept of about 7,000 ingots, 15,000 slags, 50,000 billets or bars, and 30,000 finished products at any one time, since the plant produces more than 8 million tons of raw steel per year (Sugarman, 1978). The problem is one of timely data collection and retrieval under tight cost constraints. 
- Production supervision involves difficult non-linear programming. Reaction kinetics, energy transfer rates, equipment breakdown or jamming probability, and cost/quality trade-offs are all variables that are not yet well enough in hand for any cost-effective supervisory control to be possible. The need clearly is for a major basic and applied research effort that is not likely to pay off for some time, especially considering the diversities of companies and process unit at any site.

\section{e. Role of the Federal Government}

Integrated computer system development for the steel industry is hampered by a number of considerable obstacles:

- The cost of R\&D work required is such that few, if any, single companies can afford it.

- Any algorithm, once developed, may well be so plant-specific that it might be very difficult to derive from models applicable to other plants.

- An optimization model is only as good as the optimization criteria used. For instance, it may be difficult to take into account the "goodwill" value of satisfying a customer according to schedules different from the most cost-effective ones in the hope of increasing the company's volume of business with him.

- The present internal accounting system of domestic companies does not give a solid basis for cost optimization.

- Many facilities are too old to even be candidates for total computer integration.

Government support of steel company efforts in collecting and analyzing timerelated data for the development of dynamic models might well shorten the time needed for development of such models.

We note that many of the instrumentation and process control needs are unique to the iron and steel industry. High developmental costs and limited markets for any sensors and instrumentation developed do not make the steel industry a particularly attractive market for instrumentation and control companies. The steel industry has the technical resources and facilities to undertake the development and implementation of these concepts if they are shown to be cost-effective. However, the initiation of such projects has been hampered by economic constraints, financial limitations, and capital expenditure for more pressing problems, such as regulating agency-mandated projects unrelated to energy considerations. With Government support of cost-shared projects, the elapsed time for the commercial acceptance of sound, economically viable projects would be undoubtedly shortened. 


\section{BIBLIOGRAPHY}

American Iron and Steel Institute, “Annual Statistical Report," 19 79.

American Iron and Steel Institute, "Energy Conservation in the Steel Industry," 84th General Meeting, May 1976.

American Iron and Steel Institute, "Report to U.S. Department of Energy on Energy Efficiency Improvement and Recovered Material Utilization," 1979.

Anon., "Granite City Steel Announces Capital Improvement Program - Slab Caster and OBM-S," Iron and Steel Engineer, April 1979.

Anon.. "National Blueprints Big BOP Shhop Conversion," 33 Metal Producing, No: vember 1979.

Anon., Project Evaluation System - Input Data Form, "Melting Direct Reduced Iron Ore," DOE, April 12, 1979.

Anon., "Transactions ISIJ," 16, 1976, p. 589.

Arthur. D. Little, Inc., "Environmental Considerations of Selected Energy Conserving Manufacturing Options, Iron and Steel Industry," Vol. III. EPA Contract No. 68-032198, December 1976.

Arthur D. Little, Inc., "Research, Development and Demonstration for E'nergy Conservation: Preliminary Identification of Opportunities in Iron and Steelmaking," U.S. Department of Energy, NTIS SAN/1692-1, 1978.

Arthur D. Little, Inc., "State-of-the-Art Review of Computer Control in the Steel Industry," Division of Industrial Energy Conservation, Department of Energy, Subcontract No. K-1390 with EG\&G Idaho, Inc., June 1979.

Battelle Columbus Laboratories, "Evaluation of the Theoretical Potential for Energy Conservation in Seven Basic Industries," Federal Energy Administration, Contract 14-01-00Ul-1880, July 1975.

Battelle Columbus Laboratories, "Potential for Energy Conservation in the Steel Industry," report to Foderal Energy Administration, Contract Nu: C0-04-51874-00, May 1975.

Bleimann, K.R., M.D. Coward, and C.F. Hendrix, "An Update on Electric Arc Furnace Melting with Up to 100\% Sponge Iron," Iron and Steelmaker, June 1978:

Brian, P.L.T., H.B. Hales, and T.K. Sherwood, "Transport of Heat and Mass between Liquids and Spherical Particles in An Agitated Tank," AIChE Journal,15, 1969. 
Boudin, M., H. Jacobs, P.E. Nilles, "The OBM Steelworks of Forges de Thy-Marcinelle et Monceau," Iron and Steel Engineer, February 1979.

Callahan, J.T., "Heat Transfer Characteristics in Air Fluidized Solids up to $900^{\circ} \mathrm{F}$," Journal of Basic Engineering, June 1971.

Elliott; F.J., "The Energy Requirements for Melting Direct Reduced Iron Ore and Recycled Iron and Steel Scrap," Proposal to Division of Conservation, Industrial Systems, Department of Energy, March 15, 1979.

Elliott, J.F., J. Nauman, and K. Sadrnezhaad, "Heating and Melting of D-R Pellets in Hot Slag," Proceedings of 3rd I.I.S.C., Chicago, April 1978.

Fennell, A.G., and M.J. Virr, "Fluidized Bed Heat Treating," Heat Treating, December 1978 .

Gutfinger, C. and N. Abuaf, "Heat Transfer in Fluidized Beds," Advances in Heat Transfer, 10, Academic Press, 1974.

Haastert, H.P., H. Rellermeyer, and F. Weber, "BOF Technology and Metallurgy for Large-scale Processing of Sponge Iron Briquets," Iron and Steelmaker, June 1978.

Healy, G.W., "The Basic Oxygen Process," The Pennsylvania State University, 1966, pp 32-33.

Long, L.C., "Computer-based Process Control in the North American Steel Industry 1978," AISI 86th General Meeting, New York, Technical Session, May 25, 1978.

McGannon, H.E. (editor), "Making, Shaping, and Treating of Steel," U.S. Steel Corporation, 9th Edition, 1971.

Orton, J.P., P.J. Karos, and J.J. Bosley, "New Developments in Low Sulfur SteelNeeds and Production." American Iron and Steel Institute, 85th General Meeting, New York, May 26, 1977.

Papinchak, M.J., and T.W. Weaver, "Current Status of the Q-BOP Oxygen Steelmaking Process," Iron and Steelmaker, October 1978.

Reynoldson, R.W., "The Applications of Fluidized Bed Technology to Metal Processing," The Metallurgist and Materials Technologist, December 1978.

Sadrnezhaad, K., "Melting of .D.R Materials in Steelmaking Slags," Ph.D. Thesis, Massachusetts Institute of Technology, February 1979.

Schempp, E.G., "Increased Scrap Melting Capacity for Oxygen Steelmaking - The New OBM-S Process," Iron and Steel Engineer, December 1979. 
Sibakin, J., "Developments of Direct Reduction in the Iron and Steel Industry," Direct Reduced Iron Technology and Economics of Production and Use, AIME, 1980, pp. 3-8.

Staffin, R., "Conversion of Heat Treating Furnaces to Fluidized Bed Heat Treating," Proposal to DOE, and "DOE Project Status Report," Contract No. DE-FC0779CS40157, July 28, 1980.

Stone, J.K., "Increasing Scrap Usage by the L-D Process - Theory, Practice and Prospects," Iron and Steel Engineer, June 1963.

Sugarman, R., "Productivity II - Electrotechnology to the Rescue," IEEE Spectrum, 15, Octuber 1978.

Takahashi, E., M. Shimizu, Y. Oki. and O. Ishigami, "Heat Transfer Coefficient of Fluidized Bed and Its Application to Patenting Technique," Transactions ISIJ, 17, 1977.

Williams, T.J. "Hierarchical and Distributed Control Systems for Steel Mill Applications," Iron and Steel Engineer, April 1980, pp. 33-38. 


\section{ALUMINUM INDUSTRY}

\section{A. INDUSTRY CHARACTERIZATION}

\section{Description of Industry}

The U.S. aluminum industry consists of 12 primary aluminum producers with a total capacity of more than 5 million tons annually. Approximately 750 plants produce aluminum semi-fabricated products and about 90 secondary aluminum plants recycle aluminum. The principal operations of the primary aluminum industry consist of:

- Refining of bauxite ore by the Bayer process;

- Electrolytic reduction of alumina to aluminum by the Hall-Heroult process; and

- Prduction of semi-fabricated products.

The principal operations of the secondary aluminum industry consist of:

- Collection of scrap,

- Preparation of scrap, and

- Smelting of scrap to produce hot metal or ingot that is consumed principally by foundries.

\section{a. Energy Efficiency}

Significant quantities of energy are consumed in aluminum production, about 1 quad in 1979 , about $11 \%$ of which was in alumina and bauxite operations, $70 \%$ in smelting, and $19 \%$ in fabrication. Present-day U.S. aluminum facilities (average age, 20.5 years) were built largely at a time when fuels were plentiful and available at low cost. Energy was used as efficiently as could be economically justified by relative capital costs, productivity, and the like. The aluminum industry consumes a considerable amount of energy, mostly electrical. A large portion of this energy is consumed in smelting. The aluminum industry has reduced the energy used in smelting from more than $12 \mathrm{kWh}$ per pound of aluminum to about $8 \mathrm{kWh}$ per pound at present. The best available commercial U.S. Hall-Heroult technology requires about $6 \mathrm{kWh}$ per pound of aluminum. The pilot commercial operation of the Alcoa smelting process reportedly uses less than $5 \mathrm{kWh}$ per pound. Some of the hindrances in increasing energy efficiency have been difficulties in retrofitting existing facilities, limited availability of capital, the high cost of borrowing capital, and necessary expenditures for pollution abatement.

\section{b. Plant Locations}

(1) Primary Aluminum Industry - Figure III-1 shows the locations of alumina plants and aluminum smelters in the United States. Of the nine alumina plants, eight are located in the continental United States and the ninth is located in the Virgin Islands on the Island of St. Croix. Table III-1 lists the alumina plants in the United 
$\infty$

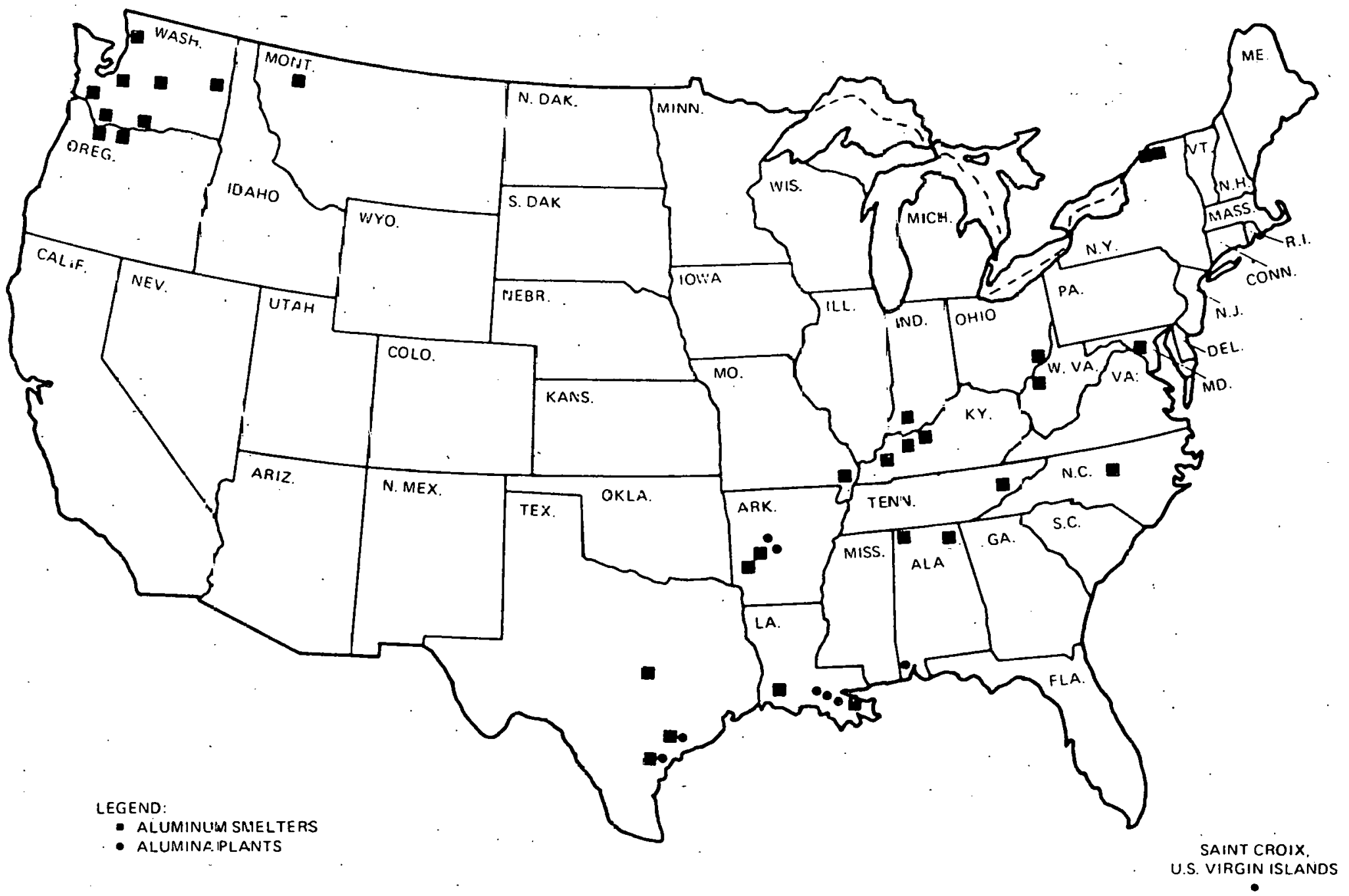

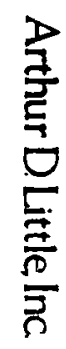

FIGURE III-1 LOCATION OF ALUMINA PLANTS AND ALUMINUM SMELTERS IN THE UNITED STATES 
TABLE III-1

\section{U.S. ALUMINA'PLANTS/CAPACITIES}

Capacity in 1976* *

(Equivalent Aluminum) (thousand short-tons/year)

Company and Plant

Plant

Company

Aluminum Company of America

1,405

Mobile, AL

515

Bauxite, AR

195

Point Comfort, TX

695

Martin Marietta

St. Croix, VI

237

Kaiser Aluminum and Chemical

$\begin{array}{ll}\text { Baton Rouge, LA } & 534 \\ \text { Gramercy, LA } & 417\end{array}$

Reynolds Metals Company

1,160

Hurricane Creek, AR

438

Cropus Christi, TX

722

Ormet Corporation *

Burnside, LA

313

Total U.S.

*A 66-34 joint venture between Consolidated Aluminum Corporation and Revere Copper and Brass, Inc.

* * Complete data not available for 1978.

* * At an equivalency factor of $\mathbf{1 . 8 9}$ ton alumina per ton of aluminum, the total capacity in 1976 is approximately 7.7 million short tons per year.

Sources: Mineral Commodity Profile, MCP.14, May 1978 and Arthur D. Little, Inc., estimates. 
States and gives their repective capacities. Individual plant capacities range from 1.385 million short tons per year to 370,000 short tons per year. The U.S. alumina plants are considered small by modern standards. Most newer installations have a capacity of at least 1 million and more typically 2 million tons per year. With the exception of the plant at St. Croix, which was built in the 1960's, all of the present U.S. plants are relatively old. The oldest plant was built by Alcoa at Mobile, Alabama, in 1940; two more (Kaiser at Baton Rouge and Reynolds at Hurricane Creek) were built prior to 1946; the rest began operating in the late 1940's and early 1950's.

Most of the alumina plants are located on the Gulf Coast because of the availability of natural gas. The two plants in Arkansas, at Hurricane Creek and Bauxite, were originally based on Arkansas bauxite. As the quality of Arkansas bauxite became poorer, these plants turned to foreign sources for part of their bauxite supply.

Some alumina plants are located near aluminum smelters. At Point Comfort, Texas, fur example, Alcoa hãs both an alumina plant. and an alıminum smeltor. The Reynolds alumina plant in Corpus Christi serves Alcoa's Texas smelters as well as the Reynolds smelter in Corpus Christi. Sources of alumina are therefore not always captive.

The twelve primary aluminum producers operate 32 aluminum reduction plants. Table III-2 lists these reduction plants and their respective capacities. All the plants except Alcoa's Palestine, Texas smelter, are based on Hall-Heroult technology. The Palestine plant is based on Alcoa's chloride process.

'T'he reduction plants are located primarily in three areas: along the Mississippi River system, in the Pacific Northwest and in upper New York at or near Massena. A decision on where to locate an aluminum smelter is determined by two factors: ascess to river systems for transportation of alumina and availability of what was originally low-cost power. Plants in Missouri, Kentucky, Indiana, Ohio, West Virginia, Tennessee, North Carolina, and Alabama take advantage of both the Mississippi River transport system and/or the availability of low-cost coal. The two plants in Massena, New York, have access to the St. Lawrence River for transportation and low-cost hydroelectric power. Plants in Washington (7), Oregon (2), and western Montana (1) are also located near hydroelectric power sources.

(2) Secondary Aluminum Industry - Most of the 90 secondary aluminum plants are located near heavily industrialized areas that give them proximity to a supply of scrap as well as to their customers. About $36 \%$ of the U.8. secondary aluminum production occurs within a 100 -mile radius of downtown Chicago. Another $20 \%$ of the production can be found within a similar radius of Cleveland, while the remaining $45 \%$ is located primarily near New York City and Philadelphia, in the Southwest, and in California.

(3) Others - Aluminum foundries are heavily concentrated in the Great Lakes states where most of the automotive plants are located. The Pacific states, the center of the aerospace industries, also have a large number of aluminum foundries. 


\section{U.S. PRIMARY ALUMINUM PLANTS/CAPACITIES}

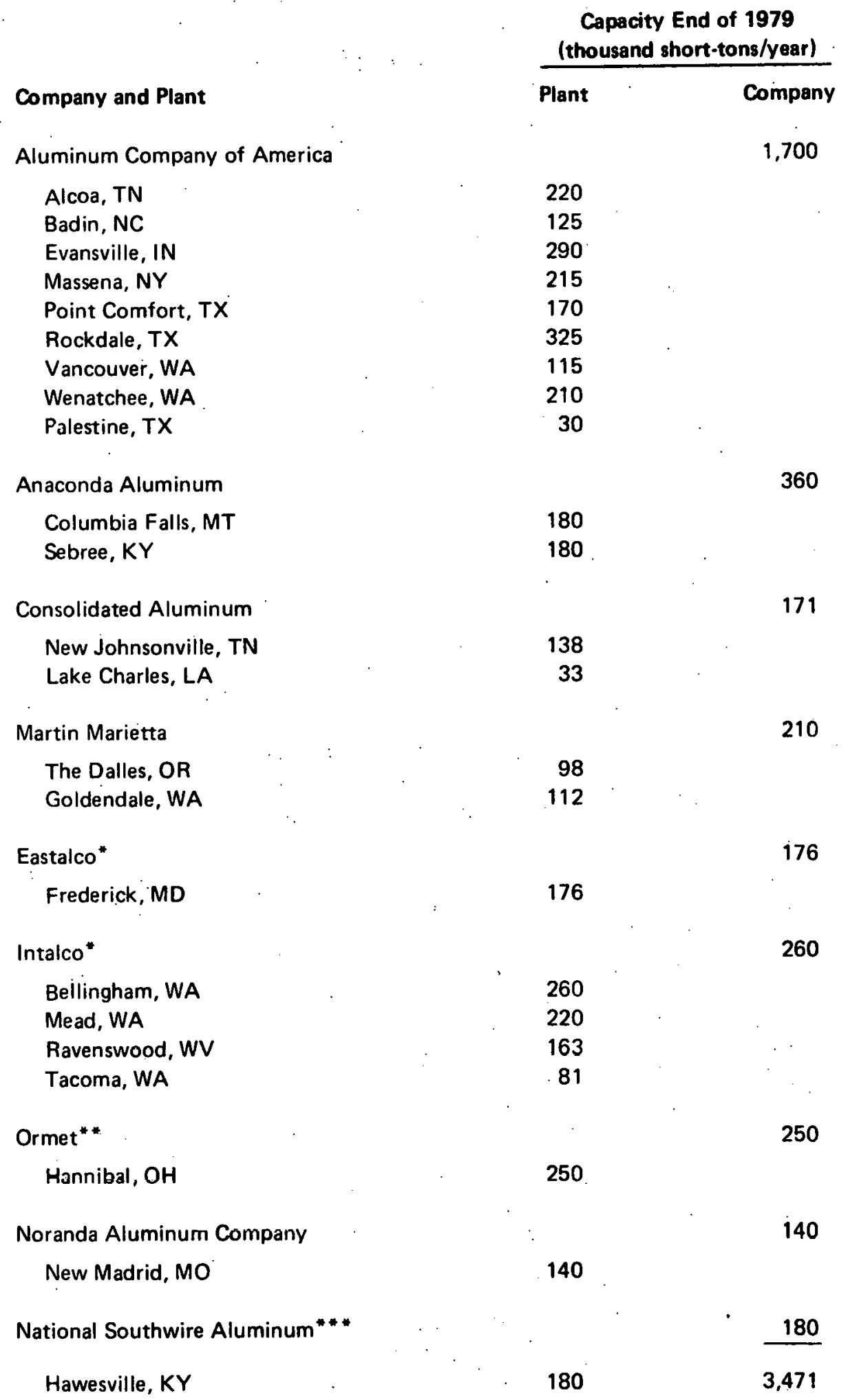


Plants producing mill products are distributed throughout the United States.

\section{c. Plant Categories}

(1) Primary Aluminum Industry - The U.S. aluminum industry has always depended on imports for most of its supply of bauxite. Typically, about $90 \%$ of the bauxite used in the United States is imported. The Arkansas bauxite deposits represent the only domestic source. Primary sources of U.S. bauxite are the Caribbean, northern South America, and Australia.

Within the United States, there are nine alumina production plants with a total capacity estimated to be equivalent to 4 million tons per year of aluminum (or approximately 7.7 million short tons per year of alumina) in 1976.

The 32 aluminum reduction plants in the United States had a total production capacity estimated at 5.3 million tons at the end of 1978 .

(2) Secondary Aluminum Industry - The secundury uluminum Industry is comprised of:

- Producers of alloy ingot, hot metal for foundrics and die casters, and bar and shot for steel de-oxidation; and

- Producers of secondary extrusion ingots used in extrusion plants.

Most of the production at the 90 individual secondary plants falls in the range of $3,000-50,000$ tons per year.

(3) Others - In addition there are about 1,400 fuundries in the United States that are primarily producing aluminum castings. About 960,000 tons of aluminum castings were produced in 1978. In addition, there are a number of companies and plants involved in the mannufacture of aluminum mill productia.

\section{Description of Established Processes}

\section{a. Primary Aluminum Production}

The major raw materials used in the primary U.S. aluminum industry are imported alumina and imported bauxite, which is domestically refined to alumina. Bauxite is refined to alumina by the Bayer process. The alumina is converted to aluminum by the Hall-Ileroult process.

(1) Bayer Process - In the Bayer process, shown in Figure III-2, finely ground bauxite ( -35 mesh), usually wet ground in spent digestion liquor, is digested at elevated temperatures under pressure. The digesting liquor contains sodium aluminate and free caustic.

Bauxites used in the production of alumina contain alumina trihydrate $\left(\mathrm{Al}_{2} \mathrm{O}_{3} \cdot 3 \mathrm{H}_{2} \mathrm{O}\right)$ and alumina monohydrate $\left(\mathrm{Al}_{2} \mathrm{O}_{3} \cdot \mathrm{H}_{2} \mathrm{O}\right)$. The U.S. aluminum industry 


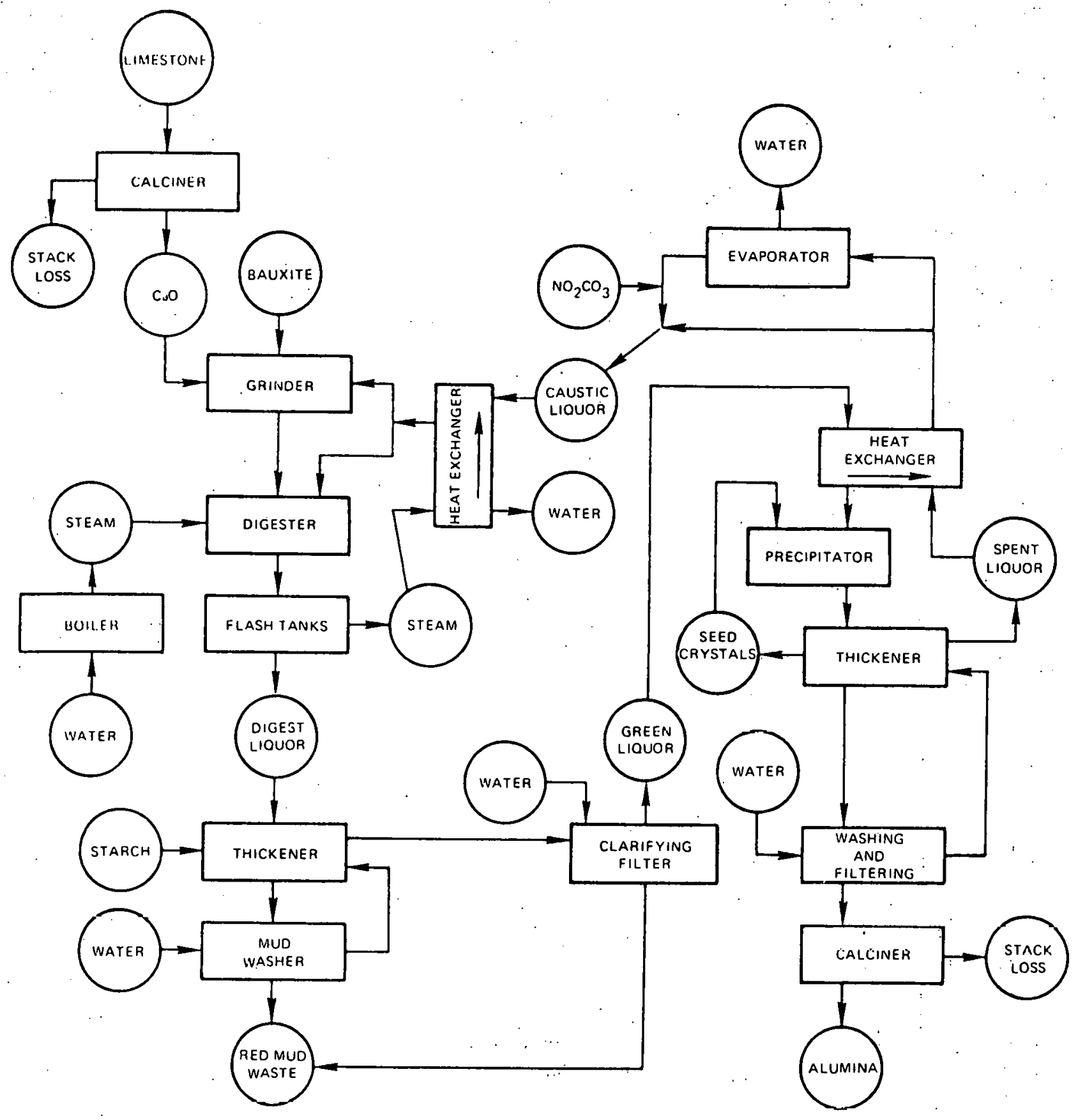

FIGURE III-2 BAYER PROCESS FOR PRODUCING ALUMINA 
has historically been based on bauxites from the Caribbean which are primarily trihydrates, whereas the European industry has historically been based more on bauxites that are typically much higher in monohydrates. The optimum reaction conditions vary with hydrate type as follows:

Trihydrate: $128-192 \mathrm{~g} / \mathrm{N} \mathrm{NaOH} @ 250^{\circ}-340^{\circ} \mathrm{F}$ (50-60 psi)

Monohydrate: $257-389 \mathrm{~g} / 1 \mathrm{NaOH} @ 390^{\circ} .570^{\circ} \mathrm{F}$ (up to $500 \mathrm{psi}$ )

Therefore, trihydrate ores are preferred because of milder operating conditions; however, the use of ores with increasing amounts of monohydrates is becoming necessary in the United States and the Caribbean plants. The average monohydrate content of bauxites imported into the United States ranges from 15-20\%. Digestion temperatures of $400^{\circ} \mathrm{F}$ and $200 \mathrm{psi}$ are becong common in U.S. alumina plants.

After the digestion step, the insoluble components of the bauxite - primarily oxides of iron, silicon, and titanium - are removed by thickening and filtration. The separated solids are known as red mud. Silicon is a particularly undesirable impurity in bauxite; especially in the form of elay, since it is readily dissulved in caustic liquor. Although the silica can then be precipitated as complex sodium aluminum silicates, these complex silicates cause problems with equipment scaling and filtration, in addition to the precipitate carrying a proportionate amount of sodium and alumina.

The Bayer process can be modified into the so-called combination processes. which permit treatment of high-silica bauxites. In the United States this process is used only on high-silica domestic ores which are used to produce alumina, principally. in the production of refractories.

Following digestion, which requires about 1 hour, the caustic slurry is cooled to its atmospheric boiling point of about $250^{\circ} \mathrm{F}$ in a series of flash tanks. The steam flashed off during cooling is used to preheat the new fresh bauxite-caustic mixture prior to entry into digestors. The digestion temperature is obtained either by steamjacketing the reaction units or, more commonly, by direct injection of steam. After cooling, the residue (red mud) is removed from the caustic slurry in thickeners. Some 10 to 20 pounds of starch are used as a flocculating agent with warm water or spent liquor to help settle the red mud in the thickeners from the pregnant liquor. The red mud discharged from the thickener goes to a mud washer filter where the mud is washed with water to recover the sodium hydroxide. This compound is sent back to the thickener and into the main pregnant liquor process stream. The quantity of red mud removed from the caustic slurry following digestion varies with the bauxite used and ranges from 0.33-2.0 tons per ton of alumina produced. About 0.8 ton of red mud per ton of alumina is typical in U.S. plants.

The resulting main process stream of sodium aluminate goes to a clarifying filter and the clarified "green liquor" then goes to precipitation. This liquor, clarified and diluted, is cooled in a heat exchangcr to $120^{\circ}-140^{\circ} \mathrm{F}$ and placed in large precipilation vessels that are seeded with alumina trihydrate crystals and mildly agitated to precipitate about $50 \%$ of the dissolved aluminum trihydrate. The precipitate is separated by settling and filtration. The product trihydrate is washed to minimize caustic soda losses during the filtration step. 
Spent liquor is a caustic solution which contains about half of the sodium aluminate present before the precipitation is recycled to the process for reuse. The free caustic content of the recycled liquor is increased by a combination of evaporation of excess water and the addition of makeup caustic. Caustic makeup is usually accomplished by adding caustic directly, but more typically it is produced by the addition of lime and soda ash. In the United States, the latter practice is more common. Typically, a portion of the spent liquor is taken off and evaporated to higher concentrations to precipitate sulfates. The sulfates may also be controlled by contacting the spent liquor with red mud during the clarification step, using spent liquor for dilution.

The consumption of chemicals is also a function of the composition of the bauxite. Most of the caustic is recycled, but makeup is needed to replace losses, including that amount consumed by silica as sodium aluminum silicate. Typical makeup requirements amount to $100-200$ pounds of soda ash and about the same amount of calcined lime per ton of alumina. Based on 1.8 tons of the limestone needed to produce a ton of lime, the lime requirements translate to $180-360$ pounds of limestone per ton of alumina.

In most U.S. Bayer alumina plants, the resulting alumina hydrate is calcined in rotary kilns which are operated at $2100^{\circ} \mathrm{F}$ to remove moisture and water of hydration. The resulting alumina is called pot-feed alumina which is the raw material used in the production of aluminum metal via the Hall-Heroult process.

(2) Hall-Heroult Process - This is an electrolytic reduction process in which alumina is dissolved in molten cryolite. The cryolite is electrolyzed in a cell in which the aluminum is liberated at the cathode; at the carbon anode, any oxygen liberated reacts with the carbon to produce carbon dioxides, largely $\mathrm{CO}_{2}$.

The basis of this process is that alumina dissolves readily in molten cryolite forming a eutectic at $16 \% \mathrm{Al}_{2} \mathrm{O}_{8}$ at $1725^{\circ} \mathrm{F}$. The electrolytic reduction is conducted at about 4.6 volts at or near the temperature of the electrolyte. The cell electrolyte contains $80-85 \%$ cryolite, $5-7 \%$ calcium fluoride, $5.7 \%$ aluminum fluoride, and $2-8 \%$ alumina.

Modern Hall-Heroult electrolytic cells consist of large steel boxes lined with insulating refractory and carbon. Carbon blocks at the bottom of the cells serve as the cathode in the electrolytic circuit. During electrolytic reduction, the aluminum metal is deposited as a liquid at the bottom of the cell on the surface of the carbon cathode.

Carhnn hlock cathodes constitute a more or less permanent installation. Typically, such cathodes last three to six years, about the same period as the life of the cell itself. The cathodes are replaced when the cell is taken out of service, rebuilt, and refitted. Although cathodes are purchased from carbon producers, anodes are produced at the aluminum plants.

The anodes are made of carbon; they are suspended in the electrolyte from steel rods that are connected to the anode bus. The carbon anodes used in the reduction 
cells are produced by two methods - Soderberg and prebake. In both systems, a combination of petroleum pitch and petroleum coke is used to produce the anodes.

In the Soderberg system, Soderberg paste is fed continuously into the top of the steel Soderberg casing. There the heat from the cell and current flow bakes the paste and removes the volatiles. In the prebake system, the volatiles are removed in a separate prebaking operation.

In the Soderberg system in which the prebaking of the anodes occurs above the cell, it. is difficult to recover the volatile hydrocarbons in the presence of fluorine and fluorides, carbon dioxide, and carbon monoxide, by a simple collection system. Also, power consumption is higher in the Soderberg system, because expensive electrical energy is used to bake the paste. For these reasons, it appears that the prebake system will he used in new facilities and will probably be substituted for Soderberg systens in existing plants.

I'he Soderherg system uses an anode which is baked by the reaction heat from the c.ell itself and the resistance heat genoratod by the current passing through the paste. The carbon paste, which is used as the anode material and is fed to the top of the anode casing. As the paste moves down, it is baked, forms the anode, and then is consumed as carbon dioxide is formed and released. The carbon that is removed is replaced by the paste injected into the top of the anode, and thus a continuous anodemaking process occurs.

In the prebake system, prebaked anodes are manufactured in a separate installation. They are made from a high-purity petroleum coke, which is ground, calcined, and blended with pitch to produce a paste which can be pressed into high-density shapes. Approximately 1975 pounds of petroleum coke, plus about 444 pounds of pitch, are required to produce a ton of anode carbon. The cokc is either purchased in the calcined state, or it is calcined at the plant and it is ground and mixed with pitch in a ratio of 4 pounds of ground calcined coke to 1 pound of pitch. These materials are mixed and pronocd into anodes of the required sliaje. The pressed unude blucks are then baked at temperatures up to $2000^{\circ} \mathrm{F}$ for periods as long as 30 days (baking and cooling period), after which they are fitted with steel connector rods which support the anodes and provide a connection to the anode bus. Molten cast iron is then poured into the anode socket to effect a goud electrical connection between the steel rod and the carbon anode. 'These anodes are consumed by oxidation of the carbon, and are replaced as required to prevent the steel from contaminating the cell electrolyte and the aluminum.

The cross-sestion of a typical cell and two types of Soderberg cells are presented in Figures III-3, III-4, and III-5.

Aluminum reduction cells operate continuously with periodic additions of alumina and electrolyte additives, replacement of anodes, and removal of molten aluminum. The aluminum is removed periodically at one- to three-day intervals and blended with the output of other cells to attain a uniform purity level. The blended material is degassed and cast into ingots or sows, or delivered as molten metal to fabricating plants. 


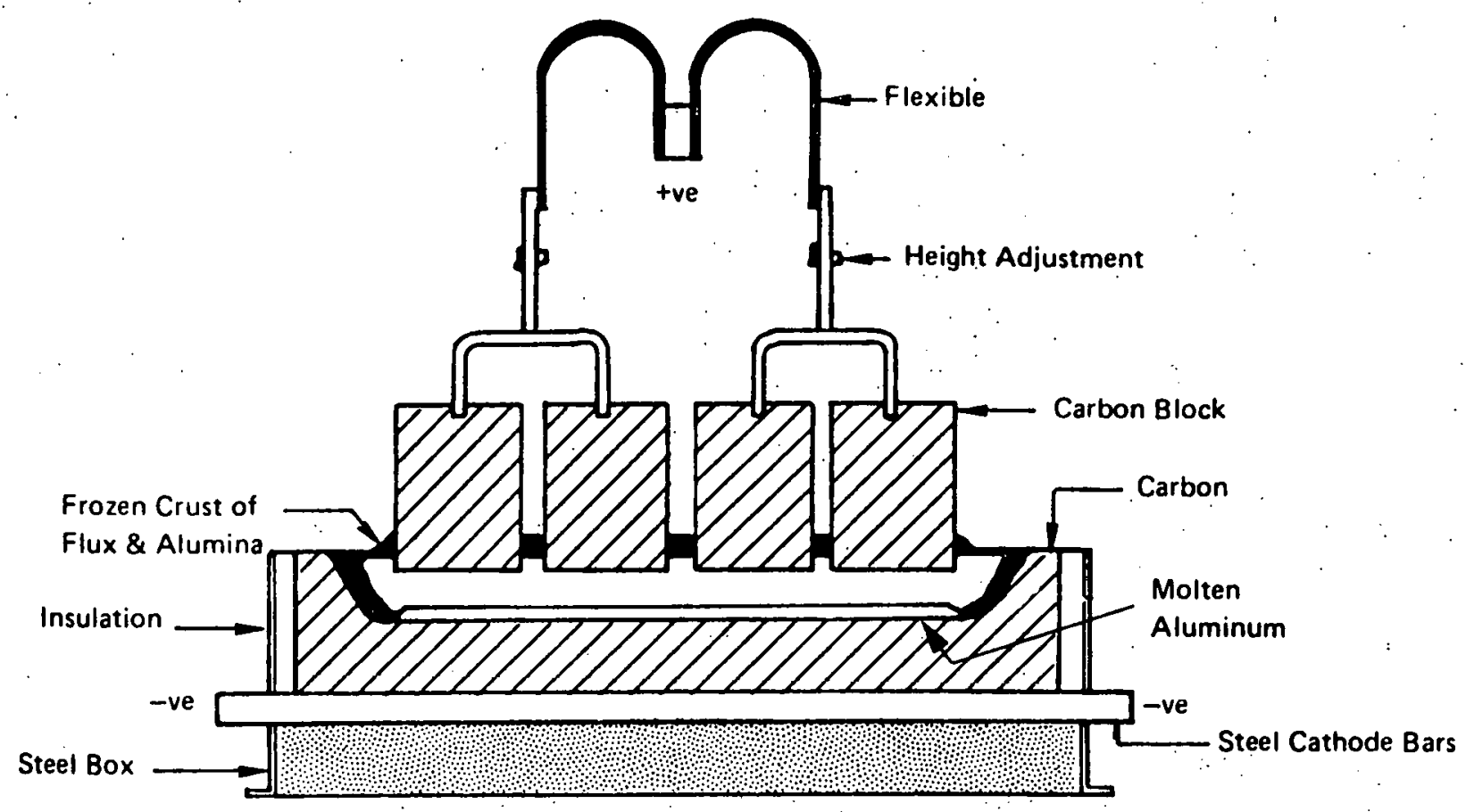

FIGURE III-3 AN ELECTROLYTIC FURNACE WITH BAKED BLOCK ANODE 


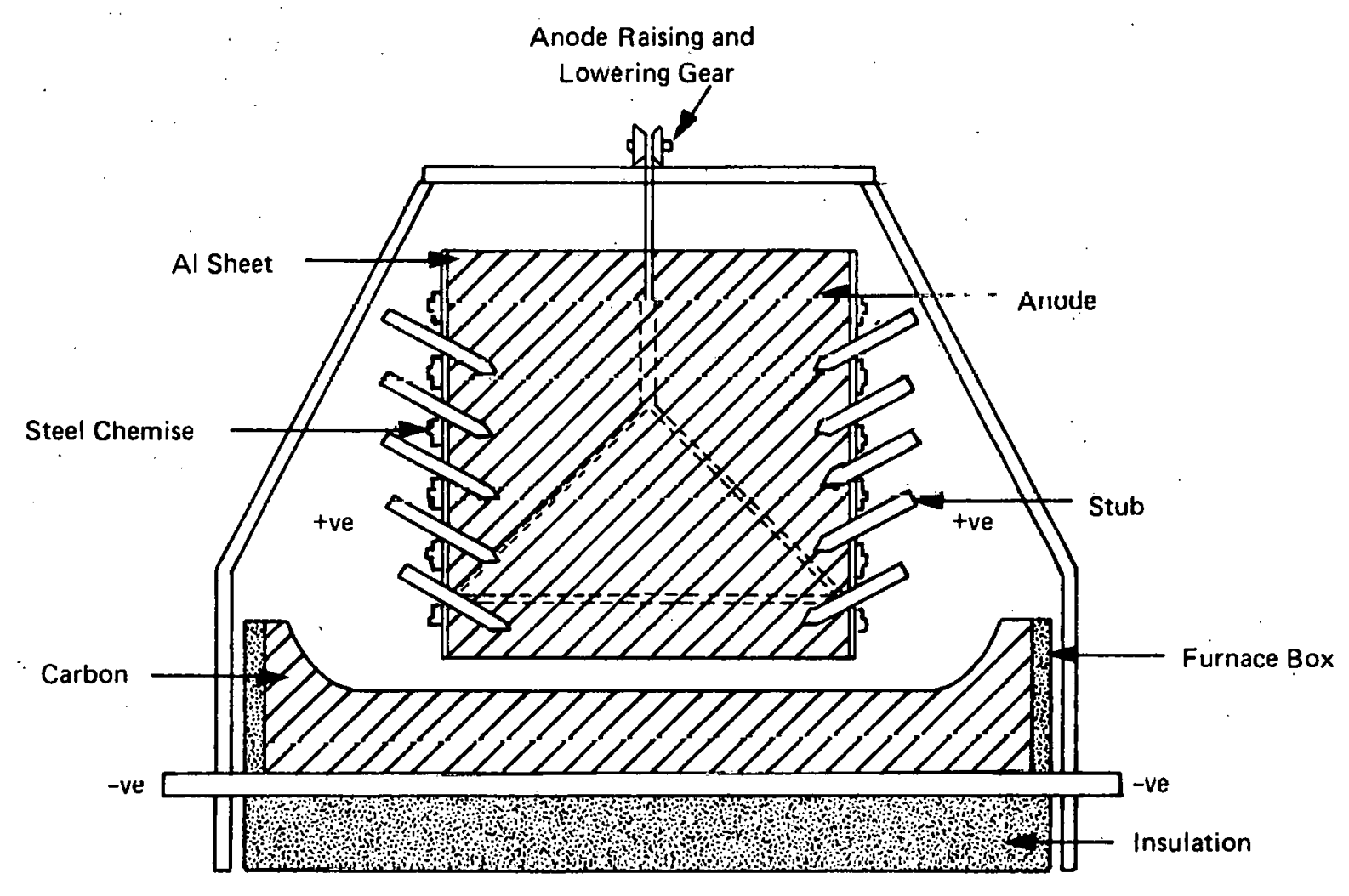

FIGURE III-4 ELECTROLYTIC FURNACE WITH SIDE-STUB SODERBERG ANODE 


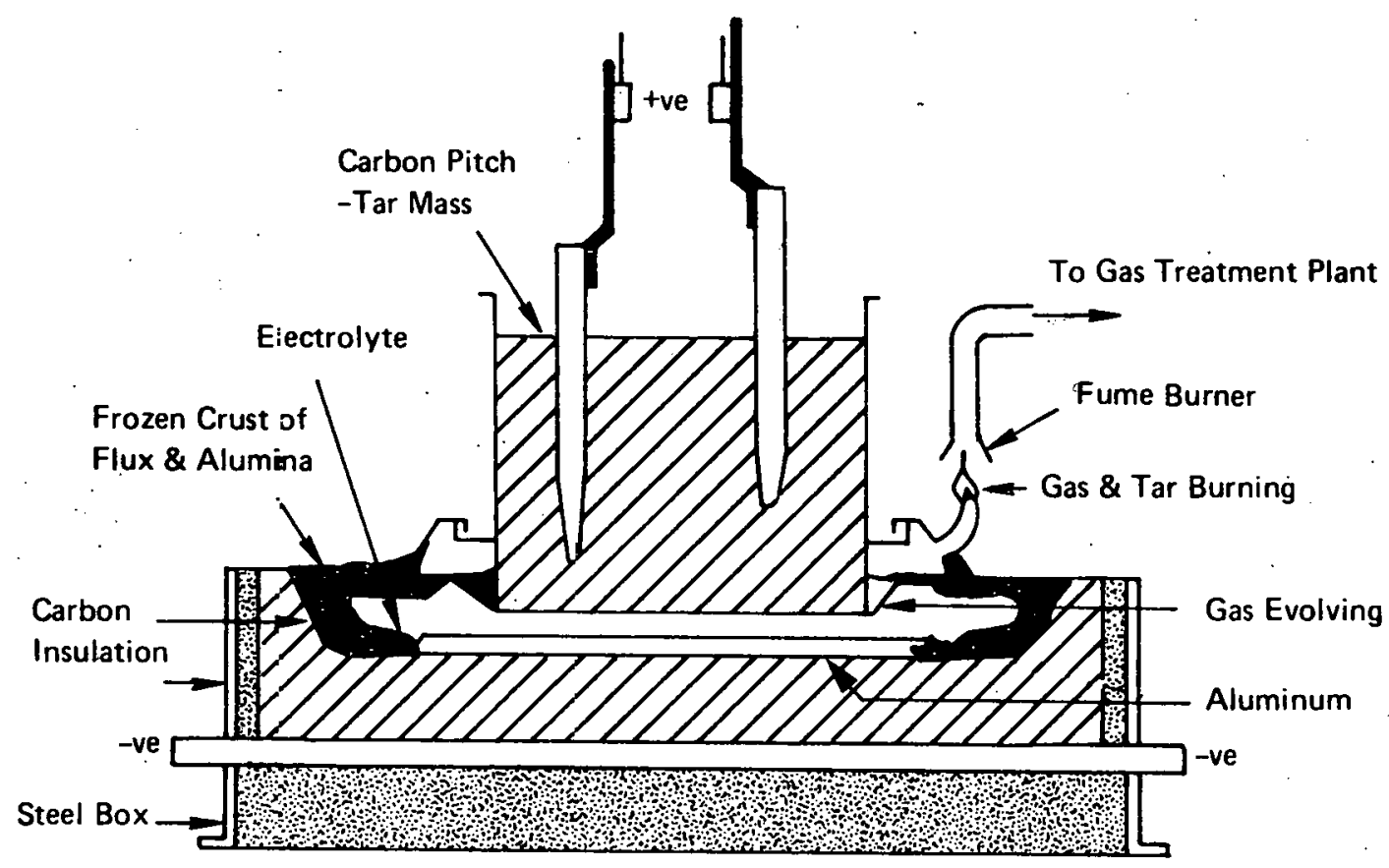

FIGURE III.5 ELECTROLYTIC FURNACE WITH VERTICAL STUBS 
In addition, aluminum, calcium fluoride (fluorspar), aluminum fluoride, and cryolite are added periodically to make up for losses of fluorine; which is released at the anode from the partial reduction of the electrolyte. Approximately 50 pounds of fluorine are released per ton of aluminum produced.

\section{b. Secondary Aluminum Production}

The secondary aluminum industry provides about $25 \%$ of the aluminum supply. It consists of numerous dealers and collectors, about 90 secondary aluminum smelters, and a few primary producers who are significantly involved in recycling. In this industry, scrap is gathered by collectors who accumulate various metals. The collectors then haul the scrap to a dealer (processor) who sorts it into various metal and alloy groups.

The scrap preparation methods vary according to the the type of scrap to be sorted. For example, new aluminum clippings, forgings, and solids, if clean, require no prcparation. If the oolido have iron incluaions or contain other contaminants, they are usually run through a shredder to reduce the size of the scrap and later through a magnetic separator to remove the iron.

Aluminum borings and turnings are charged into a crusher which reduces them to a uniform size. They are then dried in a rotary kiln-type dryer where oil and moisture are volatilized. Finally, the borings are passed over a magnetic separator where tramp iron is removed.

Most aluminum drosses, skimmings, and slags are processed by milling, screening, and magnetic separation to obtain an end-product with a minimum $60 \%$ to $70 \%$ metal that is suitable for charging into the melting furnace. Rich metallic skims normally do not require milling prior to use.

Nluminum cast (or sheet) containing massive iron pieces, or large quantities of iron, is processed in a "sweat" furnace where the aluminum is "sweated" away from the iron. Old scrap usually has enough free iron rivets, bushings, and other tramp attachments or contaminants to require shredding to small size before being subjected to magnelic separaliun.

Aluminum wire scrap is handled by wire chipping methods; wet preparation methods are also used, as well as rotary salt bath techniques for dross processing.

The main processing method used in the secondary aluminum industry is reverberatory (reverb) melting of aluminum scrap. The reverb furnaces are either gas- or oil-fired. The scrap is melted to specification hot metal or cast to specification ingots, and the resulting products are utilized by the foundry industry. 


\section{Energy Use Profile: Primary Aluminum}

\section{a. By Major Process}

In 1979 , the aluminum industry consumed just over 1 quad of energy $\left(1.041 \times 10^{15} \mathrm{Btu}\right) .{ }^{*}$ Of this amount, $11 \%$ was consumed in bauxite and alumina operations, $70 \%$ in smelting, and $19 \%$ in fabrication. Energy use by major process is discussed in the following subsections.

(1) Alumina Production - Bayer plant operations differ in certain respects since the bauxite that comes from the several Caribbean sources differs in composition. This, in turn, causes variations in the consumption of raw materials, chemicals, and thermal energy. The bauxite required to produce a ton of alumina via the Bayer process depends upon the alumina content of the bauxite, the amount of trihydrate and monohydrate present, and the inherent impurities, such as silica, iron, and titanium.

Power is consumed in the Bayer plants mainly for grinding the bauxite, with lesser quantities used for grinding lime and for driving mixers, rotary kilns, pumps, and the like. The power consumed in grinding depends upon the hardness of the bauxite. Power consumption per ton of alumina has been variously estimated at 200 $300 \mathrm{kWh}$ per ton of alumina. These estimates were made on the assumption that trihydrate bauxite was being fed to the plant, and on the basis that it had been previously crushed. With monohydrate bauxite, power consumption for grinding can be as much as $40 \%$ greater. Actually, about one-quarter of the bauxite imported into the United States arrives in the form of a crude, undried, uncrushed product. If one takes this into account and the fact that these imports contain up to $15-20 \%$ monohydrate, we believe that the average power consumption per ton of alumina is approximately $275 \mathrm{kWh}$ per ton of alumina.

Fuel is used in the refining stage, mainly to generate steam for digestion and evaporation, but also for firing the calcining kilns. Steam consumption has been estimated to vary as follows:

- Trihydrate-based bauxite plants: $3000-8000$ pounds of steam per ton of alumina; and

- Monohydrate-based bauxite plants: $4500-14,000$ pounds of steam per ton of alumina.

Most of the major alumina producers have their own limestone quarries because a high grade of lime - and thus limestone - is required to preclude introduction of impurities in the system. The lime calcination is carried out at the quarry or at the aluminum plant and therefore constitutes an energy requirement of the process.

"Based on 10,500 Btu per kWh. 
Since limestone requirements range from $0.09-0.18$ ton per ton alumina and the heat requirements for calcination are $4.25 \times 10^{\circ}$ Btu's per 1.8 tons of limestone, the thermal energy requirements for lime calcination range from $0.21-0.43 \times 10^{8}$ Btu's per ton of alumina.

Thermal energy is also required for the calcination of alumina. It has been variously estimated to range from 2.7-5.0 $\times 10^{6} \mathrm{Btu}$ per ton of alumina, depending on the size and efficiency of the calcination system. We believe that the average fuel requirement for calcination in the U.S. Bayer plants runs about $4.0 \times 10^{\circ}$ Btu's per ton of alumina.

Table III- 3 summarizes the ranges of materials and energy requirements in U.S. alumina plants and the considered averages.

TABLE III-3

\section{BAYER ALUMINA PRODUCTION \\ RANGE OF REQUIREMENTS AND CONSIDERED AVERAGE REQUIREMENTS Present U.S. Operations - Conventional Technology}

Range

Raw Materials:

Bauxite

Limestone

Soda ash

Starch

Power:

Fuel:

Stcam gencration

Line calcination

Alumina calcination

TOTAL ton/ton alumina

$$
\begin{aligned}
& .09-.18 \\
& .05-.1 \\
& .005-.01
\end{aligned}
$$

$k W h / t o n$ alumina

$200-300$

$10^{6} \mathrm{Btu} /$ ton alumina

$$
\begin{gathered}
4.4-11.3 \\
.21-.43 \\
2.8-5.0
\end{gathered}
$$

U.S. Industry Average

ton/ton alumina

2.40

.133

.075

.006

$k W h /$ tur alumirra

275

$10^{6} \mathrm{Btu} /$ ton alumina

1.30

.31

4.00

11.61

(2) Aluminum Production - In aluminum production, energy is consumed primarily in the form of electric power, but thermal energy is also required for anode baking and casting. Modern Hall-Heroult cells, using a prebaked anode system, typically draw 150,000-160,000 amperes operating across a relatively small voltage drop, typically in the range of 4-5 volts; a 4.6-4.7 voltage range is common in the U.S. industry. 
The electrolysis step is, by far, the most energy-intensive in the aluminum production sequence. Electricity consumption per short ton of aluminum ranges broadly from a low of 12,400 to as high as $20,000 \mathrm{kWh}$ per short ton of aluminum. Historically, the United States has had the advantage of relatively low electricity costs, so that to reduce capital investments, electricity consumption has been moderately high, in the range of $14,000-18,000 \mathrm{kWh}$ per short ton of aluminum. The average is currently about $15,600 \mathrm{kWh}$ per short ton.

Electricity consumption in the smelting of alumina to aluminum metal is basically the result of a trade-off between power costs and capital investments required in the cell. In France and Switzerland, the power costs have been relatively high compared to the United States. Producers have reduced power consumption considerably - to the range of $12,400-13,600 \mathrm{kWh}$ per short ton. On the other hand, countries with cheap power costs, such as Canada and Norway, report 15,000-17,250 kWh per ton. We have recently learned that power consumption in the best cell lines can be as low as $12,000 \mathrm{kWh} /$ ton in prebaked Hall-Heroult-type cells. This is about the minimum attained to date in the most modern cells, but it is a target that could be reached if all the cell lines were modernized by installation of large Hall-Heroult-type prebaked cells using the most modern technology. This would require an enormous investment by industry and would be difficult to justify, unless the cost of electricity increases very dramatically, at which time the oldest, most inefficient plants would be modernized or closed down.

In addition to the electricity required in the aluminum smelters, thermal energy also is required for calcining green coke and baking anodes and for casting sows or semi-finished forms.

Most aluminum smelters today are purchasing calcined coke, so the energy requirements for calcination of petroleum coke are presently being borne by the refineries prior to shipment to the aluminum smelters. The fuel for calcination is no longer a major consideration at the smelter. With the fuel availability and waste gases and waste heat at the refinery, the calcination is more logically carried out on a larger scale at the refinery rather than on a small scale at the carbon plants of the aluminum smelters.

However, energy is required to produce the prebaked anodes. Various estimates fall in the range of 2.3 to $3.6 \times 10^{\circ}$ Btu's per ton of aluminum. We believe that the average requirement in modern baking installations would amount to about $2.6 \times 10^{\circ}$ Btu's per ton of aluminum. This is the net energy input to the baking; i.e., the external fuel used in baking. Combustible gases and part of the tar used in the anode forming are baked out in the anode-baking operation; later they are burned at the top of the baking ovens with air lances to control pollution emissions and provide some direct heat to the baking. The amounts lost are modest, roughly 222 pounds of material per ton of anodes, but totalling only about 100 pounds of fossil fuel values per ton of aluminum. The Btu value of the material would be about 10,000-12,000 Btu's per pound, but in a typical layout baking operation it would be extremely difficult to recover this material. 
Requirements for casting range from $1.5 \times 10^{\circ}$ Btu's per ton of aluminum for simple casting of the aluminum metal in the form of sows to a requirement of $11 \times 10^{6}$ Btu's for production of semi-finished forms, such as a product mix of $35 \%$ rolling slabs, $.35 \%$ extrusion billets, and $30 \%$ sows. However, we believe the average to be about $4 \times 10^{8}$ Btu's per ton of aluminum for casting. This means that the total average thermal energy requirement is about $6.6 \times 10^{6} \mathrm{Btu}$ 's per ton.

Table III- 4 presents a range of materials added per ton of alumina and the estimated average additions or consumptions of alumina, cryolite, aluminum fluoride, calcium fluoride, petroleum coke, and petroleum pitch. It also presents the range of power and fuel consumption and considered averages in U.S. smelters.

\section{TABLE III-4}

\section{HALL-HEROULI ALUMINUM SMELTING RANGE OF REQUIREMENTS AND CONSIDERED AVERAGE REOUI!REMENTS \\ Present U.3. Prebuked Plant Operation - Conventional Technology}

Range

Raw Materials:

Alumina
Calcinated petroleum coke
Pitch
Cryolite
Aluminum fluoride
Calcium fluoride

Power:

Fuel: Baking anodes
Casting

"Simple casting of sọws. ton/ton of aluminum

$1.91-1.95$

$0.43-0.60$

$0.10-0.20$

$0.01-0.05$

$0.01-0.05$

$\mathrm{kWh} /$ ton of aluminum

$14,000-18,000$

$10^{6} \mathrm{Btu} /$ ton of aluminum

$2.3-3.6$
$1.5-11.0$
U.S. Industry Average

ton/ton of aluminum

1.93

0.52

0.15

0.035

0.03

0.003

$\mathrm{kWh} /$ ton of aluminum

15,600

$10^{6} \mathrm{Btu} /$ ton of aluminum

2.6

$1.5^{*}$

\section{b. Byproducts}

Processes involved in producing semi-fabricated aluminum products and byproducts were not available. 


\section{c. By Fuel Usage}

Of the approximately 1 quad of energy $\left(1.041 \times 10^{16} \mathrm{Btu}\right)$ consumed by the primary aluminum industry in $1979,68 \%$ of this energy was in the form of electricity, which was used almost entirely in smelting. The energy needs of the aluminum industry, by fuel type, were distributed as follows: coal, $45 \%$; hydro, $11 \%$; natural gas, $32 \%$; and petroleum $12 \%$. Thus, $44 \%$ of the aluminum industry's energy needs were supplied by natural gas and petroleum. For comparison, $73 \%$ of the total energy needs of the United States are supplied by petroleum and natural gas.

\section{Energy Use Profile: Secondary Aluminum}

Table III-5 summarizes the energy use, by type of scrap, in aluminum scrap preparation. Tables III- 6 and III-7 summarize the energy requirements for reverbmelting of aluminum scrap to alloy 380 ingots and hot metal (alloy 380 ). Table III-8 presents the energy requirements for recycling aluminum can to hot metal for can sheet stock. The tables show that the energy requirements range from 8.7 to 19.6 million Btu's per net ton of product (alloy 380 ingot, hot metal; alloy 380 , can stock).

TABLE III-5

\section{ENERGY USE IN SCRAP PREPARATION}

$\begin{array}{lc}\text { Aluminum Scrap Type } & \begin{array}{c}\text { Energy Required } \\ \text { (Million Btu per } \\ \text { Net Ton Prepared Scrap) }\end{array} \\ \text { Clippings } & \\ \text { Borings and turnings } & 0.9 .1 \\ \text { Drosses } & 3.05 \\ \text { High-iron scrap } & 1.06 \\ \text { Sheet and cast scrap } & 9.28 \\ & 1.18\end{array}$

\section{B. ALUMINA MANUFACTURE AND ALUMINUM REDUCTION}

\section{Conventional Technology}

\section{a. Current Practice}

Aluminum is produced by the Bayer-Hall-Heroult process. The first step (Bayer process) consists of the manufacture of alumina from bauxite ores; the second is an electrolytic step (Hall-Heroult) in which the alumina, dissolved in a cryolite melt, is reduced to aluminum metal.

The Bayer-Hall-Heroult process, in use for more than 80 years, is, with one exception, the only process used throughout the world for producing aluminum. The exception is a chloride electrolytic prucess developed by Alcoa (the Alcoa smclting 
TABLE III-6

ALUMINUM: REVERB FURNACE MELTING ALUMINUM SCRAP TO ALLOY 380 INGOTS

(Step Number) Process

(1) Reverb melting

Natural gas

Electrical energy

Sodium chloride

KCL by flotation

Cryolite

Aluminum fluoride

Gaseous nitrogen

Gaseous chlorine

Refractory

Silicon

Scrap-clippings

Scrap-borings \& turnings

Scrap-concentrations

Scrap-sheathed sows

Scrap-sheet and cast
Cu. ft.

$\mathrm{Kw} \mathrm{hr}$

Net ton

Net ton

Nét tun

Net ton

Net ton

Net ton

Net ton

Net ton

Net ton

Net ton

Net ton

Net ton

Net ton

\section{Units per \\ Net Ton of \\ Product}

10000.0000
14.8000
0.0420
0.0420
0.0040
0.0200
0.0053
0.0013
0.0018
0.0500
0.1110
0.3330
0.3330
0.1110
0.1670

\author{
Energy Required \\ per Unit \\ (million Btu)
}

$$
\begin{array}{r}
0.001000 \\
0.010500 \\
0.490000 \\
2.590000 \\
155.000000 \\
51.400002 \\
2.900000 \\
18.000000 \\
26.600000 \\
\\
0.910000 \\
3.050000 \\
1.060000 \\
9.280000 \\
1.180000
\end{array}
$$

Subtotal

Kw hr

2.8500

Electrical Energy
Kw hr

23.4000

Electrical energy
Total process energy

Air pollution control

Tntal pollution

control energy

Space heating

Natural gas
Cu. ft.

50.0000

$$
0.010500
$$

Subtotal

$\begin{array}{ll}0.010500 \\ \text { Subtotal } & \frac{0.25}{0.25}\end{array}$

0.25

\begin{tabular}{ll}
0.001000 & 0.05 \\
Subtotal & 0.05 \\
& 0.05 \\
\hline
\end{tabular}

0.03

0.03

14.76

25

\author{
Million Btu per \\ Net Ton of \\ Product
}

10.00

0.16

0.02

0.11

0.62

1.03

0.02

0.02

.05

0.10

1.02

0.35

1.03

0.20

14.73

15.06

Total energy per net ton of product

** - The energy content of these alloying elements is not included in the total energy reported in this table. 
TABLE III.7

ALUMINUM: REVERB FURNACE MELTING ALUMINUM SCRAP TO HOT METAL (ALLOY 380)

(Step Nümber) Process

(1) Reverb melting

Natural gas

Electrical energy

Sodium chloride

$\mathrm{KCL}$ by flotation

Cryolite

Aluminum fluoride

Gaseous nitrogen

Gaseous chlorine

Refractory

Silicon

Scrap-clippings

Scrap-borings \& turnings

Scrap-concentrations

Scrap-sheathed sows

Scrap-sheet and cast

Total process energy

Air pollution control

electrical energy

$\mathrm{Kw} h r$

23.4000

Cu. ft.

14570.0000

$\mathrm{Kw} \mathrm{hr}$

14.8000

Net ton

0.0420

Net ton

0.0420

Net ton

0.0040

Net ton

0.0200

Net ton

0.0053

0.0013

0.0018

0.0500

0.1110

0.3330

0.3330

0.1110

0.1670

Net ton

Cu. ft.

50.0000

Space heating

natural gas

Total pollution

control energy

* Total space heating

energy

* Total energy per

net ton of product

\author{
Energy Required \\ per Unit \\ (million Btu)
}

0.001000

0.010800

0.490000

2.590000

155.000000

51.400002

2.900000

18.000000

26.600000

0.910000

3.050000

1.060000

9.280000

1.180000

Subtotal

\author{
Million Btu per \\ Net Ton of \\ Product
}

14.57

0.16

0.02

0.11

0.62

1.03

0.02

0.02

0.05

0.10

1.02

0.35

1.03

0.20

19.30

19.30

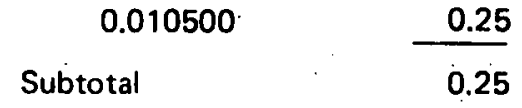

0.25

0.001000

0.05

Subtotal

0.05

0.05

19.60

"* - The energy content of these alloying elements is not included in the total energy reported in this table. 
TABLE III-8

ALUMINUM: RECYCLING ALUMINUM CANS TO HOT METAL FOR CAN SHEET STOCK

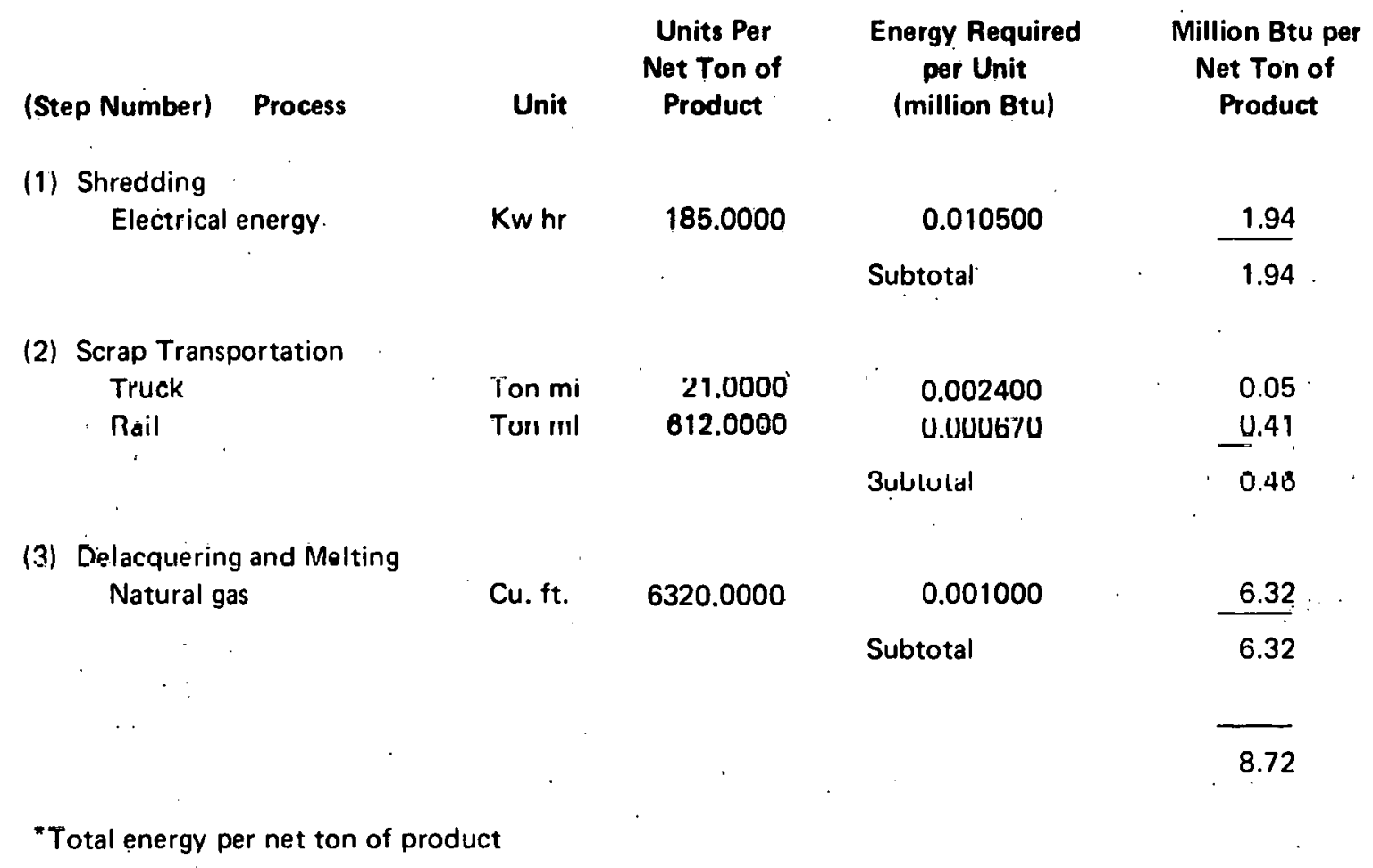

process). Also, studies of processes to produce alumina from domestic ores other than bauxite are being studied extensively, but none is being commercially practiced at the present time.

With respect to conventional Bayer processing in the area of alumina calcination the principal development has been flash calcining, which consumes about $30 \%$ less energy than conventional rotary kilns.

With reepcet to alternative process options for the production of alumina, all efforts in the United States and other industrialized countries are currently being directed toward recovering alumina from domestic alumina-bearing raw materialslargely clays (kaolin clays in Georgia and South Carolina). The alternative processes (hydrochloric acid leaching, liquid ion exchange, nitric acid process, liquid ion exchange, Toth alumina process) generally consume more energy than the conventional Bayer process. The successful development of alternative alumina processes, however, would extend the aluminum resource base.

All Hall-Heroult cells have essentially lhe same basic design, with the exception that there are two types of anode (prebake and Soderberg). The cell consists of a horizontal cathode of carbon situated in a carbon-lined steel bath; the anodes are 
suspended immediately above the cathode so that the separation between them and the aluminum pool that forms on the cathode is approximately 2 inches. The electrolyte is molten cryolite, $\mathrm{Na}_{8} \mathrm{AlF}_{8}$, with an excess of $\mathrm{AlF}_{8}$ at $1724^{\circ}-1787^{\circ} \mathrm{F}$, Also, it is common practice to add lithium carbonate to the cell to improve its conductivity. The Soderberg anode is formed continuously in situ from a paste of petroleum coke and pitch heat by the cell. The terms horizontal and vertical applied to the Soderberg cell refer to the configuration of the anode current collectors and not to the attitude of the anode. The operating currents fall in the range of 50 to $250 \mathrm{kA}$ with anode current densities of $600-800$ amperes per square foot $\left(\mathrm{A} / \mathrm{ft}^{2}\right)$.

In operation, alumina produced by the Bayer process, is dissolved in the cryolite to the extent of about $5 \mathrm{wt} \%$. The alumina is preheated by pouring it onto the crust of frozen electrolyte that insulates the top of the cell. The alumina is then added by breaking the crust periodically. Overfeeding a cell leads to sludge formation which is difficult to disperse and can result in days of downtime. It is usual to control the alumina addition by depleting the cell leading to an anode effect, which is a large increase in voltage at fixed current associated with the formation of a gas film at the anode. The anode effect occurs when the $\mathrm{Al}_{2} \mathrm{O}_{3}$ content of the bath is too low. (The monitoring and control of the anode effect are discussed in more detail in a later section.) The principal operational variable is the anode/cathode distance (ACD). In a normal cell, the level of the aluminum cathode pool rises by about 1.5 to 2.0 centimeters per day, about the same rate as a prebaked cathode is consumed. Adjustment, in principle, is required only when the aluminum is tapped off; however, anode consumption is not uniform and, although this effect is self-compensating, external correction is often beneficial. The importance of the ACD will become more apparent with the discussion of energy losses below.

The theoretical energy requirement for the reduction of alumina in an electrolytic cell with a consumable carbon anode is calculated to be $2.85 \mathrm{kWh}$ per pound of aluminum, based on the following reaction:

$$
2 \mathrm{Al}_{2} \mathrm{O}_{3}+3 \mathrm{C} \rightarrow 4 \mathrm{Al}+3 \mathrm{CO}_{2},
$$

This is based on a reversible voltage for this reaction of 1.17 volts. In practice, the production of aluminum consumes from $6-8.5 \mathrm{kWh}$ per pound at cell voltages of 4.5 volts and higher. The breakdown of the voltage drop across a typical prebake cell operating at 145 kiloemperes and a 2 -inch ACD is given in Figure III- 6 . The irreversibility of the electrochemical processes $(0.5$ volt $)$ and the resistance of the aluminum carbide film formed at the interface of the aluminum pool with the carbon cathode $(0.4$ volt) make significant contributions. However, it is apparent that the predominant loss is due to the resistance of the electrolyte which, in turn, is strongly dependent on the ACD.

The ACD is typically maintained close to 2 inches to prevent shorting due to surges in the aluminum pool that result from the magnetic field in and around the cell. This problem becomes more intense the bigger the cell and the higher the current density, though improved understanding of these interactions has minimized their effect in modern cells. 


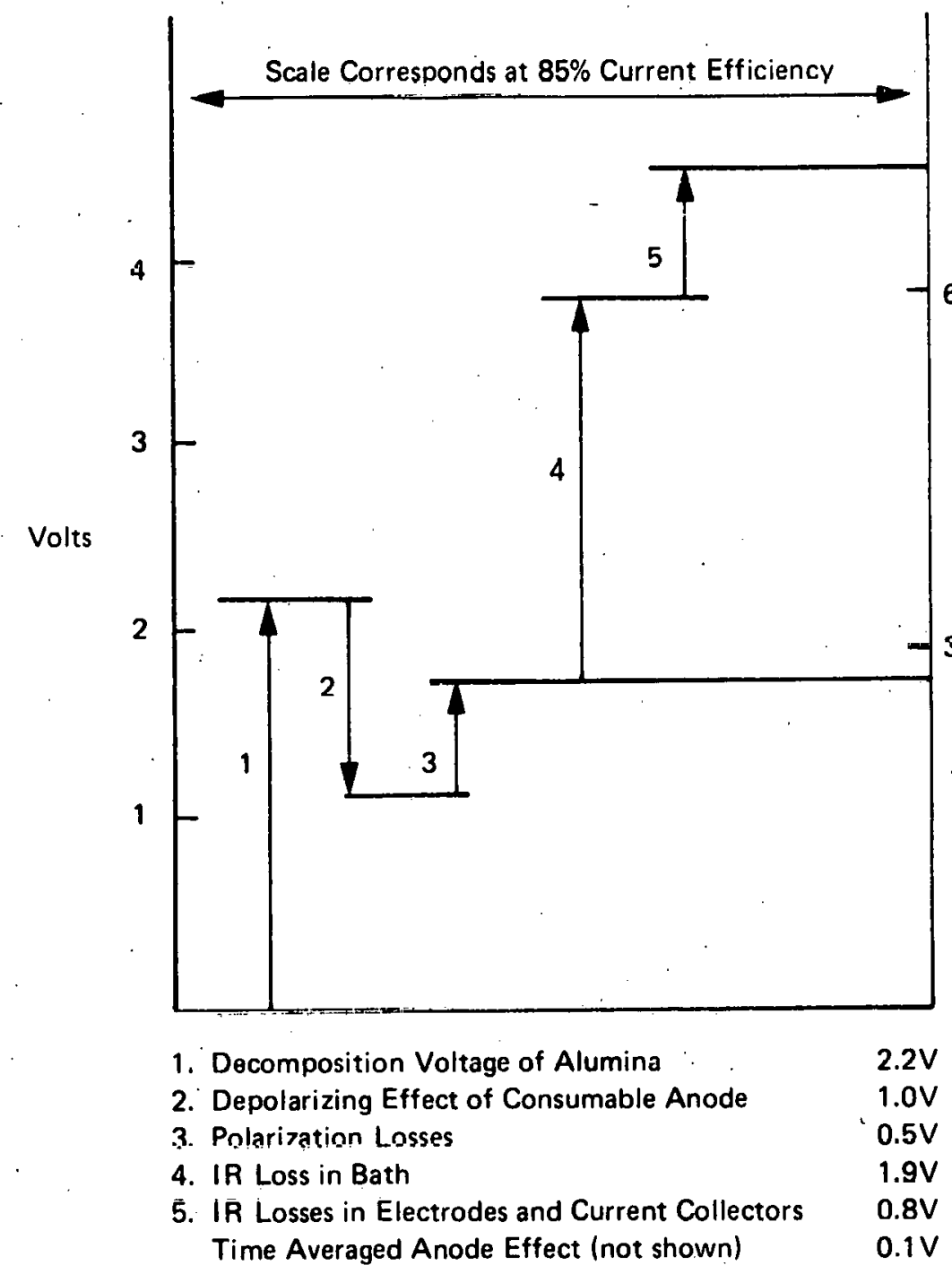

FIGURE III-6 VOLTAGE LOSSES IN HALL-HEROULT CELL 
The other factor to be considered in energy consumption is current efficiency. A back reaction is possible between molten aluminum and the carbon dioxide generated at the anode. That is:

$$
2 \mathrm{Al}+3 \mathrm{CO}_{2} \rightarrow \mathrm{Al}_{2} \mathrm{O}_{3}+3 \mathrm{CO}
$$

In all probability, the mechanism for this reaction is contact between a fog of aluminum metal in the electrolyte (generated by the electromagnetic mixing) and bubbles of carbon dioxide coming off the anode. This is obviously affected by the ACD; at a separation of 2 inches, typical current efficiency would be in the 85-90\% range.

\section{b. Improvements to the Hall-Heroult Process}

Hall-Heroult cells currently operate in the range of 50 to 100's of kiloamperes. Large cells are preferred for their better economics, but there is an upper limit to their size defined by the capability to control the magnetically induced surges in the aluminum cathode. Because of these very large currents, it becomes very important to minimize voltage losses in the system. A breakdown of the losses in a typical prebaked anode cell is given in Figure III-6. The largest loss is in the resistance of the electrolyte (1.9 volts). The polarization associated with the electrochemical process is 0.5 volt, since the reversible voltage for the overall reaction is 1.2 volts.

Since the electrolyte composition has been optimized over the years, particularly with the addition of lithium carbonate to improve the conductivity, the primary factor in the control of this source of voltage loss is the anode/cathode distance (ACD). This, in turn, is dependent on the consumption and repositioning of the anode and the depth of the aluminum pad which is drained at intervals. The ACD, therefore, varies continuously, usually between 1.0 and 2.25 inches. It should also be noted that the $A C D$ in a cell is not uniform, though gross variations tend to be self-correcting.

Consideration of the above factors points to two approaches that provide the opportunity to reduce the ACD: (1) eliminate the need to accumulate an aluminum pool cathode; or (2) deploy a non-consumable anode that could be permanently positioned. The energy saving potential is discussed in later sections.

\section{c. New Processes}

The possibility of producing alumina from such domestic alumina-bearing raw materials as alunite, kaolin, and anorthosite clays is of increasing interest. Nitric acid and hydrochloric acid leaching processes have been identified by the U.S. Bureau of Mines as the most economic for producing alumina from domestic clays. Clay chlorination, as in the Toth alumina process and the Alcoa chloride process, also offers an alternative to the Bayer process and appears, hased on the limited information available, to be commercially viable for primary aluminum production.

Alcoa announced its new electrolytic chloride process for aluminum smelting in 1973. The process involves the electrolysis of aluminum chloride from an electrolyte consisting of alkali and alkali-earth chlorides. Alcoa has built a demonstration plant in Palestine, Texas, which currently has an annual capacity of 30,000 short-tons per year. 
The Alcoa chloride process starts with pot feed alumina from the Bayer process. Specifications call for a minimum purity of $99.426 \%$ alumina. This alumina is chlorinated in the presence of carbon to form volatile aluminum chloride. This, in turn, is purified and fed to the electrolytic cells to produce molten aluminum at the cathode and chlorine at the anode. The chlorine is recycled to the chlorination system. The Alcoa chloride process is shown schematically in Figure III.7. The advantages of this process over the existing Hall oxide electrolysis appear to be:

- Because the decomposition voltage and the bath resistivity are both lower for the chloride melt, the electrical energy requirement is sharply reduced.

- Because oxygen is eliminated from the system, it is not necessary to fabricate and replace the consumable carbon anodes. Permanent graph. ite electrodes can be used, and the expensive energy-consuming anode baking facilities are eliminated.

- Because electrodes can now be permanently emplaced, it is possible to design chluride process cells with multiple sheet electrodes stacked one above another (the so-called "multipolar" electrode configuration). One cell then becomes the equivalent of several single cells, with consequent savings afforded by the much more cumpact cell design.

- Because no cryolite or fluoride materials are used in the chloride process, fluoride emissions are completely avoided.

- The chloride cell operating temperature is about $1292^{\circ} \mathrm{F}$ rather than the $1742^{\circ}-1832^{\circ} \mathrm{F}$ temperature of the Hall process.

\section{Direct Carbothermic Reduction of Alumina to Form Aluminum-Silicon Alloys}

\section{a. Description}

Direct reduction of alumina in a blast furnace-type reactor, which precludes the use of electrical energy (and the inefficiencies of electric power generation), has long been the goal of researchers in aluminum extractive metallurgy. In addition, such a development could effect a significant decrease in capital costs. The problems that have prevented realization of a practical process include:

(1) The high temperatures required for the reduction of alumina - in excess of $3812^{\circ} \mathrm{F}-$ and the complexity of the chemical reactions involved;

(2) The volatility of aluminum and $\mathrm{Al}_{2} \mathrm{O}$ that can be formed at high temperatures and the back reaction of aluminum in the gas phase with carbon monoxide on cooling result in the formation of unacceptable quantities of alumina and aluminum carbide; and

(3) The oxy-carbide liquid phase is viscous and sticky and very difficult to handle. 


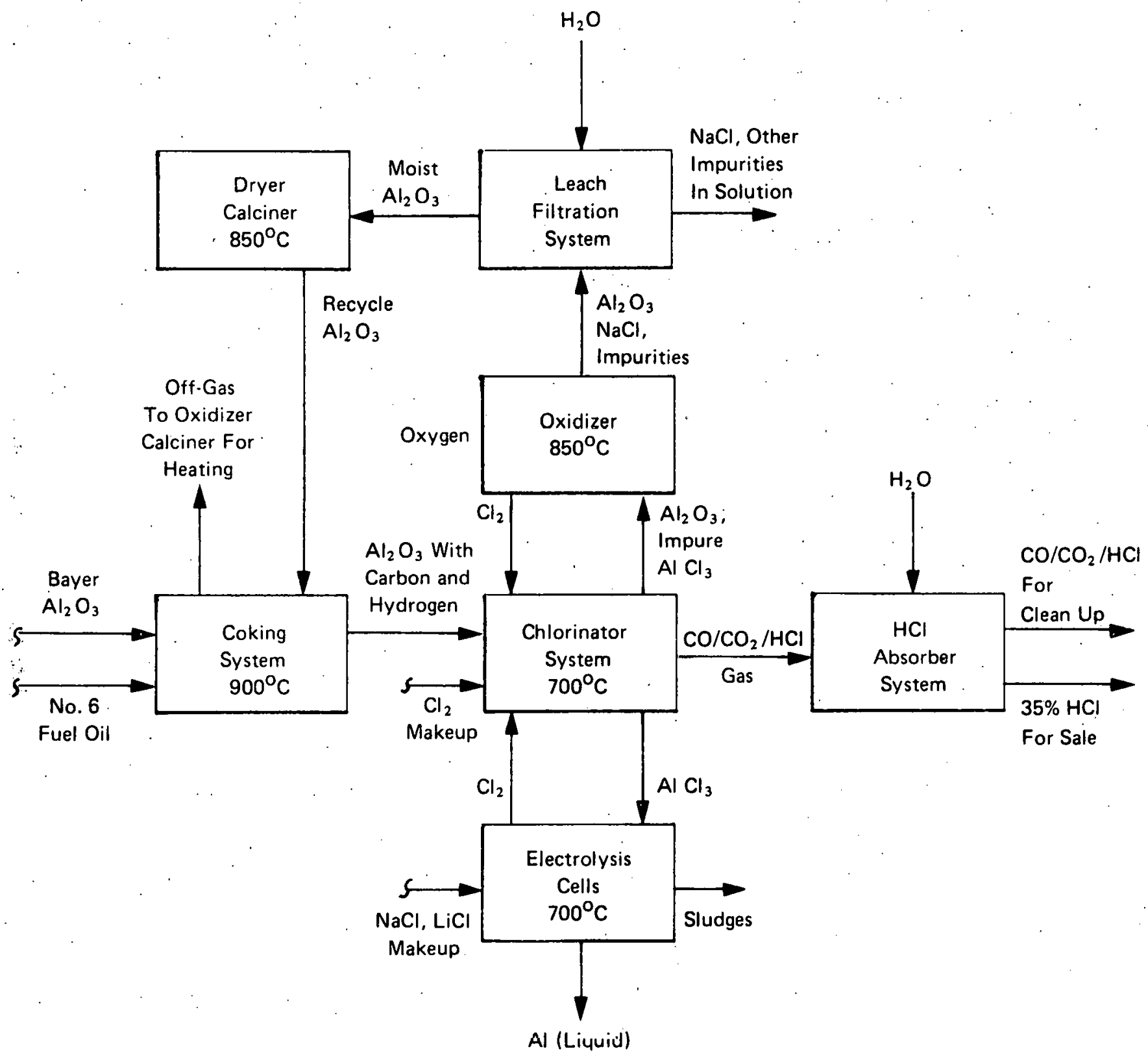

Source: Environmiental Considerations of Selected Energy Conserving Manufacturing Process Options:

Vol. VIII. Alumina/Alumnium Industry Report, U.S. EPA, EPA-60017-76-034h, December 1976.

FIGURE III-7 ALCOA CHLORIDE PROCESS (ASSUMED SCHEME) 
Practical approaches described in the literature are exclusively electric-arc or plasma furnaces with sealed operations to maintain good thermal efficiency. Vapor losses are minimized by condensation of the gas phase.

However, despite efforts by many researchers over most of this century, carbothermic smelting to produce pure aluminum has never been a commercial process. Projects were abandoned because of low yields, high process temperatures, material problems, and control difficulties.

Carbothermic reduction of alumina/silica mixtures is somewhat more straightforward than the reduction of alumina. The problem of low yields is partially overcome by producing aluminum-silicon alloys rather than pure aluminum. The lowered activitice of metal decrease the partial pressures of melal and suboxide vapor. In addition, the reduction of silica to silicon carbide takes place at $2912^{\circ} \mathrm{F}$, a temperature considerably below that at which $\mathrm{Al}_{4} \mathrm{C}_{3}$ can be formed $\left(3632^{\circ} \mathrm{F}\right)$. The aluminum-silicon alloy is formed by a sequence of reactions, such as:

$$
\begin{aligned}
& 3 \mathrm{SiO}_{2}+9 \mathrm{C} \rightarrow 3 \mathrm{SiC}+6 \mathrm{CO} \\
& 2 \mathrm{Al}_{2} \mathrm{O}_{3}+3 \mathrm{C} \rightarrow \mathrm{Al}_{4} \mathrm{O}_{4} \mathrm{C}+2 \mathrm{CO}, \text { and } \\
& \mathrm{Al}_{4} \mathrm{O}_{4} \mathrm{C}+3 \mathrm{SiC} \rightarrow 4 \mathrm{Al}+3 \mathrm{Si}+4 \mathrm{CO}
\end{aligned}
$$

As the reaction temperatures are lowered, there is less loss due to vaporization.

The ratio of aluminum to silicon in the feed material is of obvious importance and should be close to two parts alumina to three parts silica. In practice, this ratio may be achieved by blending the ores, though this is not necessarily a convenient and economic method of operation. It is also essential that the carbon content of the melt be close to the stoichiometric requirement. If there is too little, there will be unreacted alumina, while any excess will remain in the alloy phase or produce solid carbon.

\section{Potential for Eriergy Baving}

Energy requirements for the direct reduction to aluminum-silicon alloy are about 150 million Btu per ton of aluminum in the alloy based on:

- Use of 4.51 tons of coke having an embodied energy of about 140 to 145 million Btu. (About 1.33 tons of coke per ton of alloy would be needed for the reduction of alumina and silica to produce $\mathrm{CO}$ and the alloy. The rest of the carbon is oxidized with oxygen to form $\mathrm{CO}$ and $\mathrm{CO}_{2}$ in order to provide the endothermic heat of: reaction.)

- Use of oxygen (rather than air) having an embodied energy of $35-40$ million Btu.

- By-product CO credit of ahout 30 million Btu.

Energy consumption needs to be experimentally confirmed. Compared to the HallHeroult process consuming 208 million Btu per ton of aluminum, the energy saving potential of the direct reduction process is about 58 million Btu per ton of aluminum. 


\section{c. Present Status of Development}

Selected patents for the direct reduction of aluminum to produce aluminumsilicon alloys are listed in Table III-9. Alcoa is conducting a four-year program, supported by the Department of Energy, to demonstrate the technical feasibility of a pilot-sized direct reduction process for producing aluminum and aluminum-silicon alloys. The three principal steps are: (1) reduction to produce impure aluminumsilicon alloy; (2) alloy purification to commercial Al-Si alloy; and (3) purification to commercial-grade aluminum.

Computer modelling of the reduction reactions, performed by Alcoa predicting aluminum recoveries and the carbon rate to meet process energy requirements - with revisions of data for $\mathrm{Al}_{4} \mathrm{O}_{4} \mathrm{C}, \mathrm{Al}_{2} \mathrm{O}$, and the activities of aluminum and silicon indicated that the process would not be feasible at a pressure of 1 atmosphere, unless some of the energy requirement were supplied electrically. The equilibrium was sensitive to vapor pressure of $\mathrm{Al}, \mathrm{Al}_{2} \mathrm{O}$, and $\mathrm{SiO}$, due to the large amounts of $\mathrm{CO}$ generated by combustion heating. The equilibrium model indicated that - under certain conditions of elevated pressure and temperature - oxygen preheat and dilution of the alloy might make the process feasible. Arc and hybrid blast-arc processes are being considered as an alternative to the combustion-heated process.

\section{d. $R \& D$ Needs and Developmental Costs}

Because there is a large potential market for aluminum-silicon casting alloys, this concept is extremely attractive as an energy saver. Studies on the technical and economic aspects of an arc or hybrid/arc should be fully explored. We estimated developmental costs to be in the range of $\$ 50-200$ million.

\section{e. Role of the Federal Government}

Because of the inherent technical risks involved in the development of a new process and energy conservation potential, we feel that development of this concept may be hampered by lack of R\&D funds. Thus, it would be appropriate for the Federal Government to consider demonstration of its technical feasibility on a pilot scale.

\section{Improved Anodes in Aluminum Reduction}

\section{a. Description}

In aluminum reduction, the carbon anode is consumed to form carbon dioxide and, to a lesser extent, carbon monoxide, according to the reaction:

$$
\mathrm{Al}_{2} \mathrm{O}_{3}+3 / 2 \mathrm{C} \rightarrow 2 \mathrm{Al}+3 / 2 \mathrm{CO}_{2} \text {. }
$$

Oxidation of the anode has a number of disadvantages. To obtain aluminum of acceptable purity, a relatively pure coke with a relatively low ash content has to be used as anode carbon. Prebaked carbon anodes have to be advanced from time to time to maintain optimum anode/cathode distance. Periodically, the prebaked anodes have to be replaced by new material. Also, a separate anode plant is required. Soderberg anodes have to be repeatedly charged with new material. 


\section{SELECTED PATENTS - DIRECT REDUCTION OF ALUMINUM TO PRODUCT ALUMINUM-SILICON ALLOYS}

\section{Patent Number}

U.S. Patent 3,25, 1977, June 21, 1966: Schmidt assigned to Reynolds

U.S. Patents 3661561 , 3661 662, Mav 0, 1972: Trey, Hutchinson, Seth, Lanier, assigned to Ethyl Corporation

U.S. Patent 3,758,289, September 11, 1973: Wood, assigned to Ethyl Corporation

U.S. Patents 1016658 , Septcmber 6, 1977 and 4053 303, October 11, 1977: Cochran, Das Milito, assigned to Aloon.

\section{Description}

This patent describes a method for producing an aluminum-silicon alloy in conformity with the principles described in text, but with the additional feature of adding iron or titanium. The formation of intermetallic compounds in the liquid phase reduces the evaporation of aluminum and gives rise to a melt that is relatively easy to handle. On cooling, the intermetallic compound and elemental silicon crystallize out and can be separated by centrifugation. A $12 \%$ silicon in aluminum alloy is the final product. The yield of the alloy can be increased by processing the solids from the centrifugation process. The patent rovers the stoichiometry of the process in close detail, but therc is no indication of its practice on a large scale. We estimate electrical energy requirements to be in excess of $12 \mathrm{kWh} / \mathrm{lb}$.

These patents describe a blast furnace operation for the reduction of aluminumsilicon ores. The blast furnace is divided vertically into two zones, one containing only carbon; the other, the ore and carbon. By blowing the carbon side with oxygen, carbon monoxide is generated at a sufficiently high tempera. ture to effect reduction in the second zone. There is no evidence of testing as a large-scale process.

A two-step reduction is claimed in this patent; an initial reduction with a fossil fuel, in which temperatures of $1500-1800^{\circ} \mathrm{C}\left(2172-3272^{\circ} \mathrm{F}\right)$ are reached, is followed by electric arc reduction at $2000-2300^{\circ} \mathrm{C}\left(3632-4172^{\circ} \mathrm{F}\right)$. This appears to be a useful dual approach with the merit of reduced electrical energy consumption, together with good stoichiometric control. However, the main energy requirement is for the endothermic reduction process (four times greater that lhe preheat) that is an electrlcal energy demand. Again, there is no evidence of large-scale practice. We estimate the electrical energy requirement to be at least $6 \mathrm{kWh} / \mathrm{lb}$.

These patents also describe ranges of chemical composition arid stoichlometples for reduetion to an alumiriumasilicun alloy. The important difference, howevere, is that the reactions are driven thermally by the combustion of excess carbon with oxygen. To avoid excessive losses associated with the vaporization of aluminum at the higher temperatures, the overall reaction is carried out in stages:

$$
\begin{aligned}
& 3 \mathrm{SiO}_{2}+9 \mathrm{C} \rightarrow 3 \mathrm{SiC}+6 \mathrm{CO} \text { at } 1500-1600^{\circ} \mathrm{C}\left(2732-2912^{\circ} \mathrm{F}\right) \\
& 2 \mathrm{Al}_{2} \mathrm{O}_{3}+3 \mathrm{C} \Rightarrow \mathrm{Al}_{4} \mathrm{O}_{4} \mathrm{C}+\mathrm{CO} \text { at } 1600-190^{\circ} \mathrm{C}\left(2912-3452^{\circ} \mathrm{H}\right) \\
& \mathrm{Al}_{4} \mathrm{O}_{4} \mathrm{C}+3 \mathrm{SiC} \rightarrow 4 \mathrm{Al}+\mathrm{Si}+4 \mathrm{CO}
\end{aligned}
$$

Approximately two-thirds of the iedclive Lal bun munuxide and a significant . amount of the combustion carbon monoxide is removed from the system before there is any production of aluminum metal. Control of feed rates of ore and carbon are critical if proper stoichiometry is to be maintained. 
Theoretically 0.334 pound of carbon is needed to produce 1 pound of aluminum. In practice, however, up to 0.5 pound of carbon is consumed per pound of aluminum. Dusting losses occur because interstitial carbon from the binder is more reactive and is preferentially attacked. Research has also been aimed at finding alternatives to petroleum coke.

As the carbon anode manufacture and utilization is laborious and expensive, attempts have been made to develop inert anodes in which the direct decomposition of alumina to its elements occurs:

$$
\mathrm{Al}_{2} \mathrm{O}_{3} \rightarrow 2 \mathrm{Al}+3 / 2 \mathrm{O}_{2}
$$

Thus, with an inert anode, oxygen is evolved at the anode and can be collected and purified, especially if the cell is sealed. It can therefore also reduce problems relating to pollution of the environment.

To he suitable, an inert anode must have the following properties.

- It must be thermally stable up to $1832^{\circ} \mathrm{F}$.

- The specific electrical resistivity must be very small, so that the voltage drop at the anode is minimal. At $1832^{\circ} \mathrm{F}$, the specific resistivity should be comparable with or less than that of anode carbon. The specific resistivity should be as independent of temperature as possible, so that the voltage drop in the anode remains as constant as possible even when temperature changes occur in its path.

- It must be resistant to oxidation and insoluble in a fluoride or oxide melt.

- It should be adequately resistant to thermal shock.

- Anode corrosion should be negligibly small. The corrosion product should not affect the electrolyte, separated metal or power output.

- The anode must be stable in contact with liquid aluminum, suspended in the electrolyte, and not have an effect on aluminum purity.

- It must be possible to connect the anode with the external electrical system in a stable way at reasonable cost and reasonable voltage drop.

\section{b. Potential for Energy Savings}

With inert anodes, the anodic reaction is oxygen evolution rather than carbon oxidation. This means that the theoretical open-circuit voltage is 2.21 volts as opposed to 1.17 volts with carbon anodes. However, because of polarization effects, the actual difference in voltage is about 0.5 volt, i.e.; oxygen evolution is more rapid than the diffusion-controlled oxidation of carbon. Hence, in order not to increase the power consumption, it is necessary to reduce the anode/cathode distance. We estimate that there may be an overall improvement in efficiency of $8-10 \%$, if a suitable material is found. A major source of energy saving is the elimination of anode consumption, and that energy saving is associated with the elimination of carbon anode baking. 
The energy saving arising from eliminating the consumption of anode carbon of 0.5 ton per ton aluminum, based on an energy value of anode carbon of 49 million Btu per ton of anode carbon (Battelle, 1975), is 24.5 million Btu per ton of aluminum. Although it is not likely that permanent anodes would be considered for retrofit on existing cells, based on aluminum production of 5 million tons, in 1979 if all plants were to retrofit inert anodes on their reduction cell, a potential saving of 0.12 quad/yr would be possible. In our assessment of energy saving, we have assumed that the anode/cathode distance could be decreased sufficiently so that there would be no increase in electrical energy savings. Because of the geometric configuration of the anode-flat or round-it should be possible to decrease the anode/cathode distance to some extent, especially if this has not been achieved by the use of dimensionally stable cathodes.

\section{c. Present Status of Development.}

The only open literature on this topic is in the form of patents in which there are claims for the utility of the following materials as inert anodes:

- Tin oxide, iron oxide, chromium oxide, cobalt oxide, nickel oxide, or zinc oxide with small additions of $\mathrm{Fe}, \mathrm{Sb}, \mathrm{Mr}, \mathrm{Nb}, \mathrm{Zn}, \mathrm{Cr}, \mathrm{Co}, \mathrm{W}, \mathrm{Cd}, \mathrm{Zr}, \mathrm{Ta}$, In, $\mathrm{Ni}, \mathrm{Cu}, \mathrm{Ba}$, or $\mathrm{Bi}$.

- Spinels with the general formula $X Y Y^{1} O_{\text {, where }} \mathrm{X}$ is a divalent or tetravalent metal, and $Y$ and $\mathrm{Y}^{1}$ may be the same or different and are trivalent or divalent metals.

- Perovskite oxides with the general formula $\mathrm{RMO}_{3}$, where $\mathrm{R}$ is a monovalent, divalent, or trivalent metal, and $M$ is a pentavalent, tetravalent, or trivalent metal.

It is claimcd that certain of these materials are stable in a cryolite melt containing dissolved alumina in an clectrolytic eell, as long us the cell is under load. There is a rcquirement fut unifurm current density ànd tor oxygen to contact all exposed surfaces of the anode. In addition, a means of handling oxygen gas at $1000^{\circ} \mathrm{C}$ would have to be devised. Large-scale tests are reputed to have been conducted in Europe, and it is generally considered that, although major problems have been encountered, research work is continuing in this area.

\section{d. R\&D Needs and Development Costs}

Probably the biggest incentive for developing a permanent anode is the opportunity to design a bipolar cell. Progress towards a permanent anode depends on a better understanding of the processes occurring at the anode. We estimate that a developmental program would cost about $\$ 20$ million and require about five years.

One other facet in the development of a permanent anode would be the opportunity to reduce cell voltage by the use of a depolarizing gas. If, for cxample, carbon monoxide were fed to the anode, the theoretical open-circuit voltage would be lowered to 1.29 volts. The concept has been demonstrated in bench-scale work, but the complexity of a large-scale cell and difficulty in maintaining a three-phase interface (electrode-gas-electrolyte) would probably exclude $\mathrm{CO}$ depolarization from practical 
use. Carbon monoxide could conceivably be used as the depolarizer if the anode were an oxygen anion conductor. The known oxygen ion conductors, such as doped zirconia, are unstable in cryolite and cannot support very large currents. Suggestions that hydrogen or methane might be used as depolarizers for a permanent anode are less likely to be practical, because of extensive hydrogen fluoride production.

\section{e. Role of the Federal Government}

Because of the technical risks involved relating to the fairly stringent conditions placed on the anode material, it is appropriate for the Federal Government to consider supporting an inert anode development program.

\section{Improved Cathodes in Aluminum Reduction}

\section{a. Description}

The goal of this project is to develop a long-life cathode that can withstand the environment inside a conventional Hall-Heroult reduction cell, while allowing smaller anode-cathode spacing. The major problem with carbon cathodes is that the molten aluminum does not wet the carbon. At the high current densities present in today's cells, the pad of aluminum tends to have ripples and waves in its surface, and these force the operators to maintain a thick layer of electrolyte to prevent shorting of the cell. To accommodate a thick layer of both aluminum and electrolyte in the cells, the spacing between the anode and cathode is usually maintained at 1.5 to 2.2 inches to prevent electrical shorting.

The major improvement inherent in the cathodes made from materials such as titanium diboride is that the new cathodes have a very low electrical resistance and are readily wetted by metallic aluminum. Since the metallic aluminum readily spreads over the entire cathode, the operators can drain the metallic aluminum out of the cell as fast as it is produced, while maintaining a cathode wetted with aluminum. The thin film of aluminum present on the cathode does not ripple at present current densities or even at higher current densities. The operator can sufely run the mechanism with a much thinner layer of electrolye by reducing the anode/cathode spacing from 1.0 to 0.5 inch or less. This would result in a subetantial energy saving of 20 to $25 \%$ in aluminum smelting due primarily to the lower electrical resistance drop across the electrolyte and better current efficiency.

The performance goal is a 3-year life for the improved cathode when in contact with molten aluminum and electrolyte at $1724^{\circ}-1787^{\circ} \mathrm{F}$. Many of the cathodes fabricated to date tend to be very brittle and develop stress cracks during operation. The project is designed to demonstrate a long-lived, commercially viable cathode system.

\section{b. Potential for Eriergy Savings}

Theoretically, $2.85 \mathrm{kWh}$ of energy are required to produce 1 pound of aluminum. In actual practice, carbon cathodes produce a range of 6 to $8.5 \mathrm{kWh}$ per pound of aluminum, with a U.S. average of $7.8 \mathrm{kWh}$ per pound. Most of the energy inefficiency is attributable to electrical resistance through the electrolyte between the anode and 
cathode. With the improved cathodes and decreased anode/cathode spacings, a conservative saving of $20 \%$ in energy use appears achievable. A total of $164 \times 10^{12} \mathrm{Btu}$ 's per year, or 0.164 quad could have been saved in 1979 if all aluminum plants used an improved cathode system.

\section{c. Present Status of Development}

We did not have access to the details of the cell design in the present program, but we understand that both brittleness and stress cracking of the cathodes are still major problems. We know of no successful three-year test within this program, or at any of the other aluminum companies developing their own cathodes. The solution of the life problems with the new cathodes remains a very difficult development problem.

\section{d. $R \& D$ Needs and Development Costs}

Development work started on the improved cathodes for aluminum smelting in the 1950 's. Twenty-flve years later, much progress has been made, but severc problems with cathode life still hinder demnnstration of the technology. We feel that another six years and $\$ 40$ million will be required to bring the technology to the demonstration stage under the most favorable circumstances.

\section{e. Role of the Federal Government}

Because it is a relatively high-risk development project, an appropriate role of the Federal Government may be to reduce the risk and development/demonstration time for this technology. The Federal Government should consider whether there may be advantages to be gained by a joint aluminum company research program.

\section{ALUMINUM MELTING}

\section{Conventional Technology}

In the primary smelting of aluminum, operators periodically siphon off liquid metal from the reduction cells and pour. it into ingot molds to cool and solidify. The aluminum ingots are either sold to another company for further processing or, more frequently, shipped to another site within the company where they are rolled or cast into products. Since most aluminum products are aluminum allnys rontaining emall amounts of nther metals, the operatore at the fabricating plusuls remelt the pure aluminum ingots in reverberatory furnaces and add the appropriate alloying metals, such as magnesium, manganese, copper, zinc, and silicon. The addition of alloying metals results in properties, such as increased strength and toughness and better machining. The reverberatory furnaces used in remelting the ingot are typically fueled wilh either natural gas or distillale vil, since it is important that only clean combustion gases contact the metals.

\section{Use of Coal in Aluminum Melting}

\section{a. Description}

The object of this program is to substitute coal for the hydrocarbon fuel presently burned in the reverberatory furnaces and still have clean combustion gases in the furnace. The program attempts to demonstrate that a coal-fired burner can produce a 
clean combustion gas that is acceptable both to the metal and the environment. Three problem areas exist when one burns coal; (1) the ash; (2) the sulfur content; and (3) fixing of nitrogen to produce nitrogen oxides.

The contractor chose a cyclonic, slagging, two-stage coal combustor developed by the Gencral Electric Company under a U.S. Department of Energy program for closedcycle magneto-hydrodynamics. The unit produces 4.0 million Btu's per hour in clean combustion gases when fired with 350 pounds per hour of pulverized coal. The combus: tor burns the coal in the first stage to release the ash which is heated by the reactions to above the melting point.

The cyclone design of the burner imparts an axial swirl to the gases and throws the molten slag droplets onto the walls where they are trapped. The molten slag on the walls of the burner flow into a sump that collects up to $90 \%$ of the ash in the incoming coal.

To remove the sulfur from the coal (up to $3.5 \%$ of its weight), the operator introduces either powdered limestone, dolomite, sodium carbonate, or potassium carbonate with the coal to react with the sulfur dioxide formed and trap it as a metallic sulfite. In one test, the addition of 14 parts of potassium carbonate per 100 parts of coal resulted in the removal of $99.8 \%$ of the sulfur dioxide. The additives also act as a fluxing agent in the molten slag to ensure that it flows rapidly into the slag trap.

The two-stage combustion system should also reduce the formation of nitrogen oxides, while fostering complete combustion of the coal. In the first stage (run with an air-to-fuel ratio of 0.6 ), the fuel-rich combustion gasifies the coal, while suppressing the formation of nitrogen oxides. In the second stage, additional air completes the combustion and tertiary air quickly cools the flame in the furnace to reduce the formation of nitrogen oxides.

The transfer of the technology developed for magneto-hydrodynamics to this project, if successful, could show the way to wider application of the clean combustion of coal in other applications now requiring gas or oil.

\section{b. Potential for Energy Savings}

If all the primary aluminum were remelted in reverberatory furnaces fired by a pulverized-coal burner, about $29 \times 10^{12}$ Btu's per year of hydrocarbon fuels could be saved. Table III-10 shows the basis used to generate the estimate of energy saving. Even though the amount of energy saving is relatively modest on a national scale, even if one were to additionally include all the reverberatory furnaces in the secondary aluminum industry, the technology could have widespread applicability in many other metallurgical and industrial processes now using hydrocarbon fuels to produce clean combustion gases.

\section{c. Present Status of Development}

The Alcoa Corporation is starting to test the burner rated at 350 pounds of coal per hour on a 7 -foot diameter aluminum ladle furnace. As the program continues, a burner rated at 1000 pounds of coal per hour will fire a 40,000 -pound capacity furnace. 
TABLE III-10

ENERGY SAVING FROM USING COAL IN ALL PRIMARY

ALUMINUM MELTING FURNACES

Heat Required for Warm-up to Melting Point

$5.25 \times 10^{5} \mathrm{Btu} / \mathrm{ton}$

Heat Required for Melting $+3.40 \times 10^{5} \mathrm{Btu} / \mathrm{ton}$

Total Heat in Molten Metal

$8.65 \times 10^{5} \mathrm{Btu} / \mathrm{ton}$

Fuel Required (15\% efficiency typical of these furnaces)

$5.76 \times 10^{6} \mathrm{Btu} / \mathrm{ton}$

With the 1979 Total Production of 5,015,000 Tons of

Aluminum, Annual Energy Saving (nationally)

$29 \times 10^{12}$ Btu

\section{d. R\&D Needs and Development Costs}

A key item in the development of the burner will center on the life of the rofractory matcrial on the inside of a cyclone burnei. The refrucluries will be exposed to highly corrosive conditions in the presence of molten slags with significant amounts of alkali metals. We do not have any data on the actual performance of the refractories, but a successful, long-term test will be a significant milestone in the project. The project has about four years to go to achieve the demonstration stage. The total development costs and testing could conservatively cost about $\$ 10$ million for all participants.

\section{e. Role of the Federal Government}

The project is still in a developmental stage where the funding of the Federal Government may play a critical role in its completion. In evaluating the project's energy saving potential, one could view it as a test of using coal to produce clean combustion gases in a number of applications that extend far beyond the aluminum industry.

\section{BIBLIOGRAPHY}

The Aluminum Association, Inc., "Aluminum Industry Energy Conservation Workshop Papers," Energy Conservation Workshop, May 26-27, 1976.

The Aluminum Association, Inc., "Aluminum Industry Energy Conservation Workshop Papers," Energy Conservation Workshop, February 7-8, 1978.

Arthur D. Little, Inc., "Environmental Considerations of Selected Energy Conserving Manufacturing Process Options," Volume III, Alumina/Aluminum Industry Report, U.S. Environmental Protection Agency, EPA-600/7-76-034h, December 1976.

Arthur D. Little, Inc., "A Survey of Potential Processes for the Manufacture of Aluminum," Argonne National Laboratory, ANL/OEPM-79-4, December 1979.

The Aluminum Association, Inc., "Energy and the Aluminum Industry," April 1980. 


\section{OTHER HIGH-TEMPERATURE INDUSTRIES}

\section{A. COPPER}

\section{Background}

The United States is the leading producer and consumer of copper in the world. In 1979, the United States produced 1.6 million tons of primary copper. Based on 95 million Btu per ton of cathode copper (University of Utah, 1980), the energy consumption for the copper industry is approximately 0.15 quad.

Refined copper is produced from primary sources, i.e., originating from mined ore or from secondary sources (scrap). Most copper is consumed as refined metal. In 1978, about $71 \%$ of the refined copper was consumed by wire mills and most of the remaining $29 \%$ by brass mills. Refined copper is marketed in regular or standard shapes consisting largely of wire bars, cathodes, ingots and ingot bars, cakes, slab and billets. The principal end-uses are in building construction, electrical and electronic products, industrial machinery equipment, transportation, and consumer products. In addition, copper scrap is used to make brass and bronze ingots that are consumed principally by foundries.

The primary sector consists principally of 12 firms. Several leading copperproducing companies are integrated and have mining, smelting, refining, and fabricating facilities, as well as marketing organizations. Other large producers mine and process through the smelting or refining stage, while still other companies mine and process their ore and ship the concentrate to custom plants for smelting and refining. Copper smelting capacity in the United States in 1978 totaled approximately 9.0 million tons of charge, estimated to represent 2.0 million tons of smelter product. Refinery capacity totaled 2.9 million tons, approximately 88 percent of which was electrolytic refining and electrowinning capacity and 12 percent was fire-refining (including Lake copper) capacity.

In the secondary copper smelting and refining industry, the plants fall into two fairly distinct segments: (1) producers of either brass and bronze ingots; and (2) producers of unalloyed copper. Most of the firms in the secondary copper industry are small, individually owned operations having a single plant; only a few are publicly held. A minority of the firms (but still representing a large fraction of the production) are either subsidiary operations of large mining companies or subsidiaries of conglomerates. The four largest companies account for about $40 \%$ of the value of shipments; eight companies about $70 \%$; and the 20 largest, for about $85 \%$ of the value of shipments.

There are about 60 plants in the brass and bronze ingot segment and about half a dozen producers of unalloyed copper, which may be in the form of blister copper, firerefined copper, cathode copper, wire bar, continuous cast, or a finished product, depending on both the production scheme and the needs of the customer. Also, several precious metals are usually recovered as a result of electrorefining to produce cathode copper. 
This section is based on data compiled in a DOE study (conducted by Arthur D. Little, Inc., and other subcontractors, University of Utah, 1980). It dealt with energy use for proven and new copper processes.

\section{Conventional Technology}

Ores of copper are classified as sulfide, native copper, or oxide. Of these, sulfide porphyry deposits account for about $90 \%$ of the U.S. production, most of the world output, and most of the estimated commercial copper reserves of the world.

\section{a. Pyrometallurgy}

After mining, sulfide ores are primarily treated by crushing, grinding, and froth flotation to produce a concentrate of sulfide minerals.

The extraction of copper from sulfide ores is conveniently divided into four segments:

- Mining - Ore containing 0.4 to $2 \%$ copper is blasted and excavated;

- Beneficiation - Copper minerals are crushed, ground, and separated. from the gangue materials to produce a concentrate containing about $25 \%$ to $30 \%$ copper.

- Smelting - Concentrates are smelted and reacted to produce anode copper containing $98 \%$ to $99 \%$ copper; and

- Electrorefining - The anode copper is refined to produce more than 99.9\% pure cathode copper.

\section{b. Hydrometallurgy}

In contrast, many oxide ores are not amenable to concentration and are treated with dilute sulfuric acid to dissolve the copper. Hydrometallurgical approaches involve leaching the ores to bring copper values into solution and solution purification, followed by electrowinning or a chemical reduction step.

\section{Assessment of Energy Consumption}

\section{a. Mining and Concentration}

Today open-pit mining is extended to depths of as much as 1,500 feet below the rim. The energy use and dollar cost of hauling rock from such depths become limiting factors in determining the life of the surface mining operation. Energy use should be clearly distinguished from dollar cost optimization. Wach strategy will result in a different cutoff grade. There is an increasing bias relative to energy optimization as its availability is constrained as its unit cost goes up, as mining proceeds to ores of lower grade, and as environmental protection regulations increase. The cutoff grade significantly affects the tonnage of the orc going to the mill and the tomnage going lu dump leaching. On the basis of an average mill feed grade of $0.55 \%$ copper and a cutoff grade of $0.29 \%$ copper, energy use in mining is listed in Table IV-1. 
TABLE IV-1

\section{ENERGY USE IN MINING FOR A STRIPPING RATIO OF 1.25}

$\begin{array}{lcc}\text { Unit } & \begin{array}{c}\text { Million Btu's } \\ \text { Per Ton Cathode } \\ \text { Copper }\end{array} & \begin{array}{c}\text { Percent } \\ \text { Total Mining } \\ \text { Energy }\end{array} \\ \text { Drilling } & 0.612 & 3.0 \\ \text { Blasting } & 3.895 & 19.4 \\ \text { Loading } & 1.849 & 9.2 \\ \text { Hauling } & 13.137 & 65.2 \\ \text { Ancillary } & 0.638 & 3.2 \\ \text { Total } & \underline{20.131} & 100.0\end{array}$

Source: Arthur D. Little, Inc., 1980.

The analysis of Table IV-1 is presented in terms of energy per ton of cathode copper produced (Level $1^{*}$ and Level $2^{* *}$ energy requirements) and is based upon a copper recovery of $87.5 \%$ in concentration and $98.7 \%$ by conventional smelting. A sensitivity analysis indicates that increasing cutoff grade decreases the energy per normalized ton of cathode copper charged to mining operations, while that charged to milling increases. The resulting counteractive energy values produce a small net energy difference in the overall energy requirements, although a minimum is indicated at the cutoff value of $0.4 \%$ copper.

The increased recovery of copper from dump leaching as the cutoff grade increases does not markedly decrease the average energy use per ton of cathode copper produced. This insensitivity results from the high energy use in current dump leaching practice. Conversely, the energy use per net ton of cathode copper produced is very sensitive to the stripping ratio and pit depth.

In the energy analysis, certain areas in which further research may be fruilful isi the context of energy conservation, relative to mining were highlighted. These are:

- Rock haulage,

- Explosive utilization, and

- Optimization of the cutoff grade, taking into account the trade-off between conventional concentration and dump leaching.

Energy use in milling is very sensitive to the mining cutoff grade when normalized in terms of the cathode copper produced. The approximate energy use per net ton of ore is 0.156 million Btu's, $60 \%$ of which is in the grinding step. On the basis of an

-Level 1 represents direct fuel requirements; l.e., natural gas, fuel oll, electricity, etc.

" Level 2 includes Level 1 energy use, plus the energy requirement for consumables used in the process. 
average copper recovery of $87.5 \%$ in concentration and $98.7 \%$ in conventional smelting.

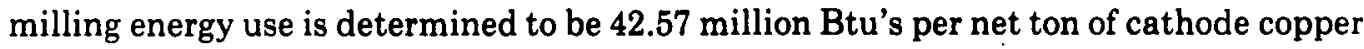
produced from a mill head ore grade of $0.55 \%$ copper.

It appears that any major improvement in energy use in milling will require optimized energy use in grinding. This conceivably may be achieved by the application of stabilizing control strategies in the grinding operation itself and in related operations, such as flotation and classification. This analysis points to a potential energy savings in the use of autogenous and semi-autogenous mills for certain copper sulfide ores. Also pebble mills may be an attractive option for grinding when viewed in terms of energy optimization.

\section{b. Pyrometallurgical Technology}

Table IV-2 lists the energy use (Level 2) evaluated for several commercial and proposed pyrometallurgical processes. The range of values for each category are also listed. The mining and milling values may be adjusted relative to conventional smelting with a recovery of $98.7 \%$.

TABLE IV-2

\section{ENERGY USE IN COPPER PYROMETALLURGY TECHNOLOGY FOR SMELTING AND REFINING (million Btu per ton cathode copper)}

\begin{tabular}{llll} 
Category & \multicolumn{1}{c}{ Process } & & Range \\
Ulder & Conventional Smelting (Green Charge) & 35.16 & \\
Proven & Conventional Smelting (Calcine Charge) & 30.92 & $30-44$ \\
Processes & Electric Furnace Smelting & 42.97 & \\
& Outok.umpu Flach Smclting & 18.92 & $19-21$ \\
& INCO Flash Smelting & 21.25 & \\
Newer & Noranda Continuous Smelting & 24.00 & \\
Proven & Mitsubishi Continuous Smelting and Converting & 19.76 & $20-29$ \\
Processes & Oxy-Fuel Reverberatory Smelting & 28.62 & \\
& & & \\
New & Top Blown Rotary Converter Smelting & 23.56 & \\
Unproven & Queneau-Schuhmann Continuous Smelting & 22.63 & \\
Processes & Oxygen Sprinkle Smelting & 22.4 & \\
& AMAX Dead Roast Blast rurnace Smelting & $19.58+1.5^{*}$ & \\
& Scgrcgntinn Prociss & 21.03 & \\
& Thermo-Electron Chlorination Process & 20.20 &
\end{tabular}

To obtain the total energy required for producing a ton of cathode copper, the energy for mining and concentrator operations must be added. For a $98.7 \%$ recovery in the smelting operation the estimated mining energy is 20:13 and concentrator energy is $\mathbf{4 2 . 5 7}$ million Btu/ton cathode copper.

"Value reported by AMAX for electro-refining is approximately 1.5 million Btu less than value used for other processes in this study; also, the energy requirement for fugitive emissions control is not included. 
It is important to note that the energy-based comparison among processes can be significantly different from an economic comparison between the same processes, since the labor and fixed capital requirements for the processes may vary considerably. Similarly, the processes produce different types of environmental intrusions (fugitive emissions, waste water, slag and sludge) and the costs or future potential cost of dealing with these streams may vary from process to process. What is presented here is a comparative discussion of the processes based on energy consumption alone.

Table IV-2 shows that conventional smelting is energy-intensive. It uses large quantities of hydrocarbon fuels, deriving little energy from the combustion of the sulfides. Hot calcine smelting (roast-reverberatory) practice is less-energy intensive than the green charge practice by approximately 4 million Btu's, mainly resulting from lower fuel and air requirements and the resultant decrease in the volume of offgas which must be handled. The oxy-fuel (Caletones) process at about 29 million Btu's shows considerable improvement over conventional smelting. More important, while sulfur recovery as acid in conventional smelting is below $70 \%$; sulfur recovery in Caletones oxy-fuel smelting would be more than $90 \%$.

Electric furnace smelting is the most energy-intensive of all the pyrometallurgical processes analyzed in this study. The addition of fluid bed roasting could reduce the fuel requirements by approximately 3 million Btu's per ton of cathode copper.

It is evident (see Table IV-2) that two of the proven processes based on matte smelting, Outokumpu flash smelting and INCO flash smelting, fall in the lowest range of energy consumption (19-21 million Btu's per net ton of cathode copper produced). This is a significant improvement over conventional smelting and illustrates the important conclusion that, with the many technological improvements incorporated in these processes over the last 30 years, there has been a significant improvement in energy efficiency. Newer proven processes (based on matte smelting) fall in the midrange of energy consumption (19-29 million Btu's per net ton of cathode copper produced). These are the Mitsubishi, Noranda and oxy-fuel processes. Of these, the Mitsubishi and Noranda processes are at the lower end of the range and are close in energy consumption to the flash smelting processes. It should be noted that improved reactor design, in general, also makes these processes more environmentally acceptable. This is particularly true for developments which reduce converter aisletype operations in a process, reducing fugitive emissions.

Six processes are newer, unproven processes and fall into two categories. Three of these processes are based upon matte smelting. They are TBRC, Q-S, and oxygen sprinkle smelting. These three processes fall in the same energy range (20-24 million Btu's per net ton of cathode copper produced) as other newer processes based on matte smelting. Three processes, not based on matte smelting are the AMAX dead roast blast furnace, segregation, and Thermo Electron Corp. processes. These processes similarly show relatively low energy usage.

The AMAX dead roast blast furnace process and the segregation process, have been tested only on a pilot plant basis, but not on a commercial scale. The segregation process has been tested on a commcrcial scalc for rcfractory eilioate ores, but not on 
roasted calcines. It is difficult to analyze the Thermo Electron Corp. process comparatively, since background data are incomplete and are based on bench-scale tests only.

Evolutionary development of pyrometallurgical processes employing matte smelting chemistry may be viewed in terms of two major developments beyond conventional reverberatory smelting; namely, flash smelting and continuous processing. In the future, energy saving features, improved environmental acceptability; minimal loss of copper in the slag, large capacity, fugitive emission control and design features minimizing heat loss must receive special attention. The conventional reverberatory-Pierce Smith process is clearly obsolete. Flash furnace technology, now over 30 years old, and well proven, may be viewed as a modern, transition-proven technology, while Mitsubishi and Noranda are modern continuous-proven processes. It is difficult to asseess whether or not these latter two are transitional.

Mitsubishi uses three smelting steps and, while it is offective in oonoorving on fugitive emission energy requirements, it deviates from a single reactor concept. The Noranda process is too new to assess from this point. of view. It is continuous, but elag cleaning appears to be a problem. Oxygen sprinkle smelting by these criteria may be viewed as transitional, unproven, representing a potentially significant linking between older and newer technologics.

The TBRC is difficult to analyze in the same framework as the other processes mentioned, except it must be considered at this point as somewhat unproven for the large-scale smelting of copper. It is limited in size, operates best on high-grade mattes, and has the added capability of fire refining. The Q-S processes, as designed, is capable of going from copper feed to blister copper and falls in the category of modern and continuous-unproven processes. A similar version, the QSL (Queneau-ShuhmannLurgi) process for lead is now at the demonstration stage by Bundes Minesterium Súr Forsching und Technologie in Germany. The demonstration plant (250 tpd galena) is funded at a level of $\$ 25$ million U.S., one-half by German industry and one-half by the German government with tests to be completed by the end of 1982 .

It appears that the reactor of the future, with a production capacity of 100,000 tons per year, will most likely be a single continuous reactor capable of minimizing convective and radiative heat loss, fugitive emissions, and effective in removal of impurities. Such a single reactor should meet the following conditions:

- Produce blister copper low in impurities;

- Produce a clean slág;

- Increase $\mathrm{SO}_{2}$ concuntration and minimizze gas volume;

- Fully utilize the fuel energy in the copper-iron sulfide feed; and

- Provide close control over emissions.

For smaller operations, e.g., 25,000 tons per year, other options appearly likely, e.g., the TBRC may be well suited to plants of this size as may be several hydrometallurgical processes. 


\section{c. Hydrometallurgical Technology}

Table IV-3 lists the Level 2 energy requirements for eight selected hydrometallurgical processes. Energy usage for in situ solution mining is also included. The hydrometallurgical processes are grouped according to three ranges of energy (Level 1 and Level 2) required. The total energy values, including mining plus beneficiation, are also listed in Table IV-3. The table clearly shows that hydrometallurgical processes, in general, are more energy-intensive than smelting. This comes mainly from high use of embodied energy in consumably and ineffective use of the heat of reaction. The processes having lowest Level 2 components, viz., roast-leach-electrowin, Cymet ferric chloride leach, electroslurry and sulfite reduction, are notably less energy-intensive and, in terms of energy, are comparable with conventional or electric furnace smelting.

\section{TABLE IV-3}

\section{ENERGY USE IN COPPER HYDROMETALLURGICAL TECHNOLOGY \\ (million Btu per ton cathode copper)}

\section{Concentrate to Refined Copper}

Process

Roast Leach Electrowin *

Cymet Ferric Chloride Leach

Roast/Sulfite Reduction

Electroslurry-Envirotech

$U$ of U/MM Ferric Sulfate

Acid Leach

Sherritt Cominco

Arbiter Ammonia Leach *

Nitric-Sulfuric Acid Leach

In-Situ Solution Mining

\section{Range}

30.45

30.92

23.64

39.63

49.45

48.13

62.05

74.44

51.60
Range

(Mining to Refined Copper)

\footnotetext{
"Process which have been used commercially. To obtain the total energy required for producing a ton of cathode copper, the energy for mining and concentrator operations must be added. For 98.7 percent recovery in the smelting operation, the estimated mining energy is 20.13 and the concentrator energy is $42.5 /$ milion Btu's per ton of cathode copper.
}

All of these processes, with the exception of the Cymet ferric chloride leach and the sulfite reduction process, employ electrowinning for metal reduction. Improvement in electrowinning thus presents an area for reduction in the overall energy use in these processes. Chemical reductants used in the Cymet and sulfite reduction processes are clearly less energy-intensive than conventional electrowinning. The Envirotech electroslurry cell appears to be operable with approximately 25 to $30 \%$ less energy than conventional electrowinning. 
Combination processes, using both pyrometallurgical and hydrometallurgical steps, are generally less energy-intensive than all-hydrometallurgical processes. The combination processes are roast-leach-electrowin, Cymet ferric chloride, SherrittCominco, and sulfite reduction.

The all-hydrometallurgical processes, in general, are the most energy-intensive. These are the Arbiter ammonia leach, the nitric-sulfuric acid leach, and the ferric sulfate leach. The electroslurry modification of the ferric sulfate leach is less energyintensive than the University of Utah/Martin Marietta version based on electrowinning, because of the lower cell voltage of the electroslurry electrowinning step. The Arbiter ammonia leach is less energy-intensive than the nitric-sulfuric acid process, resulting principally from the high heat of reaction, since sulfide sulfur is oxidized all the way to sulfate. Improvements in the nitric-sulfuric acid and Arbiter processes require a more effective recovery of waste heat.

In general, the high-energy requirement for hydrometallurgical processes results from electrowinning, inefficient use of reaction heat; high process steam requirements, and extensive use of consumable materials. It does appear that significant improvements can be made in energy usage by more effective waste heat recovery, new electrowinning technology, and the combination of alternative lower energy unit processes.

The smelting-electrorefining processes recover byproducts such as precious metals, selenium, and tellurium in the form of anode slimes. This stream of slimes is small, about 5 to 25 pounds per ton of cathode. The slimes are treated by a combination of processes to recover these byproducts. Technology for the recovery of such byproducts from the hydrometallurgical processes is not so well developed. Furthermore, it involves the handling and treatment of much higher volumes of solid residues (iron oxides and/or jarosites), about 3 to 6 tons per ton of cathode. This treatment is likely to entail more energy consumption than the anode slimes treatment. An exception of this is the Sherritt-Cominco process which produces only 0.7 ton of solid residue per ton of cathode copper, thus enhancing precious metals recovery. In addition, this process can recover the associated metal values such as molybdenum and zinc.

One of the major apparent benefits of hydrometallurgical processing is the absence of significant emissions to the air from process units. In pyrometallurgical processing, on the other hand, the control of emissions is expensive in both energy and economic terms. This has to be weighed against the increased potential for water pollution. In this analysis, we allowed for a significant amount of energy for the control of fugitive emissions in pyrometallurgy (about 4 million Btu's per ton of cathode). In spite of this, there is a significant difference in energy consumption between the two types of processes, generally in favor of pyrometallurgy.

Of all the processes proposed, roast/sulfite reduction has the greatest potential for competing with smelting processes in terms of energy usage. However, the process is unproven. Also, effective recovery of heat from the roasting step by an auxiliary heat exchange system seems capable of reducing the reported values appreciably for both the roast leach and sulfite reduction processes. 
The construction of hydrometallurgical process plants capable of producing 100,000 tons of copper per year seems unlikely, at least in the next decade. Application to smaller tonnages is more likely, i.e., less than 25,000 tons per year of finished copper. The hydrometallurgical process most likely to succeed in the future will have to be designed to recover process heat in a useful form and will require vastly improved electrowinning technology or use chemical reductants.

\section{In Situ Solution Mining}

The in situ extraction of copper from a deep-seated deposit appears to be the least energy-consuming process of all the extraction procedures investigated in spite of only $50 \%$ overall recovery assumed for this technique. The major energy saving factors are reduced energy involved in mining, the elimination of the concentration step, and more effective use of intrinsic heats of reaction under autoclave conditions in place. The estimated energy requirements (Level 2) of about 80 million Btu's per ton of cathode copper are at least 15 to $20 \%$ lower than the pyrometallurgical processes considered and about 25 to $75 \%$. lower than the hydrometallurgical techniques investigated.

The energy requirements are based on an assumption that only $50 \%$ of the copper is recoverable in this process. If higher recoveries are achievable, then the in situ extraction would be even more attractive for recovering copper from deep-seated deposits. On the other hand, the in situ technique is not a proven process, and experimental work is needed to demonstrate that the $50 \%$ recovery is possible. It should also be noted that such techniques would be applicable only where the geological structure permits containment of the pregnant solution.

\section{Potential Energy Conservation Process/Concepts}

A variety of evolutionary and new energy saving ideas which have significant potential for decreasing the energy consumed in copper production have been identified. These ideas generally relate to unit operations which could be utilized by many of the processes discussed in this report. However, in all cases, additional research and evaluation are necessary to verify this potential for energy saving. These ideas are presented helow with a short discussion of their significance.

\section{a. Mining/Dump Leaching}

Mining energy represents about $21 \%$ of the energy consumed in copper production. If the down-stream processes are not efficient and do not recover most of the contained copper, the contribution of mining energy toward the production of cathode copper would greatly increase. The areas that warrant further research and evaluation in mining are:

- Alternatives for ore and waste haulage, e.g., the use of belt conveyors versus trucks in mines;

- The trade-off between the use of more blasting agents for additional breakage in the mine versus primary and secondary crushing; and

- Optimization of cut-off grade to define the trade-off between energy consumption in dump leaching versus cut-off grade. 
It was found that dump leaching is more energy-intensive than commonly realized (University of Utah, 1980). Areas that warrant further research are:

- Fundamentals of dump leaching; and

- Improvements in aeration and rate of copper extraction in dump leaching.

\section{b. Grinding/Concentration}

Grinding and concentration consume about $45 \%$ of the energy used in the production of cathode copper, with grinding being the major energy consumer. Since their introduction during the last part of the 19th Century, tumbling mills have proven to be superior to other grinding equipment for a very wide variety of applications. However, they are still quite inefficient in that no more than $1.2 \%$ of the energy consumed is used for the creation of new surface. Because of the large quantity of energy consumed in tumbling mills, even a small improvement could have a significant impact on energy conservation. The areas that warrant further research and evaluation (which would generally benefit all industries using tumbling mills) are.

- The use of pebble milling in copper ore grinding where pebbles of hard rock, such as quartzite, are substituted for ore (autogenous) or steel grinding media;

- Research on stabilizing control strategies in grinding, classification, and flotation;

- Evaluation of optimal energy consumption in size reduction by trade-offs between blasting, crushing, grinding, and regrinding;

- Development of techniques for more efficient classification to prevent the unnecessary recycling of fines to the grinding mill; and

- Evaluation of alternative grinding devices such as attrition mills whichmight have higher arinding efficioncies.

\section{c. Pyrometallurgy}

Pyrometallurgical processes are most effective when the following conditions are met:

- Exothermic heat of reaction is used to melt the charge materials;

- Discontinuous batch processing is minimized;

- The heat content of the off-gases is recovered in waste heat boilers;

- An optimum degree of oxygen enrichment is used;

- The process produces strong sulfur dioxide-containing streams suitable for sulfuric acid manufacture;

- The throwaway slag is low in copper; and

- The process results in minimal emissions of fugitives to the working environment. 
The areas that warrant potential research/evalution are:

- The use of waste heat recovered from hot off-gases to dry and preheat. concentrates. At present, most or all of the newer smelting processes use an external source of fuel for this purpose. An energy saving of $5-10 \%$ is conceivable by effective waste heat recovery.

- The pyrometallurgical slag-cleaning processes could be improved to reduce the copper content of the throwaway slags and increase the copper recovery. Energy consumption is sensitive to increased recovery since mining and concentration energy could be proportionately decreased for a given production. A $1 \%$ increase in recovery amounts to approximately a 1 to 2 million Btu savings in energy because of the high mining and concentration energy values. Since the slag is available to such processing in the molten state, the procedure requires conditions which will maximize the reduction and separation of the copper. It should be noted that the Q-S process best addresses these questions conceptually.

- Continuous one-step smelting processes are energy-efficient as compared to the two-step processes because of better utilization of heats of reaction. In addition, a hot-matte transport step and the attendant heat loss and fugitive emissions are eliminated. Several of the new generation of pyrometallurgical processes can be operated in continuous one-step fashion. However, the potential for transfer of arsenic, antimony, and bismuth to the metallic copper phase in such processes requires special design criteria. Current electrorefining technology is generally inadequate for handling significant levels of these impurities in anode copper. Therefore, research on unit operations which would remove these impurities from blister copper prior to electrorefining in a single continuous reactor would be very desirable. The successful implementation of this research would lead to true one-step smelting of copper concentrates and may result in a saving of $10-20 \%$ of the energy used in smelting. Potential approaches would include slagging and/or vaporization of the impurities. Future research for a large capacity copper smelting process for optimizing energy usage, environmental control and metal loss should be centered around the development of a single continuous reactor.

- The flue dusts collected in pyrometallurgical processing are rich in volatile impurities such as arsenic, zinc, and lead. Because of the high copper content (more than 5\%), these dusts are generally recycled. However, when impurity concentrations reach such levels that this recycling has a deleterious effect on copper quality, then the dusts have to be stockpiled or discarded. This reduces copper recovery and represents a significant energy loss. Appropriate processes for flue dust treatment would preclude this loss and also effect the recovery of valuable byproducts.

- Steam recovered from waste heat in smelters is used to generate electric power to drive the blowers in the acid plant and for converter air. If the smelter had an adjoining electrolytic refinery, the low-level steam, after 
going through a topping steam turbine cycle, could be used for electrolyte heating. A detailed assessment of utility requirements in a smelter/refinery complex is necessary to quantify the potential for energy saving using this approach.

\section{d. Hydrometallurgy}

While hydrometallurgical processes show a higher level of energy consumption than pyrometallurgical processes, they are at an early stage of development and, therefore, offer considerable potential for improvement. The areas that warrant research and evaluation are:

- Research to decrease energy consumption in electrowinning is important since electrowinning consumes $21-24$ million Btu's per ton of cathode copper, or almost $20 \%$ of the total. This energy could be reduced by a direct approach to increase the efficiency of elestrnwinning by loworing overpotentials and by investigating alternative anode reactions. Another approuch would be to find an alternative use of electric energy for reduction (which incorporates the inefficiencies in electric power generation) and use, instead, other reductants such as hydrogen, sulfur dioxide, and other reducing gases or coal-based reductants.

- Research is desirable to optimize the transfer of heat from the exothermic leaching reactions to the reactants more effectively. This would involve major modifications in reactor design.

- Research in hydrometallurgy process development most likely should move toward processes which pretreat the chalcopyrite feed to provide a more euitablo feod matcrial, and which either avoid electrowinning by using chemical reductants or use some totally new, low-energy electro. winning/refining step.

- It may be possible to geneiale electrical energy whlle recovering copper by treating copper concentrates in a slurry electrode/fuel cell configuration. Research in this area has the potential for energy saving in the future.

\section{In Situ Solution Mining}

While all of the research ideas discussed earlier would increase conventional reserves by reducing energy requirements and costs, in situ solution mining is unique in that it adds low-grade deep-seated deposits (which cannot be exploited economically by conventional technology) to the reserves of available copper.

A multi-faceted R\&D program would be desirable to optimize the overall extraction of copper by in situ leaching techniques, including a demonstration phase under field operating conditions to improve the technique to obtain higher recoveries than the $50 \%$ recovery assumed in this study. Specifically, such a program would include work on:

- Actual oxygen or air consumption related to the type and extent of mineralization; 
- Application of recent developments in blasting stressed rock with flooded joints;

- Weathering and leaching characteristics of copper porphyry ores under an extended period of ore-solution contact;

- Quantification of lixiviant reactions with copper contained in host rock; and

- Modelling and simulation for optimization.

\section{Potential For Energy Conservation}

The energy saving potential of the research ideas presented in Section IVA-5 is not uniform. Table IV.4 shows estimates of this energy saving potential in terms of millions of Btu's per ton of cathode copper in the first numerical column. Since the United States produces about 2 million tons of copper from primary sources, the total potential for energy savings in the United States would be approximately 2 million times these numbers if one assumes that each technique was successfully adapted to primary copper production. The actual saving that could be realized would vary considerably. For example, improvements in mining and milling would be potentially applicable to the production of other ores and minerals or mineral products, such as cement. On the other hand, some of the techniques (e.g., flue dust treatment) are probably necessary only for a fraction of the concentrates used in primary copper production.

The second column shows the estimated probability of success in each area. The probabilities are designated "very high" and "high" if the approach has already been demonstrated in some fashion and requires technology transfer. The probability is designated "medium" if the direction of research and development is reasonably well defined, but requires further work. Finally, the probability is designated "low" if the direction of research is not fully defined.

The third column shows our assessment of the R\&D cost implications. The fourth column characterizes each idea in terms of its potential for retrofit into existing plants versus its applicability to new grassroots plants. This is an indication of the rate at which these ideas may be adopted, if successful. The last column shows the type of research necessary before the techniques will be adopted by industry.

Finally, it is important to address concepts not included in the specific recommendations as stated, or listed in Table IV-4. Any process should be considered from the origin of the ore (mining) to the finished product as a total system. In this context significant energy conservation may result by matching individual steps to optimized energy conservation. Matching ore chemical and physical characteristics, minor and major impurities, and potential for byproduct recovery with the process steps selected may have significant energy conservation implications. 
TABLE IV-4

\section{CHARACTERIZATION OF RESEARCH IDEAS}

\section{Potential \\ Energy Savings (MMBtu/Ton)}

\author{
Probability \\ of \\ Success ${ }^{2}$
}

R\&D Cost

Implication ${ }^{3}$
Range of

Applicability
Type of

Research $^{3}$

\section{Mining}

Haulage vs. trucks

Blasting vs. crushing/grinding

Concentration vs. dump leaching

Fundamentals of dump leaching

Increase aeration and copper extrastinn

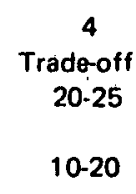

deoff

20-25

$10-20$

$V H^{*}$
$H$
$H$
$M$

$M^{\prime}$

\section{1}

$1-2$

1

$2 \cdot 3$
S,D

$S, D$

S,D

L,P,D

Grinding

Pebble mill autogeneous

Stabilizing control

Optimal onorgy oontrol

New classification techniques

Other milling devices

$43 \quad M$

\section{2}

2-3

$1-2$

$\begin{array}{ccc}0.7 & H & 1 \\ 2 & M & 3 \\ 2 & M & 3 \\ 1 & \text { L } & 2-3 \\ 4-5 & V H^{*} & 1 \\ 4-7 & H & 3-4\end{array}$

$\begin{aligned} \text { R,G } & \text { S } \\ \text { R,G } & \text { S,L,P,D } \\ \text { R,G } & \text { S,L,P,D } \\ \text { R } & \text { S,L,P,D } \\ \text { R } & \text { S } \\ \text { G } & \text { P,D }\end{aligned}$

Hydrometallurgy

\section{Electrowinning}

Use of alternate reduction schemes

Reactor design for optimum heat transfer

In Situ Mining

8

15

3

2D
L 3

$\mathrm{H} \quad 3$

H $\quad 1-2$

M
$S, L$

$S_{i} L$

L,P

"Where applicable.

1. NA - Not available for "blue sky" type of ideas.

2. VH - Very high - approach has been demonstrated successfully elsewhere in the industry. $\mathrm{H}$ - High - approach based on technology transfer but not demonstrated.

$M$ - Medium - direction of research is known; needs further work.

$\mathrm{L}$ - Low - direction of research not fully defined.

3. $\$ 0.1$ Million $=1 ; \$ 1$ Million $=2 ; \$ 10$ Million $=3 ; \$ 100$ Million $=4$.

4. $A=$ Retrotit; $G=$ Grassroots.

5. $L=$ Laboratory; $P=$ Pilot plant $D=$ Demonstration; $S=$ Study. 
Examples are:

- Trade off between explosives and primary crushing in the open pit;

- Bulk flotation followed by grinding and selective flotation;

- Concentrate pretreatment before smelting or hydrometallurgical processing; and

- Merging of hydrometallurgical and pyrometallurgical steps.

\section{BIBLIOGRAPHY}

Battelle Columbus Laboratories, "Energy .Use Patterns in Metallurgical and Nonmetallic Mineral Processing - Phase IV - Energy Data and Flowsheets, High Priority Commodities," PB 245 759, June 1975.

Battelle Columbus Laboratories, "Energy Use Patterns in Metallurgical and Nonmetallic Mineral Processing - Phase V - Energy Data and Flowsheets, Intermediate Priority Commodities," PB 246 357/AS, 1975.

Gordian Associates, "The Potential for Energy Conservation in Nine Selected Industries-The Data Base," Volume IV, Copper, 1975.

Arthur D. Little, Inc., Industrial Environmental Research Laboratory, "Environmental Considerations of Selected Energy-conserving Manufacturing Process Options." Vol. XIV, Primary Copper Industry Report, U.S. Environmental Protection Agency, Report No. EPA 600/7-76-034n, December 1976.

Kellogg, H.H., "Energy Consumption in New Copper Extraction Processes," J. Metals, August 1974, pp. 21-23.

Kellogg, H.H. "Sizing Up the Energy Requirements for Producing Primary Materials," Engineering and Mining Journal, April 1977, pp. 61-65.

.Kellogg, H.H., and J.M. Henderson, "Energy Use in Sulfide Smelting of Copper," Extractive Metallurgy of Copper, Vol. I, American Institute of Mining, Metallurgical and Petroleum Engineers, p. 378, 1976.

University of Utah, "An Assessment of Energy Requirements in New Copper Processes," Draft Report to the Department of Energy, February 1980. 


\section{B. MAGNESIUM}

\section{Background}

Although magnesium is the third most abundant element in the earth's crust and is available in almost limitless amounts from seawater as well as from such land-based sources as magnesite, dolomite, and $\mathrm{MgCl}_{2}$-containing brines, it has not achieved more than a modest use. Annual production of magnesium is only about one-thirtieth that of aluminum for which it is a natural substitute. While magnesium has some shortcomings, such as susceptibility to corrosion and low tensile strength, a major impediment to its increased use is its relatively high cost compared with aluminum; also there is a limited number of producers of magnesium. A substantial part of the high cost is the very large energy consumption per unit weight of product. The energy consumption (per net ton) for magnesium is $50 \%$ higher than for aluminum.

During 1979, U.S. production of primary magnesium was 160,000 tons. There are four companies that produce magnesium in the United States. Three companies produce magnesium electrolytically and ono by oilicothermic proccos. Dow Chcmicals in Freeport, Texas, uses seawater as raw material. American Magnesium in Snyder, Texas uses well brines, and N-L Industries in Rowley, Utah (now bought out by Amax) uses Great Salt Lake brines. Northwest Alloys, a subsidiary of Alcoa, uses the Magnatherm process. We estimate the annual capacities of U.S. magnesium producers as follows; Dow Chemicals, 130,000 tons; American Magnesium, 6,000 tons; N-L Industries (Amax), 24,000 tons; and Northwest Alloys, 24,000 tons.

\section{Conventional Technologies}

The principal technologies used in the production of magnesium include:

- Fused salt electrolysis of magnesium chloride from sea water and brines, e.g., Dow, IFG; and

- Metallothermic reduction of $\mathrm{MgO}$ derived from land-based sources, principally magnesite and dolomite, e.g., the Pidgeon and Magnatherm processes.

\section{a. Magnesium Metal from Seawater}

Seawater is the major raw material source for the domestic production of magnesium. Brines of the Great Salt Lake in Utah represent a minor source. In the production of magnesium from seawater (see Figure IV-1), magnesium hydroxide is formed by mixing seawater with calcined dolomite. After filtration, the magnesium hydroxide is reacted with hydrochloric acid to produce magnesium chloride which is then dried and fed to electrolytic cells. The chlorine that evolves is converted to hydrochloric acid for reuse. Figure IV-1 indicates the flowsheet for the production of magnesium from seawater.

Table IV-5 summariżes the energy requirements for producing magnesium ingot from seawater (Battelle, 1975). These represent Level 2 estimates for energy use, i.e., in addition to direct energy use such as natural gas, fuel oil, electricity, coal, and coke, the energy content of consumables is also included. 


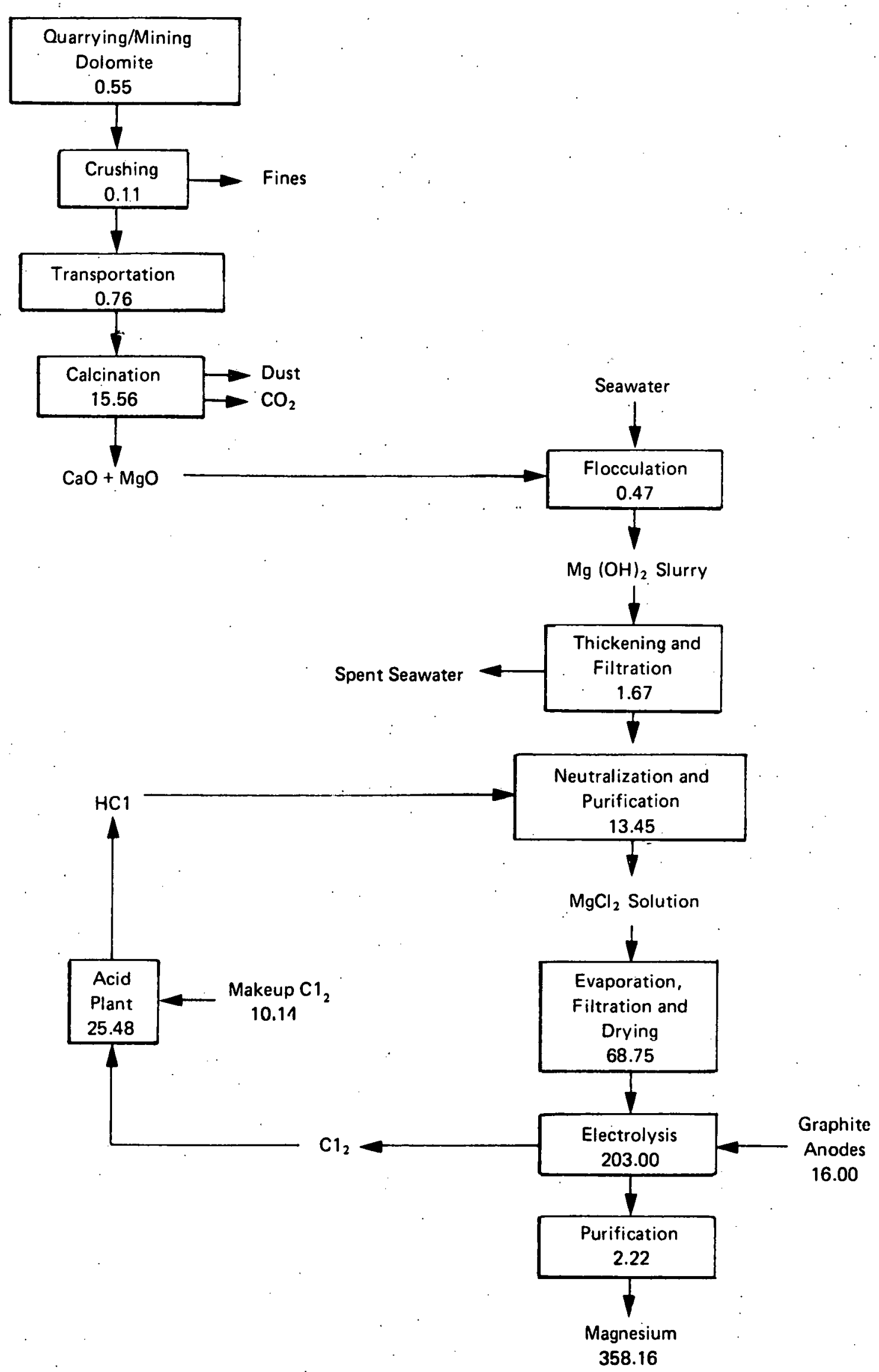

Note: Number's are $10^{6}$ Btu/ton Mg. 
PRODUCTION OF MAGNESIUM METAL FROM SEAWATER

\begin{tabular}{|c|c|c|c|c|}
\hline$\therefore$ & Unit & $\begin{array}{l}\text { Units per } \\
\text { Net Ton of } \\
\text { Magnesium } \\
\text { Metal }\end{array}$ & $\begin{array}{l}10^{6} \text { Btu's } \\
\text { per Unit }\end{array}$ & $\begin{array}{c}10^{6} \text { Btu's per } \\
\text { Net Ton of } \\
\text { Magnesium } \\
\text { Metal }\end{array}$ \\
\hline \multicolumn{5}{|l|}{ Quarrying dolomite } \\
\hline Diesel fuel oil & gal & 1.78 & 0.139 & 0.25 \\
\hline Other fuels & Btu & -- & - & 0.13 \\
\hline Electrical energy & kWh & 3.48 & 0.0105 & 0.04 \\
\hline Explosives & lb & 4.34 & $\begin{array}{c}0.03 \\
\text { Subtotal }\end{array}$ & $\frac{0.13}{0.55}$ \\
\hline \multicolumn{5}{|l|}{ Crushing } \\
\hline \multicolumn{5}{|l|}{ Transportation } \\
\hline Rail (estimated 150 miles) & net ton-mile & $1,140.0$ & 0.00067 & 0.76 \\
\hline \multicolumn{5}{|l|}{ Calcining } \\
\hline Clectrical enteryy & $k W h$ & 13,8 & 0.0105 & 0.75 \\
\hline \multirow[t]{2}{*}{ Natural gas } & $\mathrm{cu} f \mathrm{t}$ & $14,790.0$ & 0.001 & 14.79 \\
\hline & & & Subtotal & 15.56 \\
\hline \multicolumn{5}{|l|}{ Flocculating } \\
\hline Electrical energy & kWh & 44.4 & 0.0105 & 0.47 \\
\hline \multicolumn{5}{|l|}{ Settling and filtering } \\
\hline Electrical energy & kWh & 158.6 & 0.0105 & 1.67 \\
\hline \multicolumn{5}{|l|}{ Neutralizing and purifying } \\
\hline Electrical energy & $k W h$ & $121: 0$ & 0.0105 & $1: 27$ \\
\hline Natural gas & $\mathrm{cuft}$ & $12,180.0$ & $\begin{array}{r}0.001 \\
\text { Subtotal }\end{array}$ & $\frac{12.18}{13.45}$ \\
\hline \multicolumn{5}{|l|}{$\begin{array}{l}\text { Evaporating, filtering, } \\
\text { and drying }\end{array}$} \\
\hline Electrical energy & $k \hat{W h}$ & 171.0 & 0.0105 & 1,79 \\
\hline Natural gas & cu $\mathrm{ft}$ & $66,960.0$ & $\begin{array}{r}0.001 \\
\text { Subtotal }\end{array}$ & $\frac{66.96}{68.75}$ \\
\hline \multicolumn{5}{|l|}{ Electrolysis } \\
\hline Electrical energy & kWh & $17,109.0$ & 0.0105 & 179.64 \\
\hline Natural gas & cu ft & $23,360.0$ & 0.001 & 23.36 \\
\hline Graphite electrodes & net ton & $0.1^{2}$ & 160.0 & $\frac{16.00}{31000}$ \\
\hline \multicolumn{5}{|l|}{ Acid Plant } \\
\hline Electrical energy & kWh & $1,334.0$ & 0.0105 & 14.01 \\
\hline Notural gas & $\mathrm{cull}$ & $11,170.0$ & 0.001 & 11.47 \\
\hline \multirow[t]{2}{*}{ Makeup chlorine } & net ton & 0.49 & 20.7 & 10.14 \\
\hline & & & Subtotal & 35.62 \\
\hline \multicolumn{5}{|l|}{ Magnesium purification } \\
\hline Electrical ènergy & kWh & 51.3 & 0.0105 & 0,54 \\
\hline Natural gas & cu ft & $1,680.0$ & 0.001 & 1.68 \\
\hline & & & Subtotal & 2.22 \\
\hline & & & Total & 358.16 \\
\hline
\end{tabular}

Source: Battelle, 1975. 
The principal electrolytic technologies available are from Dow, Norsk Hydro and the U.S.S.R.

\section{b. Metallothermic Reduction}

Commercially practiced processes involving ferrosilicon reduction of magnesium oxide include: (1) the Pidgeon process and (2) the Magnatherm process.

(1) Pidgeon Process - The Pidgeon silicothermic process involves the reduction of magnesium oxide by silicon:

$$
2 \mathrm{MgO}+2 \mathrm{CaO}+\mathrm{Si}=2 \mathrm{Mg}+\mathrm{Ca}_{2} \mathrm{SiO}_{4} .
$$

The raw materials for the reaction, which is carried out in a retort, are dolomic limestone, reduced to oxide by elimination of carbon dioxide in a rotary kiln, and ferrosilicon, obtained in an electric furnace reduction of silica by carbon in presence of iron. Calcined dolomite contains more than $20 \%$ magnesium and the ferrosilicon grades used vary from $65-85 \%$ ferrosilicon.

The finely ground raw materials are mixed and compacted into hard, dense briquettes to enable intimate contact of particles and to increase charge weight for a fixed retort volume. The charge is distributed through the length of a horizontal tube (retort) with an 11 -inch bore diameter and 10 feet long; the tube is located within the hot zone of a gas or electrically heated furnace. The vapor is condensed by cooling a steel sleeve in the extended, water-cooled section of the retort. This process is practiced at Haley, Ontario, by Chromasco, Ltd.

(2) Magnatherm Process - The Magnatherm process involves the use of ferrosilicon to reduce magnesia in an oxide slag to magnesium vapor. Calcined dolomite and ferrosilicon are charged to an electric furnace where heat is generated by passing current through a resistive slag. The reaction is conducted at high temperatures $\left(2822^{\circ} \mathrm{F}\right)$ and low pressures $(0.05 \mathrm{~atm})$. The magnesium gas is condensed to magnesium liquid in a cooler part of the furnace.

Alumina is charged to the furnace to lower the melting point and viscosity of the slag. The process is conducted in a batch mode with the vacuum broken twice each cycle of 20-24 hours. At the first break (minor downtime), only slag is tapped; at the second break (major downtime), both slag and metal are tapped. The magnesium is melted, fluxed, and poured into ingot molds.

\section{Potential Energy-conserving Processes/Concepts}

In 1979, U.S. production of magnesium was 160,000 short tons. Based on energy consumption of 358.2 million Btu's ton of magnesium ingot, the national energy consumption for primary magnesium production was approximately $57 \times 10^{12}$ Btu's per year. If one assumes that the energy consumption can be reduced by $30 \%$, then the energy-conserving potential of improved production methods for primary magnesium production approximates 17 trillion Btu's on the basis of a $100 \%$ market penetration. 
The other aspect of energy conservation is the energy saving attributable to decreased fuel usage in automobiles arising from the use of light-weight components. Based on a 100,000 mile vehicle life and accounting for both direct and indirect weight savings, the following net life-cycle energy credits in gallons of gasoline per pound of weight saving in substitution of a cast iron part in automotive applications have been estimated: magnesium, 5.5; aluminum, 3.2; and HSLA steel, 0.4 (Kenney, et al., 1980). Life-cycle energy use comparisons should be made on a part by part basis.

The following is a listing of energy-conserving processes and concepts relating to the production of primary magnesium.

\section{a. Electrolytic Technology}

- Use of fluid bed calciners in place of rotary kilns or shelf dryers;

- Solar evaporation of magnesium chloride solution;

- Use of hot gases from electric generating gas turbines to spray dry magnesium chloride solutions;

- Use of hot gases from the spray dryers to preheat the feed to spray dryers;

- Improved cell design:

- Increase thermal efficiency by reducing $I^{2} R$ losses;

- Closer anode/cathode spacing;

- Larger cell-bipolar cell technology can provide significant improvement in the space/time yield of a magnesium electrolytic cell, impacting energy use and reducing operating costs;

- Recovery of the energy in converting $\mathrm{Cl}_{2}$ to $\mathrm{HCl}$; and

- High-purity magnesium chloride feed. The Nalco Chemical Company has recently announced a new, innovative, organic solvent extraction process for the production of high-quality anhydrous magnesium ohloride.

\section{b. Metallothermic Reduction}

- Operate the ferrosilicon process at higher pressure and make process continuous.

- Lowering energy requirements for ferrosilicon.

Improvements in metallothermic technology have been made. Over the last five years, a $40 \%$ increase in production capacity has been made in the average daily production rate with corresponding reductions in raw material, energy, and labor requirements. The conversion of the current batch metallothermic process to a continuous operation would result in significant improvements in production and operating cost reduction.

\section{c. Carbothermic Reduction}

Carbothermic reduction is desirable from the standpoint that the reductant used in metallothermic processes consumes a significant amount of the energy used in the 
process. Carbon would be a less energy-intensive reducing agent. One of the main problems to successful development of a carbothermic reduction process for magnesium has been the separation of magnesium vapor from carbon monoxide. A suitable quenching technique is needed to prevent reaction of magnesium vapor and carbon monoxide.

\section{d. Energy Conservation through Magnesium Recycling}

Recycling represents an important way of conserving energy. About half of the magnesium used in the United States is used as an alloying element in aluminum. Hence, recycling as much of the contained magnesium as possible is highly desirable. In the past, only about $4 \%$ of the magnesium alloyed to aluminum was recycled, because aluminum-base scrap was predominantly used in diecasting alloys. With the aluminum can recycling programs of the major aluminum companies, a significant effort is being made to recycle all such scrap back into the same product, thus recycling the magnesium.

When aluminum-base scrap is used to make aluminum diecasting alloys, the magnesium content is reduced when necessary by demagging (reacting magnesium with chlorine), and this magnesium is presently not being recovered.

There is approximately a $5 \%$ loss of magnesium when it is alloyed to aluminum. Efforts are underway to improve the situation. Such effort should be pursued and augmented, if necessary.

Recycling of magnesium - in-house scrap (such as runners and gates) - by a diecaster is generally practiced. There is potential for an increase in the amount of old scrap that is recycled. 


\section{BIBLIOGRAPHY}

Barclay, J.A., "Energy Consumption in Primary Magnesium Production," Report from International Conference on Energy Consumption in Production and Utilization of Magnesium, Massachusetts Institute of Technology, May 25-27, 1977.

Battelle Columbus Laboratories, "Energy Use Patterns in Metallurgical and Nonmetallic Mineral Processing - Phase IV - Energy Data and Flowsheets, High Priority Commodities," PB 245 759, June 1975.

Battelle Columbus Laboratories, "Energy Use Patterns in Metallurgical and Nonmetallic Mineral Processing - Phase V - Energy Data and Flowsheets, Intermediate Priority Commodities," PB 246 .357/AS, 1975.

Gordian Associates, "The Potential for Energy Conservation in Nine Selected Industries - The Data Base," Volume IV, Copper, 1975.

Kellogg, H.H., "Sizing Up the Energy Requirements for Producing Primary Materials," Engineering and Mining Journal, April 1977, pp. 61-65.

Kenney, G.B., D.R. Sadsway, and M.C. Flemings, "An Assessment of the Potential for Magnesium Penetration of the U.S. Automotive Market," 37th International Magnesium Association Conference, Salt Lake City, Utah, June 1980. 


\section{PORTLAND CEMENT}

\section{Background}

The Portland cement industry in the United States is made up of 162 operating plants in 40 states (Pit and Quarry, July, 1980). All plants process minerals (usually quarried within a few miles of the plant) to form cement clinker. Many plants also grind the cement clinker into cement. The product is then shipped to the user. Both cement clinker and cement are articles of trade.

This industry is made up of 40 operating companies, many of which own and operate more than one plant. No company operates more than 11 plants (Pit and Quarry, July 1980). Since no company dominates the industry, and since the basic technology is mature and non-proprietary, individual companies do not generally maintain a research facility for development of new techniques for cement manufacture. Instead, the U.S. companies look toward the industry trade association, Portland Cement Association (PCA), equipment vendors, and academic institutions for advances in the state of the art of cement chemistry and/or manufacturing techniques. In fact, much of the new technology is imported from Europe or Japan.

The cement industry is a capital-intensive industry. New plants cost approximately $\$ 80-\$ 125$ per annual ton of product, and plant modernization or expansion costs approximately $\$ 60-\$ 80$ per annual ton of product. In early 1980 , a ton of cement sold for $\$ 46$ (Engineering News Record, May 8, 1980). The industry is slow to retire old plants or replace existing capacity, and is cautious about implementing new technology because of the capital-intensive nature of the industry. A typical cement plant which manufactures ground cement from raw material that it quarries consumes 2.1 trillion Btu's per year of fuel and $66.7 \times 10^{8} \mathrm{kWh}$ of electricity to produce 500,000 tons of cement. The cost of this energy represents approximately $25 \%$ of the cost of the manufacture of cement in 1977 (Annual Survey of Manufactures, 1977).

During the last three decades, new technology has been available which reduces the quantity of energy consumed in the manufacture of cement. Only in the last few years has there been any significant shift toward these technologies.

\section{Conventional Cement Process}

The conventional cement manufacturing process which has been practiced for nearly a century is the reaction of ground $\mathrm{CaCO}_{3}$ with the addition of $\mathrm{Al}_{2} \mathrm{O}_{3}, \mathrm{Fe}_{2} \mathrm{O}_{8}$, and $\mathrm{SiO}_{2}$ in a rotary kiln. As the feed or raw meal is heated, residual moisture is drawn off, the $\mathrm{CaCO}_{3}$ is calcined to $\mathrm{CaO}$ with the liberation $\mathrm{CO}_{2}$, and the finely ground mixture is partially melted. The partially melted material agglomerates into nodules called cement clinker. During the partial melting, the chemistry of the material changes from individual oxides to calcium aluminates, calcium silicates, and calcium ferro aluminates. The clinker drops from the kiln into a clinker cooler which preheats the combustion air for the kiln. The clinker is then mixed with a small amount of gypsum and ground to cement. 
There are two variations of the basic technology which are practiced today - wet and dry processing. In wet processing, the raw materials are wet ground in ball mills and stored as slurries prior to the kiln process. In dry processing, the raw materials are ground dry and stored in hoppers. The wet process requires somewhat less electricity, because wet ball milling is more efficient than dry grinding of the raw materials; however, the wet process uses considerably more kiln fuel than the dry process to dissipate the water. All new capacity is built with dry kilns, unless the raw materials are particularly wet when quarried or purchased.

Two modifications to the dry kiln process which reduce the energy consumption of the kiln have been introduced. Both use a portion of the waste heat from the (linkering to accomplish the processes of preheating or calcining. These technologies, called preheating and precalcining, operate on the raw meal prior to entering the kiln. A typical preheater is a five-stage suspension preheater which consists of five sets of cyclones in series with countercurrent flow of hot waste gases and raw meal from stage to stage. This technology has allowed kiln fuel requirements to drop by $30 \%$.

The second technology, precalcining, first preheats the feed as described above with hot waste gas. In this case, however, the waste gas comes from the calciner and the feed goes into the precalciner from the preheater. To achieve the appropriate temperatures in the precalciner, auxiliary fuel is fired. This technology offers an. additional kiln fuel saving potential of approximately $10 \%$ over a dry kiln with a preheater alone.

A summary of the energy consumption of the various conventional technologies is shown in Table IV-6.

\section{Controlled Particle-size Distribution Cement}

Controlling particle-size distribution - and thus decreasing or eliminating "fines" - is known to reduoo tho olootrioal onorgy roquirod to grind matorialo; thio technique, when used in closed-loop grinding and classification to reduce overgrinding, has been optimized in many industries to reduce energy consumption in grinding. The controlled particle-size distribution study attempts to explain the effects of controlled grinding on grinding energy conservation. A second benefit - and one which the PCA* has demonstrated in the laboratory - is that controlled particle-size distribution cement (CPSD) is a better product with improved characteristics. It is the proof of these improved properties that the PCA seeks since cement, with improved properties, would be required in smaller quantities, per cubic yard of concrete, thereby saving material, money, and energy.

The PCA demonstrated that it could alter the properties of cement and cement paste (cement and water mixture with no sand or aggregate) by controlling the

-Portland Cement Association 
TABLE IV-6

\section{ENERGY CONSUMPTION PROFILE OF CONVENTIONAL TECHNOLOGIES}

\begin{tabular}{|c|c|c|c|c|c|}
\hline & Wet & $\begin{array}{l}\text { Dry } \\
\text { Kiln }\end{array}$ & $\begin{array}{l}\text { Dry with } \\
\text { Preheater }\end{array}$ & $\begin{array}{r}\text { Dry wi } \\
\quad \& P\end{array}$ & $\begin{array}{l}\text { h Preheated } \\
\text { ecalciner }\end{array}$ \\
\hline Slectricity & & \multicolumn{3}{|c|}{ Million Btu's" per Ton of Clinker } & \\
\hline Feed Grinding & 0.40 & 0.53 & 0.53 & & 0.53 \\
\hline Kiln & 0.34 & 0.31 & 0.37 & & 0.37 \\
\hline Clinker Grinding & 0.70 & 0.76 & 0.76 & & 0.76 \\
\hline Fuel & \multicolumn{5}{|c|}{ Million Btu's" per Ton of Clinker } \\
\hline Quarry & 0.34 & 0.34 & 0.34 & & 0.34 \\
\hline Kiln & 5.36 & 4.60 & 3.20 & & 3.00 \\
\hline Total & 7.14 & 6.54 & 5.20 & & 5.00 \\
\hline
\end{tabular}

particle-size distribution of the ground cement. The properties which they investigated were short-term, 1-day strength; long-term 60 -day strength; water requirements; workability; and shrinkage. This work was done under ERDA Contract No. EC-77-C-02-4269.

Through the use of a simple physical model, the PCA has attempted to understand the nature of the chemistry and crystal structure of the hardened paste. The model explains the effects of changing particle-size distribution as being due, in large part, to surface-to-volume ratios and surface water film thicknesses, mass transport in the water-filled interstices between cement particles, and physical stacking effects due to spheres of different sizes.

In the proposed Phase II portion of this work, the PCA would seek a better theoretical understanding of the effects of particle-size distribution, and also conduct sufficient product testing to support claims that the CPSD cements are, in fact, superior in use to normal cements.

The findings to date indicate that $27 \%$ of the product grinding energy per ton, or $9.5 \times 10^{12}$ Btu's per year can be saved in the production of CPSD cement (PCA, 1979). Furthermore, the PCA anticipates an additional savings of $8.5 \%$ of the industry energy consumption due to the use of less cement per cubic yard of concrete, or an additional saving of $37 \times 10^{12}$ Btu's per year (PCA, 1979). Total potential energy saving thus are $46.5 \times 10^{12}$ Btu per year.

The future needs for research and development concerning CPSD cements include: (1) improved understanding of the theory of size effects on physical properties, and (2) demonstration of the improved performance of concrete made with CPSD cement. The first need will benefit the eventual optimization of a CPSD cement size 
distribution. The latter is essential before CPSD cement will be accepted by the standards-setting organizations and the construction industry. The program which the PCA has laid out in its proposal (dated August 1979) appears to address these issues adequately. The cost of that program should be as proposed; i.e., approximately $\$ 200,000$, plus an approximately $10-15 \%$ factor for inflation, (or, in toto, $\$ 220,000$ $\$ 230,000$ in late 1980$)$.

The PCA has mentioned a third phase which would involve the design, construction, and operation of a pilot plant for the production of CPSD cement. This phase would yield design data on CPSD cement equipment in addition to providing enough CPSD cement for some large-scale testing. Phase III is likely to cost $\$ 1-2$ million, including engineering, purchase of equipment, operating personnel, technical support and evaluation, preparation and testing of samples, and limited field testing and surveillance. Depending on the degree of demonstration, total program costs (Government and private sector) could amount to $\$ 10$ million.

The Federal Government can encourage the development and use of CPSD cement in three ways.

- Supporting basic research and further development;

- Providing investment tax credits or grants to partially offset the cost of equipment and research; and

- Specifying or allowing the use of CPSD cements in Federal projects to demonstrate that concrete made from CPSD cement is comparable or better and that it is as easy to use. Government use of CPSD cement also provides a known buyer of this cement which will help a producer make his decision to install this technolugy.

\section{Low-alkali Cement}

Uñdèr the generic description of "low-alkali cement," the PCA has investigated two novel techniques for removal of the deleterious sodium and potassium oxides. The process removes them directly from the portion of the feed materials in which they appear prior to feeding to the kiln rather than from the ground and mixed feed in the kiln. 'l'he two perceived advantages of the techniques would be the removal of alkali from a smaller amount of material and the wasting of less product after it has passed through the kiln.*

Alkali metal compounds (salts and oxides of sodium and potassium) are undesirable for two reasons:

- These compounds tend to concentrate in the kiln and build up sticky deposits on the inside of the equipment, and

- The alkali components react with certain reactive aggregates in concrete causing structural weakness.

\footnotetext{
- The alkali content of cement is controlled by removing a purge stream of the fraction of kiln product which is richest in the alkali compounds.
} 
The problem of alkali/aggregate reactions is minimized by maintaining alkali levels at $0.6 \%$ by weight or less (expressed as $\mathrm{Na}_{2} \mathrm{O}$ ). The various standards-setting bodies have defined that cement with less than $0.6 \%$ alkali as "low-alkali" cement and can be so specified for projects which use reactive aggregate.

Since the sodium and potassium are natural constituents of one or more of the raw materials at many plants, some means of monitoring and controlling the alkali content is now employed. It has long been recognized that the alkalis are relatively volatile at temperatures in the range of $1832^{\circ} \mathrm{F}$. It is this relative volatility which creates the observed concentration of alkali in the kiln, since the alkalis are vaporized as the kiln material heats to $1832^{\circ} \mathrm{F}$, carried with the kiln gases to a cooler part of the kiln, and deposited on the cooler feed or kiln walls. Normal practice is to purge a portion or all of the gas stream, which is rich in alkali, to control the alkali content of the final product and to maintain the recycle concentration at a level which does not cause physical build-ups on the interior of the equipment.

This is accomplished in traditional wet and dry kiln by disposal of some or all of the dust which is collected from the kiln exhaust gas. In modern preheat or preheater/precalciner kiln, a portion of the hot kiln exhaust gas is removed (by-passed) before the preheater or precalciner to control alkali. Dust which is removed from the exhaust gases after the preheater is typically recycled.

Two techniques which were proposed and studied by the PCA under DOE Contract No. EM-78-C-4929 involved the removal of the alkali compounds appearing in typical clays. The first technique-a "low" temperature one-attempted to vaporize the alkalis at $1652-2012^{\circ} \mathrm{F}$ under various conditions. Ultimately, although the technique successfully lowers the alkali content of the clay, the PCA determined that this process would not be economically feasible because of the large capital requirements for the equipment.

The second technique-a "high"-temperature one-removes the alkalis by preferential absorption in one of two immiscible layers of fused minerals. The PCA observed that the alkalis could be concentrated in a lighter calcium sulfate slag layer, leaving the layer of heavier alumino silioates partially depleted of alkalis. This project was primarily abandoned because no furnace refractory system which would have an acceptable lifetime under the appropriate conditions of temperature, chemistry, and atmosphere has as yet been designed.

The PCA is developing new concepts that might reduce the energy required to produce cement by minimizing the losses associated with alkali removal. These concepts have not as yet been sufficiently developed to propose them to the DOE or other potential sponsors.

Novel techniques for reducing energy waste associated with an alkali purge may offer a potential to save up to $5 \%$ of the kiln fuel or $20 \times 10^{12}$ Btu's per year.*

- Inis estimate is based on the elimination of the practles of disposing of coment kiln dust (estimated to be $5 \%$ of clinker production) as a waste byproduct. 


\section{BIBLIOGRAPHY}

"Cement Report: Annual Financial Reports Round-up" Pit \& Quarry, July 1980, pp. 127-172.

“ENR Materials Prices,” Engineering News Record, May 8, 1980.

1977 Census of Manufactures, U.S. Department of Commerce, (\#MC77-SR-4LP), June, 1979.

Portland Cement Assoc., "Energy Conservation Potential of Portland Cement Particle Size Distribution Control," ERDA Contract No. EC-77-C-02-4269, March 1979. 


\section{GLASS INDUSTRY}

\section{Industry Overview}

The U.S. glass manufacturing industry can be viewed as being composed of five segments, based on technology, products, and markets. The four major segments are flat glass, container glass, pressed and blown glass, and glass fibers. The fifth segment consists of products of purchased glass. This latter segment is not an integrated glassproducing segment, since glass is not melted but only finishing operations are carried out. Compared to the four major segments, the products from the purchased glass segment are low consumers of energy and will not be considered in this study. Handmade glassware manufacturing is also excluded from the analysis.

Approximately 400 glass manufacturing plants are operating in the United States. The industry employs an estimated 15,000 people. The largest single segment is glass container manufacturing, which probably accounts for $60 \%$ of the glass tonnage produced in this country. Of the total value of products, glass containers represent $51 \%$; wool and textile fiber, $18 \%$; pressed and blown ware, $17 \%$; and flat glass, $14 \%$.

In general, the companies in the glass industry participate in one or perhaps two segments, but rarely does a single company participated broadly in more than two segments. In the flat glass and fiberglass sectors, the U.S. industry is concentrated in relatively few firms with seven companies dominating the former, and three companies producing $80-90 \%$ of the fiberglass. The concentration is less intensive in the glass container industry, although the 8 largest of the 30 firms in this sector probably produce $75-80 \%$ of the product.

Since the markets for the industry are broad and very diverse, generalizing on industry growth is difficult. Flat-glass shipments are heavily dependent on the automotive and construction industry, while some pressed and blown ware are more closely tied to consumer spending for television, lighting, and household goods. Wool fiberglass markets are dominated by construction, both residential and commercial, while textile fibers are used in products for the marine, automotive, and construction business. The container glass market is highly influenced by the beverage market where glass competes with aluminum and steel.

The future growth in the total glass industry is expected to continue at much the same rate as it has historically grown in the past, i.e., slightly less than that of the GNP. The bulk of the glass produced in the United States is concentrated in the East North Central, Middle Atlantic, and Pacific regions. The major glass-producing states are Illinois, Ohio, Pennsylvania. New York, West Virginia, New Jersey, and California.

There are differences in the pattern of energy used within each sector, but natural gas is the predominant fuel used to melt glass, and melting is the major energyconsuming step in the entire glass manufacturing process. Melting accounts for about $70 \%$ of the total volume of energy consumed in glassmaking. 
In recent years, the glass industry has been consuming nearly 0.4 quad of energy per year, about $70 \%$ of which is natural gas and $20 \%$ electricity; the balance consists largely of fuel oils. There have been no major shifts in fuel-consuming patterns in recent years.

\section{Conventional Glass Manufacturing Process}

Although the glass industry produces a large number of different products and serves quite different end-use markets, there are common features in the production process. Schematically, the process is shown in Figure IV-2. The major unit process may be viewed as follows:

- Raw materials, handling, and batch preparation;

- Melting;

- Refining;

- Forming;

- Finishing.

The first three process steps - batch preparation, melting, and refining - are quite similar throughout the glass industry, although refining may differ in degree in processes used to make different products, such as flat glass, where optical homogeneity is extremely important, and fiberglass, where optical properties are not critical. Batch preparation is not a significant energy-consuming process step. However, melting of the raw materials to form a viscous glass melt consumes approximately $70-75 \%$ of the total energy used in glass production. The refining step, which accomplishes the homogenization of the melt, accounts for approximately 5 $10 \%$, and forming and finishing, principally annealing, for $15 \%$ of the total energy used in glass production. The remaining energy is consumed in ancillary equipment. Melting and refining are carried out in the large continuous furnace, and it is this process step that will obviously. receive the greatest attention in attempts to conserve energy through process change.

\section{Glassmaking/Pelletizing-Batch Preheating}

\section{a. Description}

Present glassmaking practice consists of heating powdered raw materials from room temperature to melting temperatures in a glass tank. About one third of the raw materials undergo a decompositional change which requires an additional energy input to the energy required to take these materials from room temperature to the melting temperaturc. Pelletizing the raw material batch and then heating these pellets by utilizing the waste gases from the melter will effect an energy saving.

Figure IV-3 is a schematic representation of a pelletizing-batch preheating system. Basically, the system consists of taking a weighed and mixed glass batch formulation (these operations could be done using present equipment) and conveying weighed amounts to a feeder which, in turn, feeds a disc pelletizer. The disc pelletizer takes the powdered feed material, to which about $12 \%$ water has been added, and transforms 


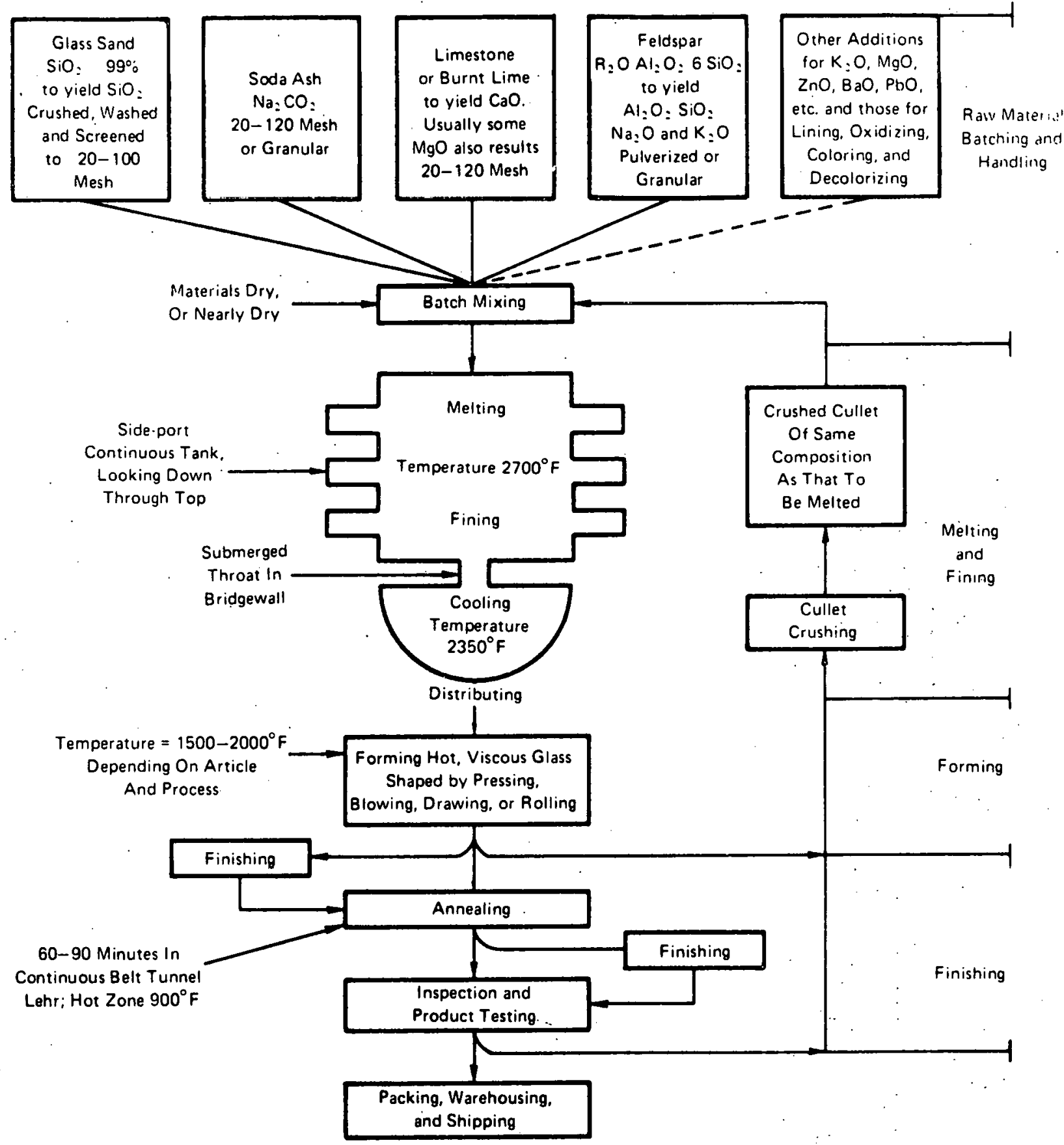

FIGURE IV-2 CONVENTIONAL PROCESS FOR MANUFACTURING GLASS 


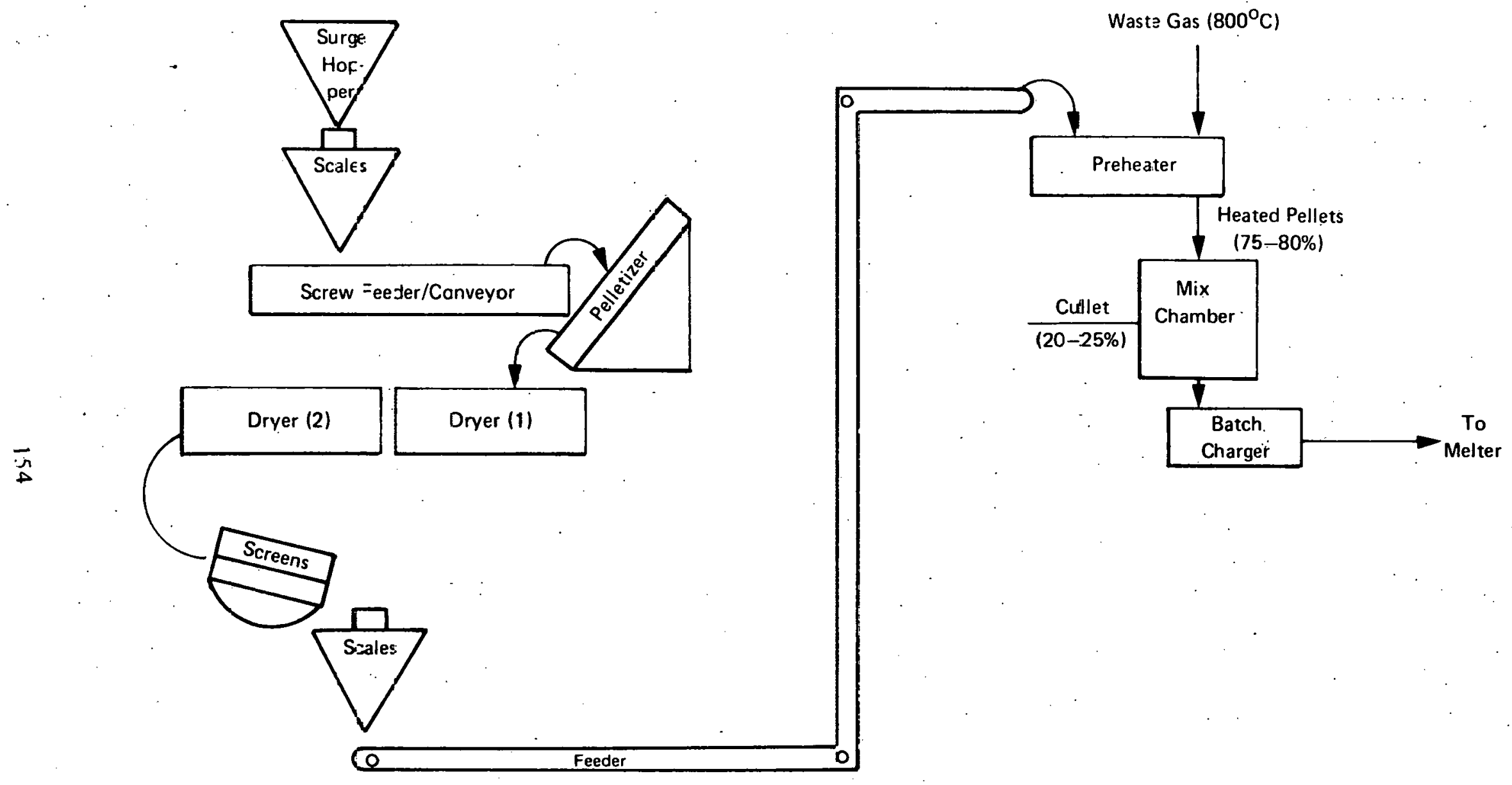

FIGURE IV-3 SCHEMATIC OF PELLETIZING AND BATCH PREHEATING SYSTEM

音 
this mix into pellets. From the pelletizer the pellets are conveyed to a dryer(s) to remove the $12 \%$ water. Present design (Miller, ${ }^{*} 1979$ ) calls for a two-step drying cycle, the first step of which would remove about $25 \%$ of the water and the second step the remaining $75 \%$. It is anticipated that this two-step drying operation will yield a stronger dried pellet.

Subsequent to the drying operation, the pellets are screened to remove fines and then fed to the preheater. The preheater utilizes waste heat from the melter to heat the pellets. To accomplish this, a recuperator installed in conjunction with the glass melter, provides hot gas, at about $1472^{\circ} \mathrm{F}$, to the preheater. At this temperature the pellets are still in a non-stick condition, yet much of the low temperature-endothermic decomposition has already taken place. As the cooled stack gases pass through the bed of pellets, a good deal of the particulate emissions normally associated with glass melting is trapped in the bed. This saving in emission will be in addition to the anticipated emission reductions due to pelletizing itself.

Upon exiting the preheater, the hot pellets are mixed with cullet (about $20-25 \%$ cullet) in a chamber and then metered-conveyed to the melter.

\section{b. Potential for Energy Saving}

Before one can estimate the potential energy saving of pelletizing-batch preheating in the glass industry, essentially three different parameters must be established. One is the total energy consumed by the glass industry. A reasonable measure of this quantity may be obtained from the Government Census of Manufactures by summarizing the various energy forms consumed by the different types of glass manufacturers, i.e., container, flat, fiber, and the like. Of the total energy consumed about $70 \%$ is for melting. Therefore, the total energy consumed for glass melting is in the order of 0.3 quad per year at recent consumption levels.

Tha second parameter required for calculating energy saving is the potential reduction in melting energy due to conversion to pelletizing-batch preheating. Based upon laboratory experiments (Miller, ${ }^{*} 1979$; Williams, ${ }^{* *} 1979$ ), a figure of $28 \%$ has been indicated. It should be noted that this figure of $28 \%$ is not only due to the recovery of waste heat-batch preheating, but also includes a reduction in melting energy due to an increase in pull rates from the melter. To better understand this point, the following is included:

Consider, first, the case of a melter which contains glass at its "melting temperature," but in which glass is neither being fed nor removed. Energy is being lost through the refractory walls and floor and also up the stack. These losses are inherent in a melter (although affected by melter size and age) and are independent of pull rate. If one assumes that refractory losses are about $10 \times 10^{\circ}$ Btu's per hour and stack losses are about $5 \times 10^{\circ}$ Btu's per hour, then these losses total about $360 \times 10^{\circ}$ Btu's per day. For a furnace typically producing 120 tons per day, this would mean an energy loss of $3 \times 10^{8}$ Btu's ton of glass pulled. If, however, the furnace output is increased, as is anticipated by pelletizing and batch preheating to 200 tons per day, then this energy loss would be reduced to $1.8 \times 10^{\circ} \mathrm{Btu}$ 's per ton, or a net saving of $1.2 \times 10^{\circ}$ Btu's per ton. 
In addition to the above energy requirement, as raw/powdered batch is fed to the melter and glass is pulled, additional energy or heat must be supplied to melt the batch. In so doing, additional stack losses occur. These losses amount to about $2 \times 10^{\circ}$ Btu's per ton and to a first approximation are independent of pull rate. This heat is, however, recoverable and, as such, is the basis of batch preheating. The energy required for melting is also about $2 \times 10^{\circ}$ Btu's per ton.

Without heat recovery, a 120-ton per day furnace would then consume about:

$3 \times 10^{8}$ Btu's per ton (Furnace Losses) $+2 \times 10^{6}$ Btu's per ton (Melting Energy) + $2 \times 10^{8}$ Btu's per ton (Additional Stack Losses) $=7 \times 10^{8}$ Btu's per ton;

with heat recovery and increased output:

$1.8 \times 10^{6}$ Btu's per ton (Furnace Losses) $+2 \times 10^{6}$ Btu's per ton (Melting Energy) + $1.2 \times 10^{8}$ Btu's per ton (Additional Stack Losses) $=5 \times 10^{\circ}$ Btu's per ton.

Thus, percent net saving would be:

$$
100 \times(7-5)\left(10^{6}\right) / 7 \times 10^{8}=28.6 \%
$$

It would appear that the $28 \%$ net saving indicated by laboratory tests is a reasonable value. Hence, if the total glass industry converted to batch preheating and the additionally produced tonnage could be sold, or conversely, if increased pull rates per furnace reduced the number of furnaces, then a total saving of

$$
0.3 \text { quad per year } \times 0.28=0.08 \text { quad per year }
$$

would be realized.

However, it does not appear reasonable to assume that all production would convert to pelletizing-batch preheating. Some facilities may be space limited; hence the equipment would simply not fit, or the output at some facilities would not justify the capital expenditure; i.e., $\$ 2-3$ million (Miller, 1979, Williams, 1979) for this system. It is this last parameter, industry conversion ratio, which greatly affects the calculation for determining the net energy saving for this process, as it could vary between 0 and $100 \%$ or a saving of 0 to 0.08 quad per year. The other two parameters are not expected to change much. The total energy consumed per ton should remain near recent levels due to offsetting effects. Total glass tonnages are increasing, but as furnaces are rebuilt and better insulation is used, a reduction in energy consumption per ton will occur. Also, the $28 \%$ process-related saving is consistent with both calculated values and laboratory experiments.

\footnotetext{
- Miller, R., private communication, Corning Glass Works, Corning, N.Y., September 1979.

*Williams, M.L., private communication, Surface Dlv., Midland-Ross Corp., Toledo, Ohio, September 1979.
} 


\section{c. Present Status of Development}

In both this country and Europe, a form of batch preheating has been utilized, but only on a laboratory scale. Pilot-plant facilities in the United States are planned but are contingent upon funding of proposals. Although such a system has not been implemented, the individual pieces of equipment are familiar to industry participants.

\section{d. $R \& D$ Needs and Development Costs}

Utilization of this technology will require confirmation of the calculated energy savings. At this time, neither the technical nor economic feasibility has been demonstrated. It appears as if the capital cost and demonstration program may be in the order of $\$ 4$ to $\$ 6$ million; however, this would have to be confirmed after the technical feasibility has been demonstrated.

Whether existing glass plants could implement this technology, once it is determined feasible, would depend on specific plant situations. Space limitations may make it difficult to alter the in-line process, and plant output, if sufficiently small, may not justify such an expenditure.

\section{e. Role of the Federal Government}

To implement this technology, the Federal Government could consider providing support to the glass industry to build a pilot plant facility to demonstrate its feasibility at a production level which could be scaled to typical production levels. Also, one must be cognizant that this technology would not only provide an energy saving, but would also decrease pollution emissions.

\section{BIBLIOGRAPHY}

Battelle Columbus Laboratories, "Energy Use Patterns in Metallurgical and Nonmetallic Mineral Processing - Phase IV: - Energy Data and Flow Sheets, High Priority Commodities," PB 245 759, June 1975.

Battelle Columbus Laboratories, "Industrial Energy Study of the Glass Industry," PB 242 832, December 1975.

Dow Chemical Company, "Energy Consumption: Paper, Stone/Clay/Glass, Concrete, and Food Industries, PB 241 926, April 1975.

Gordian Associates, "The Potential for Energy Conservation in Nine Selected Industries - The Data Base," 1975.

Arthur D. Little, Inc., Industrial Environmental Research Laboratory, "Environmental Considerations of Selected Energy Conserving Manufacturing Process Options." XI, Glass Industry Report, U.S. Environmental Protection Agency, Report No. EPA 600/7-76-0341, December 1976. 


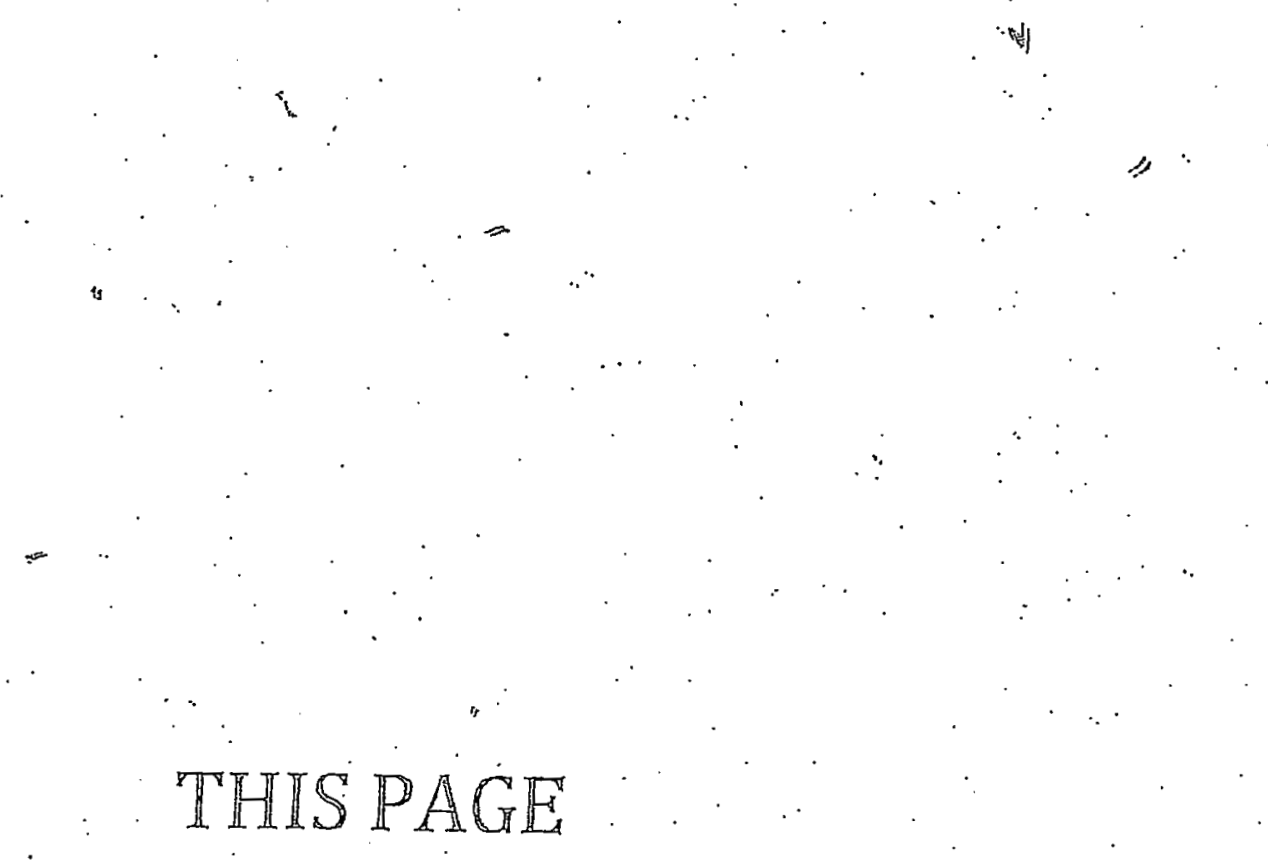

WAS INTENTIONALLY

LEFT BLANK 


\section{APPENDIX POTENTIAL ENERGY-SAVING TECHNOLOGIES}

Table A-1 contains a summary of general concepts and related specific technologies in the high-temperature sector not examined elsewhere in this report. In addition to estimates of potential for energy conservation, Table A-1 shows the current status of the technology and, wherever possible, provides estimates of the relative cost to implement the new technology, as well as a comments column.

\section{BIBLIOGRAPHY}

Arthur D. Little, Inc.,"Research, Development, and Demonstration for Energy Conservation," SAN/1962-1, pp. I-3,5,6 (January 1978).

Arthur D. Little, Inc., "State-of-the-Art Review Computer Control in the Steel Industry," submitted to DOE (June 1979).

Arthur D. Little, Inc., "Environmental Considerations of Selected Energy Conserving Manufacturing Process Options, 10 report for EPA 600/7-76-034 (December 1976). 


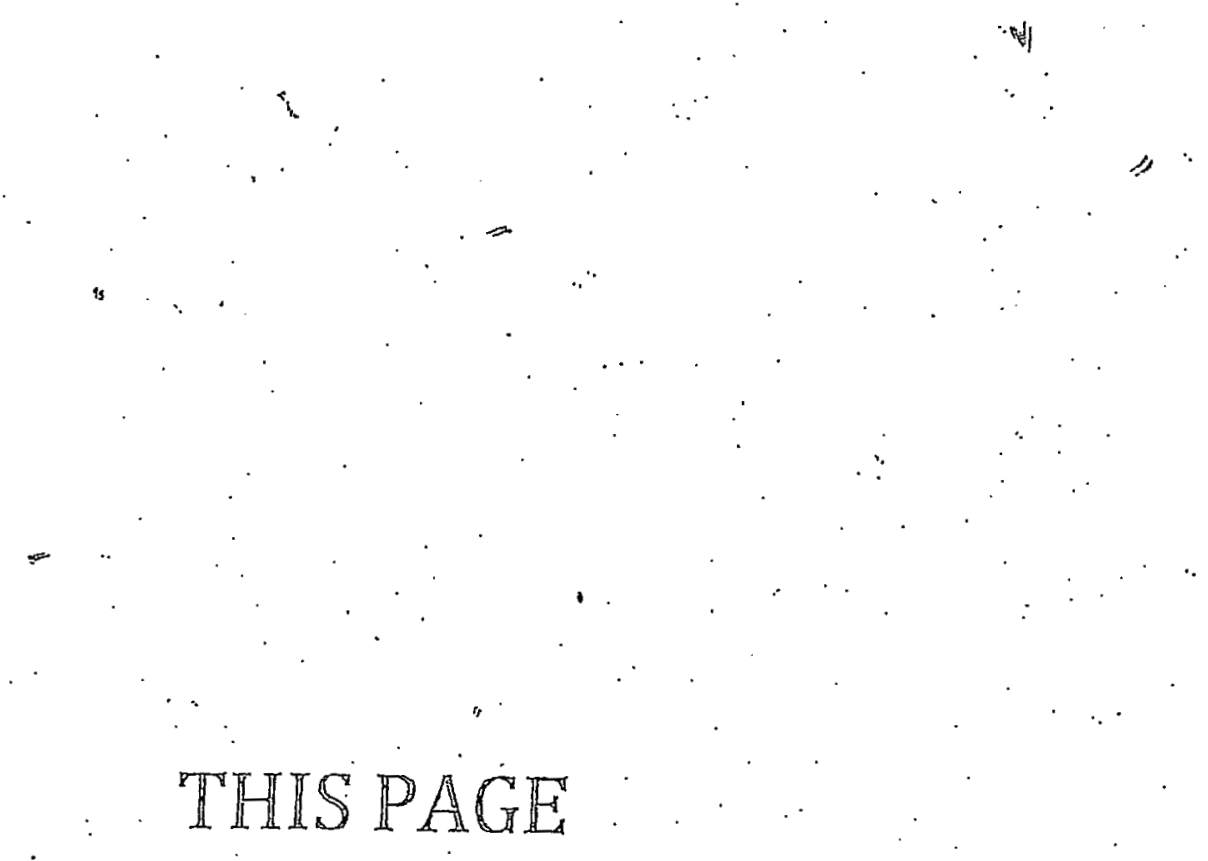

WAS INTENTIONALLY

LEFT BLANK 
TABLE A-1

\section{EXAMPLES OF OTHER ENERGY-SAVING TECHNOLOGIES}

\section{Sector}

Iron and Steel

Industry

$\begin{array}{ll}\begin{array}{l}\text { Area of Process } \\ \text { Refinement }\end{array} & \begin{array}{c}\text { Examples of Energy- } \\ \text { Saving Technology }\end{array} \\ \text { Reheating } & \begin{array}{l}\text { Better heat recuperation } \\ \text { in steel reheating furnaces }\end{array}\end{array}$

Reheating

Reheating

Reheating

Increasing scrap

use (preheating

technologies)

Coal-based

gasifier/burner

Agglomeration

Furnace using direct coal firing rather than gas or oil

Computer control of reheat furnaces

Waste heat recovery

in annealing

Scrap preheating for electric arc furnaces

New coal burner

\section{Potential \\ Energy \\ Saving \\ Development$$
\text { Cost }
$$ \\ (SMillions)}

C

C

\footnotetext{
Conversion from naturà gas or fuel oil to coal in pelletizing plants
}

$15-25$

$15-50$

1.40

\section{Comments}

Reasonable to moderate extrapolation of currently available technology required (ADL, '78)

Engineering problems on coal ash need to be resolved prior to implementation (ADL, '78)

Demonstrated abroad (ADL, '79)

Reasonable to moderate extrapolation of currently available technology required (ADL, '78)

Good engineering concept needed (ADL, '78)

Sulfur and ash removal needed from hot gas stream (ADL, "78)

Technology established and being demonstrated (ADL, '78) 
TABLE A-1 (Continued)

\section{Area of Process \\ Sector \\ Iron and Steel \\ Industry (cont'd.) \\ Refinement \\ Comminution \\ (grinding of iron \\ ore)}

ล
Lime marufacture

Improvement of

high-temper ature

materials

Improvement of

plant energy

management

Cogeneration

Steel Casting

Ladle prefheating
Examples of Energy-

Saving Technology

Improvement in particle

classification

Dxygen use in lime kilns: preheating of limestone

Recuperators, regenerators skids for reheating furnaces

Sentralized computer control of energy managenent and production scheduling

Use of waste heat in bottoming cycles

Continuous casting method, casting larger varieties of steel grades

More efficient ladle preheater

\section{Potential \\ Energy \\ Saving}

C

C

C-B

C-B

B-A

C
Development

Cost

(SMillions)

\section{Comments}

$0.1-10$

Small improvements over time (ADL, '78)

Most applications would be outside of the steel industry (ADL, '78)

Small improvements over time (ADL, 78)

Energy saving depends on specifically adopted policies: computer optimization is not always acceptable to management/labor plans (ADL. '79)

Extent in use of $25 \cdot \mathrm{Hz}$ power needs to be determined

Some technical advancements required before full potential is realized (ADL, "78)

Logistical and engineering problems exist (ADL, '78) 
TABLE A-1 (Continued)

\section{Sector}

Iron and Steel

Industry (cont'd:)

Aluminum Industry
Soaking pits/reheat

\begin{tabular}{|c|c|c|c|c|}
\hline $\begin{array}{l}\text { Area of Process } \\
\text { Refinement }\end{array}$ & $\begin{array}{l}\text { Examples of Energy- } \\
\text { Saving Technology }\end{array}$ & $\begin{array}{l}\text { Potential } \\
\text { Energy } \\
\text { Saving }\end{array}$ & $\begin{array}{l}\text { Development } \\
\text { Cost } \\
\text { (\$Millions) }\end{array}$ & Comments \\
\hline $\begin{array}{l}\text { Soaking pits/reheat } \\
\text { furnaces }\end{array}$ & $\begin{array}{l}\text { Induction heating of } \\
\text { slabs }\end{array}$ & B-A & $0.1-10$ & $\begin{array}{l}\text { Technology established, fuel } \\
\text { oil, natural gas savings } \\
\text { (ADL, '78) }\end{array}$ \\
\hline Alumina manufacture & Flash casting process & * & * & \\
\hline Alumina manufacture & Heat Management & * & * & $\begin{array}{l}\text { Reduce heat loss in existing } \\
\text { equipment and increase *. } \\
\text { product yield per pass which } \\
\text { improves the efficiency of } \\
\text { energy use }\end{array}$ \\
\hline Reduction of alumina & Alcoa chloride process & $A$ & $50-500$ & $\begin{array}{l}\text { More efficient than Hall- } \\
\text { Heroult cells currently in } \\
\text { use (ADL, '76) }\end{array}$ \\
\hline Reduction of al.smina & Alcan subhalide process & $*$ & * & $\begin{array}{l}\text { Involves smelting of bauxite } \\
\text { in an electric arc furnace to } \\
\text { an Al-Fe-Si alloy, and subse- } \\
\text { quent treatment with } \mathrm{AlCl}_{3}\end{array}$ \\
\hline Reduction of alumina & $\begin{array}{l}\text { Pechiney carbothermic } \\
\text { and nitride process }\end{array}$ & * & . & $\begin{array}{l}\text { Involves the thermal production, } \\
\text { and subsequent high-temperature } \\
\text { decomposition of aluminum } \\
\text { carbide or nitride }\end{array}$ \\
\hline Extrusion & $\begin{array}{l}\text { Reduce scrap } \\
\text { generation }\end{array}$ & * & * & $\begin{array}{l}\text { Improves yield, thereby im- } \\
\text { proving the efficiency of } \\
\text { energy use }\end{array}$ \\
\hline
\end{tabular}


TAELE A-1 (Continued)

\section{Sector}

Area of Pricess

Refinement

Aluminum Industry

(cont'd.)

Refining

Refining

Extrusion

Preheating

Cement Industry

\section{Examples of Energy. Sawing Teḉnology}

Perticle solicification

rhe casting

Improved resovery in autımobile shredding

Electric heating of billets

Suspension preheater

B-A

Flash calciner

B-A

$1-10$

B
$1: 10$

\section{Devslopment}

Cost

(\$raillions)

$1 \cdot 100$

$1-10$

\section{0}

Lower process energy requirements, primarily due to significantly lower fuel energy (ADL, '76)

Industry is adopting preheating as a result of higher energy prices.

Lower process energy require. ments primarily due to insignificantly lower fuel energy (ADL, '76) 
TABLE A-1 (Continued)

\begin{tabular}{|c|c|c|c|c|c|}
\hline ector & $\begin{array}{l}\text { Area of Process } \\
\text { Refinement }\end{array}$ & $\begin{array}{l}\text { Examples of Energy- } \\
\text { Saving Technology }\end{array}$ & $\begin{array}{c}\text { Potential } \\
\text { Energy } \\
\text { Saving }\end{array}$ & $\begin{array}{l}\text { Development } \\
\text { Cost } \\
\text { (\$Millions) }\end{array}$ & Comments \\
\hline $\begin{array}{l}\text { Cement Industry } \\
\text { (cont'd.) }\end{array}$ & Cement manufacture & Fluidized bed & B.A & $1-20$ & $\begin{array}{l}\text { Lower process energy due to } \\
\text { generation of total electrical } \\
\text { energy requirements from } \\
\text { reactor exit gases (ADL, } 76 \text { ) }\end{array}$ \\
\hline · & Fuel conversion & Coal fuel & A & See comment & $\begin{array}{l}\text { Energy conservation due to use } \\
\text { of coal as opposed to natural } \\
\text { gas and oil for heat energy: } \\
\text { industry rapidiy adopting } \\
\text { (ADL, '76) }\end{array}$ \\
\hline Glass Industry & Glass melting & Electric melting & * & $*$ & $\begin{array}{l}\text { Greatiy reduced energy con- } \\
\text { sumption for pollution control, } \\
\text { process has relatively greater } \\
\text { operating costs (ADL, '76) }\end{array}$ \\
\hline
\end{tabular}

\section{Symbols}

A - 50-500 trillion B1u's per year conservation potential (either Btu's or oil/natural gas)

B - 5.50 trillion Btu's per year conservation potential (either Btu's or oil/natural gas)

C - 0.5-5 trillian Btu's per year conservation potential (either Btu's or oil/natural gas) Information to be developed 